\title{
12. SEDIMENT COARSE FRACTIONS FROM THE WESTERN INDIAN OCEAN AND THE GULF OF ADEN (DEEP SEA DRILLING PROJECT LEG 24)
}

\author{
Jörn Thiede, ${ }^{1}$ Geologisk Institutt, Avd. B, Universitetet i Bergen, Olaf Ryesvei 19, N-5014 Bergen, Norway
}

\begin{abstract}
Hemipelagic sediments in the Gulf of Aden, pelagic deep-water deposits in the Somali Basin and pelagic shallow-water sequences in the central Indian Ocean were penetrated and recovered during Leg 24 of the Deep Sea Drilling Project. The coarse fractions from these sediments have been studied. They have provided evidence that the Gulf of Aden has existed at least since middle Miocene as an ocean basin with typical hemipelagic sediments (high total sedimentation rates, high terrigenous input, high contents of organic carbon, high sedimentation rates of calcareous nannoplankton and planktonic foraminifera, high proportion of benthic fossils, abundant fish remains) suggesting its water masses to have been very fertile. The region had an arid climate during Miocene and Pleistocene times, while it seems to have been less dry during Pliocene (plant debris). An elevated ridge crest not accessible to coarse sediment components from both sides of the gulf had already been developed in the Miocene. The region now occupied by the $>5000$-meter-deep Alula-Fartak Trench which offsets Sheba Ridge seems to have been passable for sediment transport from the Arabian side of the gulf to the southeast during Pliocene. Upper Cretaceous deposits above the Somali Basin basement east of Chain Ridge are already true pelagic sediments. The preservation of calcareous sediment components of both deep Somali Basin sites suggests that a large portion has been replaced from areas of shallower water depths. Pliocene sediments east of Chain Ridge contain shallow-water-derived components which may have come either from the Gulf of Aden or from an area northeast of Carlsberg Ridge. The central Indian Ocean sites contain early Tertiary to Quaternary pelagic oozes and chalks. The sediments of all three sites are pertinent to the equatorial high production belt thus precluding major geographic readjustments of that piece of oceanic crust in a north-south direction since early Tertiary. The degree of fragmentation of planktonic foraminifera offers a useful tool for determining paleodepth although these sites were nearly always well above the calcium carbonate compensation depth. This is important for the interpretation of vertical sea-floor movements in connection with shifts of the spreading centers. The pattern of preservation of planktonic foraminifera also shows that a high proportion of the recovered sediments are displaced. This is substantiated by the joint occurrence of well-preserved planktonic foraminifera and true shallow-water-derived components in coarse-grained horizons in a matrix of poorly preserved calcareous oozes.
\end{abstract}

\section{INTRODUCTION}

During Leg 24 of D/V Glomar Challenger in the northwest Indian Ocean and Gulf of Aden, holes were drilled at eight sites covering the following major physiographic provinces (Figure 1 and Table 1):

1) Site 231-Gulf of Aden, close to the continental margin of Somalia;

\footnotetext{
${ }^{1}$ Present address: School of Oceanography, Oregon State University, Corvallis, Oregon 97331.
}

2) Sites 232 and 233-Gulf of Aden, on either side of the Alula-Fartak Trench, an apparent transform fault;

3) Sites 234 and 235-Somali Basin on either side of the Chain Ridge, a supposed continuation of Owen Fracture Zone;

4) Site 236-north of the Seychelles Bank, one of the Indian Ocean microcontinents;

5) Site 237-on the saddle of the Mascarene Plateau between Seychelles Bank and Saya de Malha; and

6) Site 238-east of the Central Indian Ridge, within the filled eastern end of the Argo Fracture Zone. 




Figure 1. Location of DSDP Leg 24 drill sites in the Western Indian Ocean and Gulf of Aden. 
TABLE 1

Station List of Samples Used in this Report

\begin{tabular}{|c|c|c|c|c|}
\hline Hole & Latitude & Longitude & $\begin{array}{l}\text { Water } \\
\text { Depth } \\
\text { (m) }\end{array}$ & $\begin{array}{l}\text { Penetration } \\
\text { (m) }\end{array}$ \\
\hline \multicolumn{5}{|l|}{ DSDP Sites } \\
\hline $\begin{array}{l}231 \\
232 \\
232 \mathrm{~A}\end{array}$ & $\begin{array}{l}11^{\circ} 53.41^{\prime} \mathrm{N} \\
14^{\circ} 28.93^{\prime} \mathrm{N}\end{array}$ & $\begin{array}{l}48^{\circ} 14.71^{\prime} \mathrm{E} \\
51^{\circ} 54.87^{\prime} \mathrm{E}\end{array}$ & $\begin{array}{l}2161 \\
1758\end{array}$ & $\begin{array}{l}584 \\
434\end{array}$ \\
\hline & $14^{\circ} 19.68^{\prime} \mathrm{N}$ & $52^{\circ} 08.11^{\prime} \mathrm{E}$ & 1860 & 271 \\
\hline $\begin{array}{l}234 \\
234 \mathrm{~A}\end{array}$ & $04^{\circ} 28.96^{\prime} \mathrm{N}$ & $51^{\circ} 13.48^{\prime} \mathrm{E}$ & 4738 & 247 \\
\hline 235 & $03^{\circ} 14.06^{\prime} \mathrm{N}$ & $52^{\circ} 41.64^{\prime} \mathrm{E}$ & 5146 & 684 \\
\hline 236 & $01^{\circ} 40.62^{\prime} \mathrm{S}$ & $57^{\circ} 38.85^{\prime} \mathrm{E}$ & 4504 & 328 \\
\hline 237 & $07^{\circ} 04.99^{\prime} \mathrm{S}$ & $58^{\circ} 07.48^{\prime} \mathrm{E}$ & 1640 & 694 \\
\hline 238 & $11^{\circ} 09.21^{\prime} \mathrm{S}$ & $70^{\circ} 31.56^{\prime} \mathrm{E}$ & 2844 & 587 \\
\hline \multicolumn{5}{|c|}{ ANTIPODE Cores } \\
\hline ANTP $120 \mathrm{P}$ & $11^{\circ} 08.4^{\prime} \mathrm{S}$ & $70^{\circ} 31.4^{\prime} \mathrm{E}$ & 2827 & \multirow{4}{*}{$\begin{array}{l}\text { close to } \\
\text { DSDP } 238 \\
\text { close to } \\
\text { DSDP } 237 \\
\text { close to } \\
\text { DSDP 237 } \\
\text { close to } \\
\text { DSDP 236 }\end{array}$} \\
\hline ANTP $142 \mathrm{P}$ & $10^{\circ} 16.5^{\prime} \mathrm{S}$ & $58^{\circ} 58.0^{\prime} \mathrm{E}$ & 2763 & \\
\hline ANTP 146P & $7^{\circ} 02.4^{\prime} \mathrm{S}$ & $58^{\circ} 09.9^{\prime} \mathrm{E}$ & 1638 & \\
\hline ANTP $150 \mathrm{P}$ & $1^{\circ} 39.6^{\prime} \mathrm{S}$ & $57^{\circ} 35.3^{\prime} \mathrm{E}$ & 4482 & \\
\hline \multicolumn{5}{|c|}{ CHAIN Cores (Cruise 100, Leg 4) } \\
\hline $\mathrm{CHN} 30 \mathrm{P}$ & $04^{\circ} 27.7^{\prime} \mathrm{N}$ & $51^{\circ} 08^{\prime} \mathrm{E}$ & 5049 & \multirow{2}{*}{$\begin{array}{l}\text { close to } \\
\text { DSDP } 234 \\
\text { close to } \\
\text { DSDP } 235\end{array}$} \\
\hline CHN 32P & $03^{\circ} 14.2^{\prime} \mathrm{N}$ & $52^{\circ} 41^{\prime} \mathrm{E}$ & 5123 & \\
\hline
\end{tabular}

Geographically the sites span an area of $25^{\circ}$ of latitude and $22^{\circ}$ of longitude and were drilled in water depths ranging from 1640 to 5146 meters. The sediments recovered from these eight sites range, stratigraphically, from upper Cretaceous to Pleistocene. Oceanic basaltic basement was reached and penetrated at four sites $(231,235,236$, 238 , Fisher et al., 1972). The most striking feature of these sediments is their apparent homogeneity (Figure 2). In the majority of cores they consist of fine-grained calcareous nannofossil ooze and do not show the rich diversity of sedimentary facies known from drill sites in other oceans. However, the lithologic changes are great enough at each site to distinguish several lithologic units, although often on the basis of variations in calcium carbonate content alone. Gross lithology, stratigraphy, and the correlation of the sedimentary sections of Sites 231-238 are shown in Figures 2 and 3.

This study describes the coarse fraction of the sediments of these eight sites. Special emphasis has been given to the preservation of calcareous particles, mainly pteropod and planktonic foraminifera tests.

The study will deal with:

1) Distribution of components at each site;

2) Overall regional sedimentation patterns of single components and groups of components;

3) Discussion of regional aspects including summaries for the Gulf of Aden, the Somali Basin, and pelagic sites in the central Indian Ocean; and

4) General regional aspects.

Although this study is based mainly on coarse fraction analyses (for a detailed description of this method see
Sarnthein, 1971), shipboard smear slide data (Appendix B) and the data provided by the Deep Sea Drilling Project (grain size, organic and total carbon content, and X-ray diffraction analysis) were also used.

\section{METHODS}

All samples for the coarse fraction analysis of Leg 24 sediments were taken onboard Glomar Challenger (except CHAIN 100 and ANTIPODE samples) using the standard sampling procedure of the Deep Sea Drilling Project. The original volume of the samples was usually $10-20 \mathrm{cc}$ and, in a number of $/$ core-catcher samples, somewhat more. The following laboratory procedure was used: drying at about $60^{\circ} \mathrm{C}$, determination of dry weight of total sample, wet sieving using a $63 \mu$ standard sieve, drying at $60^{\circ} \mathrm{C}$, and determination of dry weight of the sand fraction $(>63 \mu$ is here synonymous with coarse fraction). A number of core-catcher samples were sieved through a $163 \mu$ standard sieve. These samples are noted in Appendix A. The data are scanty in parts of some sites because the sediments could not be prepared by this method (in particular sediments at Sites 232, 233, and 237).

An average of about 300 grains per sample were counted using a stereomicroscope with incident light. This is sufficient to obtain a gross picture of the component distribution (ca. 25-30 components differentiated), because the diversity of particles contributing to the coarse fraction is usually rather small.

The various components distinguished in this study are shown in Table 2. 



Material of shells and

test of biogenic components

in coarse fraction



Figure 2. Basic lithology and stratigraphy of DSDP Leg 24 drill sites in the western Indian Ocean and Gulf of Aden. The zonation follows Berggren (1972). 



\section{DSDP LEG 24}

WESTERN INDIAN OCEAN

Q Quaternary UE Upper Eocene

UPL. Upper Pliocene ME Middle Eocene

LPL Lower Pliocene LE Lower Eocene

IM Upper Miocene UPA Upper Paleocen

Miocene lPa Lower Paleocene

un Lower Miocene uc Upper Cretaceous

vo Upper Oligocene

Lo Lower Oligocene

(compare time scale in Berggren, 1972)



\section{จ}

TABLE 2

Occurrence of Various Terrigenous, Authigenic, and Biogenic Components Distinguished in This Study

\begin{tabular}{|c|c|c|c|c|c|}
\hline $\begin{array}{l}\text { Terrigenous } \\
\text { Components } \\
\text { (= Clastic } \\
\text { Grain) }\end{array}$ & $\begin{array}{l}\text { Authigenic } \\
\text { Components }\end{array}$ & $\begin{array}{l}\text { Biogenic } \\
\text { Calcareous } \\
\text { Components } \\
\text { (Plankton } \\
\text { and Mero- } \\
\text { plankton) }\end{array}$ & $\begin{array}{l}\text { Biogenic } \\
\text { Calcareous } \\
\text { Components } \\
\text { (Benthos) }\end{array}$ & $\begin{array}{c}\text { Biogenic } \\
\text { Siliceous } \\
\text { Components }\end{array}$ & $\begin{array}{l}\text { Miscellaneous } \\
\text { Biogenic } \\
\text { Components }\end{array}$ \\
\hline $\begin{array}{l}\text { Quartz } \\
\text { Mica } \\
\text { Feldspar } \\
\text { Heavy } \\
\text { minerals } \\
\text { Dolomite } \\
\text { rhombs } \\
\text { Rock } \\
\text { fragments } \\
\text { Resedimented } \\
\text { fossiliferous } \\
\text { material }\end{array}$ & $\begin{array}{l}\text { Pyrite } \\
\text { Quartz } \\
\text { Glauconite } \\
\text { Zeolite } \\
\text { Gypsum }\end{array}$ & $\begin{array}{l}\text { Planktonic: } \\
\text { Foraminifera } \\
\text { (whole } \\
\text { tests) } \\
\text { Foraminifera } \\
\text { (fragments) } \\
\text { Pteropods } \\
\text { Ostracods } \\
\text { Meroplank- } \\
\text { tonic: } \\
\text { Larvae of } \\
\text { bivalves and } \\
\text { gastropods }\end{array}$ & $\begin{array}{l}\text { Algae } \\
\text { Foraminifera } \\
\text { Bivalves } \\
\text { Gastropods } \\
\text { Bryozoa } \\
\text { Corals } \\
\text { Ostracods } \\
\text { Echinoids }\end{array}$ & $\begin{array}{l}\text { Diatoms } \\
\text { Radiolaria } \\
\text { Sponges }\end{array}$ & $\begin{array}{l}\text { Plants (other) } \\
\text { Hystrichosphaerids } \\
\text { Arenaceous } \\
\text { foraminifera } \\
\text { Fish }\end{array}$ \\
\hline
\end{tabular}

In most samples, only the following components are significant: plant debris, diatoms, Radiolaria, planktonic foraminifera, benthic foraminifera, sponge spicules, pteropods, echinoderms, and fish debris. Only in layers with a high proportion of shallow-water-derived material debris from molluscs, corals, and bryozoans was frequently found. The hemipelagic sediments of the Gulf of Aden and the clays of the Somali Basin contain higher proportions of terrigenous grains (mainly quartz and mica). Authigenic minerals are usually of minor importance in the size fraction studied.

If the coarse fraction of a sample was dominated by one or two components, as is usual in the case of pelagic sediments, their abundance was often estimated with only the minor elements being counted. Detailed studies of foraminifera, ostracods, Radiolaria, and diatoms can be found in specific chapters in this volume.

The following results of these coarse fraction analyses are given in Appendix A:

1) Percentage of sand fraction $(>63 \mu)$ of the total sediment;

2) Proportion of terrigenous, authigenic, and biogenic components in the coarse fractions;

3) Proportion (in the biogenic component group) of tests and shells consisting of the following materials: calcareous, siliceous, and unidentified;

4) Proportion of single components in the total biogenic group; and

5) The following calculated ratios:

a) planktonic foraminifera (whole tests and fragments): Radiolaria

b) planktonic foraminifera (whole tests): fragments of planktonic foraminifera

c) planktonic foraminifera (whole tests): calcareous benthic foraminifera

The smear slide analyses made by the shipboard scientists have been included in Appendix B.

Thin sections from a number of ooze and chalk sediments were prepared. This was done by freeze drying and impregnating the samples (F. Werner, Geological Institute, University of Kiel, Germany).
The proportion of coarse fraction $(>0.063 \mathrm{~mm})$ in all investigated samples of the Leg 24 sediments from the western Indian Ocean and the Gulf of Aden is shown in Figure 4. The textural homogeneity of these sediments is quite striking. In only a few cases did the sediments from the different sites show lithological differences based on textural changes. Based on these observations, three different lithofacies can be defined: (1) Fine-grained sediment with small sand fractions and no sand layers (represented at Sites 231, 232, 233, 234, 235, 237); (2) Fine-grained sediments with small sand fractions, but with isolated sand layers (represented at Sites 231, 232, 233, 234, 235, 236, 238); (3) Coarse sandy sediments in great thickness (not as isolated horizons), represented at Sites 237 and 238. Both, the homogeneous fine-grained and the coarse-grained facies need a sedimentation mechanism continuing unchanged for a certain time, while the fine-grained sediment with intercalated sand horizons require frequent and, because of their sharp boundaries, sudden changes of the sedimentation models, as will be substantiated in the forthcoming pages.

\section{GULF OF ADEN SITES}

\section{Coarse Fractions, Site 231}

Site 231 is located in the inner Gulf of Aden, south of Sheba Ridge (the continuation of the seismically active mid-ocean Carlsberg Ridge into the Gulf of Aden) close to the Somalia continental margin. The area has been mapped in great detail (for example, Laughton et al., 1970). It was known from seismic studies that above a rather smooth basement two sedimentary sequences occurred: the lower one was acoustically transparent, resulting in speculations about a possible evaporite sequence; the upper one was stratified.

The site finally chosen is located about $70 \mathrm{~km}$ north of Somalia, just beyond "magnetic anomaly 5" in 2152 meters of water. It is situated on the southwest portion of a small transform fault which offsets Sheba Ridge. Basaltic basement was reached after penetrating and continuously coring 
231





DSDP LEG 24

GULF OF ADEN

WESTERN INDIAN OCEAN
$\%$ Coarse Fraction $(>0,063 \mathrm{~mm})$



236



237

238 
a 567-meter-thick sedimentary sequence. Correlation between lithology and seismic records was rather good. The transparent deposits consisted of very homogeneous nannofossil oozes (Plate 1), while the sediment above contained numerous sand layers (appearing as stratification in the seismic records). The whole section of hemipelagic sediments ranges stratigraphically from middle Miocene to Pleistocene, giving a minimum age for the basaltic basement.

Five sedimentary units, which become increasingly lithified with depth have been defined. A sixth unit is comprised of basaltic rocks, which contain inclusions of recrystallized nanno chalk, about 13 m.y. old (compare Figures $5 \mathrm{~A}$ and $\mathrm{B}$ ).

The colors of the sediments are grayish-olive, olive-gray, and light olive-gray. The deposits are texturally silty sandy clays or clayey sandy silt. Only a few horizons in upper Miocene to Pleistocene sediments are sands (Figure 6a), from determinations based on smear slide and grain size analyses.

The calcium carbonate content of these sediments ranged from $30 \%$ to $60 \%$, the organic carbon from $0.3 \%$ to $0.9 \% . \mathrm{H}_{2} \mathrm{~S}$ was found nearly throughout the section. X-ray mineralogy determinations showed the presence of calcite, aragonite, dolomite, quartz, K-feldspar, plagioclase, kaolinite, mica, chlorite, montmorillonite, palygorskite, pyrite, and amphibole.

Sedimentary structures are present in zones indicated in Figure 7. They consist either of a combination of texture and color variations (mainly in the upper part of the sedimentary sequence) or only slight changes of hues. Burrowing and mottling were found rather frequently in two zones (Figure 7 and Plate 2) and are otherwise almost absent. Changes of the intensity of burrow mottling in the otherwise homogeneous sediments might be indicative of oxygen content variations in the bottom water. If this is true, then sedimentary structures indicate poorly oxygenated bottom water in this area, particularly during upper Miocene, lower Pliocene, and Pleistocene time.

The coarse-fraction content is rather uniform throughout the sedimentary sequence. Only isolated horizons contain more than $10 \%-15 \%$ of $>0.063 \mathrm{~mm}$ material. These horizons occur more frequently in the upper Pliocene and Pleistocene portion of the section. They are clearly not restricted to the Pleistocene sediment. A purely paleoclimatic (explaining this occurrence as related to Pleistocene eustatic sea-level oscillations) interpretation for the occurrence of shallow-water-derived material in these sand horizons seems therefore insufficient (Figure 8, and Site Report 231). Some of the sandy horizons are volcanic ash (at 170, 179, $203 \mathrm{~m}$ ), especially in Pliocene sediments.

Biogenic and clastic terrigenous components are dominant throughout the entire sedimentary sequence (Figure $6 \mathrm{~b})$, while authigenic particles occur mainly in middle and upper Miocene deposits. The proportions of both groups of components are extremely variable (see Appendix A), and no sharp major boundary was found, but, in general, it can be said that biogenic components become more important in the younger sediments of this site, while terrigenous components form the larger portion of the older part of the section.


Figure 5 (A and B). Sediments directly above basaltic basement at 24-231-63-2-1 (shipboard thin section). The nanno chalks are partly recrystallized, but their biogenic origin is visible due to the presence of recognizable remains of fossils. The origin of the pellet-like structure in (A) is not clear. 




Figure 6a. Clay-silt-sand triangle diagram of Site 231 sediments, based on smear slide analyses. Numbers indicate age of sample.



Figure 6b. Biogenic-clastic-authigenic triangle diagram of Site 231 sediments, based on coarse fraction analyses. 



Figure 6c. Calcareous-siliceous-other shell materiel of fossil tests and skeletons of Site 231 sediments, based on coarse fraction analysis. 




Figure 7. Gross distribution of sedimentary structures and biogenic burrow mottling in Site 231 sediments.

\section{Terrigenous Components}

The distribution of terrigenous clastic coarse-fraction components is given in Table 3. Two different assemblages can be distinguished in the samples at this site.

The first assemblage occurs mainly in the very homogeneous clayey silty nanno oozes and is composed predominantly of quartz, mica, and dolomite rhombs (Figure 9). It is very fine grained (almost entirely in the lowermost size range of the sand fractions) and is usually characterized by small quartz/mica ratios (Figure 10). The quartz grains are mostly angular; however, well-rounded ones are also found. Of special interest are the idiomorph dolomite rhombs which are found rather frequently. Maximum size of these rhombs is about $100 \mu$, and they almost always possess a well-defined milky core inside a clear cover.

The other assemblage occurs mainly in sandy horizons and also contains the above-mentioned three minerals, although the quartz is rounded and polished with diameters up to $1 \mathrm{~mm}$ in size. It also contains additional heavy minerals, rock fragments, fossil detritus, and is characterized by high quartz/mica ratios (see Figures 10 and 11).

The rock fragments consist of the following types:

1) Fossiliferous sandstone and limestone with Recent and fossil larger foraminifera, reworked fossil gastropods, bivalves, bryozoans, glauconite, and dark gray, wellrounded quartzite;

2) Quartzitic fine- and coarse-grained sandstone; and

3) Fine-grained limestone.

They occur frequently in the upper Pliocene and Pleistocene sandy horizons (Table 4 and Figure 11), but were



$231-43-1$

Figure 8. Sediments in the Gulf of Aden. Types of burrowing in upper Miocene sediments of Site 231. Beside the types described on Plate 2 another very thin tube-like type is recognized (24-231-43-1 (128-149).

found not to be restricted to these deposits, as they were also detected in the homogeneous upper Miocene to lower Pliocene sediments (they were not found in middle Miocene 
TABLE 3

Terrigenous Clastic and Authigenic Components in Site 231 Coarse Fractions ${ }^{\mathrm{a}}$

\begin{tabular}{|c|c|c|c|}
\hline Stratigraphy & Terrigenous Components & Authigenic Components & $\begin{array}{l}\text { Quartz/Mica } \\
\text { Ratio }\end{array}$ \\
\hline Pleistocene & $\begin{array}{l}\text { Quartz, mica, feldspar, } \\
\text { heavy minerals, dolo } \\
\text { rhombs, rock fragments, } \\
\begin{array}{l}\text { reworked fossils, volcanic } \\
\text { glass }\end{array}\end{array}$ & $\frac{\text { Pyrite, glauconite }}{\text { (quartz) }}$ & $\begin{array}{l}\text { Compare } \\
\text { Figure } 10\end{array}$ \\
\hline Upper Pliocene & $\begin{array}{l}\text { Quartz, mica, feldspar, } \\
\begin{array}{l}\text { dolo rhombs, rock } \\
\text { fragments, volcanic } \\
\text { glass }\end{array}\end{array}$ & Pyrite, glauconite & \\
\hline Lower Pliocene & $\begin{array}{l}\frac{\text { Quartz, }}{\text { rhombs }}, \frac{\text { mica, }}{\text { heavy }} \text { dolo } \\
\text { minerals, rock frag- } \\
\text { ments, volcanic } \\
\text { glass }\end{array}$ & $\underline{\text { Pyrite, }}$ glauconite & \\
\hline Upper Miocene & $\begin{array}{l}\text { Quartz, mica, feldspar, } \\
\text { dolo rhombs, rock } \\
\text { fragments, volcanic } \\
\text { glass }\end{array}$ & $\begin{array}{l}\text { Pyrite, glauconite, } \\
\text { quartz, (gypsum?) }\end{array}$ & \\
\hline Middle Miocene & $\frac{\text { Quartz }}{\text { rhombs }}, \frac{\text { mica, }}{\text { volcanic glass }} \frac{\text { dolo }}{\text { minerals, }}$ & $\underline{\text { Pyrite, }}$ glauconite & \\
\hline
\end{tabular}

aUnderlined components occur frequently to commonly.



Figure 9. Large fossils found in Pleistocene sediments of Site 231 .

sediments). The preservation of small (diameter ca 1-3 mm) dark gray, rounded, soft clay pebbles in light gray nannofossil ooze in Sample 24-231-43-1, $74 \mathrm{~cm}$ should be mentioned here. The occurrence of shallow-water-derived fossils and fossil fragments in these horizons suggests that the bulk of the sedimentary components was slumped from shallow-water areas on or close to the shelf.

Feldspar and volcanic glass occur throughout the sequence and, although feldspar was expected to occur commonly in these sediments, only a few grains could be identified. Volcanic glass shards were found throughout the entire sequence but occur as a well-defined ash horizon only in Sample 24-231-20-2, $30 \mathrm{~cm}$.

The quartz/mica ratio is highly variable in these sediments (Figure 10). In the stratified part of the sedimentary sequence, where this ratio is always higher in the coarse layers than in the fine-grained nanno ooze, it is indicative of shallow-water-derived material. However, in the older more homogeneous part of this site the quartz/mica ratio was found to be rather variable. It is higher in the older sediments and decreases slowly as sediments become younger. This might indicate broadening of the Gulf of Aden, which was a narrow oceanic appendage in middle Miocene, to an open gulf.

\section{Authigenic Components}

Pyrite and glauconite are the main authigenic components of the Site 231 coarse fraction. Although pyrite is the most common authigenic material, its abundance exceeds $10 \%$ of the total coarse fraction (Figure $6 \mathrm{~b}$ ) only in middle to lower Pliocene deposits. In a number of samples it was found as a replacement mineral of siliceous fossils.

Glauconite usually occurs only as single grains. It is found more frequently in the coarse horizons than in the fine-grained nannofossil oozes. The particles are either globular or of undefined morphology, but in many cases they are still identifiable as fillings of foraminiferal chambers, although none of the foraminiferal carbonate is preserved. Rather fresh-looking benthic and planktonic 




Figure 10. Quartz/mica ratio in Site 231 coarse fractions. Where available, coarse and fine grained sediments were differentiated by signatures. Average values per core.



Figure 11. Occurrence of rock fragments in Site 231 coarse fractions (as number of samples with rock fragments/core) and quartz/mica ratios of the same samples. 
TABLE 4

Occurrence of Rock Fragments in Site 231 Sediments



foraminifera, whose chambers are filled, suggest that the formation of glauconite has continued into Pleistocene times and that the source of it is not exclusively limited to glauconite-bearing Tertiary or Mesozoic strata. Gypsum also occurs in a very few samples. It is suspected to be the result of secondary alteration during sample treatment. This sometimes occurs if the samples are very rich in fine-grained pyrite. Idiomorph quartz crystals are also rare, and it is not clear whether or not they are reworked.

\section{Biogenic Components}

The biogenic components from the coarse fraction at this site are dominantly calcareous. Only six of the investigated samples contain less than $80 \%$ calcareous particles (Figure $6 \mathrm{c}$ ). The distribution of the major fossil group (Figure $6 \mathrm{c}$ ) shows clearly the siliceous components are almost absent in middle Miocene to lower Pleistocene sediments. Essentially they do not appear before the upper Pliocene and reach maximal proportions (never more than $12 \%$ of the biogenic components) in Pleistocene deposits. Components of other than siliceous or calcareous composition occur most frequently during the Miocene, while their proportion diminishes in younger sediments in favor of calcareous particles.

Calcareous plankton found in these sediments consists of planktonic foraminifera, pteropods, gastropod and bivalve larvae, and ostracods. The fragmented shells of pteropods occur frequently in Pleistocene sediments, but are otherwise virtually absent (except in a very few samples younger than middle Miocene). Although they have been found mostly in sandy horizons, they exist also in the intercalated fine-grained nanno oozes; their presence suggests a better calcium carbonate preservation than in pre-Pleistocene sediments. The planktonic foram and pterpod data are summarized in Figures 12 and 13, respectively. The gastropod and bivalve larvae are rare to common in Pleistocene coarse sediments, but are not found in most of the fine-grained nanno oozes.

Benthic calcareous components consist of algal crusts, foraminifera, bivalves and gastropods, coral and bryozoan fragments, ostracods, and echinoid debris. Benthic foram and echinoderm data are tabulated in Figures 14 and 15. Algal crusts are found in upper Pliocene and Pleistocene coarse horizons. Bivalves (mostly fragmented) and more seldom gastropods are components belonging to the suite of shallow-water-derived material. Their scarcity in middle Miocene sediments and their increasing abundance in the younger deposits illustrate the greater input of shallowwater-derived material. Fragments of corals and bryozoans are confined to middle Miocene and Pleistocene samples. Ostracods occur in almost all cores.

Siliceous components consisting of diatoms, Radiolaria, and sponge spicules are tabulated in Figures 16, 17, and 18 respectively.

Hystrichosphaerids and plant debris also occur here. The plant debris reaches a peak of abundance in upper Miocene to Pleistocene sediments.

Arenaceous benthic foraminifera are rare to common in the sediments. The latter is surprising since they usually are not preserved in marine sediments.

Fish remains (both teeth and fragments of bones) occur most frequently in middle Miocene sediments, slowly decreasing in abundance to a minimum in Pleistocene deposits.

\section{Coarse Fractions, Sites 232 and 233}

Sites 232 and 233 are situated to either side of the 5000-meter-deep Alula-Fartak Trench (Laughton et al., 1970) at the mouth of the Gulf of Aden. The Alula-Fartak Trench is a northeast-southwest-trending transform fault offsetting the western continuation of Sheba Ridge toward the southwest. Despite the small distance between these sites, Site 232 supposedly was located over basement older than 10 m.y., while northeast of the crest of Sheba Ridge, Site 233 was located above basement close to "magnetic anomaly 3" (= 5 m.y.). This geologic difference (see Figure 19) was expected to be displayed by differences in the nature of the basement and by the nature of the overlying sediments.

\section{Site 232}

The holes drilled at Site 232 on the northwest flank of the Alula-Fartak Trench underlie 1743 (Hole 232) and 1726 (Hole 232A) meters of water, respectively. After 



Figure 12. Distribution of planktonic foraminifera (whole tests), based on percentages of biogenic components of coarse fractions. Only maximal value of each core is given (compare with Appendix). 
$231 \quad 232-233$



234



\section{DSDP LEG 24 \\ WESTERN INDIAN OCEAN} Occurrence of Pteropods in Coarse Fractions $x$ Trace $(\omega<1 \%)$

Bearing ( 1-10







238



Figure 13. Occurrence of pteropods in Leg 24 coarse fractions (in percent of biogenic coarse fraction components). 





DSDP LEG 24

WESTERN INDIAN OCEAN

of echinoderm debris (maninly spicules)

$x$ Trace $\omega<1 \%$

- Bearing $(\sim 1-10 \%)$


Figure 15. Occurrence of echinoid debris (mostly spicules) of Leg 24 coarse fractions (only highest value is given for each core), based on percentages of biogenic components. 



Figure16. Occurrence of diatoms in Leg 24 biogenic components of coarse fractions (each point indicates abundance in one sample, samples with no diatoms have been omitted). 



- Bearing ( 1-10\%

- Rich ( 10-50\%)

$\triangle$ Abundant $(\sim 50 \%)$

vall 


samples without sponge spicules have been omitted). 




Figure 19. Geological setting of Sites 232 and 233. (A) Sketch map delineating Sheba Ridge and Alula-Fartak Trench (from Laughton et al., 1970); (B) Seismic reflection record (airgun) of Glomar Challenger across the Alula-Fartak Trench close to DSDP sites.

penetration of the sedimentary sequence, "acoustic basement" was reached at a depth of 396.5 meters. The lithology of this horizon is lithified quartzose sandstone $>20$ meters thick of apparent upper Miocene age (Plate 3, Figure 2). The overlying sequence ranges from upper Miocene to Pleistocene in age. The sediments were divided into six different lithologic units based mainly on different proportions of clastic terrigenous components. Of 434 meters of material penetrated, 392 meters consist of nannofossil oozes. The input of clastic terrigenous material reaches a maximum during deposition of silt and sandstone during upper Miocene.

The recovered sediments range texturally from silty clays to sands (Figure 20a), consisting of a diverse assemblage of dominantly terrigenous components (based on X-ray determinations: dolomite, quartz, K-feldspar, plagioclase, kaolinite, mica, chlorite, montmorillonite, palygorskite, amphibole, and calcite). The calcite consists of either biogenic remains or micarb (fine-grained calcareous matter of uncertain origin). Organic carbon contents range from $0.2 \%$ to $1.3 \%$, while calcium carbonate ranges from $5 \%$ to over $60 \%$ in the Quaternary sediments. All the sediments gave off strong odors of $\mathrm{H}_{2} \mathrm{~S}$.

The dusky yellow-green nanno oozes are fairly uniform in color. The silt and sandstone layers are medium to dark gray. As at Site 231, sedimentary structures and burrow mottling are very unevenly distributed. Sedimentary structures are common throughout the whole section except in a few upper Miocene and lower Pliocene cores (Figures 21A to C, Figure 22). Burrows commonly were found only in uppermost Pliocene and Pleistocene deposits, while they are scarce elsewhere in these sediments (Figure 22).

The proportion of coarse fraction is rather small in most samples, reaching higher values only in individual layers. The dominant components are clastic terrigenous grains, particularly in upper Miocene and Pliocene sediments (Figure 20b, Plate 3). With decreasing age, biogenic components become more important and are virtually the only constituents in Pleistocene sediments. Authigenic minerals were found rarely in sediments younger than upper Miocene, where in one sample they reach a maximum of $50 \%$. Pore-water salinities measured onboard and the frequent occurrence of gypsum in the lowermost part of Site 232 may indicate the presence of evaporite-bearing older sediments below the layers sampled.

\section{Site 233}

At Site 233 (1839 m water depth) on the southeastern flank of the Alula-Fartak Trench "acoustic basement" was reached after penetrating 237 meters of sediment. After penetrating a diabase body drilling rates increased, suggesting that this was a sill underlain by sediments. No samples were recovered from below the diabase due to a blocked drill bit. The deposits ranged from upper Pliocene to Pleistocene. Eight lithologic units, based mainly on variations of the micarb proportions, were distinguished.

The recovered sediments are very fine grained (Figure 23a) and belong texturally (based on smear slide analysis) almost exclusively to clays. However, shore-lab grain size determinations have shown that they contain much more silt than determined onboard ship. Organic carbon content ranges from $0.8 \%$ to $2.8 \%$ and the calcium carbonate content between $40 \%$ and $70 \%$. X-ray diffraction determinations show a mineral assemblage similar to that at Site 232. Sedimentary structures are scarce in pre-Pleistocene sediments, but common in Pleistocene deposits (Figure 24). Burrowing and mottling was almost absent except in the uppermost Pliocene and Pleistocene sediments (Figure 22).

To illustrate the nature of the sediments of both Alula-Fartak-Trench sites, micrographs of the smear slides 




Figure 20a. Clay-silt-sand triangle diagram of Site 232, based on smear side analyses.



Figure 20b. Distribution of biogenic-clastic-authigenic components in Site 232 sediments, based on coarse grain anatyses. 




Figure 20c. Composition of tests and skeletons in Site 232 sediments (calcareous, siliceous and other material), based on coarse grain analyses.

of this site are shown in Plates 4 and 5. The smear slide results (see Appendix B of this chapter and Sediment Summary chapter, this volume) as well as the coarse grain analysis showed clearly the decreasing proportion of terrigenous components in the sediments with decreasing age (Figure 23b) in favor of biogenic components. There seems to be an almost complete change from terrigenous upper Pliocene coarse-fraction assemblages to entirely biogenic Pleistocene ones. Authigenic minerals are rare.

\section{Terrigenous Components, Sites 232 and 233}

The terrigenous components of coarse fractions from Sites 232 and 233 are so similar to the coarse-fraction assemblages from Site 231 that very few additional remarks are needed. The occurring particle types are summarized in Table 5. Quartz/mica ratios are highly variable in sediments of both sites despite their apparent homogeneity (Figure 25).

\section{Authigenic Components, Sites 232 and 233}

As at Site 231, pyrite and glauconite are the main authigenic components of these coarse fractions (Table 5). Pyrite is more frequent in the basal part of both sites, but its proportion decreases in the Pleistocene sediments in favor of glauconite. Pyrite is found as a pseudomorph of siliceous fossils in the upper Miocene and lower Pliocene sediments of 232. Gypsum was found rarely in the coarse fractions of both sites presumably being a result of the laboratory processing. However, it occurs more frequently in Miocene sediments at Site 232 than would be expected due to this treatment.

Biogenic Components, Sites 232 and 233

The biogenic components of both sites, like the terrigenous components, are almost identical. The data are plotted in Figures $20 \mathrm{c}$ and $23 \mathrm{c}$ and tabulated in Table 5. Calcareous fossils are dominant at both sites in pre-upper Pliocene and Pleistocene samples. Siliceous fossils formed the major biogenic constituent during upper Pliocene and reach higher proportions in Site 233 than in Site 232 sediments.

Planktonic foraminifera occur abundantly in the sediments of both sites (except in the sandstones of Site 232). Pteropods are confined to upper Miocene and Pleistocene of Site 232 only. Presumably shallow-water-derived biogenic components (bivalves, gastropods) were found dispersed in the sediments of Site 232 (in upper Miocene, lower Pliocene, and uppermost Pleistocene samples). At Site 233, however, they were restricted to upper Pliocene deposits, suggesting a possible source in the northwest or north now being separated off by the Alula-Fartak Trench.

Plant debris is very abundant in uppermost Miocene sediments of Site 232.

\section{SOMALI BASIN SITES}

\section{Coarse Fraction, Site 234 (Western Somali Basin)}

Holes drilled at Site 234 (west of Chain Ridge in the Somali Basin, $4721 \mathrm{~m}$ of water) penetrated sediments from 



Figure 21. Sedimentary structures at Site 232; (A) 24-232-4-6(102-125), Pleistocene nanno ooze with slight color changes, which indicate bedding planes. Some burrows are filled by coarse material; (B) 24-232-7-4(76-99), Pleistocene nanno ooze with distinct layers; (C) 24-232-A-14-1(125-148), upper Miocene silty clay to sandy silt with intercalated quartz sand layers; the main sedimentary components are terrigenous, while plant debris is dominant with the biogenic fraction of the sediment (compare data of coarse fraction analysis).

lower Oligocene to Plio/Pleistocene in age (although major parts of this section could not be dated due to the lack of suitable fossils). The sediments consist dominantly of very fine clays, nanno clays, and oozes which yield only very small coarse fractions except for some horizons in the Plio/Pleistocene and the Oligocene part of the section (Figures $4,26,27)$. The sediments are very homogeneous and sedimentary structures are rare. The few visible ones are mainly due to color changes (Figure 28) and, to a lesser degree, to textural changes. The colors of the sediments are mostly pale green to greenish-gray, olive-gray, and other greenish and bluish hues. Burrows are not abundant but are found in nearly all cores. Often they are visible only because of very fine-grained pyrite coatings.

Organic carbon ranges from $0.2 \%$ to $0.3 \%$; the calcium carbonate content ranges from $0.0 \%$ to $45.0 \%$. X-ray diffraction analyses show the presence of the following minerals: amphibole, calcite, chlorite, dolomite, quartz, K-feldspar, plagioclase, kaolinite, mica, montmorillonite, palygorskite, and pyrite. Montmorillonite reaches a maximum in the deepest sediments at this site. This is presumably the reason for finally forcing abandonment of both holes without reaching basement. Texturally most of the analyzed sediments were clays (Figure 26a).

The recovered cores are divided into six different lithological units as indicated in the site report. These units are predominantly divided on the basis of calcium carbonate content. Although the sediments of this site appear homogeneous, the coarse fractions show a wide variety of components (Figures 26b, 26c, 27). In nearly all samples terrigenous grains are more predominant than at other sites of the open Indian Ocean. Horizons with coarse fractions, which are nearly all terrigenous material, are found at all depths (Figure 26b). Miocene and upper Oligocene sedi- 



233



Figure 22. Gross distribution of sedimentary structures and burrowing/mottling in sediments of Sites 232 and 233.

ments seem to be richer in authigenic components than the Plio/Pleistocene parts of the section. Only rarely does the major part of the coarse fraction consist of biogenic remains (Figure 29A and B).

\section{Terrigenous Components}

The composition of the main terrigenous grain assemblages is indicated in Table 6 . Most of these grains are confined to the $0.063-0.150 \mathrm{~mm}$ size fraction. The following minerals are found: quartz, feldspar, mica, heavy minerals, dolomite rhombs, volcanic glass, and ash fragments. Quartz is the dominant terrigenous component; the grains are always small and mostly angular. Mica is the second most important clastic component, but is always rarer than quartz. The quartz/mica ratios are always $>1$ (maximal values 40 to 100 or more, see Figure 30). The heavy minerals presumably come from the same source as quartz and mica. Most questionable is the origin of the dolomite rhombs, but they characteristically accompany the fine-grained clastic mineral assemblages.

Volcanic glass shards are common constituents of these coarse fractions.

\section{Authigenic Components}

Five different authigenic components occur in the sediments of this site and often reach high proportions. The results are plotted in Figure 26b and tabulated in Table 6. Pyrite is found either in irregular forms, or as molds of fossils (in particular as chamber fillings of planktonic foraminifera). Pyrite pseudomorphs of siliceous fossils, particularly Radiolaria, diatoms, and sponge spicules, are frequently found in Oligocene and middle and upper Miocene sediments. Pyrite does not occur in the same sample as manganese nodule or crests.

Sand-sized, idiomorph, very light zeolite crystals occur frequently as accessory minerals in Oligocene to upper Miocene sediments. In a few cores they occur as distinct sand layers, particularly in Oligocene sediments, which also contain high proportions of montmorillonite. Zeolites seem to be more abundant in zones where virtually all calcium carbonate has been dissolved rather than in calcareous horizons.

Idiomorph quartz crystals occur in Oligocene or middle Miocene sediments, either isolated as single crystals or attached to siliceous fossils, particularly radiolarian skeletons. This indicates a diagenetic origin for these crystals. 




Figure 23a. Clay-silt-sand triangle diagram of Site 233, based on smear slide analyses.



Figure 23b. Distribution of biogenic-clastic-authigenic components in Site 233 sediments, based on coarse grain analyses. 


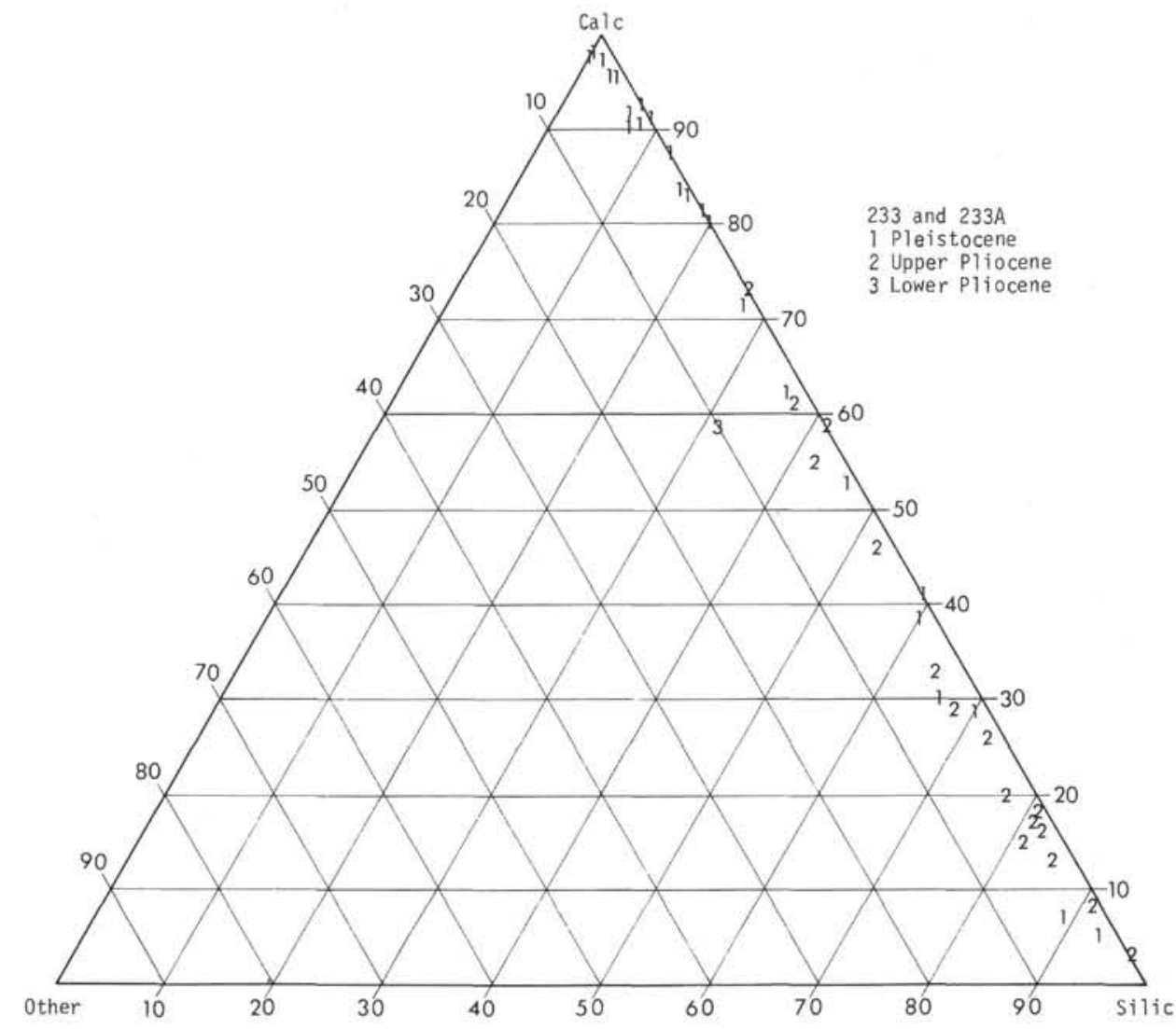

Figure 23c. Composition of tests and skeletons in Site 233 sediments, based on coarse grain analyses.

\section{Biogenic Components}

Biogenic components at this site contain a high proportion of noncalcareous and nonsiliceous fossils (Figures 26c, 27). Except for a few horizons in the Oligocene, Miocene, and the Plio/Pleistocene, calcareous fossils are dissolved. Pyrite pseudomorphs of siliceous fossils are abundant.

Biogenic components rare to abundant in the coarse fractions are calcareous and arenaceous, benthic, and planktonic forams, echinoids, Radiolaria, diatoms, sponge spicules, fish debris, hystrichosphaerids, and plant debris.

Fish debris is abundant at this site, possibly due to dissolution of diluting components, particularly siliceous and calcareous fossils. This is indicated by a high degree of fragmentation of planktonic foraminiferal tests (Figure 29B), a rather small foraminiferal plankton/benthos ratio and pyritization of many siliceous fragments.

\section{Coarse Fractions, Site 235 (Eastern Somali Basin)}

Site 235 is the second site in the Somali Basin. It is situated in about 5100 meters of water, east of Chain Ridge. The objectives at this site were to obtain sediments for comparison with Site 234 sediments, to date the sediments by means of their fossil content, and to attempt to establish a minimum age for the oceanic basaltic basement, which was reached almost 5800 meters below the water surface. Sediments ranging from Upper Creta- ceous to Pleistocene were spot cored and recovered. The sediments consist of dark greenish to yellow-gray nanno oozes and nanno clays.

Sedimentary structures were detected because of slight color changes. Textural changes are visible only in Pleistocene cores. Burrows are very rare (Figure 31 ). Texturally the investigated samples are clays or silty clays (Figure 32 ). The organic carbon content ranges from $0.2 \%$ to $0.7 \%$ and the calcium carbonate content from $2 \%$ to $80 \%$. X-ray analyses show the presence of the following minerals: calcite, dolomite, aragonite, quartz, K-feldspar, plagioclase, kaolinite, mica, montmorillonite, palygorskite, pyrite, phillipsite, and chlorite. This mineral assemblage is very similar to that at Site 234. The high montmorillonite content of the sediments caused difficulty in drilling (particularly in Pleistocene/Pliocene sediments at about 70-140 $\mathrm{m}$ below the sea floor).

Sediments recovered at this site can be divided into three lithologic units as indicated in the site report. Basis for these distinctions were color changes and, like Site 234, changes in the calcium carbonate content. The small amount of coarse fraction found in these fine-grained sediments (Figure 32a and Plate 6) is mostly biogenic in origin (Figure 32b). Clastic and authigenic components are of minor importance in the bulk of the samples. Pliocene and upper Miocene samples seem to be somewhat richer in authigenic components and middle Miocene sediments somewhat richer in terrigenous components. 

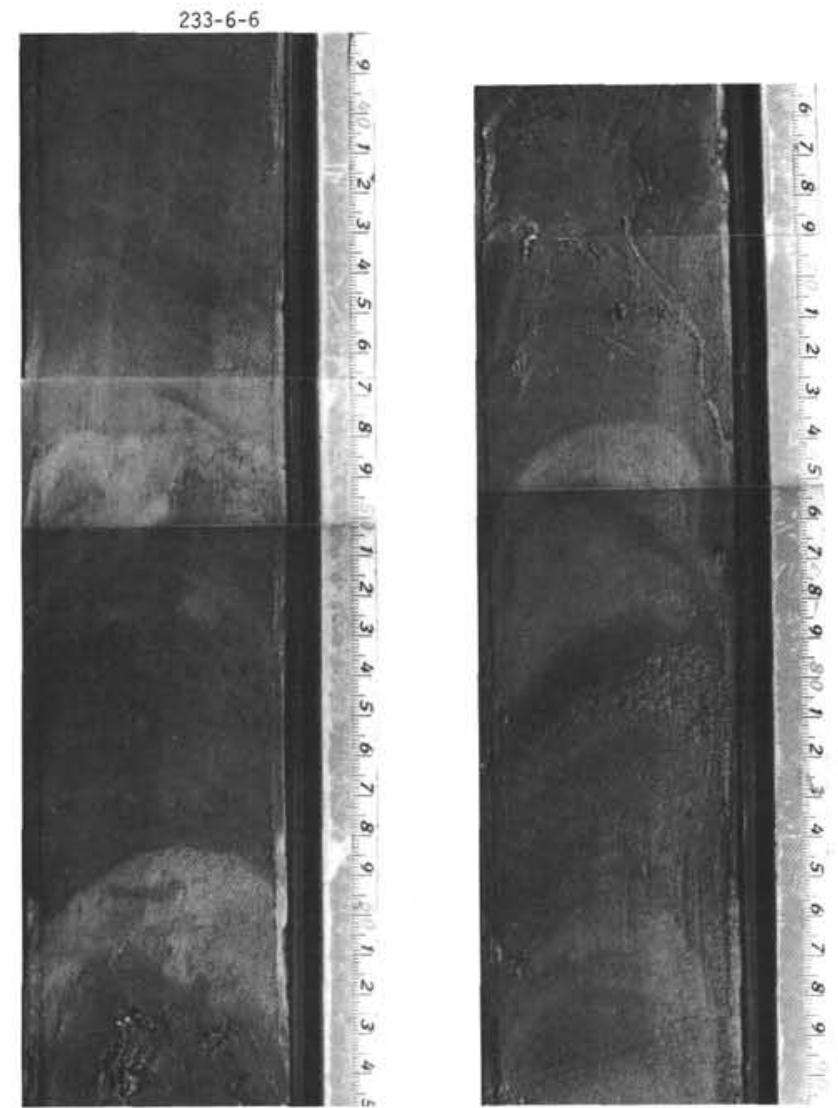

Figure 24. 24-233-6-6, Sedimentary structures in the very homogenous Pleistocene sediments consist mostly of simple color changes, similar to those at Site 232 (compare Figure 21A).

\section{Terrigenous Components}

The terrigenous coarse fractions are found mainly in Miocene sediments. Pliocene deposits contain still fewer clastic grains and Pleistocene sediments almost none. The mineral assemblage is similar to that at Site 234 and consists mainly of mica and quartz. Heavy minerals, dolomite rhombs, and volcanic glass are minor components (Table 7). The quartz/mica ratio is smaller than 1 in surface samples and increases with increasing depth and age to values around 20 in the basal sediments. This is considerably different from the Site 234 sediments where the ratios are much higher (Figure 30). All other terrigenous grains are of minor importance and are scattered throughout the samples. Only colorless volcanic glass was found as a minor constituent in many samples, as at Site 234, indicating a constant but limited volcanic input to these basin sediments.

\section{Authigenic Components}

The authigenic components in the coarse fractions are similar to those at Site 234. They include pyrite, quartz, zeolites, and glauconite and reach highest proportions in Pliocene and middle Miocene sediments (Figure 32b). Manganese nodules and crusts are not found here. Pyrite is the most important authigenic mineral found frequently in nearly all cores, and in many samples is a pseudomorph of siliceous tests, spicules, or fragments. Quartz rarely occurs as isomorph crystals, indicating an authigenic origin for this mineral.

Zeolites and glauconite only occur in the coarse fraction of undated, lowermost Core 16 , which is low in calcium carbonate.

\section{Biogenic Components}

Test and shell materials of Site 235 coarse fractions are shown in Figure 32c. The bulk of the samples contains predominantly siliceous and calcareous fossils. Only a few Pliocene, upper, and middle Miocene samples contain high proportions of other shell material.

The following components contribute to the biogenic assemblages in the coarse fractions: calcareous and arenaceous benthic planktonic foraminifera, rare pteropod fragments, and rare ostracods, echinoid spicules, bivalve debris (occurring in same samples as pteropods), diatoms (mainly in Pliocene and Pleistocene sediment), abundant Radiolaria, sponge spicules, plant debris (most abundant in upper Miocene to lower Pliocene cores) and hystrichosphaerids.

Fish remains are present throughout the whole sedimentary column, reaching highest proportions in Cores 6 , $8,9,10,11,12,13,14,15$, and 16 (base of hole to Pliocene).

\section{CENTRAL INDIAN OCEAN SITES}

\section{Coarse Fractions, Site 236}

This site is situated several hundred kilometers north of Seychelles Bank in 4487 meters of water in the outermost foothills of the Carlsberg Ridge. After penetration of 306 meters of nannofossil oozes, clays, cherts, and chalks (Pleistocene to upper Paleocene in age) basaltic oceanic basement was reached. The possible early Tertiary age of the sea floor based on magnetic anomalies (Fisher et al., 1968) was thus verified. Basement and surface topography roughly follow the strike of Carlsberg Ridge. The sediments encountered were divided into six lithologic units based on changes in calcium carbonate content. The underlying basalts (litho unit 7) also contain inclusions of recrystallized nanno chalks.

The usually rather fine-grained nanno oozes, chalks, and clays, which are yellow-gray to orange and, at the base, dusky brown, contain a great number of coarse-grained horizons suggesting a high proportion of reworked material (Figures 4, 33a). This theory is supported by the frequent occurrence of reworked Eocene, Oligocene, and Miocene micro- and nannofossils in younger sediments.

Primary sedimentary structures occur frequently throughout the whole section (Figure 34), but are often heavily disturbed by drilling and coring. Burrow mottling is very scarce. The calcium carbonate content varies between $0 \%$ and $95 \%$; the organic carbon content ranges between $0.1 \%$ and $0.2 \%$. X-ray diffraction shows the presence of the 
TABLE 5

Occurrence of Terrigenous and Authigenic Components in Coarse Fractions at Sites 232 and $233^{\mathrm{a}}$

\begin{tabular}{|c|c|c|c|c|c|}
\hline \multirow[b]{2}{*}{ Stratigraphy } & \multicolumn{2}{|c|}{ Site 232} & \multicolumn{2}{|c|}{ Site 233} & \multirow[b]{2}{*}{ Quartz/Mica Ratios } \\
\hline & Terrigenous & Authigenic & Terrigenous & Authigenic & \\
\hline Pleistocene & $\begin{array}{l}\text { Quartz, mica, } \\
\text { feldspar, } \\
\text { heavy minerals, } \\
\text { rock fragments } \\
\text { dolo rhombs, } \\
\begin{array}{l}\text { volcanic } \\
\text { glass }\end{array}\end{array}$ & $\frac{\text { Glauconite, }}{\text { pyrite }}$ & $\begin{array}{l}\text { Quartz, mica, } \\
\text { feldspar, } \\
\text { heavy minerals, } \\
\text { dolo rhombs } \\
\text { volcanic } \\
\text { glass }\end{array}$ & $\begin{array}{l}\text { Glauconite, } \\
\text { pyrite, } \\
\text { (gypsum?) }\end{array}$ & $\begin{array}{l}\text { Compare Figures } 1 \\
\text { and } 2\end{array}$ \\
\hline $\begin{array}{l}\text { Upper } \\
\text { Pliocene }\end{array}$ & $\begin{array}{l}\text { Quartz, mica, } \\
\text { heavy minerals, } \\
\text { dolo rhombs, } \\
\text { rock fragments }\end{array}$ & $\begin{array}{l}\text { Pyrite, } \\
\text { glauconite }\end{array}$ & $\begin{array}{l}\text { Quartz, mica, } \\
\text { feldspar, dolo } \\
\text { rhombs, heavy } \\
\text { minerals }\end{array}$ & $\begin{array}{l}\text { Pyrite, } \\
\text { glauconite } \\
\text { (gypsum?) }\end{array}$ & \\
\hline $\begin{array}{l}\text { Lower } \\
\text { Pliocene }\end{array}$ & $\begin{array}{l}\text { Quartz, mica, } \\
\text { heavy minerals, } \\
\text { dolo rhombs, } \\
\text { volcanic glass }\end{array}$ & $\begin{array}{l}\text { Pyrite, } \\
\text { glauconite, } \\
\text { zeolite }\end{array}$ & & & \\
\hline $\begin{array}{l}\text { Upper } \\
\text { Miocene }\end{array}$ & $\begin{array}{l}\text { Quartz, mica } \\
\text { feldspar, } \\
\text { heavy minerals, } \\
\text { dolo rhombs }\end{array}$ & $\begin{array}{l}\text { Pyrite, } \\
\text { glauconite, } \\
\text { zeolite, } \\
\text { gypsum, } \\
\text { (quartz) }\end{array}$ & & & \\
\hline
\end{tabular}

aUnderlined components occur frequently, others only rarely.
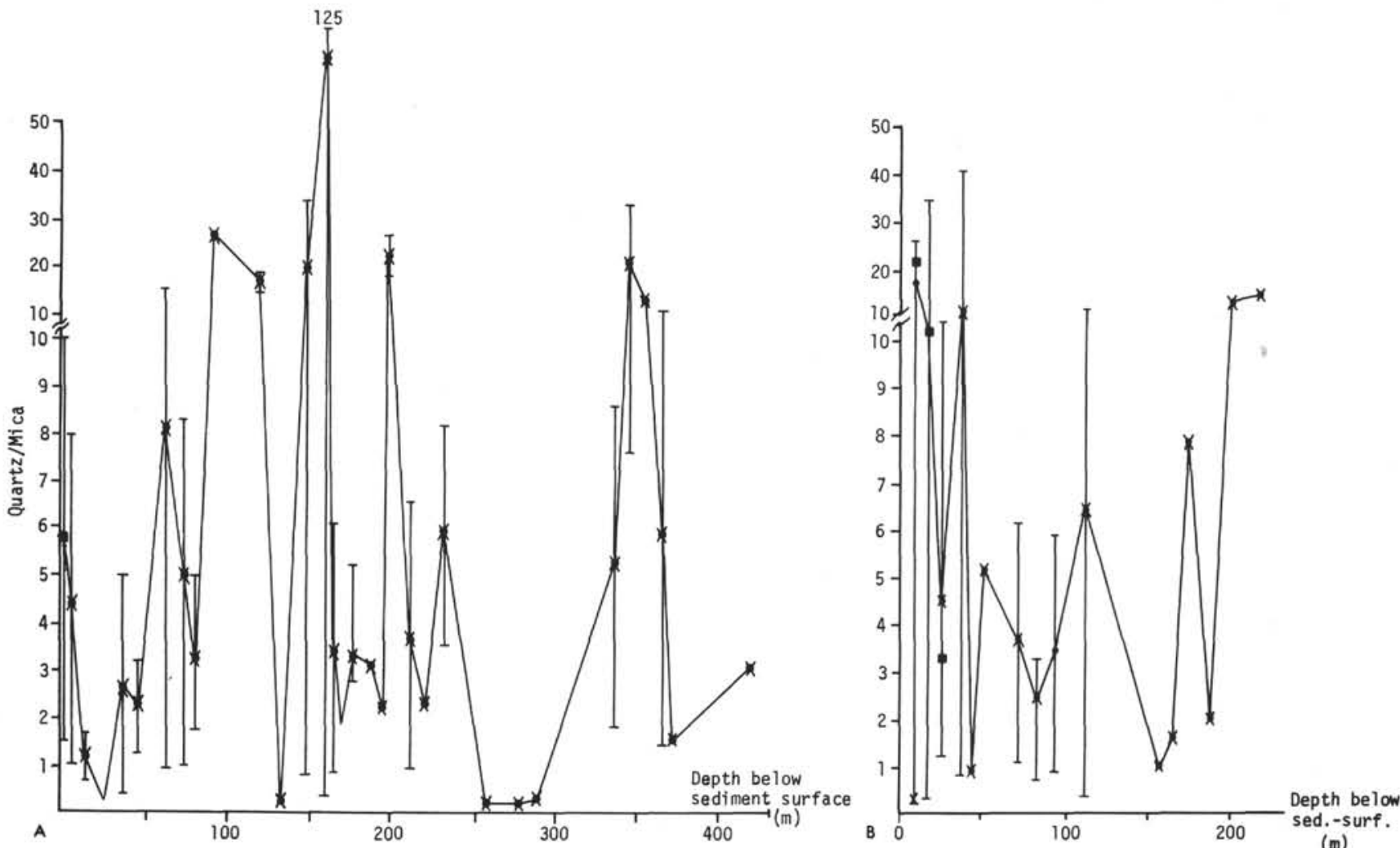

Figure 25. (A) Quartz/mica ratios in Site 232 coarse fractions; (B) Quartz/mica ratios in Site 233 coarse fractions. 


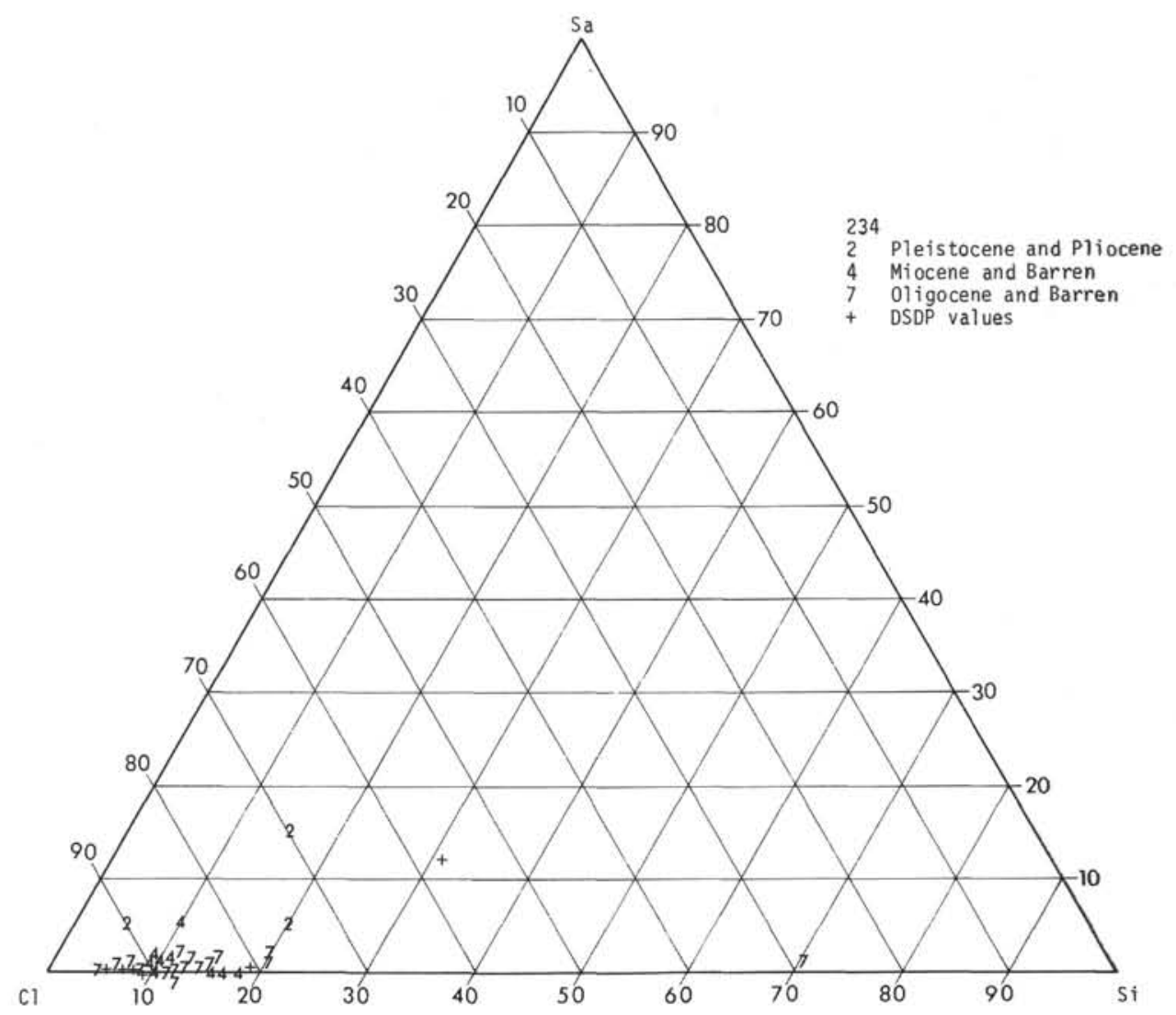

Figure 26a. Clay-silt-sand triangle diagram of Site 234, based on smear slide analyses.

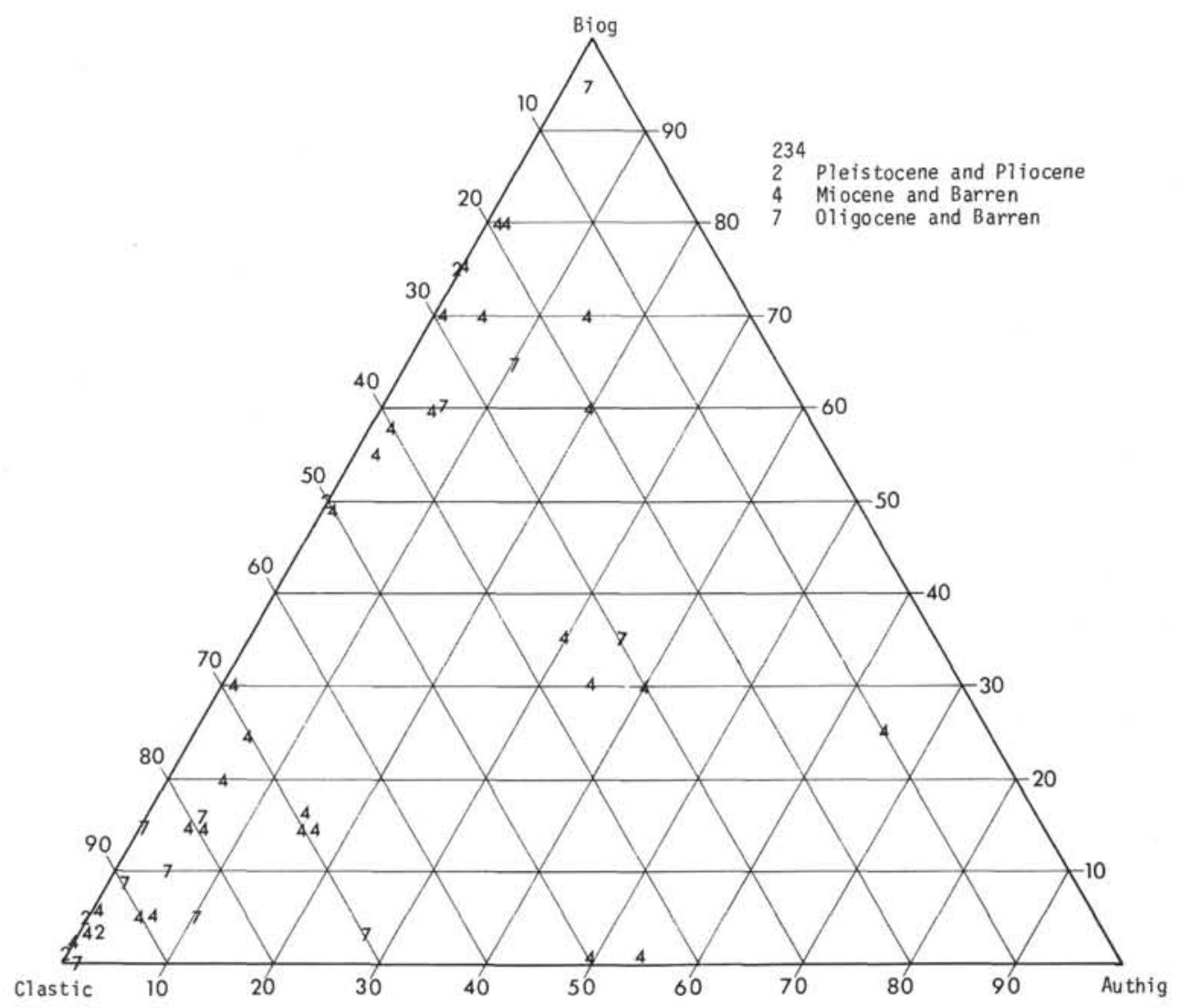

Figure 26b. Distribution of biogenic-clastic-authigenic components in Site 234 sediments, based on coarse grain analyses. 


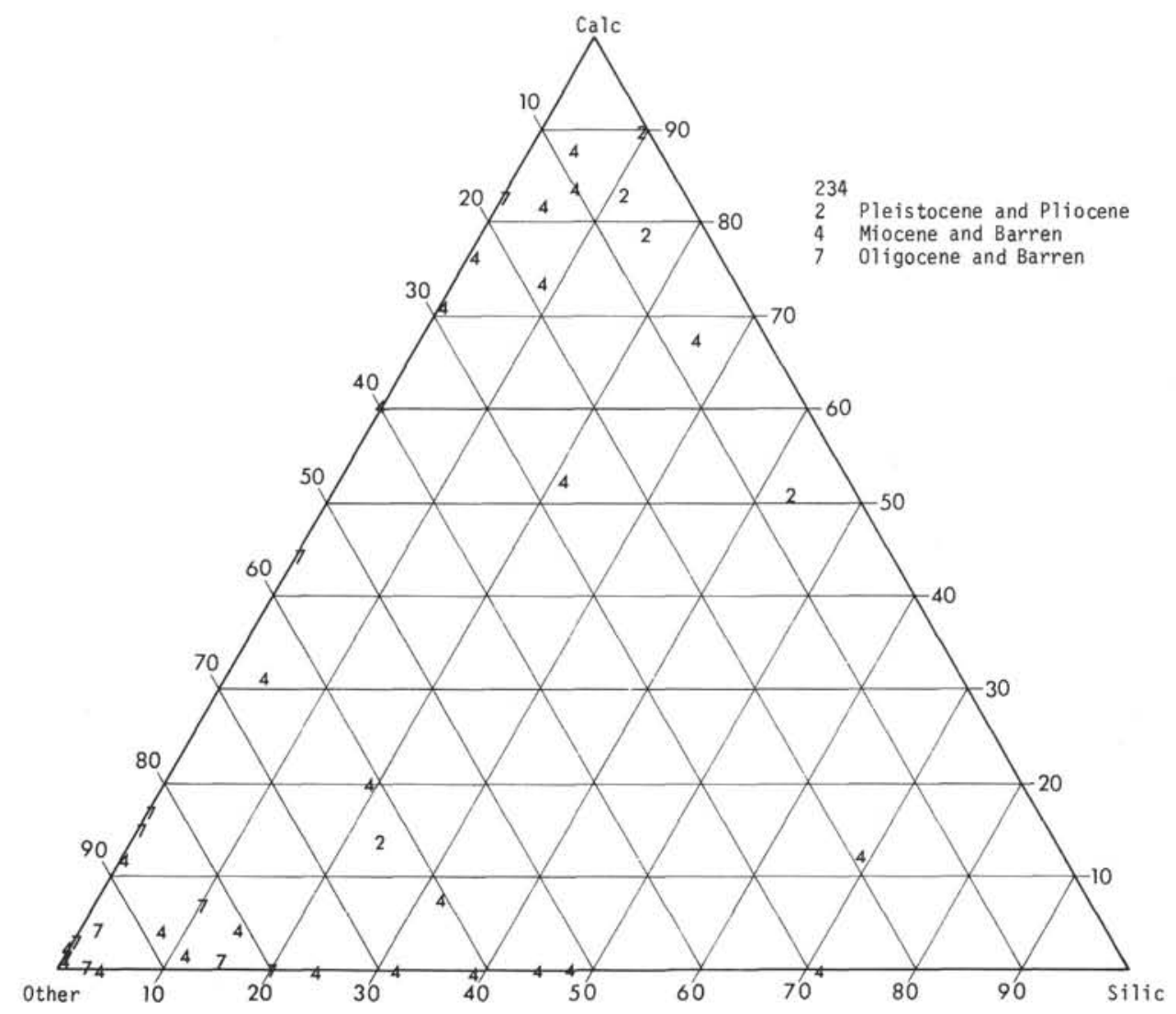

Figure 26c. Composition of tests and skeletons of Site 234 sediments (calcareous, siliceous and other material), based on coarse grain analyses.

following minerals aside from calcite: dolomite, aragonite, K-feldspar, plagioclase, kaolinite, mica, montmorillonite, palygorskite, clinoptilolite, phillipsite analcite, pyrite, barite (gypsum and halite).

The coarse fractions are almost entirely biogenic, with the exception of Miocene sediments.

\section{Terrigenous Components}

The proportion of terrigenous clastic components is small (Figure 33b), and, in the bulk of the samples, less than $1 \%$. Only a few Miocene and Oligocene horizons contained a sizable clastic fraction.

Clastic components are tabulated in Table 8. Quartz is rare and the majority of the grains are small and angular, but in samples with rock fragments somewhat bigger grains are found. Mica is a rare constituent and together with dolomite rhombs and fine-grained quartz might be an eolian contribution to the sediment. Not enough grains were found for a determination of the quartz/mica ratio.

Rock fragments were found in upper Miocene and Pliocene sediments. They are limited to sandy horizons (see Table 9 and Appendix A) and occur together with shallow-water benthic foraminifera. The rock fragments consist of limestone fragments and crystalline, granite-like rocks. The source for these components, all three foreign to a pelagic deep-water environment, may be somewhere very close to Seychelles Bank because there (if no speculation about unknown microcontinents is made) would be the nearest outcrop of continental crust with similar rocks. This would provide an explanation for the limestone fragments and also for the occurrence of shallow-water benthic foraminifera.

Volcanic glass is found mainly in Oligocene and Miocene sediments and usually consists of very light glass particles. Volcanic ashes are indicated in Table 9.

\section{Authigenic Components}

Glauconite, zeolite, and pyrite occur rarely as single grains as indicated in Table 8 . The Miocene and Pliocene glauconite was found mainly in the sandy horizons and might therefore, at least in part, be redeposited.

\section{Biogenic Components}

Calcareous biogenic grains predominate throughout the recovered section (Figure 33c). They consist of forams (benthic and planktonic), rare pteropods, echinoids, algal crusts, fragments of corals, bryozoans, and bivalves (the last four indicative of a shallow-water source. Table 10). Siliceous fossils consist of diatoms (occurring in single horizons in the upper Miocene and lower Oligocene), Radiolaria (frequent only in upper Miocene and upper Eocene to upper Oligocene samples), and sponge spicules whose frequency is correlative with that of the Radiolaria (Figure 35).

Rare plant debris and arenaceous benthic foraminifera also occur along with fish debris, a common component of these sediments. They occur in almost all post-upper Oligocene samples but are rare before. The peak of 


Lithology
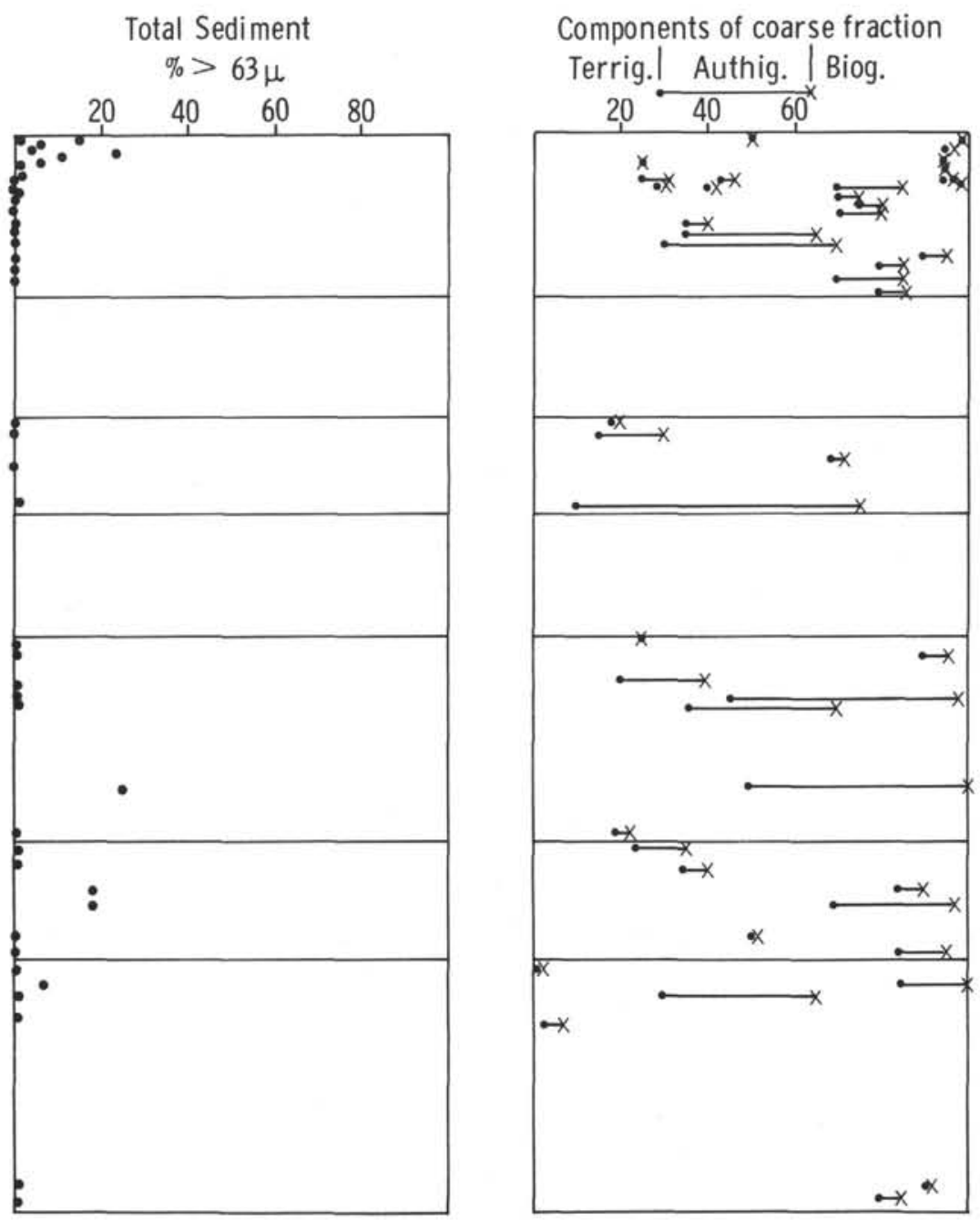

Material of shells and

test of biogenic components

in coarse fraction

Other | Calc. | Silic.

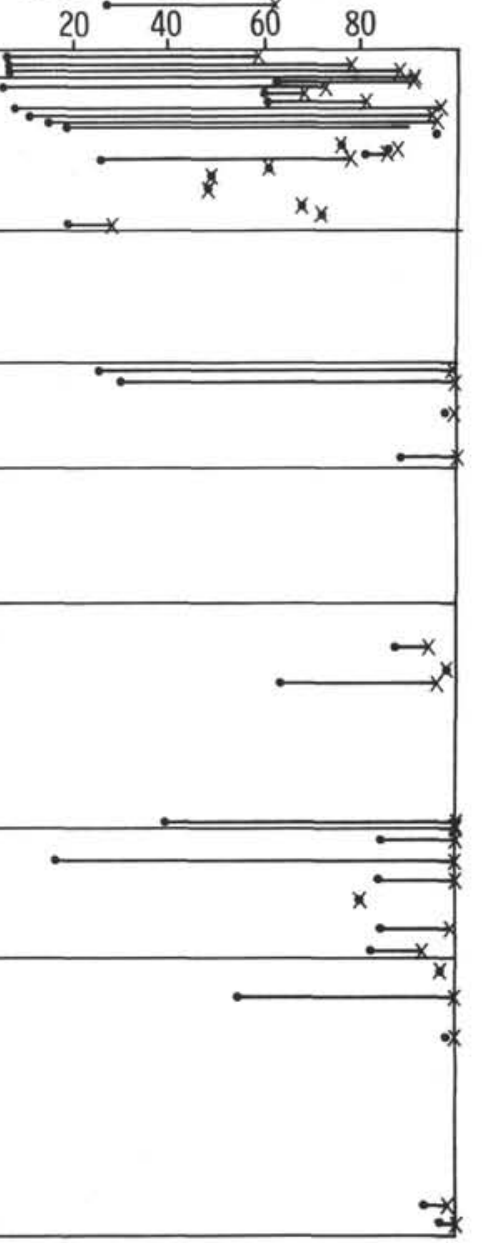

Figure 27. Lithology of Site 234 sediments: gross lithology, percentage of sand fraction in total sediment, main components of coarse fraction, material of shells, and tests of biogenic components. 


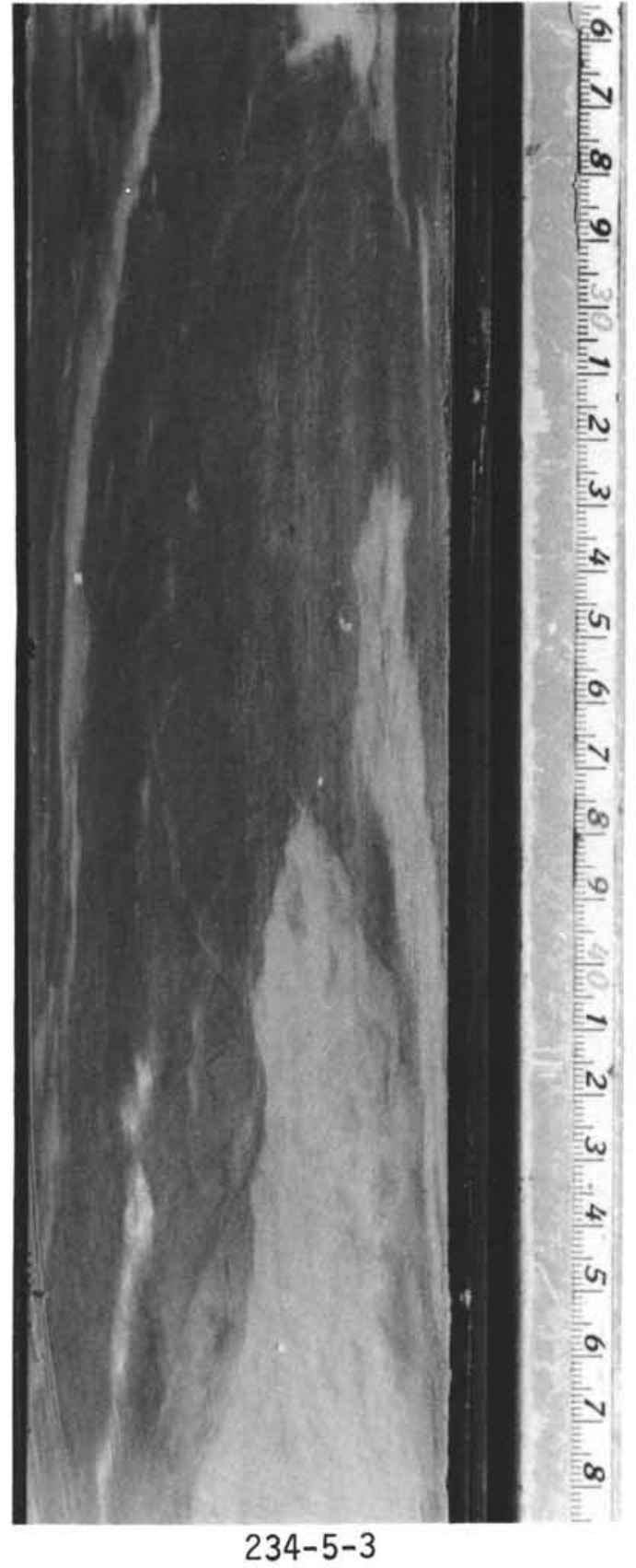

Figure 28. 24-234-5-3(25-48). Lithologic changes in very fine grained middle Miocene. Bedding is disturbed due to drilling/coring process.

abundance of fish debris is during upper to middle Miocene where diluting components are dissolved.

\section{Coarse Fractions, Site 237}

Site 237 is located in 1622 meters of water on the saddle between the Seychelles (granitic basement) and Saya de Malha Bank (basaltic basement according to Shor and Pollard, 1963) in a fault-bounded region of nondescript magnetics (Fisher et al., 1967). Several flat-lying reflectors are visible on available seismic records over the acoustic basement (Bunce et al., 1966).
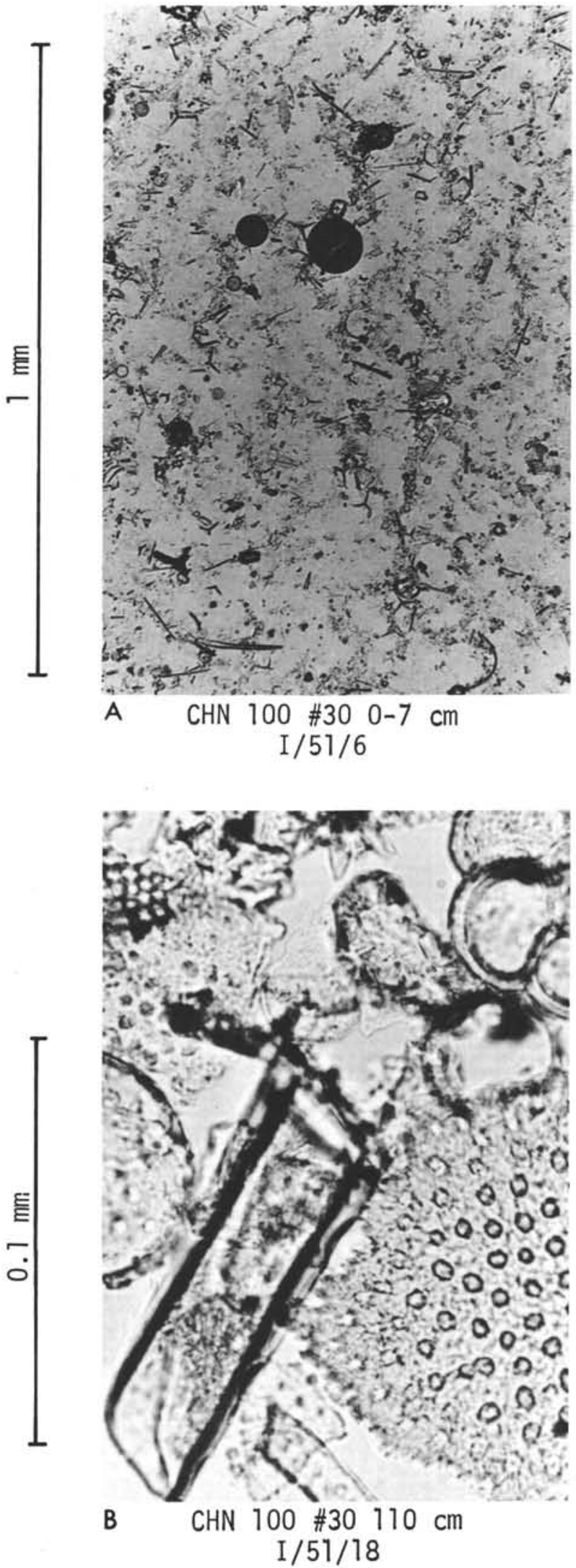

Figure 29. Sediments of CHAIN100/30 (smear slides): (A) surface $(0-7 \mathrm{~cm})$ sediments, mainly consisting of siliceous organic remains; (B) subsurface $(110 \mathrm{~cm})$ sediments with tests and fragments of planktonic foraminifera, radiolaria and a few mineral grains. 
TABLE 6

Composition of Authigenic and Terrigenous Grains

of Coarse Fractions at Site 234

\begin{tabular}{|c|c|c|c|}
\hline Stratigraphy & Terrigenous Grains & Authigenic Grains & Quartz/Mica Ratio ${ }^{b}$ \\
\hline $\begin{array}{l}\text { Plio/ } \\
\text { Pleistocene }\end{array}$ & $\begin{array}{l}\text { Quartz, feldspar, } \\
\text { mica, heavy } \\
\text { minerals, vol- } \\
\text { canic glass, dolo } \\
\text { rhombs }\end{array}$ & $\begin{array}{l}\text { Manganese nodules } \\
\text { glauconite (only } \\
\text { exceptional) }\end{array}$ & $>1$ \\
\hline $\begin{array}{l}\text { Upper } \\
\text { Miocene }\end{array}$ & $\begin{array}{l}\text { Quartz, feldspar, } \\
\text { mica, heavy } \\
\text { minerals, vol- } \\
\text { canic glass and } \\
\text { dolo rhombs }\end{array}$ & $\begin{array}{l}\text { Manganese crusts } \\
\text { (only in upper- } \\
\text { most part), } \\
\text { pyrite, zeolite } \\
\text { (mostly in lower } \\
\text { part of section) }\end{array}$ & $>1$ \\
\hline $\begin{array}{l}\text { Middle } \\
\text { Miocene }\end{array}$ & $\begin{array}{l}\text { Quartz, feldspar, } \\
\text { mica, volcanic } \\
\text { glass, dolo rhombs }\end{array}$ & $\frac{\text { Pyrite, zeolite, }}{\text { quartz }}$ & $>1$ \\
\hline Oligocene & $\begin{array}{l}\text { Quartz, feldspar, } \\
\text { mica, heavy } \\
\text { minerals, dolo } \\
\text { rhombs, volcanic } \\
\text { glass }\end{array}$ & $\frac{\text { Pyrite, zeolite, }}{\text { quartz }}$ & $>1$ \\
\hline
\end{tabular}

\footnotetext{
aMost frequent mineral grains have been underlined. Others appear in samples only as accessoric components.

baximum values 40 to 100 .
}
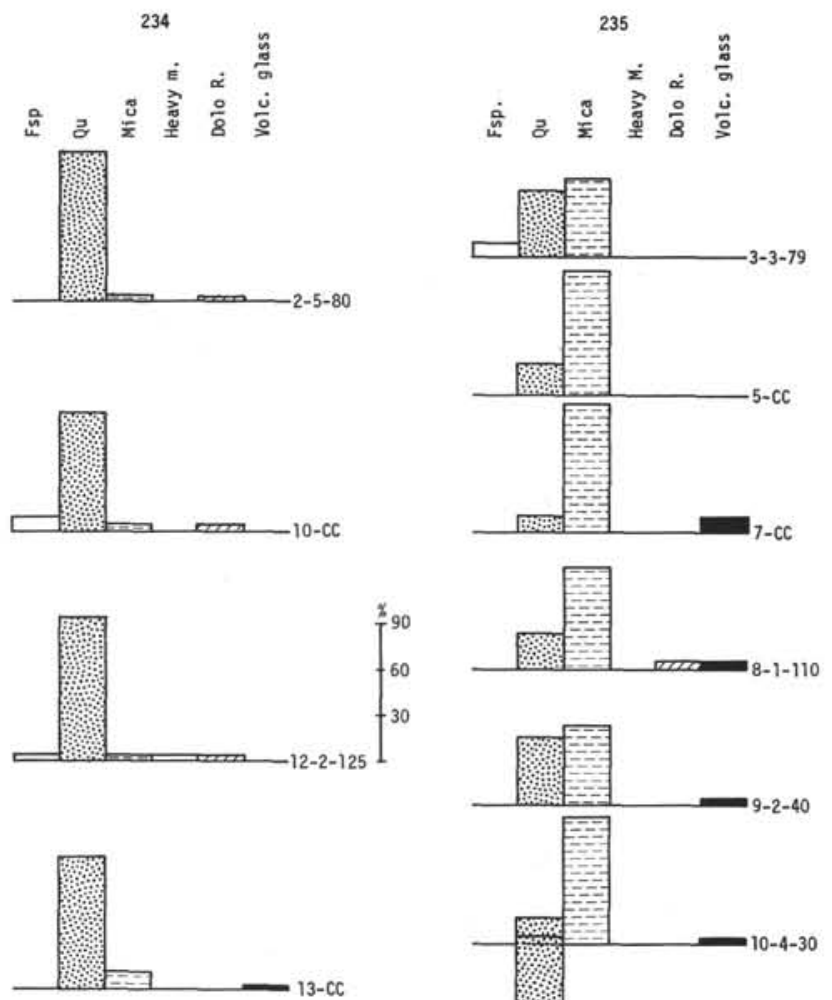
Percent of main terrigenous
components of coarse fractions

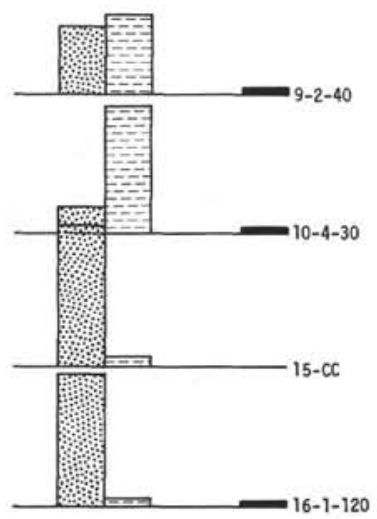

Figure 30. Characteristic terrigenous component assemblages of Site 234 and 235 sediments. Remark systematic differences of quartz and mica proportions.
The almost entirely calcareous sequence ranging from Paleocene to Recent was penetrated to a depth of 693.5 meters. Basement was not reached, but some of the recorded reflectors could be ascribed to chalk and chert layers in the nanno oozes. Cherts intercalated into nanno chalks were found mainly in Paleocene and lower Eocene sediments. The remaining sediments consist almost entirely of nanno to foram-rich nanno oozes (see Plate 7).

All samples investigated were texturally sands or sandy silts in post-lower Oligocene sediments, but sediments below were much more fine grained containing a higher proportion of coarse fraction only at the Paleocene base and in distinct horizons (Figure 4). Sedimentary structures, (Plate 7) usually consisting of layering indicated by slight color changes (in post-lower Eocene and in Paleocene sediments) or by textural changes (mainly basal sediments of site and lower Eocene deposits) are unevenly distributed throughout the section, as shown in Figure 36. Burrows were found only very occasionally and are either not present or not visible or preserved in the rather homogeneous sediments.

\section{Terrigenous Components}

Terrigenous components in the coarse fraction are rare (Figure 37b) and, except for volcanic glass, almost restricted to Paleocene sediments (Table 11), where heavily recrystallized calcareous rock fragments of unknown origin and, occasionally, quartz and dolomite rhombs are found. Brown and colorless volcanic glass was found in lower and middle Eocene sediments.

\section{Authigenic Components}

Glauconite (mostly as a filling of foraminiferal chambers) and chert fragments were the only authigenic components found in the coarse fractions of this site (Table 






B

(A) 24-235-13-1

Figure 31. Structures and burrows in
(76-99); (B) 24-235-15-3(128-150).

11). Both are rare (Figure 37b) and are restricted to lower Eocene and Paleocene sediments.

\section{Biogenic Components}

The biogenic components of these coarse fractions are dominantly calcareous throughout the section with the exception of a part of the Eocene deposits which contain almost only siliceous coarse-fraction components (Figure 37c).

Calcareous fossils consist of forams (benthic and planktonic), occasional pteropods, echinoid spicules, and rare ostracods.
Algal crusts and shallow-water larger benthic foraminifera were found in a number of horizons in the Paleocene sediments (Figure 38). These shallow-water biogenic components indicate that at least part of the sediment came from a shallow region. The sedimentary structures (frequent bedding and lensing in parts of the older sediments, see Plate 7) and the occurrence of glauconite in these sediments might be connected to this downslope transport of sediment.

Siliceous fossils consist of rare diatoms (only in one sample), Radiolaria, and sponge spicules. The latter two occur frequently in upper Miocene to upper Pliocene and dominantly in upper Eocene to upper Oligocene cores. 


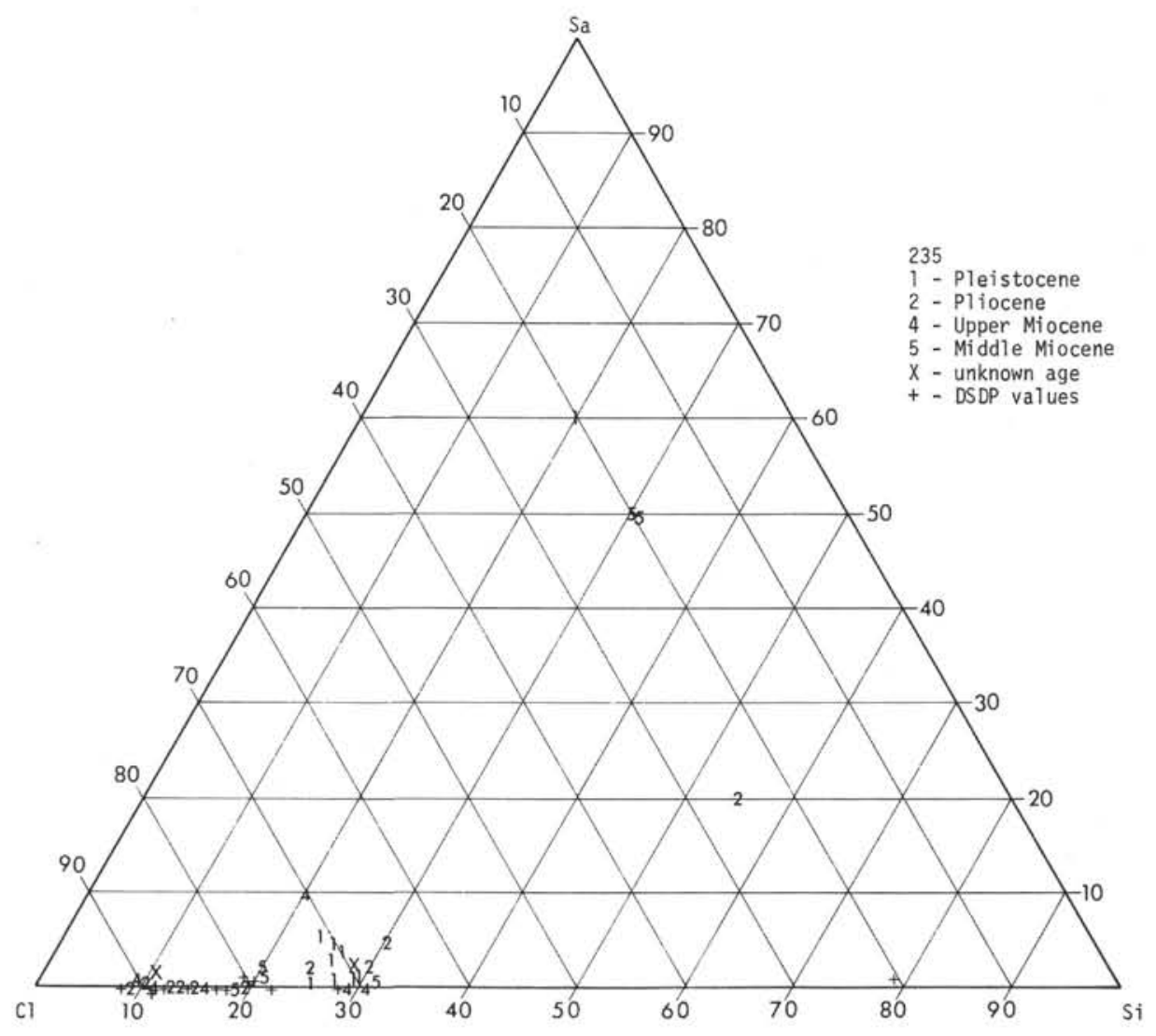

Figure 32a. Clay-silt-sand triangle diagram of Site 235, based on smear slide analyses.

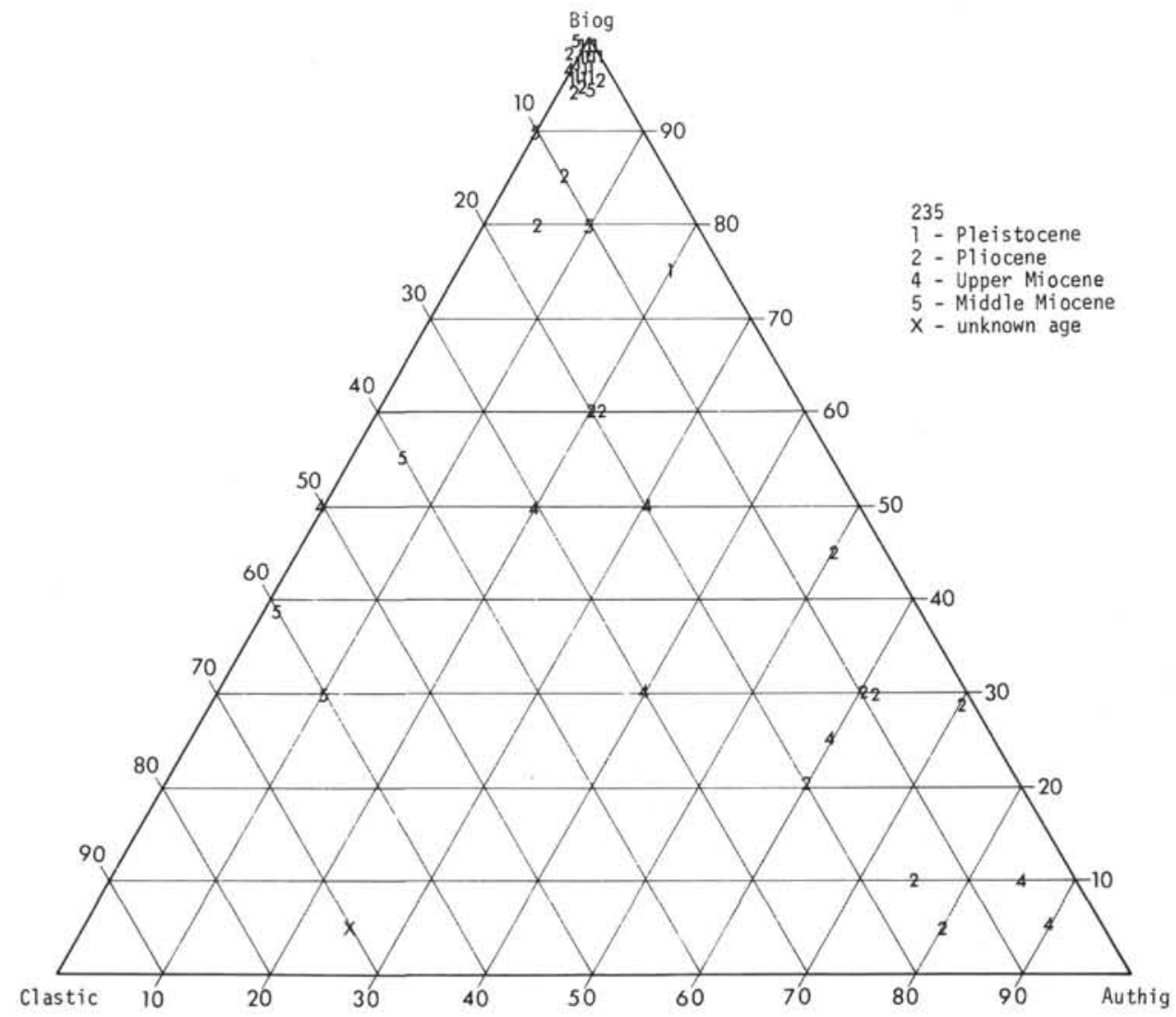

Figure 32b. Distribution of biogenic-clastic-authigenic components of Site 235 sediments, based on coarse grain analyses. 


\section{J. THIEDE}

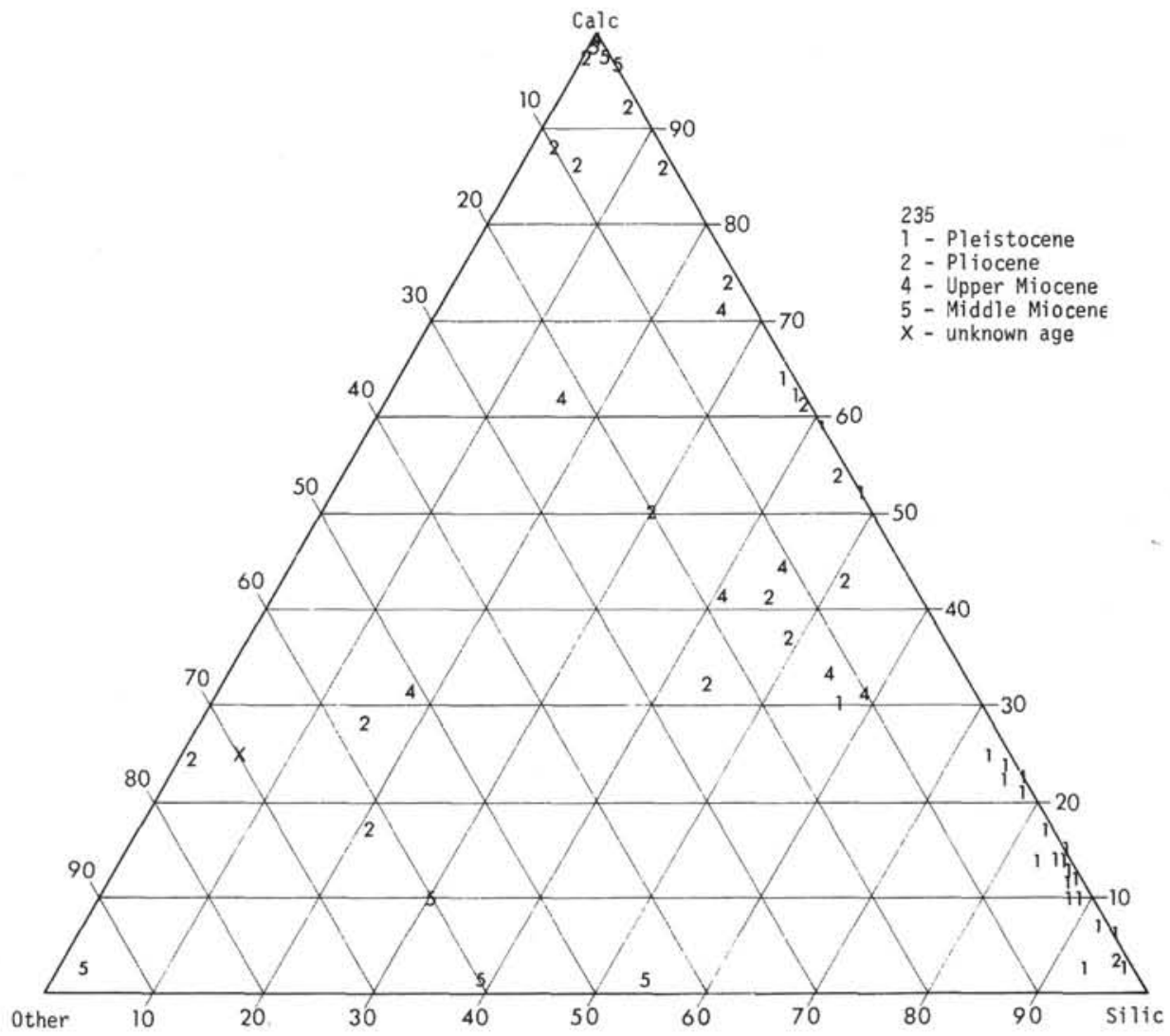

Figure 32c. Composition of tests and skeletons of Site 235 sediments (calcareous, siliceous and other material), based on coarse grain analyses.



Figure 33a. Clay-silt-sand triangle diagram of Site 236, based on smear slide analyses. 


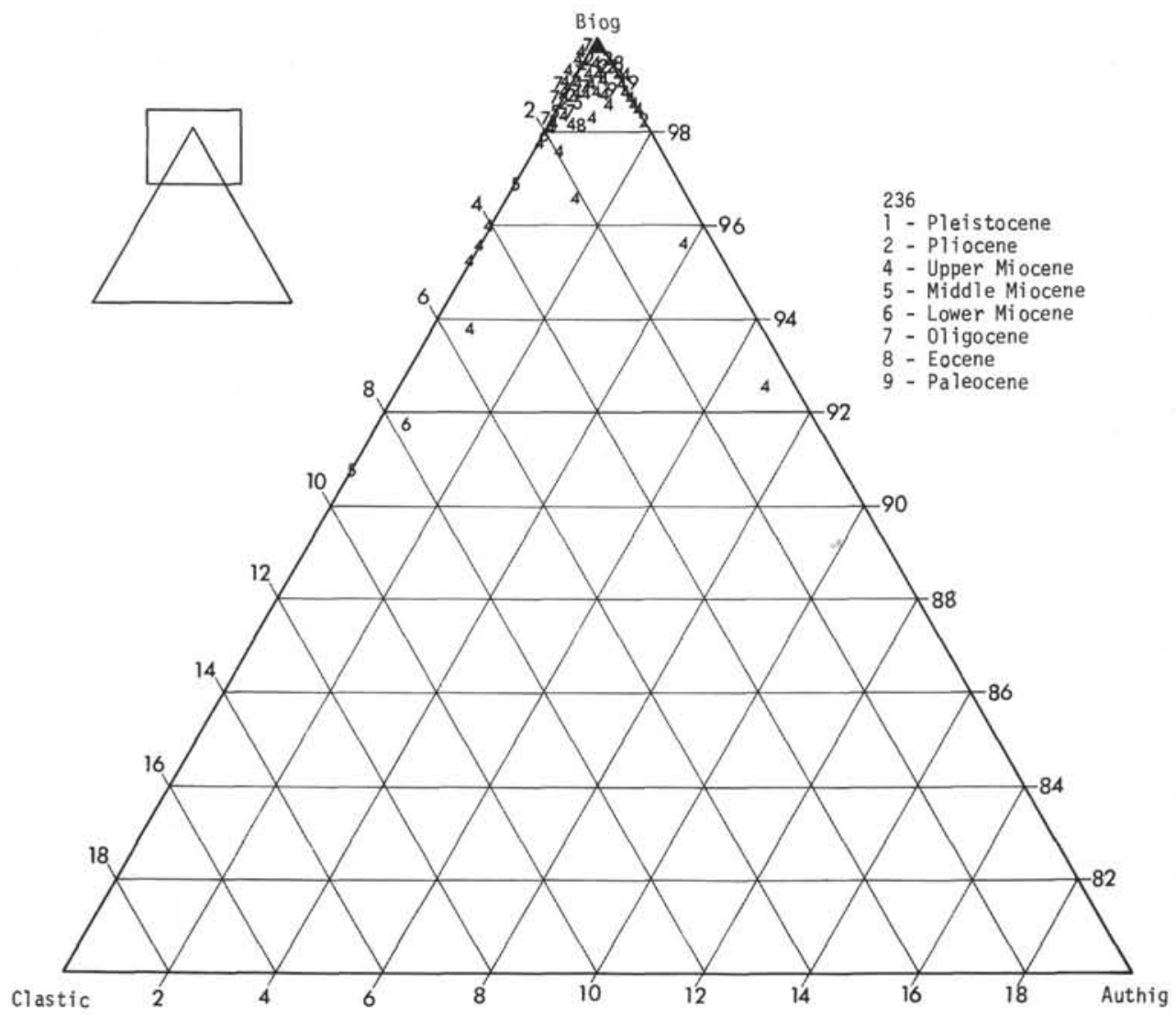

Figure 33b. Distribution of biogenic clastic-authigenic components in Site 236 sediments, based on coarse grain analyses. Only samples with $<100 \%$ biogenic components have been drawn up. Samples outsite field see small diagram.

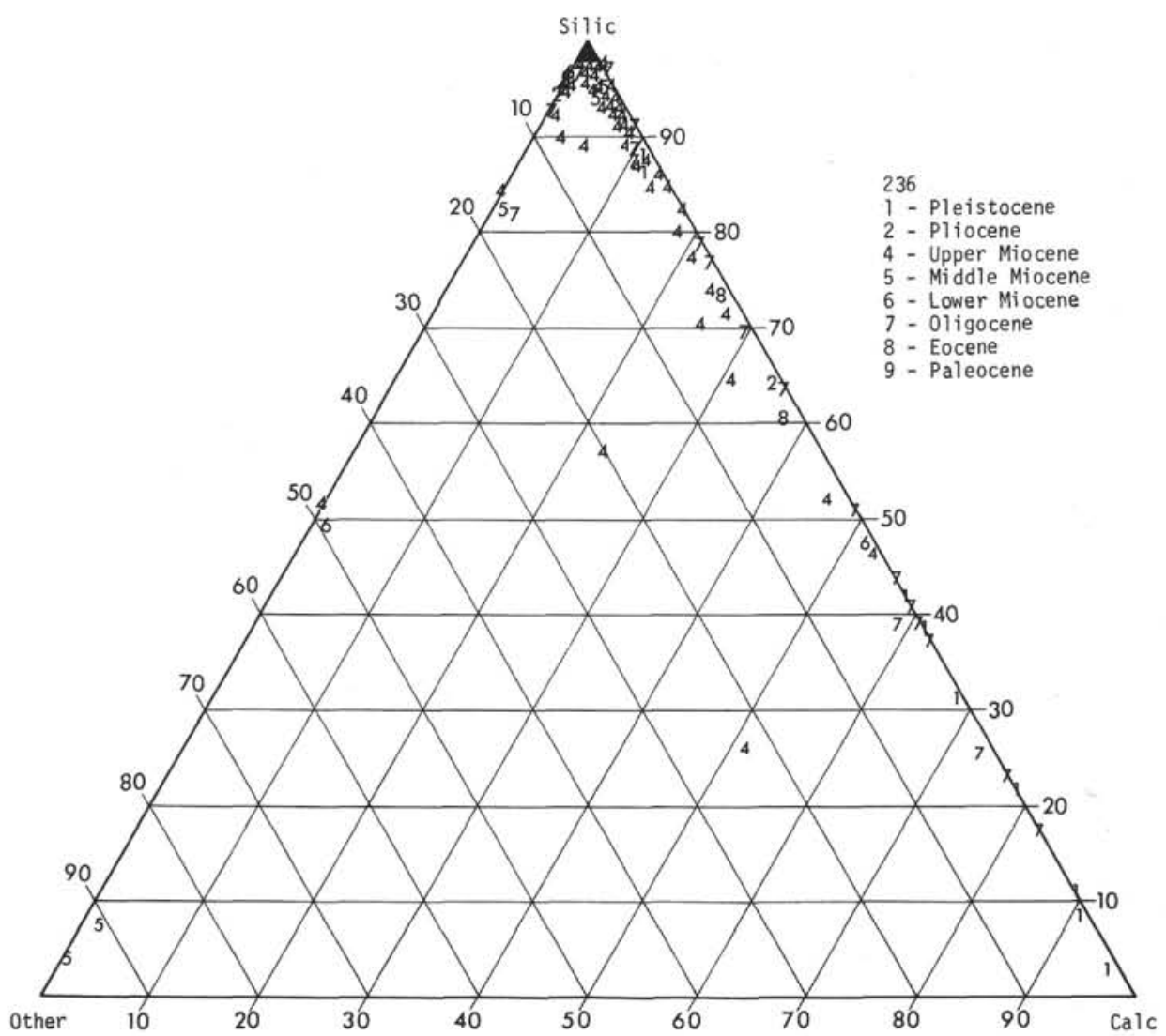

Figure 33c. Composition of tests and skeletons of Site 236 sediments (calcareous, siliceous and other material), based on coarse grain analyses. Only samples with $<98 \%$ calcareous fossils have been drawn up. 
TABLE 7

Terrigenous and Authigenic Coarse Fraction Components at Site 235

\begin{tabular}{|c|c|c|c|}
\hline Stratigraphy & Terrigenous Components & Authigenic Components & $\begin{array}{l}\text { Quartz/Mica Ratio } \\
\text { (min/max value) }\end{array}$ \\
\hline Pleistocene & $\frac{\text { Mica, quartz, volcanic }}{\text { glass }}$ & Pyrite, quartz & $0.3-1.0$ \\
\hline $\begin{array}{l}\text { Upper } \\
\text { Pliocene }\end{array}$ & $\begin{array}{l}\text { Quartz, volcanic glass, } \\
\text { Mica, quartz }\end{array}$ & Pyrite, quartz & $0.1-1.3$ \\
\hline $\begin{array}{l}\text { Lower } \\
\text { Pliocene }\end{array}$ & $\begin{array}{l}\text { Mica, quartz, volcanic } \\
\text { glass, dolo rhombs, } \\
\text { heavy minerals }\end{array}$ & Pyrite, quartz & $0.3-2.2$ \\
\hline $\begin{array}{l}\text { Upper } \\
\text { Miocene }\end{array}$ & $\frac{\text { Mica, quartz, volcanic }}{\text { glass }}$ & $\begin{array}{l}\text { Pyrite, quartz } \\
\text { (pyrite is many times } \\
\text { pseudomorphus after } \\
\text { siliceous biogenic } \\
\text { components }\end{array}$ & $0.2-14$ \\
\hline $\begin{array}{l}\text { Middle } \\
\text { Miocene }\end{array}$ & $\begin{array}{l}\text { Quartz, mica, heavy } \\
\text { minerals }\end{array}$ & $\begin{array}{l}\text { Pyrite, (also one } \\
\text { pyrite nodule about } \\
2 \mathrm{~cm} \text { ) }\end{array}$ & $2-14$ \\
\hline $\begin{array}{l}\text { Undated } \\
\text { Core } 16\end{array}$ & $\begin{array}{l}\text { Quartz, mica, volcanic } \\
\text { glass }\end{array}$ & $\begin{array}{l}\text { Zeolite, pyrite, } \\
\text { glauconite, quartz }\end{array}$ & 23 \\
\hline
\end{tabular}

aCommon to abundant components are underlined. All others occur only rarely.

Hystrichosphaerids and arenaceous benthic foraminifera are very scarce. Fish remains are rare to common.

\section{Coarse Fractions, Site 238}

Site 238 is situated in about 2800 meters of water close to the northwestern end of Argo Fracture Zone, near the junction of the Chagos-Laccadive Ridge and the Central Indian Ridge, an area extensively mapped and investigated by R. L. Fisher and his associates (Fisher, 1964; Fisher et al., 1971). Although missing the objective to sample the basement of the southern end of Chagos-Laccadive Ridge, oceanic basaltic basement was reached after penetrating a sedimentary section over 500 meters thick, ranging from lower Oligocene to Pleistocene in age. The sediments consist almost entirely of very light, purely pelagic, calcareous nannofossil oozes and chalks. They have been divided into three different sedimentary units based on slight changes in the proportions of the major components (almost entirely biogenic). A fourth unit consists of the basaltic cores with their sediment inclusions (Plate 9). The dominant color of the sediment is white, becoming pale orange to brownish due to a higher content of $\mathrm{Fe}$-oxides in the lower part of the section. The basal sediments of the section (belonging to unit 3) are more vividly colored due to their greater petrographic variations (volcanic ashes, zeolite sands, concentration of $\mathrm{Fe}$-oxides, see Figure 39). The sediments are so homogeneous that sedimentary structures are distinguished by slight color changes. However, thin sections of unconsolidated sediments of this site (Plate 8, Figures 1-3) show indications of current activity sorting the fine matrix of the sediments from the foraminiferal shells. Burrows have been detected only in Core 9 .

From 0 to 250 meters, the bulk of the sediments belongs texturally to silty clays and silty sands. Below they are mostly clayey silts (see Figure 32a and Figure 4). As at Site 237 , the sediments are generally fine grained in the older parts of the sections, although at Site 238 a slow but continuous decrease in grain size with increasing depth below sediment surface was found (Figure 4).
The calcium carbonate content is, in most of the investigated samples, very high (more than $85 \%$ ). Organic carbon content usually ranges from $0.0 \%$ to $0.1 \%$ with one occurrence of $0.4 \%$ at Sample $39-5,98 \mathrm{~cm}$. The X-ray diffraction analyses show, aside from calcite: dolomite, quartz, K-feldspar, plagioclase, mica, kaolinite, chlorite, montmorillonite, clinoptilolite, phillipsite, gypsum, and halite.

The coarse fractions consist almost entirely of biogenic components (Figure 40b). Only a very few Oligocene samples directly above basement contained a higher proportion of clastic and authigenic minerals (see Table 12).

\section{Terrigenous Components}

With the exception of the upper Oligocene and the lowermost lower Miocene sediments, terrigenous grains were too rare in the coarse fractions to be meaningful. They consist commonly of isolated grains of quartz/and volcanic glass fragments. Only in the lowermost part of this sedimentary section do terrigenous components make up a larger proportion of the sediments: light and dark volcanic glass, quartz, heavy minerals, and calcareous rock fragments of unknown origin. A volcanic ash layer occurs at Sample $24-238-53-2,53 \mathrm{~cm}$. With the exception of the calcareous rock fragments, all these minerals are assumed to be related to volcanic activity whose influence and input into the sediments decrease as this site (and its sediments) were removed from the active rift zone. The calcareous rock fragments are very fine grained and recrystallized and might be indurated calcareous ooze. However, they are surprisingly angular. Their coincidence with the volcanic material may, therefore, not be accidental. They may come from the same source and were affected by the volcanism.

\section{Authigenic Components}

The distribution of authigenic components shows a close correlation to terrigenous material. Pyrite is scarce in the upper part of the section. In the lower part micronodules of Fe-oxides, pyrite, and zeolite occur in the metalliferous basal sediments. 

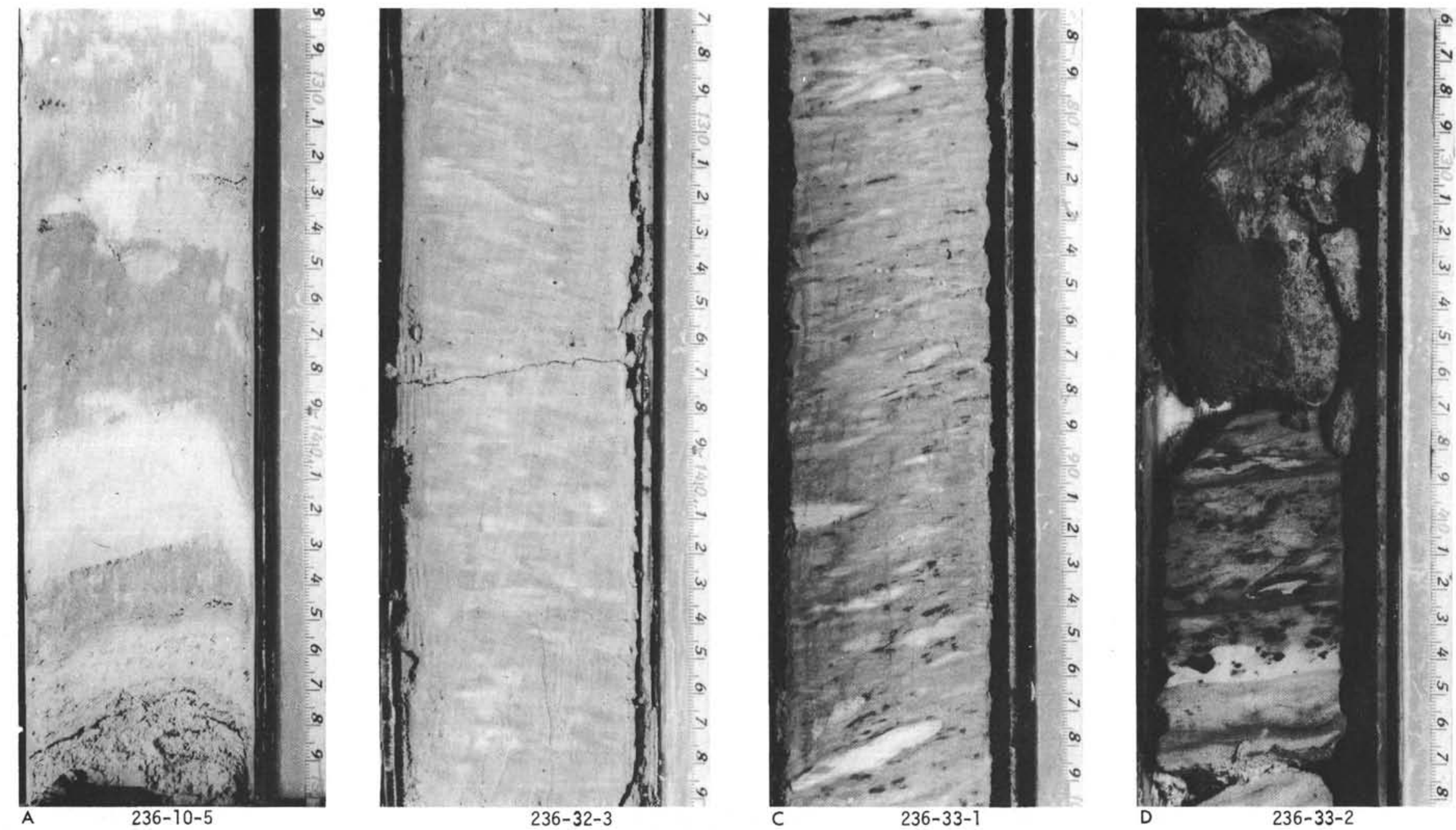

Figure 34. Sedimentary structures in Site 236 sediments: (A) 24-236-10-5 (128-150), upper Miocene nanno ooze; (B) 24-236-32-3 (128-150), upper Paleocene/ lower Eocene nanno chalk;(C and D) 24-236-33-1 (77-100) and 24-236-33-2 (25-49), upper Paleocene nanno chalk. 


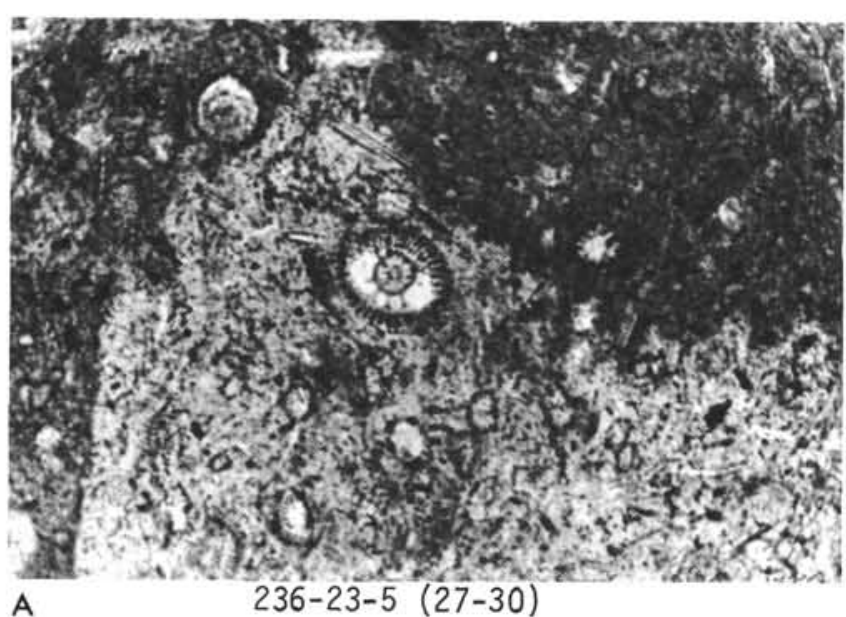

A

$236-23-5(27-30)$

$.05 \mathrm{~mm}$



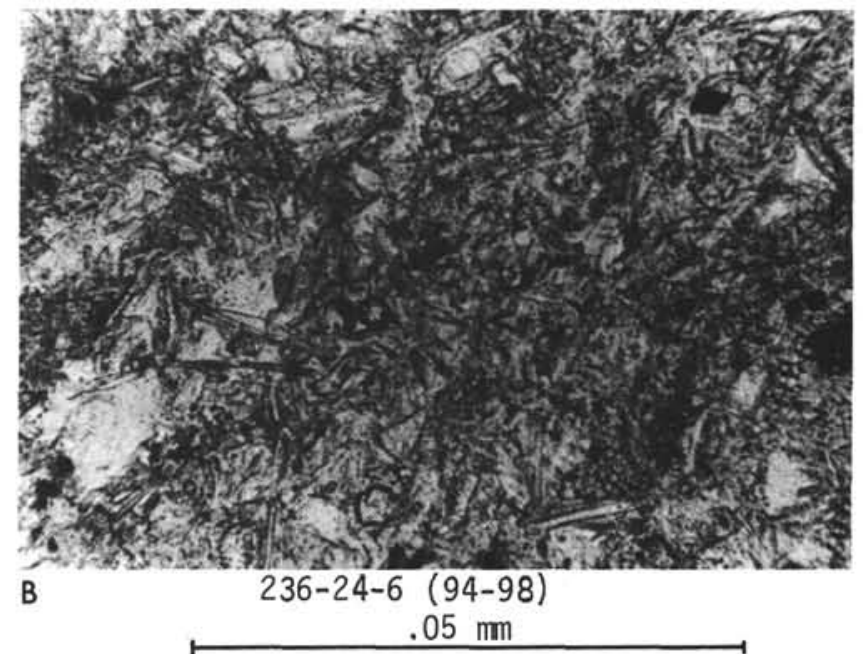

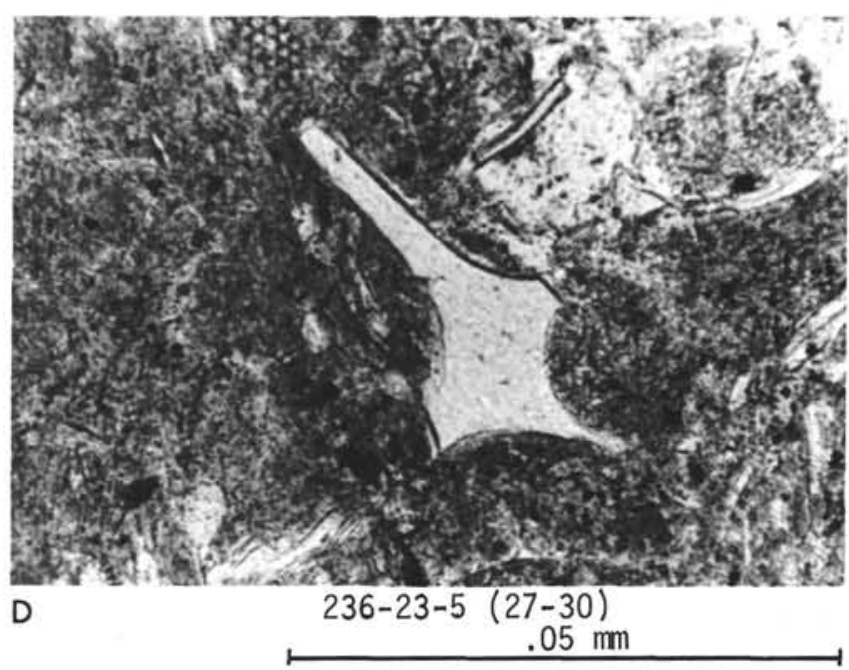

Figure 35. Oligocene nanno oozes and chalk (very rich in well preserved siliceous components; especially radiolaria, sponge spicules and volcanic glass shards) of Site 236 (thin sections). (A) 24-236-23-5(27-30); (B and C) 24-236-24-6(94-98); and (D) 24-236-23-5(27-30).

\section{Biogenic Components}

The biogenic component of this coarse fraction consists almost entirely of calcareous shells and planktonic foraminifera. Only a few Pleistocene and upper Miocene samples contain a considerable amount of siliceous tests and skeletons (Figure 40c). Although the dominance of the calcareous tests is so overwhelming, there is nearly almost always a small contribution of siliceous material.

Calcareous biogenic components consist predominantly of benthic and planktonic foraminifera, but they also include rare pteropod fragments (lower Miocene and upper Oligocene), rare ostracods, and rare echinoid spicules. Planktonic foraminifera contribute the dominant portion of these coarse fractions except a few horizons, mainly in Pleistocene cores, where siliceous components prevail.

Siliceous biogenic components consist of diatoms, Radiolaria, and sponge spicules. Diatoms are very rare in sediments older than upper Miocene, but they become increasingly more abundant in younger sediments and are the dominant component in a number of Pleistocene samples (Figure 16). Radiolaria were found frequently in middle Miocene to Pleistocene sediments, but are almost absent in the older deposits (lower Miocene to upper Oligocene). Sponge spicules are a common to frequent component in almost all samples. Only in middle Miocene sediments do they seem to be somewhat enriched.

Fish debris, arenaceous foraminifera, and hystrichosphaerids occur rarely.

\section{REGIONAL DISTRIBUTION OF COMPONENTS}

A regional distribution of single coarse-fraction components is shown in Figures 12-18 and 4146. 
237

Depth below

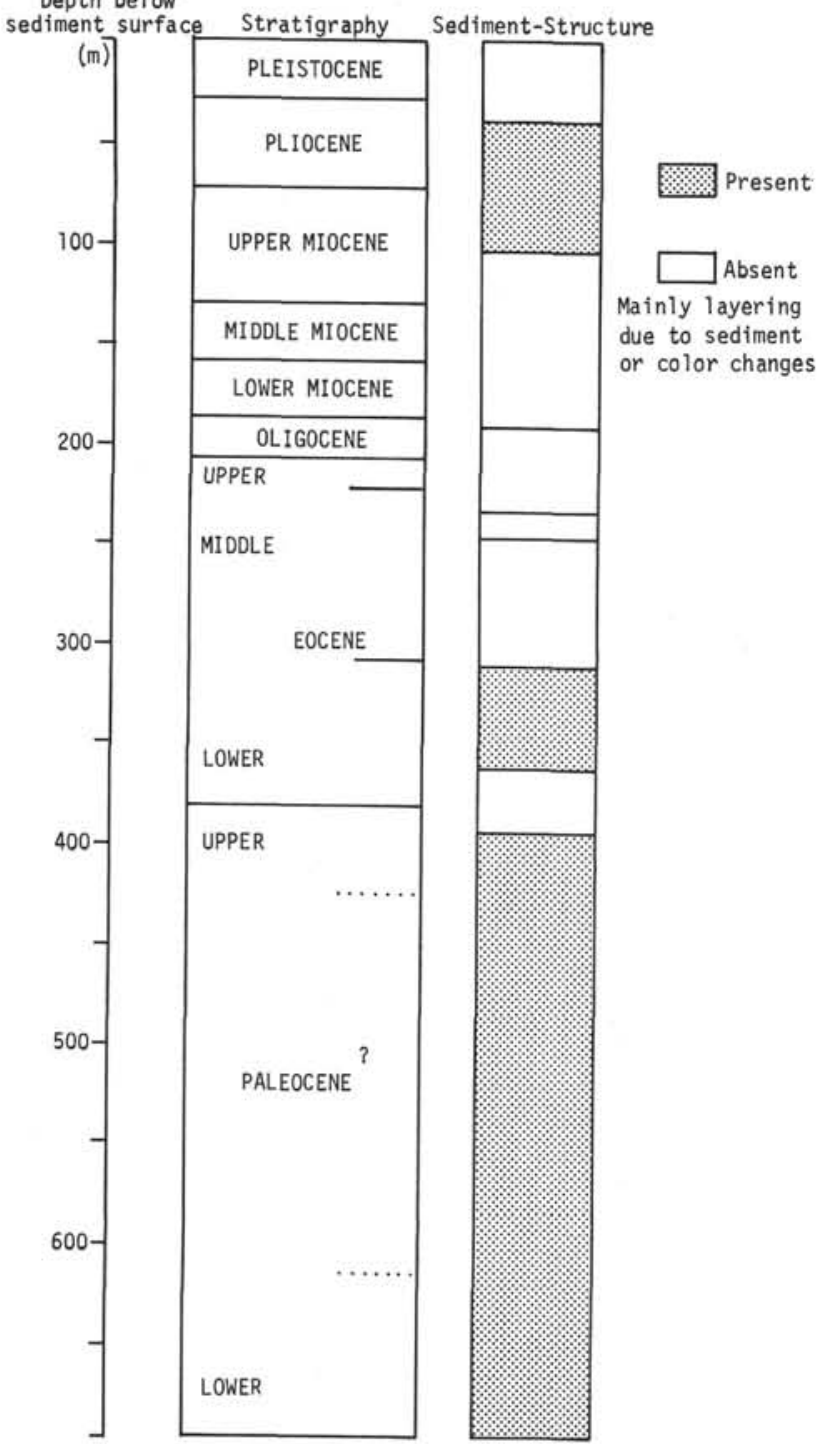

Figure 36. Distribution of primary sedimentary structures in Site 237 sediments.

\section{Terrigenous Components}

Coarse fraction analysis is probably not a definitive method for studying terrigenous material in an area where the bulk of these components presumably is eolian in origin; in such a region terrigenous material is not contained in the sand fraction, but rather in the silt and clay fraction (Füchtbauer and Müller, 1970). A definite trend, high clastic terrigenous input to the Gulf of Aden, decreasing in the Somali Basin and almost disappearing in the central Indian Ocean sites, was found. Not only does the proportion of clastic terrigenous components decrease, but so does the grain size. The compositions of the mineral assemblages also change in a characteristic way. Quartz/mica ratios decrease with increasing distance from land.

The wind-transported material in the Gulf of Aden came presumably from the surrounding desert areas. Because of the generally similar land geology on both sides of the Gulf of Aden (Beydoun, 1970), it seems difficult to indicate the
TABLE 8

Terrigenous and Authigenic Components at Site 236

\begin{tabular}{|c|c|c|}
\hline Stratigraphy & Terrigenous Components & $\begin{array}{c}\text { Authigenic } \\
\text { Components }\end{array}$ \\
\hline \multicolumn{3}{|l|}{ Pleistocene } \\
\hline Pliocene & $\begin{array}{l}\text { Quartz, dolo rhombs, } \\
\text { rock fragments }\end{array}$ & Glauconite \\
\hline $\begin{array}{l}\text { Upper } \\
\text { Miocene }\end{array}$ & $\begin{array}{l}\text { Quartz, mica, }{ }^{a} \text { rock } \\
\text { fragments, dolo rhombs } \\
\text { volcanic glass }\end{array}$ & $\begin{array}{l}\text { Glauconite, pyrite, } \\
\text { zeolite }\end{array}$ \\
\hline $\begin{array}{l}\text { Middle } \\
\text { Miocene }\end{array}$ & $\begin{array}{l}\text { Quartz, mica, }{ }^{\mathrm{a}} \text { heavy } \\
\text { minerals, dolo rhombs, } \\
\text { volcanic glass }\end{array}$ & \\
\hline $\begin{array}{l}\text { Lower } \\
\text { Miocene }\end{array}$ & $\begin{array}{l}\text { Quartz, dolo rhombs, } \\
\text { volcanic glass }\end{array}$ & Pyrite, zeolite \\
\hline Oligocene & $\begin{array}{l}\text { Quartz, mica, }{ }^{\mathrm{a}} \text { dolo } \\
\text { rhombs, volcanic glass }\end{array}$ & \\
\hline Eocene & Quartz & Zeolite, quartz(?) \\
\hline $\begin{array}{l}\text { Upper } \\
\text { Paleocene }\end{array}$ & Quartz & Glauconite, pyrite \\
\hline
\end{tabular}

aToo few grains to determine quartz/mica ratio.

TABLE 9

Dccurrence of Rock Fragments and Volcanic Ashes in Sediments at Site 236

\begin{tabular}{|c|c|}
\hline \multicolumn{2}{|c|}{ Rock Fragments } \\
\hline $\left.\begin{array}{l}3-2,55 \\
3-2,78\end{array}\right\}$ & Pliocene \\
\hline $\left.\begin{array}{l}5-1,93 \\
5-3,89 \\
5-4,62 \\
6-4,68 \\
7-5,98 \\
8-4,43 \\
9-4,84\end{array}\right\}$ & Upper Miocene \\
\hline \multicolumn{2}{|c|}{ Volcanic Ashes } \\
\hline $18, \mathrm{CC}$ & Lower Miocene \\
\hline $\left.\begin{array}{l}22-1,130 \\
23-6,76 \\
23, C C\end{array}\right\}$ & Oligocene \\
\hline
\end{tabular}

TABLE 10

Shallow-Water-Derived Fossils at Site 236

\begin{tabular}{cll}
\hline $3-2,66 \mathrm{~cm}$ & Coral & Upper Pliocene \\
$5-1,93 \mathrm{~cm}$ & Bryozoan & \\
$5-3,89 \mathrm{~cm}$ & Algae, bryozoan \\
$5-6,80 \mathrm{~cm}$ & Bryozoan & Upper Miocene \\
$6-3,134 \mathrm{~cm}$ & Bryozoan & \\
$12-6,46 \mathrm{~cm}$ & Bivalve (?) & \\
\hline
\end{tabular}

source area more precisely in this preliminary study. The rock fragments and rounded quartz grains found in several horizons in the sediments at Sites 231 and 232 together with shallow-water fossils must have been water transported and can come only from either side of the gulf.

The terrigenous components in the Somali Basin are distinct on either side of Chain Ridge, suggesting different sources for these sediments. The composition of the terrigenous coarse-fraction components at Site 234 is so similar to the Gulf of Aden distribution that it seems 


\section{J. THIEDE}
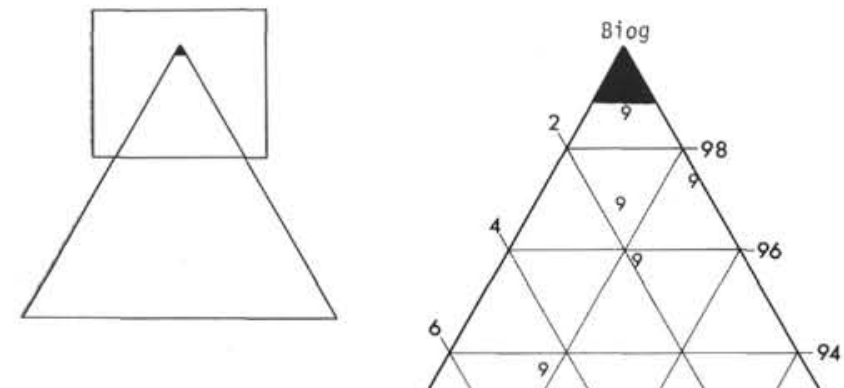

1 Pleístocene

2 Pliocene

4 Miocene

7 oligocene

8 Eocene - barren

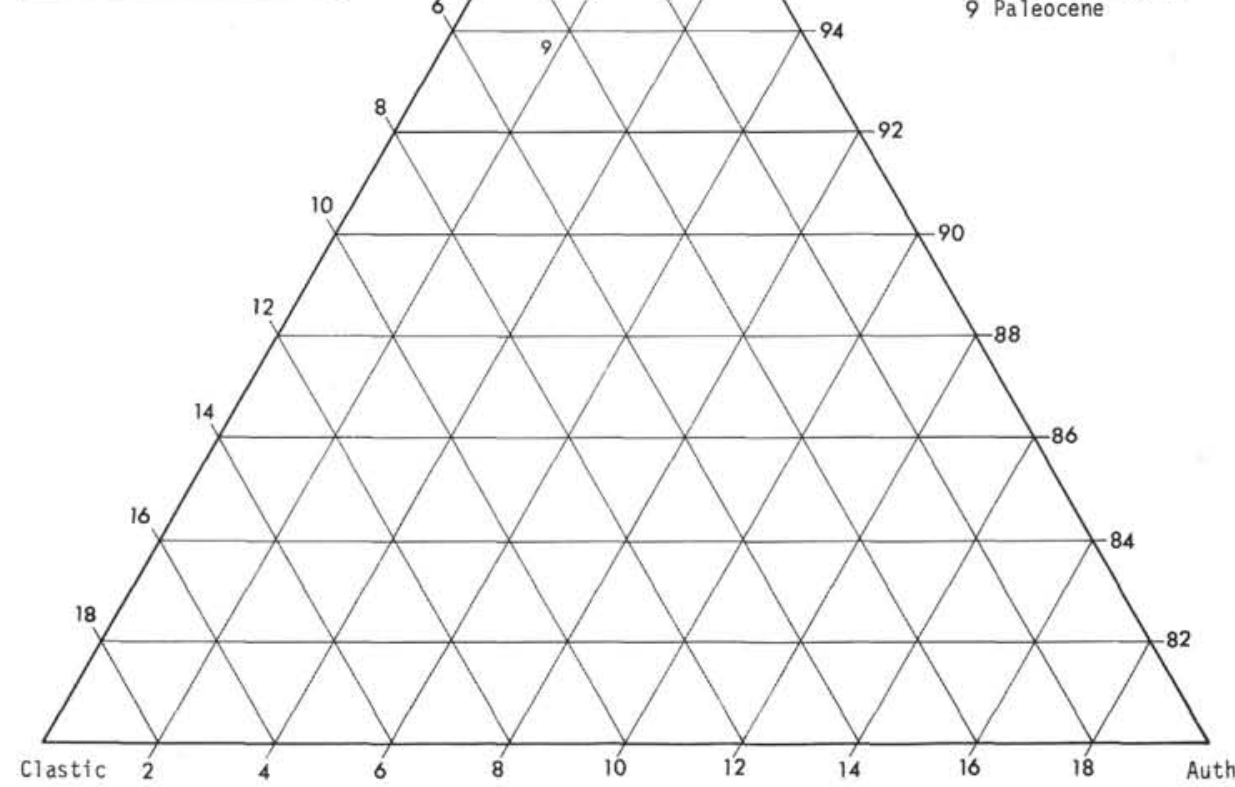

Figure 37a. Clay-silt-sand triangle diagram of Site 237, based on smear slide analyses.

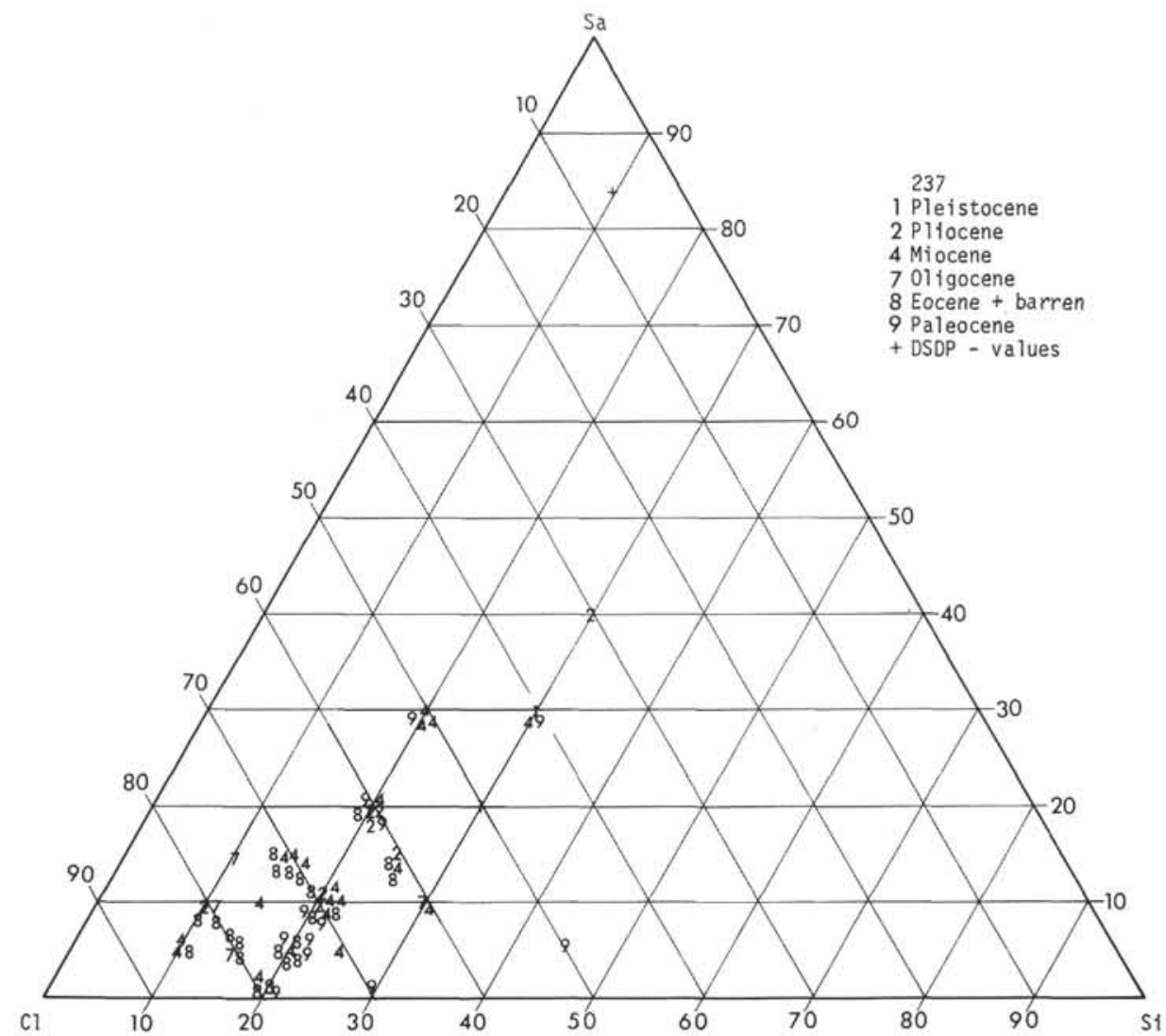

Figure 37b. Distribution of biogenic-clastic-authigenic components of Site 237 sediments, based on coarse grain analyses. Only samples with $<99 \%$ biogenic components have been drawn up. 

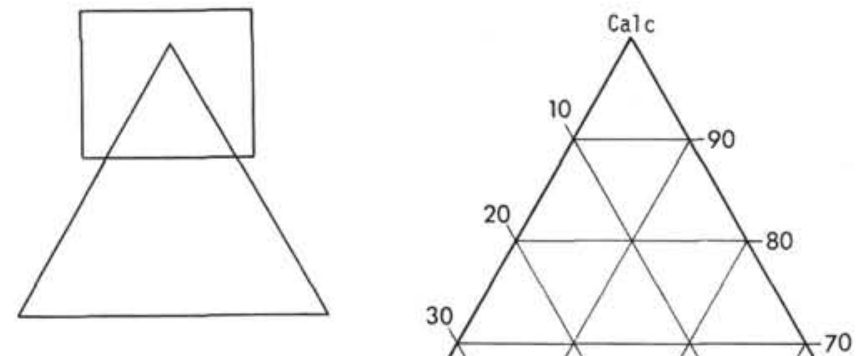

237

1 Pleistocene

2 Pliocene

4 Miocene

7 0ligocene

8 Eocene + barren

9 Paleocene


Figure $37 \mathrm{c}$. Composition of tests and skeletons of Site 237 sediments (calcareous, siliceous and other material), based on coarse grain analyses. Only samples with $<99 \%$ calcareous fossils have been drawn up. 
TABLE 11

Terrigenous and Authigenic Components at Site 237

\begin{tabular}{|c|c|c|}
\hline Stratigraphy & Terrigenous Components & $\begin{array}{l}\text { Authigenic } \\
\text { Components }\end{array}$ \\
\hline \multicolumn{3}{|l|}{$\begin{array}{l}\text { Oligocene to } \\
\text { Pleistocene }\end{array}$} \\
\hline $\begin{array}{l}\text { Middle } \\
\text { Eocene }\end{array}$ & $\begin{array}{l}\text { Volcanic glass (brown } \\
\text { and light) }\end{array}$ & \\
\hline $\begin{array}{l}\text { Lower } \\
\text { Eocene }\end{array}$ & Volcanic glass & $\begin{array}{l}\text { Glauconite, chert } \\
\text { fragments }\end{array}$ \\
\hline Paleocene & $\begin{array}{l}\text { Quartz, dolo rhombs, } \\
\text { rock fragments (heavy } \\
\text { heavily recrystallized } \\
\text { calcareous rocks, in } \\
\text { Sample } 3-90,47-120 \mathrm{~cm} \text { ) }\end{array}$ & $\begin{array}{l}\text { Glauconite (mostly } \\
\text { fillings of foram } \\
\text { chambers), chert } \\
\text { fragments }\end{array}$ \\
\hline
\end{tabular}



Figure 38. 24-237-41-2,140 polished section. Horizon of silicified shallow water benthic foraminifera (-Discocyclina) in upper Paleocene chalks. Upper and lower boundary of this horizon are both sharp. Compare for details, Chapter 19, this volume.

TABLE 12

Terrigenous and Authigenic Components at Site 238

\begin{tabular}{lll}
\hline Stratigraphy & Terrigenous Components & \multicolumn{1}{c}{$\begin{array}{c}\text { Authigenic } \\
\text { Components }\end{array}$} \\
\hline $\begin{array}{l}\text { Pleistocene } \\
\text { Pliocene }\end{array}$ & Pyrite \\
$\begin{array}{l}\text { Upper } \\
\text { Miocene }\end{array}$ & Volcanic glass & Pyrite \\
$\begin{array}{l}\text { Middle } \\
\text { Miocene }\end{array}$ & \\
$\begin{array}{l}\text { Lower } \\
\text { Miocene }\end{array}$ & $\begin{array}{l}\text { Volcanic glass, quartz, } \\
\text { rock fragments } \\
\text { (calcareous, heavily } \\
\text { recrystallized) }\end{array}$ & Pyrite \\
$\begin{array}{l}\text { Volcanic glass (light } \\
\text { Oligocene }\end{array}$ & $\begin{array}{l}\text { and dark), dolo rhombs, } \\
\text { calcareous rock fragments, } \\
\text { quartz, heavy minerals. }\end{array}$ & \\
& $\begin{array}{l}\text { Volcanic ash at Sample } \\
53-2,53 \mathrm{~cm}\end{array}$ & \\
&
\end{tabular}

difficult not to accept an African/Arabian source area. Goldberg and Griffin (1970) described very similar silt-sized mineral assemblages caught in the southwest monsoon. The monsoon is capable of carrying a heavier dust load than the other winds of the area.

The almost complete absence of clastic terrigenous coarse-fraction components in the central Indian Ocean does not allow any obvious regional conclusion to be drawn. However, granitic rock fragments at Site 236, north of the Seychelles, must have their origin in the weathering continental basement of this area.

Volcanic ashes composed of almost colorless glass are found in a number of sites. Their common occurrence in pelagic sediments might be correlated to differentiation of dissolved gas phases from extruding lavas during volcanic activity along the rift.

\section{Authigenic Components}

Distributions of authigenic components are discussed for individual sites in the preceding section.

\section{Biogenic Components}

Tests and fragments of planktonic foraminifera are the more ubiquitous components of the coarse fractions in all eight drill sites from the northwestern Indian Ocean and the Gulf of Aden. Fragments and whole tests have been counted separately, but in Figure 12 only the distribution of the maximal occurrence of the whole tests in each core is given. They are common to abundant at all holes although the water depths of the eight sites range from over 5000 meters in the Somali Basin to less than 2000 meters both for a Mascarene Plateau site in the central Indian Ocean sites and the two Alula-Fartak sites in the Gulf of Aden. This suggests that, at least for the Somali Basin localities, there is a considerable amount of redeposited material. It is expected that those sites lying either beneath or very close to the calcium carbonate compensation depth should have fragmented planktonic foraminifera (Thiede, 1973a) which may eventually be dissolved (Berger and von Rad, 1972).

The shallow central Indian Ocean sites are much more homogeneous than the Gulf of Aden sites, suggesting that planktonic foraminifera are less common and less well preserved in the hemipelagic sediment than in the open ocean. The effect is well known from other areas of the world ocean (Berger, 1971), although the normal pattern of calcium carbonate preservation on continental margins (Thiede, 1973a) is expected to vary in this area due to the extremely well-developed oxygen minimum of the upper water masses in the northern Indian Ocean (Wyrtki, 1971; von Stackelberg, 1972).

The aragonitic shells of pteropods are much more susceptible to dissolution, therefore they were rarely found (Figure 13). As they usually are not preserved in water depth greater than about 2500 meters, they are good indicators for sediments which are displaced (for example, Sites 235 and 236). They occur commonly in the Pleistocene deposits at Site 231 combined with other displaced components from shallower water depths (Herman, 1971; Stubbings, 1939). Larvae of gastropods and bivalves rarely are found in the Gulf of Aden sediments. These delicate shells also occur only in displaced material from the continental margin. 


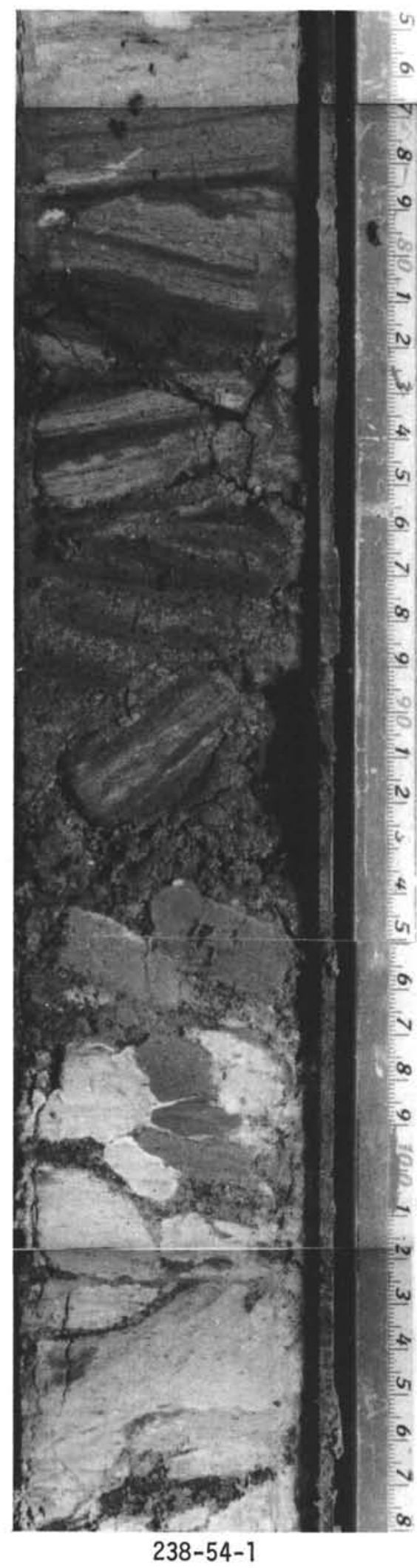

Figure 39. Basal lower Oligocene sediments of Site 238 (24-238-54-1, 75-110) consisting of grayish orange nanno fossil oozes with intercalated thin zeolitic sand layers and volcanic ashes consisting of colorless glass.
Ostracods occur rarely, but are widely distributed at all sites. Limited knowledge about their distribution pattern in oceanic sediments (Puri, 1971) precludes further discussion.

\section{Calcareous Benthos}

Aside from a number of shallow-water-derived components, which will be discussed later, calcareous foraminifera and echinoids are the dominant contributors of calcareous tests or fragments of benthic origin in deep-sea sediments. Foraminifera are the most abundant shellbearing benthic calcareous deep-sea organisms which are usually deposited at very constant sedimentation rates (Thiede, 1973b). However, regional quantitative differences between the highly fertile upwelling areas off Somalia and Arabia and the central water masses of the Indian Ocean are clearly expressed (Figure 14). The proportion of the biogenic coarse fraction which consists dominantly of benthic foraminifera is also higher in samples which have undergone considerable dissolution (Berger, 1970), for example, at Sites 234, 235, and 236. Because of the presence of displaced sediments from shallower water depths, it seems important to study the pattern of calcium carbonate deposition and preservation in greater detail.

After foraminifera, echinoids are the next most important benthic producer of calcareous particles in the deep sea (Figure 15). They occur, as other benthos does, more frequently in the more fertile areas of upwelling of Somalia and Arabia (Kudrass, 1973). In other respects echinoid spicules are as homogeneously distributed in the deep-sea sediments as benthic foraminifera, suggesting that this distribution is generally very characteristic for deep-sea benthos.

\section{Siliceous Fossils}

The siliceous biogenic assemblage of these coarse fractions consists of diatoms, Radiolarians, and sponge spicules (Figures 16, 17, and 18). The fragile skeletons of diatoms are not a usual component of deep-sea coarse fractions due to their susceptibility to dissolution either while still in the water column or, after deposition, in the sediments (Schrader, 1971a and b). Except in single horizons at Sites 232 and 233 and very isolated occurrences at 231, they were not found in the Gulf of Aden (Figure 16). They are almost absent in the sediments from the Somali Basin west of Chain Ridge (Site 234), but they constitute an important component in the Pleistocene sediments at Site 235 east of Chain Ridge, decreasing rapidly in abundance with increasing age during the Tertiary and missing from the lowermost part of the section. Diatoms are almost absent from Site 237, but occur in lower Oligocene and Pleistocene sediments at Site 236 and appear still more frequently in the deposits of 238 , decreasing in abundance downwards over the whole length of the cored section.

Radiolarian skeletons and siliceous sponge spicules (Figures 17 and 18) correlate almost perfectly with one another with respect to their abundance in the coarse fraction. They occur in the deposits of all sites, and in many samples they are the dominant biogenic component. Their abundance clearly changes vertically at Sites 231 , $234,235,236,237$, and 238 , but they occur in almost 




Figure 40a. Clay-silt-sand triangle diagram of Site 238, based on smear slide analyses.



Figure 40b. Distribution of biogenic-clastic-authigenic components in Site 238 sediments, based on coarse grain analyses. Only samples with $<99 \%$ biogenic components have been drawn up. 



Figure 40c. Composition of tests and skeletons of Site 238 sediments (calcareous, siliceous and other material); based on coarse grain analyses. Only samples with $<99.8 \%$ calcareous material have been drawn up. 
constant quantities in the sediments from Sites 232 and 233. The correlation between sites with relation to these benthic and planktonic components is not well understood. However, if all the siliceous components at one site are compared, the coincidence of the occurrence of these components is striking. Sites 236 and 238 have been chosen as examples (Figure 41). The occurrence of siliceous sponge spicules and radiolaria is almost parallel while diatoms always can be correlated to the maximum abundance of both other components. Radiolaria always exceed the range of the diatoms, sponge spicules always that of Radiolaria. This strongly suggests that the siliceous components in these coarse fractions are subject to selective solution. Diatoms are dissolved before Radiolaria and Radiolaria before sponge spicules. A similar sequence of $\mathrm{SiO}_{2}$ solution has been described, although on a smaller scale, by Schrader (1972a and b) from Quaternary sediments of the north Atlantic Ocean.

It is therefore rather questionable how much paleoclimatic evidence can be drawn from these components which should be indicators of the high production belt close to the tropical divergence (Casey, 1971; Kozlova, 1971; Lisitzin, 1971). The production of these skeletons decreases, at least in the Pacific, north and south of this belt which seems to have been rather stable throughout the Tertiary (Riedel, 1971). However, it seems clear that the sediments were situated close to or under this belt if the preserved siliceous fossils are as dominant since Miocene as at Site 238, and as at 236 in Oligocene, upper Miocene, and Plio/Pleistocene sediments.

One might express this dominance of siliceous fossils, in particular Radiolaria, by calculating a ratio

$$
\mathrm{R}=\frac{\text { planktonic foraminifera (whole tests and fragments) }}{\text { Radiolaria }}
$$

for all sites (Figure 42). The dominance of the siliceous fossils in the horizons cited seems to offer good evidence for a former position under this tropical belt, if the present location of the site has been removed from this climatic zone because of movement of the oceanic crust (Berger, 1973). Radiolaria, however, also occur rather frequently in the northern part of the Indian Ocean (Petrushevskaya, 1971).

\section{Fossils Consisting of Other Biogenic Material}

The following fossils consisting of other biogenic material and not derived from shallow coastal waters must be mentioned.

Arenaceous benthic foraminifera were found at all sites (Figure 43). Following the trend of other benthos, they occur more frequently in the hemipelagic sediments at Sites 231 and 232 (but not 233). Their abundant occurrence in sediments at Sites 231 and 232 is striking in comparison to their scarcity at all other sites, even those of similar water depth (close to islands) of the open ocean. Although arenaceous foraminifera are also known as ubiquitous, but scarce deep-sea organisms, higher abundances of them in deep-sea sediments from temperate, subtropical, and tropical climatic zones might be indicative of a hemipelagic sedimentary environment close to the continental margin. However, their geological importance is expected to be
236

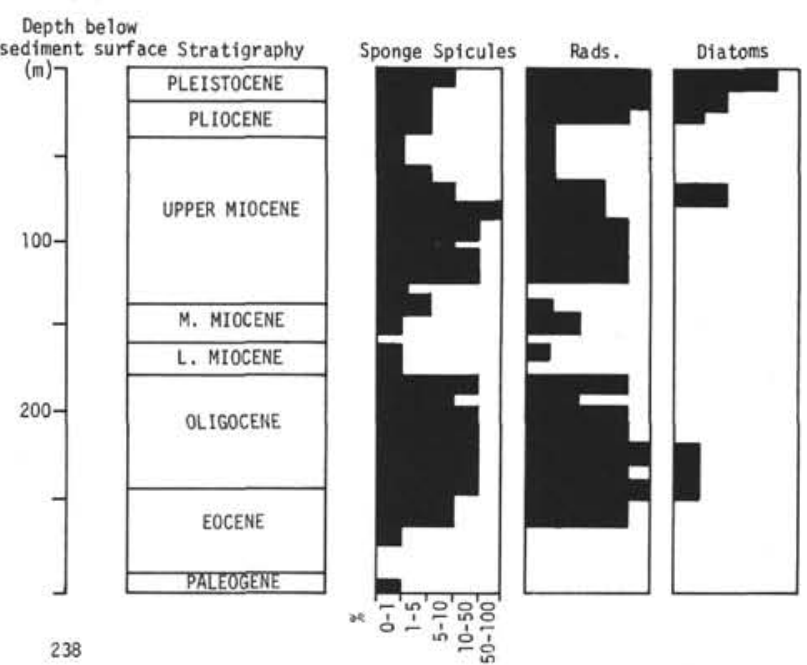

Depth below



Figure 41. Distribution of silicous components of coarse fraction of Sites 236 and 238. Values indicated are maximal percentages of the biogenic components per core.

rather restricted, since they are rarely preserved in marine deposits, but they usually are subject to rapid diagenetic destruction due to dissolution of the cementing substance of their shells (Kudrass, 1973).

The other important biogenic component of nonsiliceous and noncalcareous composition in oceanic coarse fractions are fish remains (Figure 44). If preserved, they are found as accessories in all types of sediment (Berger and von Rad, 1972). If the diluting components have been dissolved, the proportion of fish debris rises considerably. This is well documented in sediments from Sites 234, 235, 
231

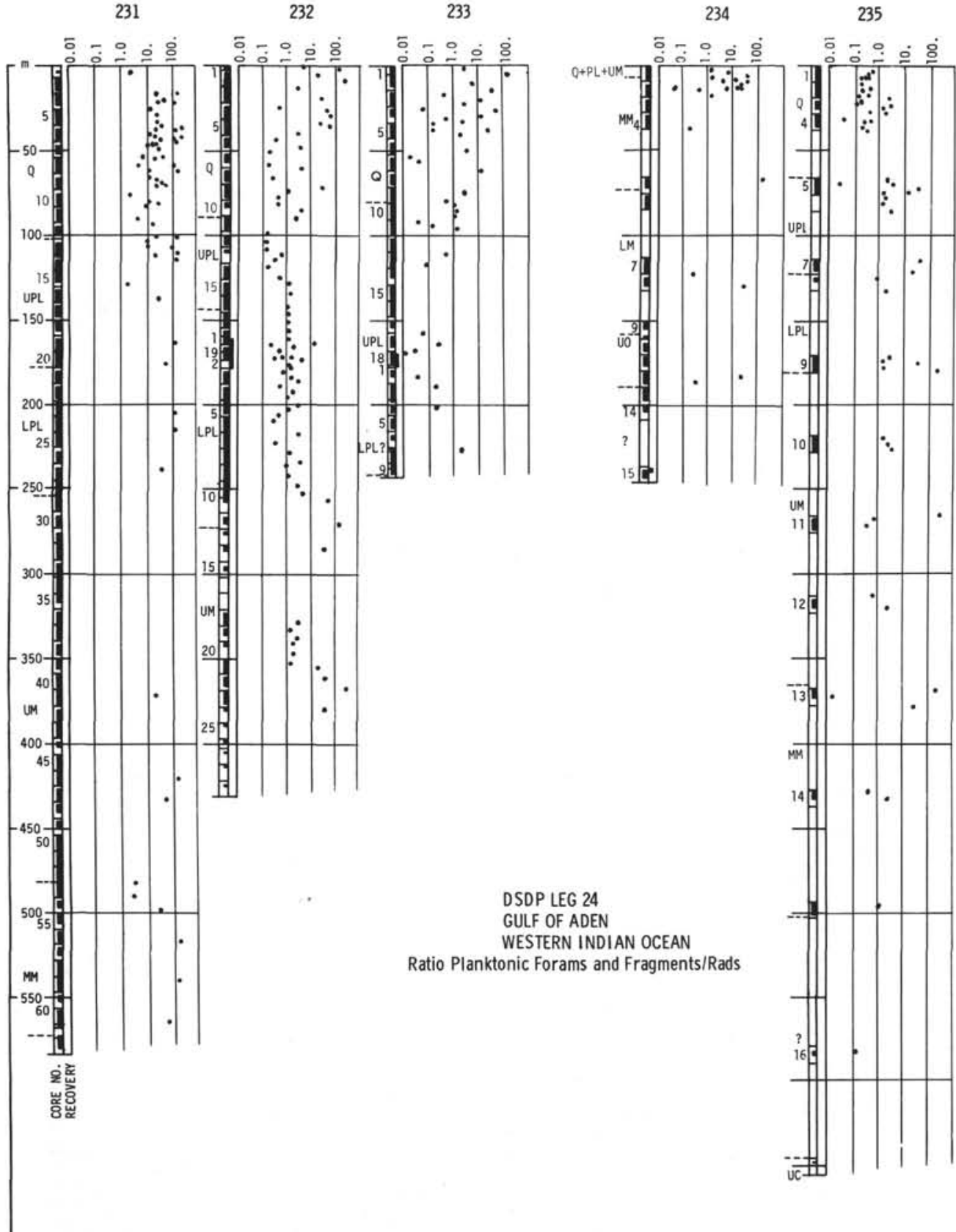

236

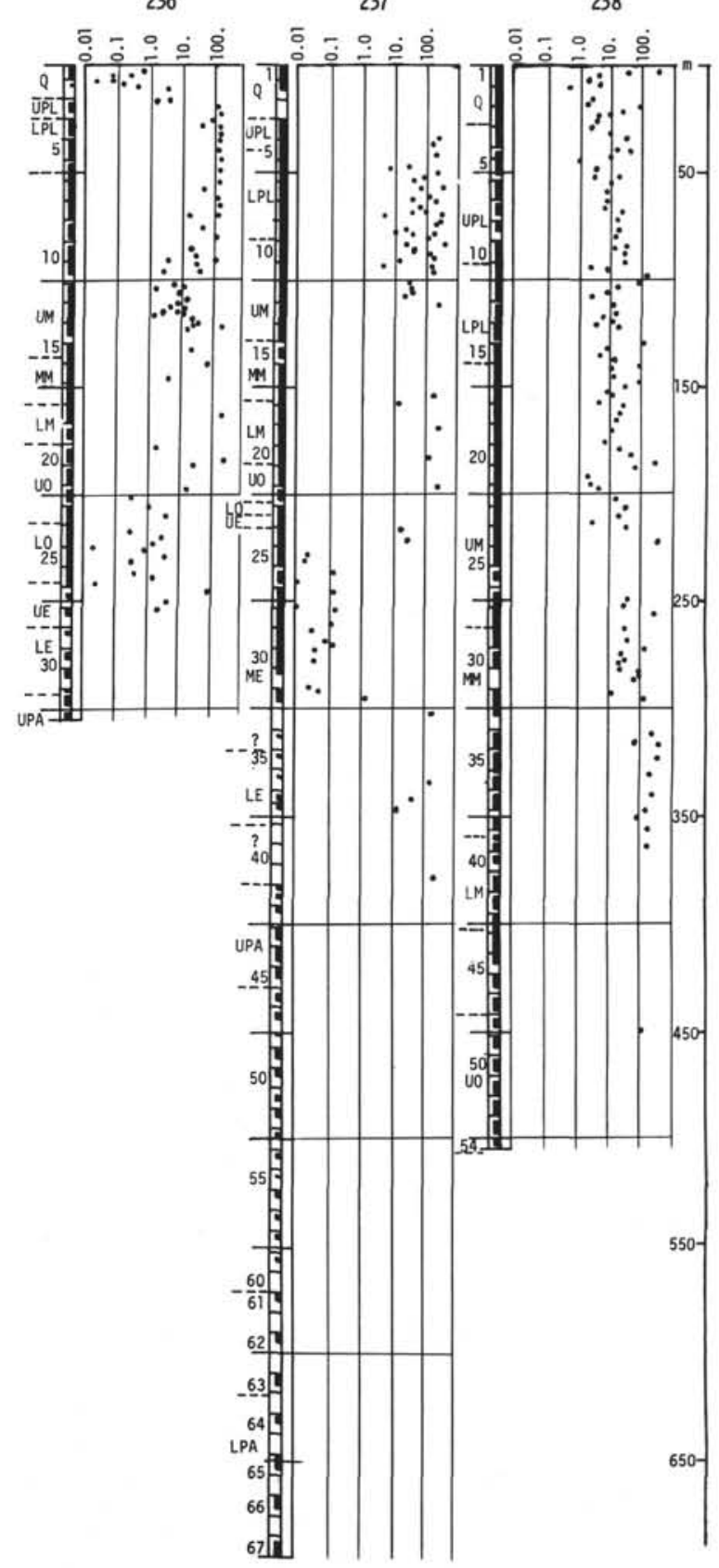

Figure 42. Ratio $=\frac{\text { Planktonic foraminifera } \text { (while tests and fragments) }}{\text { Radiolaria }}$ based on analyses of Leg 24 coarse fractions. 




Figure 43. Occurrence of benthic arenaceous foraminifera in Leg 24 coarse fractions (in percent of biogenic assemblage). Each sign indicates frequency in one sample. Samples without arenaceous benthic foraminifera are omitted. 
231

232



233

234

235

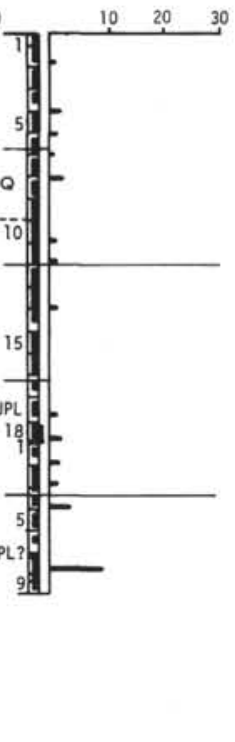

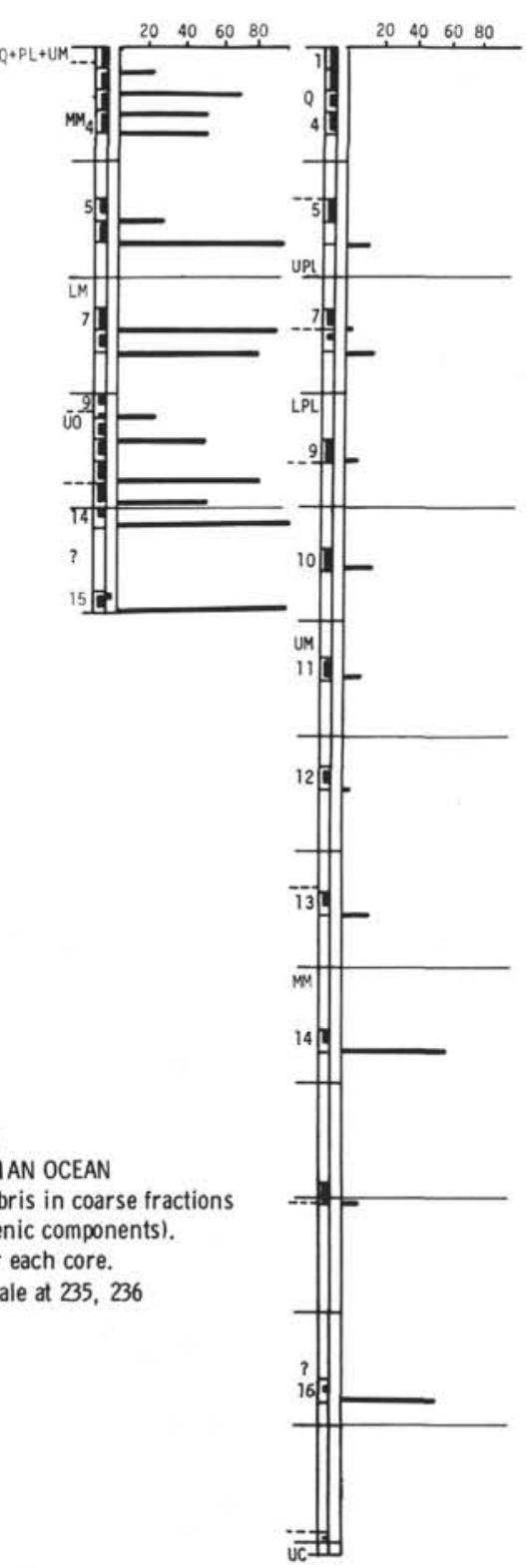

DSDP LEG 24

WESTERN INDIAN

Distribution of fish debris in coarse fractions

(in percent of biogenic components).

Average values for each core.

Remark: different scale at $\mathbf{2 3 5}, 236$ coincident with bad preservation of calcareous components.




and the upper Oligocene to middle Miocene sediments of 236. However, they also occur more frequently than usual at Sites 231, 232, and 233. The dissolution of other components is not as important here as the high organic production of this fertile area. A careful mapping of the actual sedimentation rate of fish debris would presumably depict areas of higher fertility in the ocean, especially areas of oceanic upwelling.

\section{Shallow-Water Biogenic Components}

Although consisting of a wide variety of chemical substances and being produced by very distinct organisms, these components have a common source area in rather shallow water (Figure 45). The result is not only that they are alien to the pelagic deep-water environment, but also that they are accompanied by an assemblage of normal oceanic biogenic components which are only distinct from the autochthonous components by their stage of preservation. Reworked sediments are more common in the deep sea than previously thought, and the determination of the proportion of reworked allochthonous and of autochthonous components in the sediments is of utmost importance. Primary indicators for the solution of this problem, at least in the area bordering continents and islands, are the following biogenic components (as used in this chapter).

Calcareous algal crusts are restricted to very shallow depths along the coast (especially in tropical arid areas) or to very shallow areas in the ocean such as islands or banks. They were found in horizons in Paleocene sediments at Site 237 and in horizons at Site 231 which contain a high portion of displaced material.

Plant remains presumably of continental origin have been frequently found in the Gulf of Aden sites and in the Somali Basin (but only east of Chain Ridge) and in upper Miocene sediments at Site 236. However, they are not very good indicators of shallow-water-derived material because when wet, they are easily suspendable in water, and this results in their widespread occurrence rather far from land. They are therefore not used here extensively. In the Gulf of Aden sediments they are scarce in pre-upper Miocene sediments, but increase in abundance through upper Miocene, Pliocene, and Pleistocene, becoming rare again in surface deposits. The peak in plant accumulation in sediments at Site 232 during the upper Miocene seems difficult to explain since usually plant debris requires fluvial transport to the sea (Sarnthein, 1971). This does not correlate with the occurrence of Miocene evaporites, which require highly arid conditions in the Red Sea. The rather high abundance of plant debris in the eastern and not the western part of the Somali Basin poses a serious problem which needs explanation.

A thin horizon of shallow-water Discocylina in the Paleocene of Site 237 should be especially noted. Fragments of bryozoans and corals have been found at Sites 231 and 236. Benthic molluscs (bivalves and gastropods) occur in sediments at Sites 231, 232, 233, 235, and 236.

The association of pteropods and mollusc larvae with the above-mentioned shallow-water-derived components is easily understood because of their susceptibility to dissolution in deeper waters. Stubbings (1939) mentions that the coastal sediments from 0 to 150 meters of water in the Gulf of Aden are virtually pteropod free, but their maximal occurrence lies below $150-400$ meters. For benthic molluscs, maximum abundance at 200 to 400 meters of water suggests that the bulk of the shallow-water-derived material comes from these water depths. Certainly for algal crusts, and possibly for corals and bryozoans, a shallower source area is necessary.

The ratio of planktonic to benthic foraminiferal shells has been used many times for the determination of paleowater depths (Grimsdale and Morkhoven, 1955). This ratio has also been calculated for samples of the Leg 24 sites in a hope to gain some information about possibly displaced foraminiferal faunas (Figure 46). Only the abundance of whole tests of planktonic foraminifera and benthic calcareous foraminifera has been used for the calculation of this ratio. Fragments of planktonic foraminifera are excluded because of the difficult and uncertain estimation of whole tests from fragmented faunas. Arenaceous benthic foraminifera have not been taken into account for the ratio because of their erratic preservation pattern. This ratio has been shown to be highly variable at all sites with the exception of Site 238 where it increases very slowly downwards from about 100 in surface sediments to 200-500 in the lower Miocene/upper Oligocene sediments. Since the variations of this ratio are almost parallel to the degree of calcium carbonate dissolution, it is assumed that it is almost entirely controlled by the greater resistance of calcareous benthic foraminifera to calcium carbonate dissolution. The smallest value of this ratio occurs in the Somali Basin sediments, thus showing exactly the reverse result than that expected from former studies (Grimsdale and Morkhoven, 1955; and many others). This does not apply to horizons of shallow-waterderived material which usually contain more benthic foraminifera and thus smaller ratios than the autochthonous sediment.

\section{PRESERVATION OF CALCAREOUS FOSSILS}

It has already been stated that the study of preservation of calcareous material in deep-sea sediments is of utmost interest. The roughly horizontal pattern of the distribution of solution facies (Berger, 1968) is one of the few tools available in the open oceans to determine if sediments are displaced. Displacement is most easily established by the presence of shallow-water components. However, these components are scarce and do not have easy access to deeper basins of deposition. Preservation patterns of siliceous skeletons are not as clearly depth related as those of calcareous material.

In this study, the degree of fragmentation of the ubiquitously occurring planktonic foraminifera has been taken to determine the degree of preservation of calcareous material (Berger, 1968, 1971; Berger and von Rad, 1972). A ratio of unfragmented tests to fragmented ones was expected to be depth related and therefore to offer information concerning paleodepths. It was unlikely that this could be determined using other methods because the Leg 24 sites in the Indian Ocean were situated either well below or well above the calcium carbonate compensation depth, while the sediments of the Gulf of Aden were deposited close to or on the continental margin, which has 


group are omitted). 
231

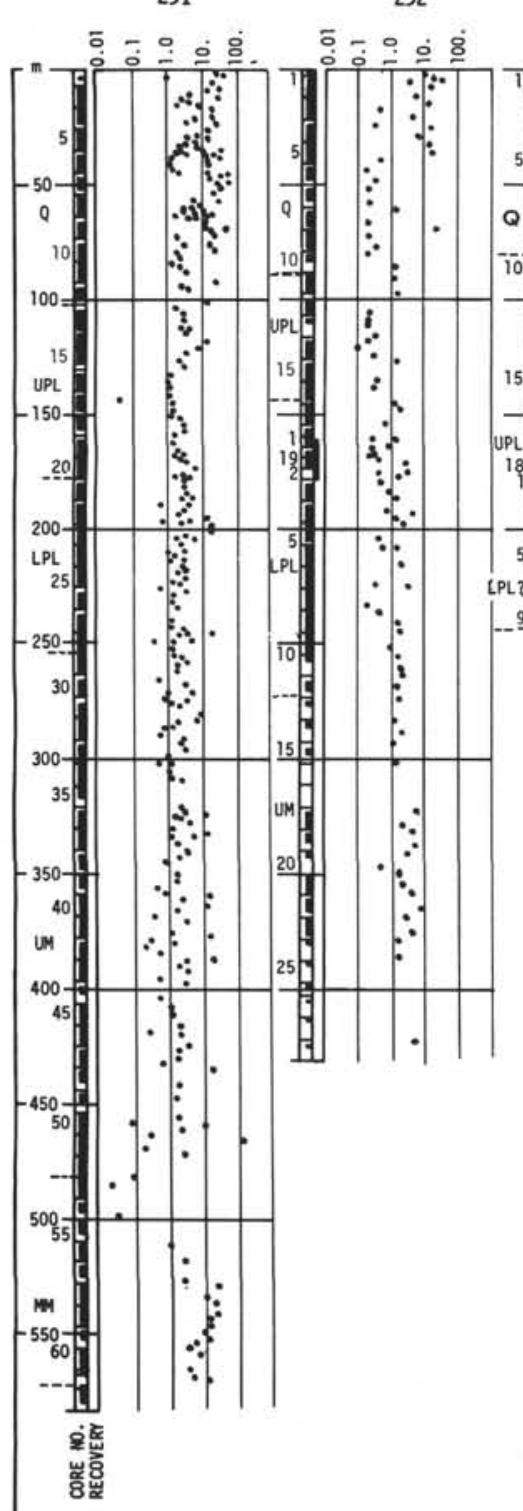

233
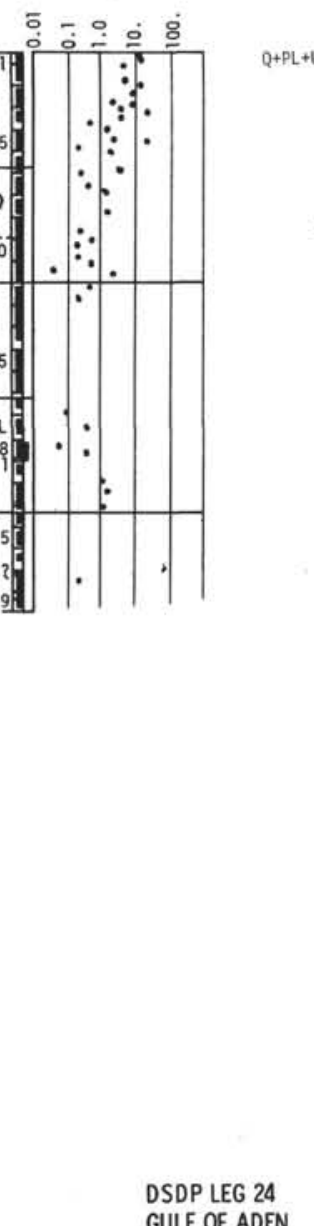

WESTERN INDIAN OCEAN

Ratio Planktonic/Calcareous Benthic Forams
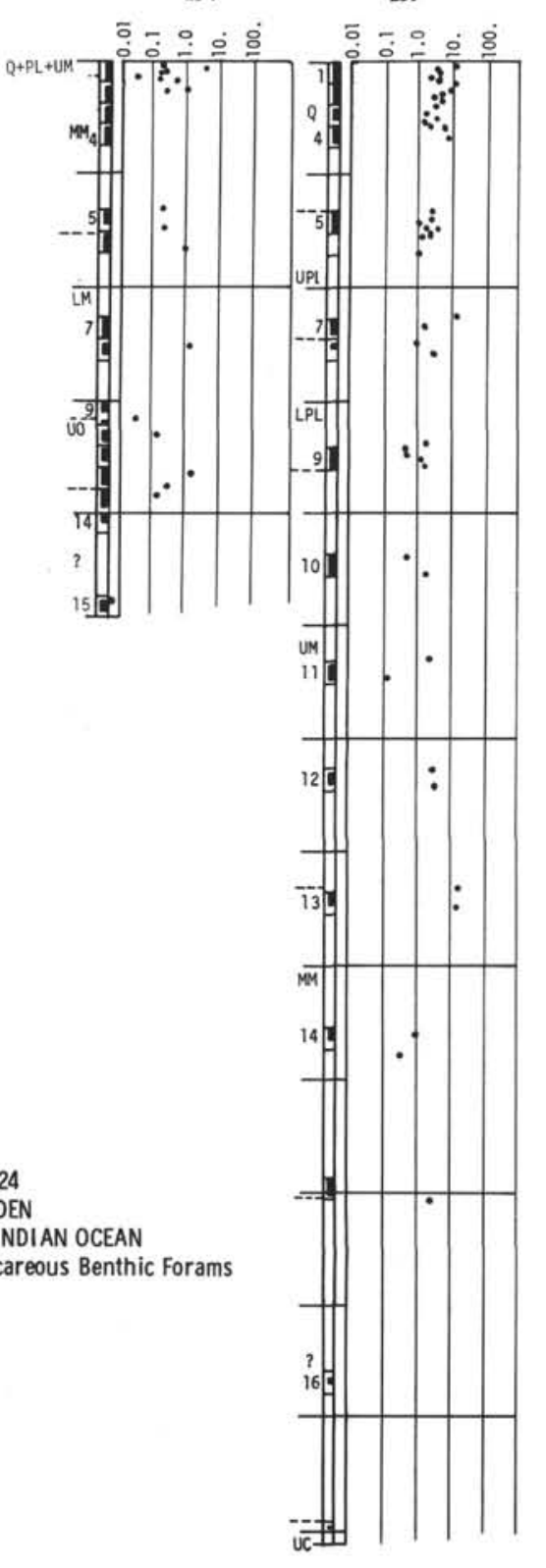

235

-7.



Figure 46. Distribution of ratios $R=\frac{\text { Planktonic foraminifera } \text { (whole tests) }}{\text { Calcareous benthic foraminifera }}$ in Leg 24 coarse fractions.

Figure 46. Distribution of ratios $R=\frac{\text { Planktonic foraminifera }(\text { whole tests) }}{\text { Calcareous benthic foraminifera }}$ in Leg 24 coarse fractions.

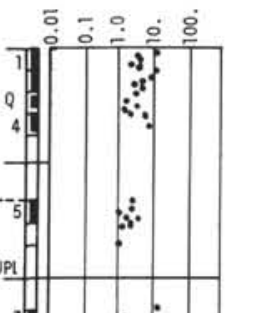

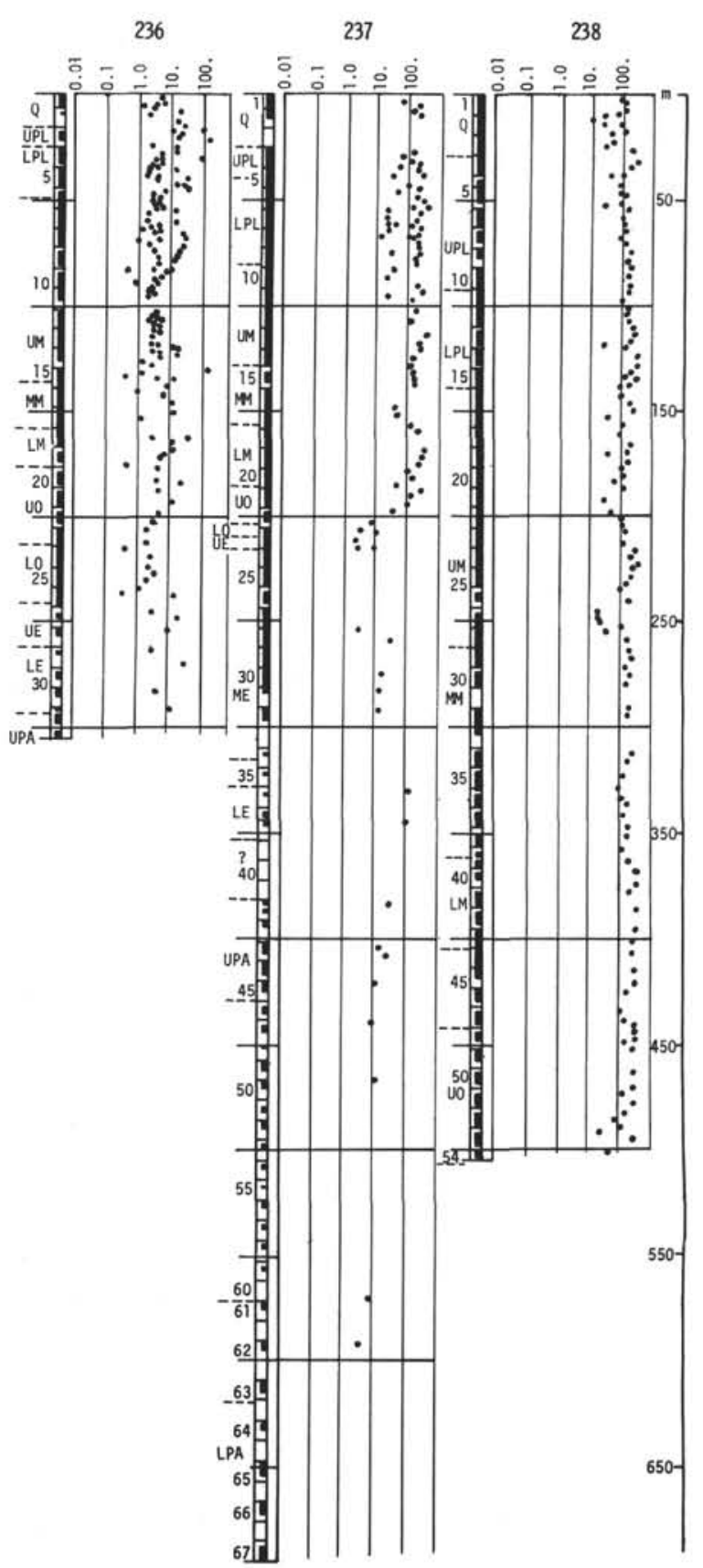


its own pattern of calcium carbonate preservation (von Stackelberg, 1972; Thiede, 1973a).

The ratio

$$
\mathrm{R}=\frac{\text { planktonic foraminifera (whole tests) }}{\text { fragments of planktonic foraminifera }}
$$

is directly dependent on water depth, as shown in Figure 47. It thus offers a rough method for approximating depth of deposition of a calcareous pelagic deep-sea sediment. This method is valid only in the open ocean because calcareous material is less well preserved in hemipelagic deposits which have a high organic content. Because of this, the values from the three Gulf of Aden sites are considerably smaller than would be expected from this curve (Figure 47). This ratio was calculated for all samples investigated (Figure 48) and conclusions were drawn despite a considerable scatter in the values of the ratio. In the Gulf of Aden, the Pleistocene and Miocene sediments generally are better preserved than Pliocene sediments. Despite its greater water depth, Site 235 in the Somali Basin shows better preservation, according to the ratios, than Site 234. The considerable scatter of values at Site 236 obscures any clear trend. At Site 237, Paleocene/lower Eocene and upper Eocene/lower Oligocene faunas are more poorly preserved than sediments of other ages. In general, the ratios at Site 238 increase with increasing depth below the sea floor.

A primary problem is to determine the reasons for the large value scatter. In calculating average values for the cores (Figure 49), it was found that although the general trend at Site 238 was easily recognizable, a number of cores contained sediment from shallow-water depths which were characterized by better preservation of the calcareous sediment than was indicated by the water depth of deposition of the surrounding sediment. This conclusion is substantiated by the Site 236 samples, where a number of coarse horizons clearly contain a small proportion of shallow-water components. In Figure 49 at Site 236, the coarse-grained horizons have been excluded, but still the finer sediment showed similar inconsistencies. This phenomenon was observed at nearly all sites and we therefore have concluded that almost all deep-sea oozes and chalks obtained at these localities consist not only of autochthonous sediments, but also of great proportions of displaced sediment (Parker, 1971). Calculation of the depth of origin of the Site 236 coarse horizon shows an average water depth of 3000 meters despite the presence of shallow-water-derived material. Considerable mixing of sediments is therefore probable.

In Figure 50a-d, the preservation of the planktonic foraminiferal faunas at Sites 231, 232, 233, and 237 is shown. The Gulf of Aden sites, again show better preserved Pleistocene and Miocene than Pliocene sediments. Site 237, from about a similar water depth in the open Indian Ocean is considerably different.

Paleodepths can be calculated from these values for all sites which lie well below or well above the range of fluctuation of the calcium carbonate compensation depth. This has been done provisionally for all sites except the Gulf of Aden Localities (Figures 51a-e), without taking into account fluctuations of the calcium carbonate compensation depth. Using these figures, former water depths derived



Figure 47. Preservation of planktonic foraminiferal shells, illustrated by the

Ratio $=\frac{\text { Planktonic foraminifer }(\text { whole tests })}{\text { Fragments of planktonic foraminifera }}$.

Values

based on surface sediments of Leg 24 sites, crosses

based on data taken from Belyaeva (1970).

from the hypothesis of age/depth constancy (Sclater et al., 1971; Berger and von Rad, 1972) were calculated where basaltic basement had been reached and a reasonable age for the basement determined (Figures 52 and 53).

Sites 234 and 235 are both characterized by foraminiferal preservation which indicates water depths 1000-2000 meters shallower than at present. It must therefore be assumed that the proportion of displaced sediments is very great in the basin.

Site 236 clearly reveals two distinct zones. $\mathrm{CaCO}_{3}$ preservation at the base of this site (Paleocene) is consistent with former water depths based on the age/depth constancy curve. However, the ratios drop considerably in Eocene sediments (between about 40 and 50 m.y.) and reach the level (or slightly above) of expected values at about lower Oligocene and then drop slowly to the present values. The computed former water depth is based on the preservation of foraminifera in individual horizons considerably above the age/depth constancy curve and is a measure of the input of displaced sediments. The parallel occurrence of very deep water computed for a time of reduction in spreading or possibly no spreading (Fisher et al., 1971) is probably not coincidental. The curve might really reflect a crustal oscillation.

Foraminiferal preservation in Site 237 sediments offers the reverse of what was expected: shallow water depth during the Paleocene and Eocene with sinking occurring afterwards. Foraminiferal preservation, however, does not agree with this. Computation tells us that the site was situated in deep water (about $4000 \mathrm{~m}$ ) until lower Oligocene and was sequentially uplifted. The presence of the shallow-water-derived components can be explained as a result of slumping. However, foram evidence is more difficult to explain, because samples indicating deep water might be winnowed, resulting in a relative enrichment of foram fragments, and hence computation of a greater water depth (compare Vincent et al., this volume). 
231
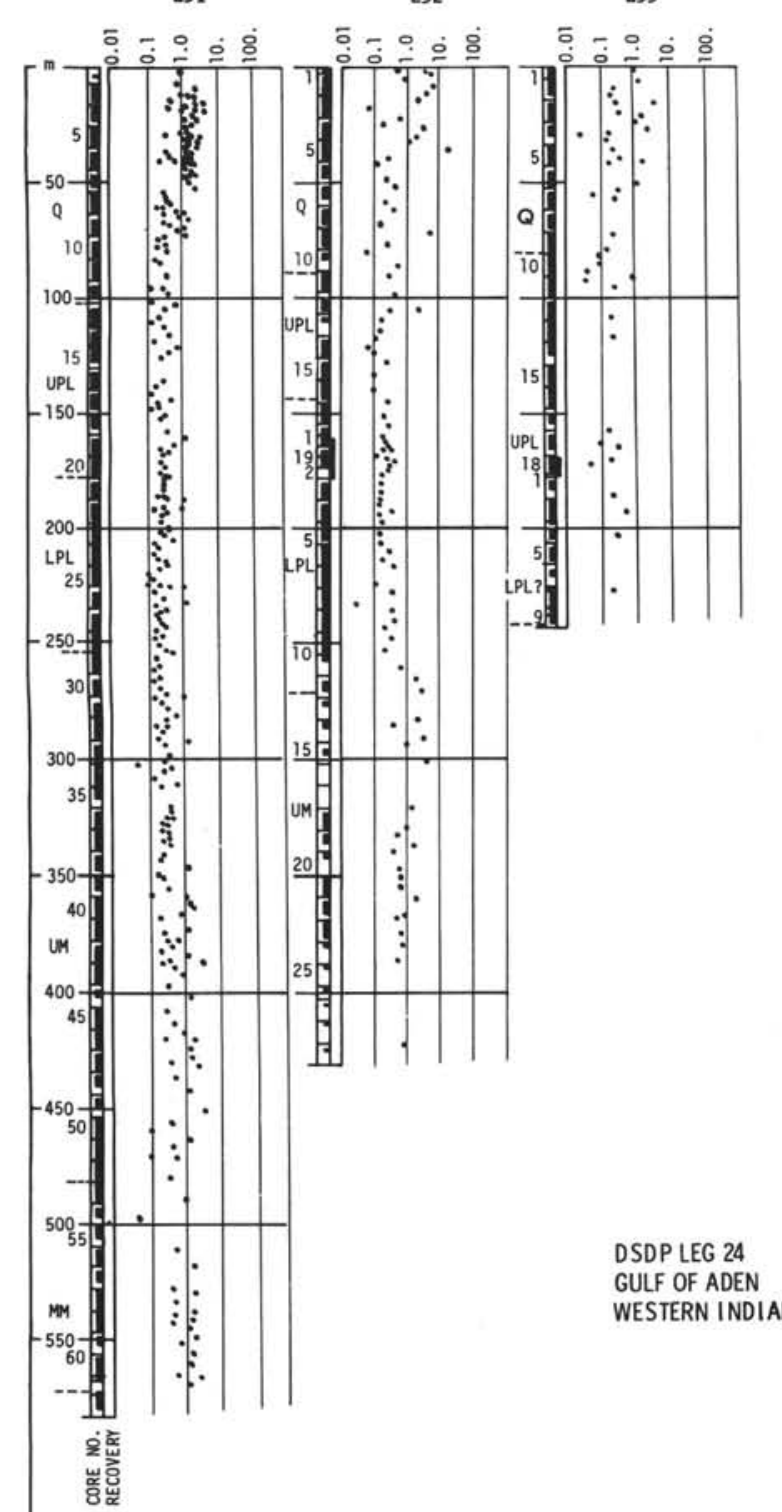

234



DSDP LEG 24

WESTERN INDIAN OCEAN



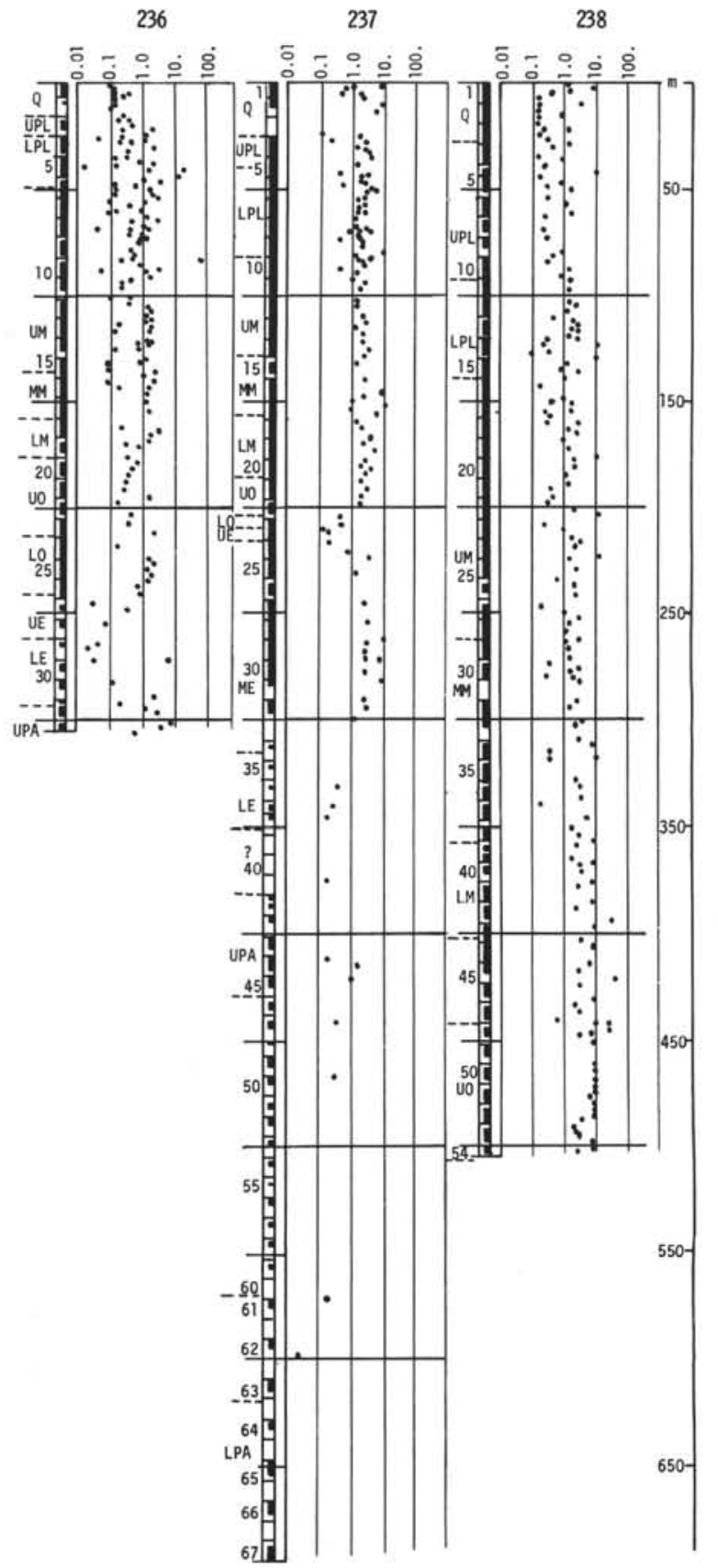

Figure 48. Preservation of planktonic foraminiferal faunas in Leg 24 sites, expressed as Ratio $=\frac{\text { Planktonic foram (whole tests) }}{\text { Fragments of planktonic foram }}$ 

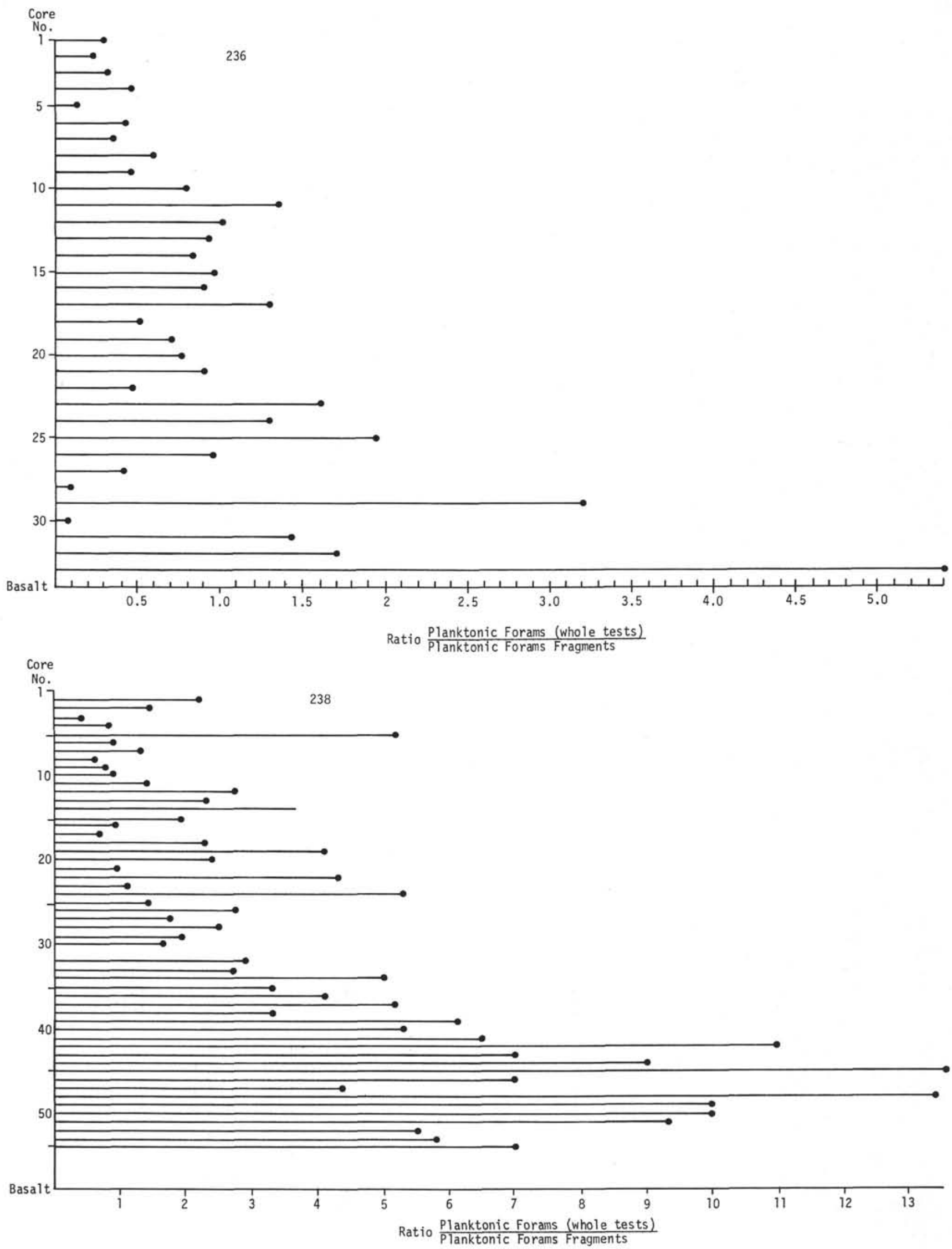

Figure 49. Fragmentation of planktonic foraminiferal shells in Site 236 and 238 sediments. Average values for each core in Site 238, average values for fine grained sediments $(<15 \%$ sand sized material in Site 236). 
The best correlation between computed and expected water depth was found for Site 238 , although the values are too high in the older part of the curve and too low in its younger part. It also means that, for this site, fewer fragments were found than expected close to the ridge (old sediments) and excess fragments were found far from the ridge (young sediments). This positive anomaly close to the ridge can be explained by the removal of fragments, the negative anomaly might, however, either be due to the contribution of fragments or to the removal of whole tests. It does not seem coincidental that the computed paleowater depths for displaced sediments at Sites 234, 235, and 236 usually lie between 2000 and 3000 meters, exactly the range of this negative anomaly. Probably the source of displaced sediments in this area has to be sought in these water depths.

The determination of the position of the calcium carbonate compensation depth and the foraminiferal lysocline is of utmost importance. Site 236 alone was suitable for determining the position of the calcium carbonate compensation depth which was found to have been just below 4000 meters in lower Miocene times, somewhat deeper than indicated by Berger and von Rad, 1972. However, since paleodepths at this site are question- able, this problem will not be further discussed before data from all Indian Ocean sites and additional foraminiferal counts are available.

\section{AGE/DEPTH CONSTANCY AND SEDIMENTATION RATES}

In applying the age/depth constancy of basaltic oceanic basement (Sclater et al., 1971; Sclater and Detrick, 1973), to the Leg 24 drill sites, major inconsistencies are found (Figure 52). From eight sites, five reached an acoustic basement consisting of basic rocks. One of these five (Site 233) ended in a sill presumably underlain by sediments. The other four sites which penetrated the sediments down to the basaltic basement show a considerable scatter around the hypothetical curve (Figure 52).

Since these values are based on the age of the oldest sediment, it is possible to explain that a position below the age/depth constancy curve might be due to a stratigraphical gap between the basalt and the oldest sediment, the underlying basalt being considerably older (for example, Site 235). The position of a site considerably above the curve is much more difficult to explain.

Site 236 is situated on old oceanic crust which possibly was uplifted when spreading started after a period of no or



Figure 50a. Preservation of planktonic foraminiferal faunas in Site 231. Minimum and maximum values are indicated: average ratios in coarse layers per core ( $>15 \%$ sand); $\bullet$ average ratios of all samples per core; and $X$ average ratios of fine sediments ( $<15 \%$ sand) per core. 


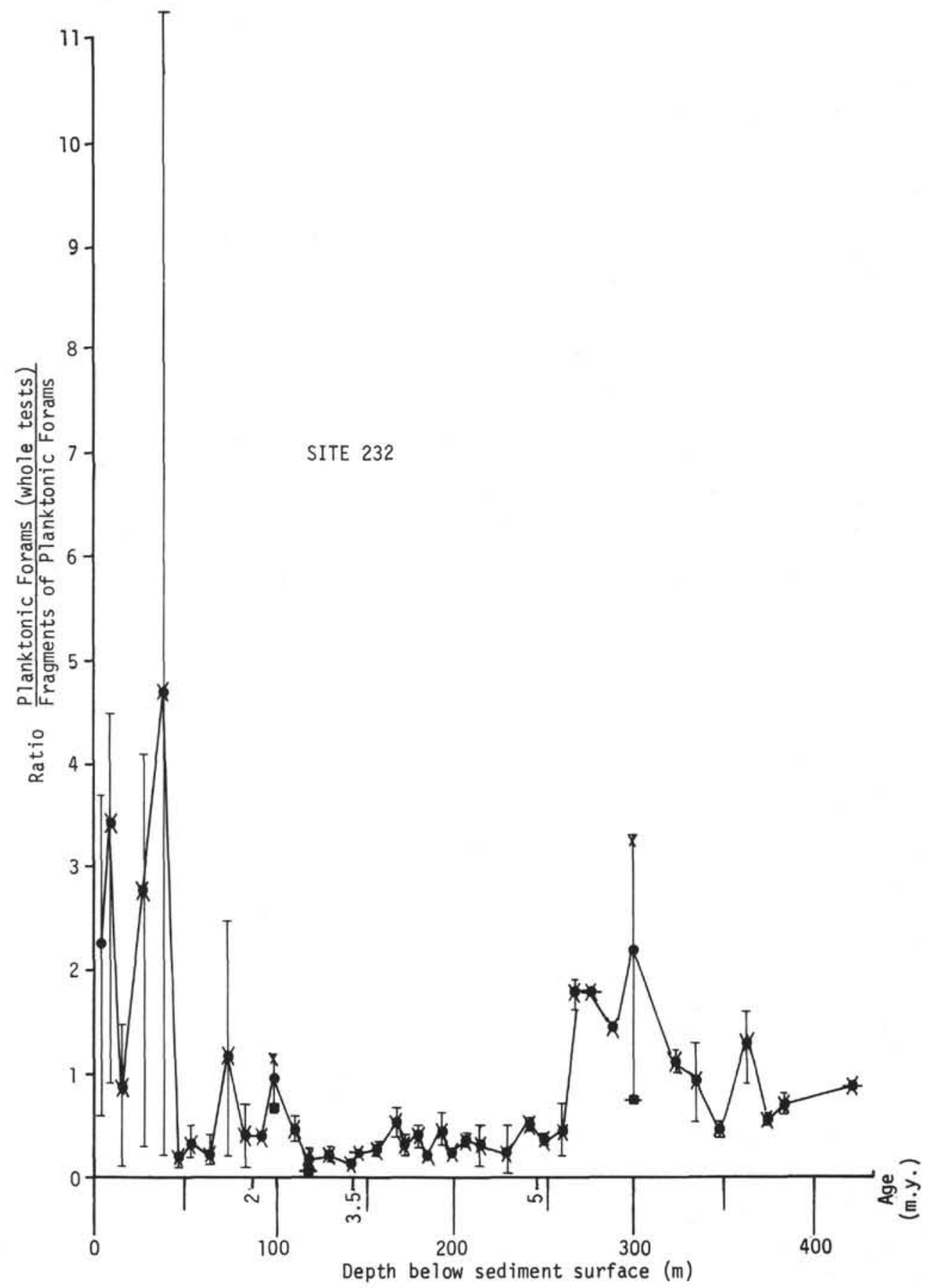

Figure 50b. Preservation of planktonic foraminiferal faunas in Site 232, See caption (Figure 50a) for minimum and maximum values. 




Figure 50c. Preservation of planktonic foraminiferal faunas in Site 233. See caption (Figure 50a) for minimum and maximum values.



Figure 50d. Preservation of planktonic foraminiferal faunas in Site 237. See caption (Figure 50a) for minimum and maximum values. 


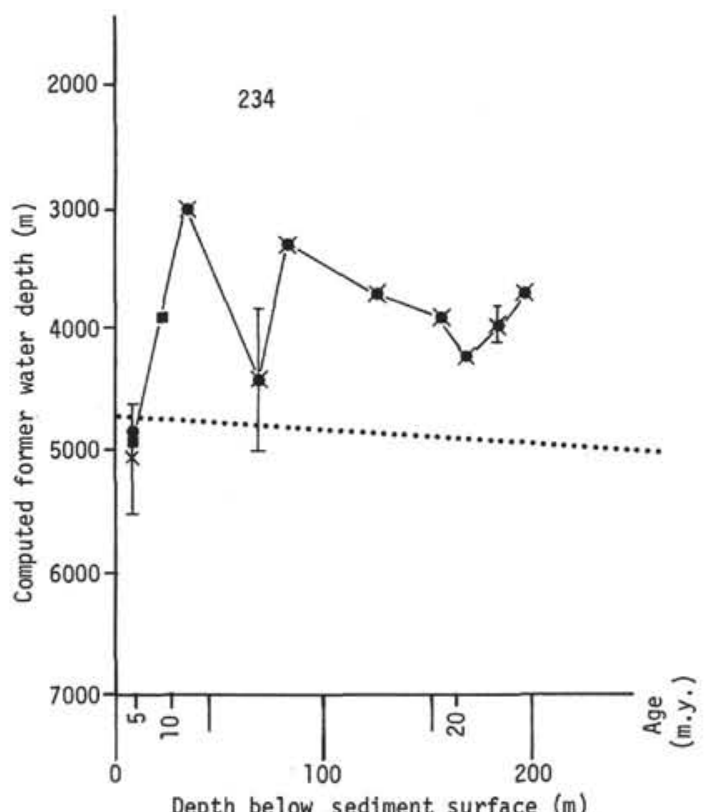

Figure 51a. Computed former water depths, Site 234. Minimum and maximum values are indicated: average of coarse sediments (>15\% sand) per core; - average of all samples per core; $X$ average of fine sediments $(<15 \%$ sand) per core; ..... present depth below water surface; ..... paleodepths based on age/depth constancy.



Figure 51b. Computed former water depths, Site 235. See caption (Figure 51a) for minimum and maximum values. 




Figure 51c. Computed former water depths, Site 236. See caption (Figure 51a) for minimum and maximum values.



Figure 51d. Computed former water depths, Site 237. See caption (Figure 51a) for minimum and maximum values. 




Figure 51e. Computed former water depths, Site 238. See caption (Figure 51a) for minimum and maximum values.

slow spreading (McKenzie and Sclater, 1971). The other two sites lie in the cleft of a transform fault (Site 238), or in an embryonic ocean basin (Site 231). This might possibly explain the elevated position of the basaltic basement. As these age/depth constancy curves are always based on smoothed topographic profiles, (for example, McKenzie and Sclater, 1971; and others) local highs of the basement would explain such an elevation of the curve although this would not be consistent with the character and presence of the sediments described here.

Figure 54 shows the reconstruction of former water depths. This has been tried for all Leg 24 sites, where true basaltic, oceanic basement was reached. Corrections for local topography and the sediment load have been taken into account (Berger, 1973; van Andel and Bukry, 1973). Oscillations of the oceanic crust due to shifts of the spreading axis are especially problematic for this kind of reconstruction. Except for Site 235, the figures are based on only one phase movement although this is presumably not correct (especially for Site 236).

The rate of subsidence also has an effect on the sedimentation rates (Figure 55a,b). In part a of this figure, sedimentation rates are calculated to be equivalent to the subsidence rate of a newly formed oceanic crust (effects of a sediment load have not been taken into account). The curve defined by these sedimentation rates is a boundary between two different sedimentary environments. If the actual sedimentation rates at a site are below this curve, only normal pelagic sediments and displaced material from the ridge can be expected; if the sedimentation rates are above, soon no material from the ridge can reach the site and the sediment pile can only be built up by normal pelagic sediments and displaced material from outside the ridge area, in many cases continental material. However, these assumptions are only valid for the open ocean and cannot be applied to areas very close to the continental margin.

It is also important to consider only basement built up and affected by the same continuous spreading rift. Such a simple case has almost never been found in the complicated Indian Ocean, and only Sites 233 and 238 seem to follow this simple scheme. While Site 231 is situated on rather young oceanic basement very close to the continental margin, all other sites lie either on basement which has been affected several times by new spreading activity (Sites 235 , 236) or above unknown basement (regarding its nature or its age or both: Sites 232, 234, 237).

The average total sedimentation rates of all Leg 24 Indian Ocean and Gulf of Aden sites are shown in Figure $56 \mathrm{a}-\mathrm{c}$. The holes always penetrated deeper into the sedimentary sequences shown in these diagrams, but only the parts with well-defined upper and lower stratigraphic boundaries were taken into account.

In general, several patterns of sedimentation rates are not well understood in terms of the preceding discussion. Shallow-water-derived (not from the ridge area) material occurs in the following Sites: 231, 232, 233, 235, 236 (indicated by a cross in the diagrams of Figure 56). This means that the greatest input of shallow-water material has occurred in the Indian Ocean and the Gulf of Aden since uppermost middle Miocene time (Figure 57a). The coincidence of shallow-water material in sites with rather young basement is poorly understood, but might be a regional pattern in the Indian Ocean and adjacent seas.

In correlating the first occurrence of shallow-water material (expressed in terms of age) with the sedimentation rates of deposits they have been found in, it is obvious (Figure 57a) that the sedimentation rates for the sites on 


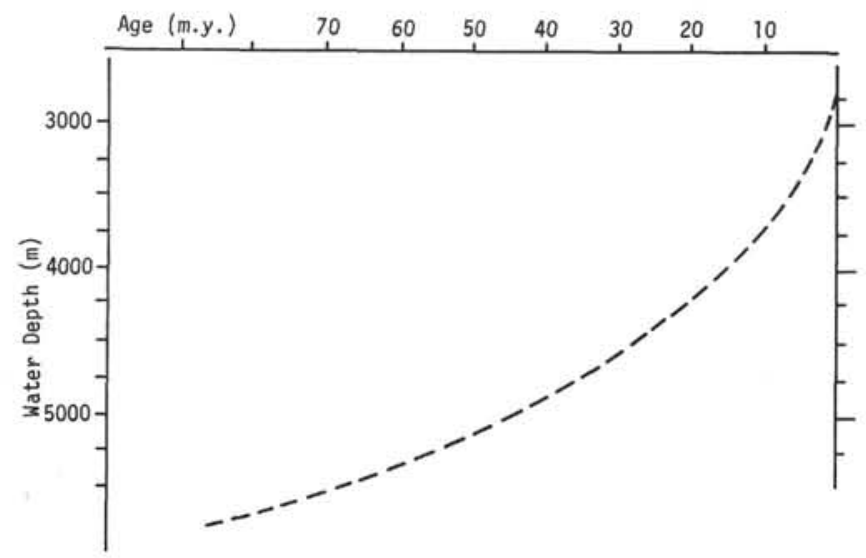

Figure 52. Depth of present sea floor as a function of its age, taken from Berger (1972). This curve is only valid for "old" oceans, for open oceanic environment, for areas not affected by transform faults, guyots and ridges.

young basement are far from reaching the minimum sedimentation rates which should be expected following the curve of Figure 55b. The discrepancy between the estimated minimum sedimentation rates and the values actually found is greatest for the sites on the youngest basement decreasing systematically for older basement (Figure 57b). Only negative discrepancies are of critical importance because positive ones would allow an explanation for the presence of shallow-water-derived components.

Negative values, however, virtually prohibit a transport mechanism for these components as indicated in Figure $55 \mathrm{~b}$.

There are several possible reasons for these discrepancies:

1) Estimated age of basemen is too young due to a stratigraphical gap between basalt and overlying basal sediments. This does not seem possible since the age of sediments directly above basement and the assumed ages (based on magnetic anomalies) for the basaltic basement agree rather well.

2) Because of compaction and possible changes of volume due to diagenetic processes, the present thickness of sediments does not necessarily represent the true thickness of sediments (which was probably greater). However, the discrepancies seem to be too large to be due only to compaction (see Physical Properties sections of Site Reports, this volume). Also, if this process has an important effect on sedimentation rates, it does not explain the age coincidence of this material in widely distant areas of the Indian Ocean.

3) An evident possibility to reach the present sites if sedimentation rates were insufficient to offer a transport path directly from the continental margin is indicated by the very young basement ages of Sites 231 and 233 in the embryonic oceanic basin of the Gulf of Aden. Allowing these components a way not only perpendicular to the spreading ridge, but also along the basin axis, the presence of these components may not pose such a serious problem any longer.

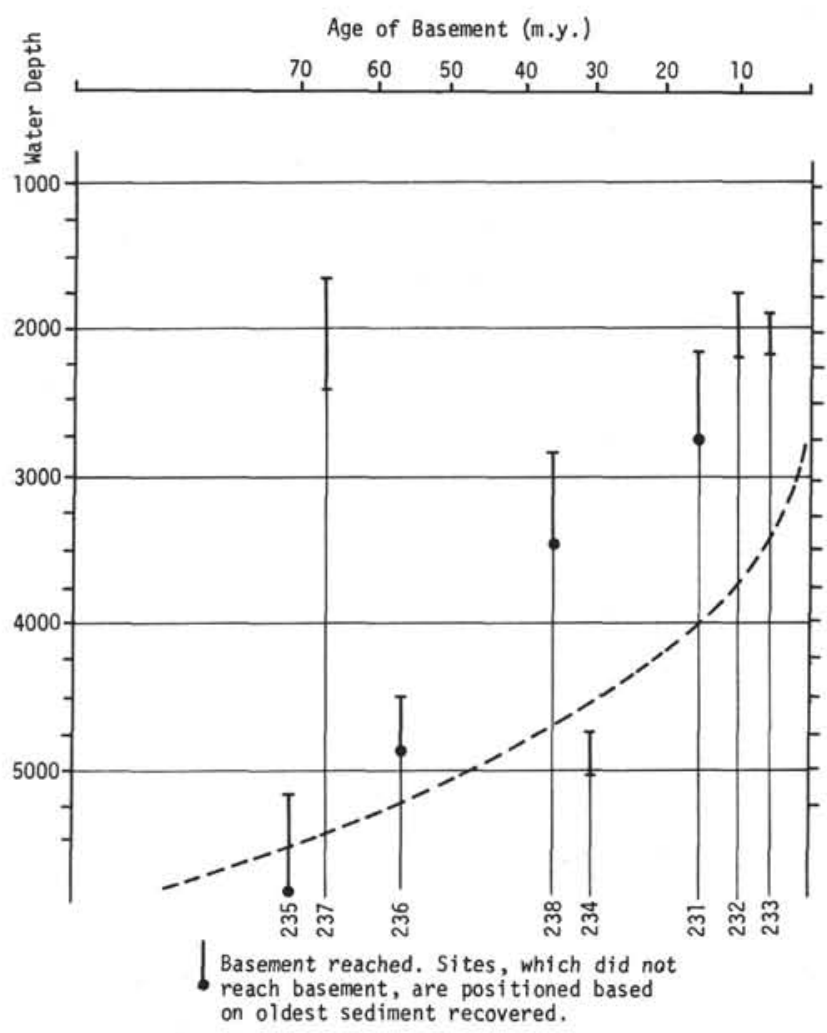

Figure 53. Positions of Leg 24 sites in the water depth/age of basement constancy diagram (compare Figure 52). Sites, which did not reach basement, have been placed on age of oldest recovered sediment.

\section{SUMMARY AND CONCLUSIONS}

The conclusions presented here are based mainly on results of the coarse fraction analysis of the Leg 24 sites in the northwestern Indian Ocean and the Gulf of Aden. A number of pending questions, which could not be resolved due to their regional character, might deserve reconsideration as soon as data from DSDP Leg 23 (Whitmarsh et al., 1972) and Leg 25 (Simpson et al., 1972) have been released. Their drill sites cover physiographic provinces adjacent to those of Leg 24 (cf. Figure 57) and are expected to bear important evidence for the source areas of the redeposited Leg 24 sediments for example.

\section{Gulf of Aden Sites}

The three sites in the Gulf of Aden cover a wide variety of sediments which range from almost entirely pelagic oozes to shallow-water quartzose sandstone. However, the bulk of these sediments must be called hemipelagic although they are considered in the text and sediment descriptions to be mostly nanno oozes due to the overwhelming dominance of calcareous nannofossils.

The sediments of the Gulf of Aden sites $(231,232,233)$ here are considered hemipelagic because:

1) They contain a high proportion and diversity of terrigenous components (wind and water transported). 

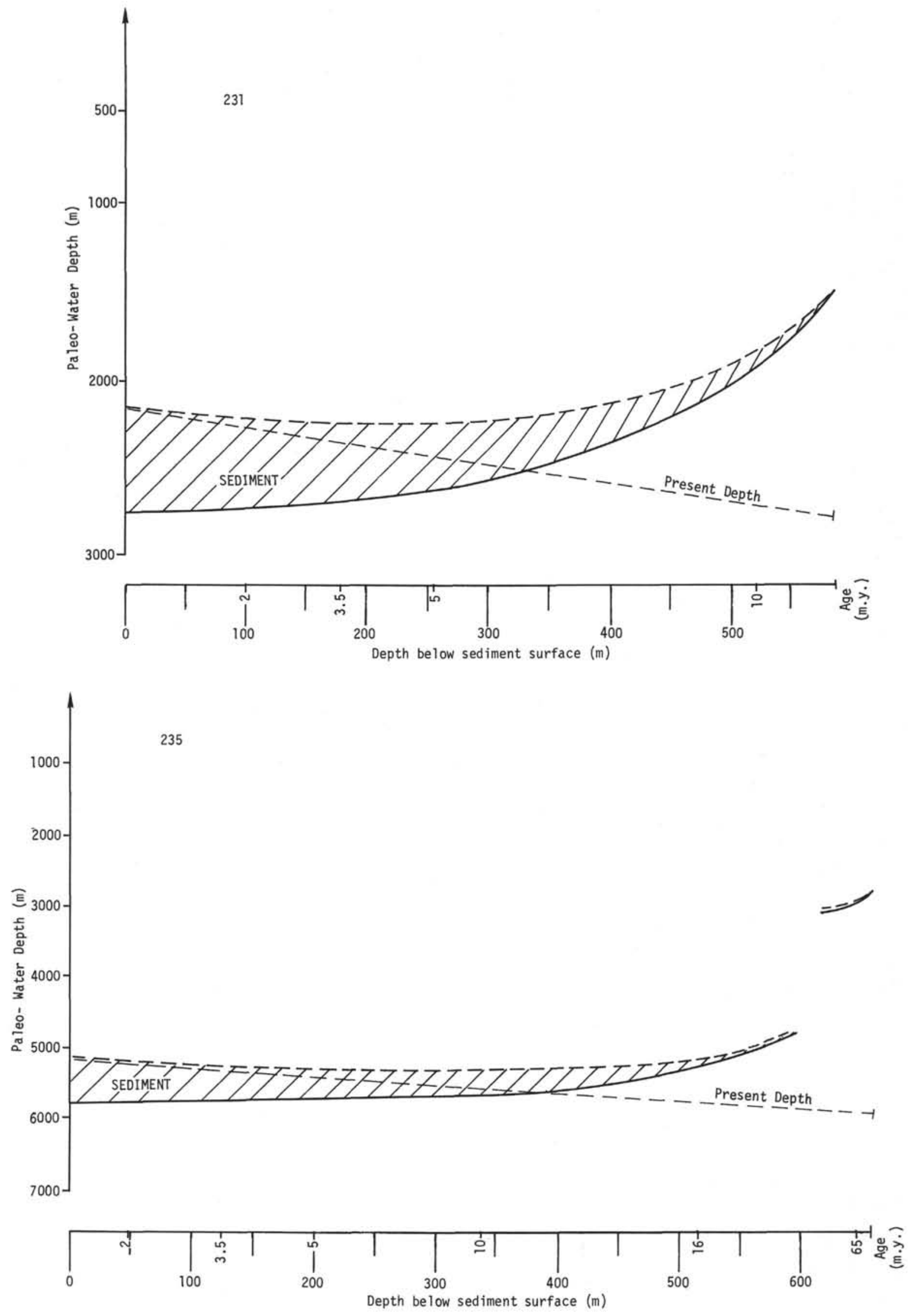

Figure 54. Reconstruction of former water depth for the Site 231, 235, 236, and 238. Truck of basement is corrected for topographic effect and load of sediments (Berger, 1973, Sclater et al., 1971). 

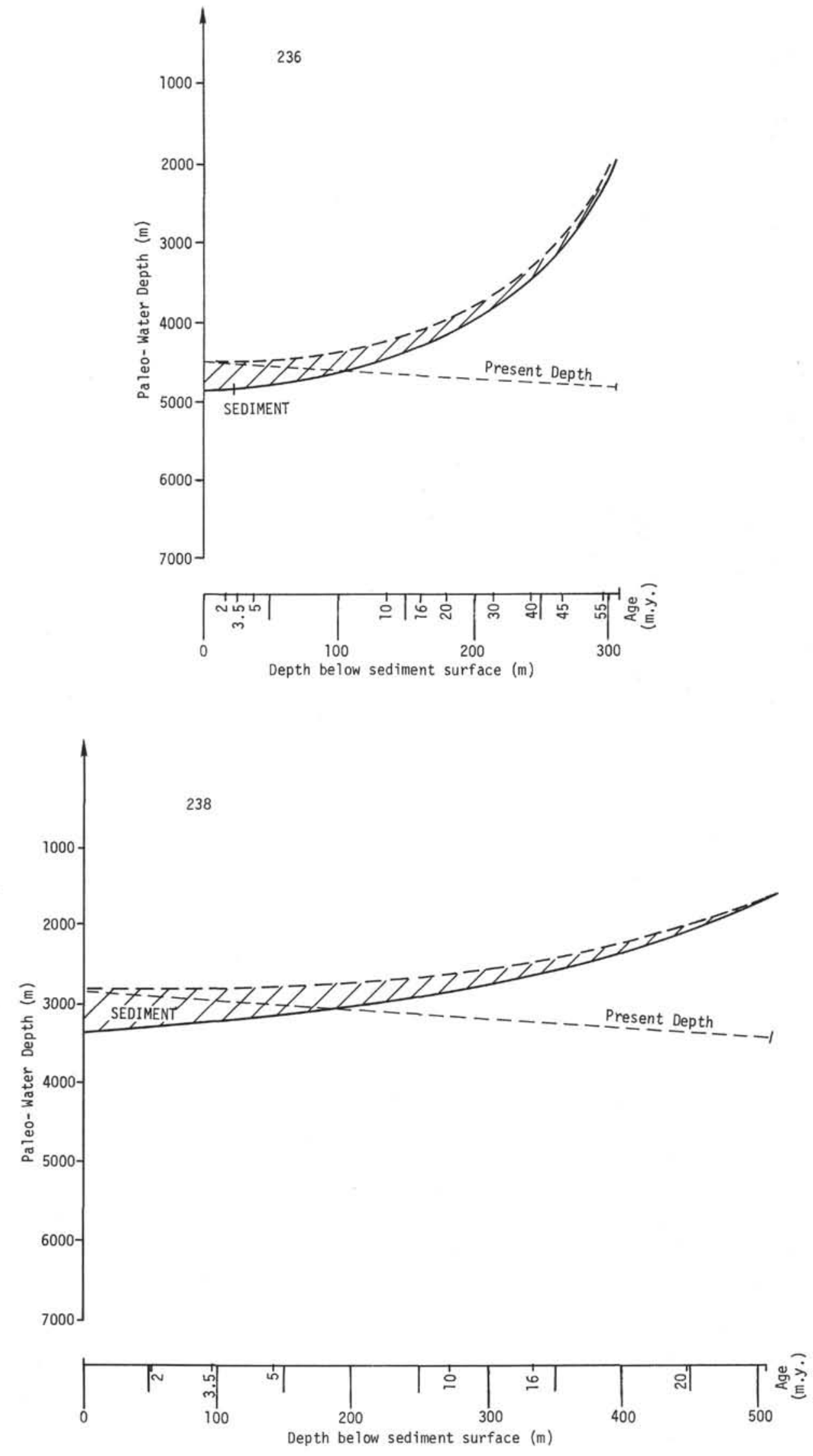

Figure 54.(Continued). 


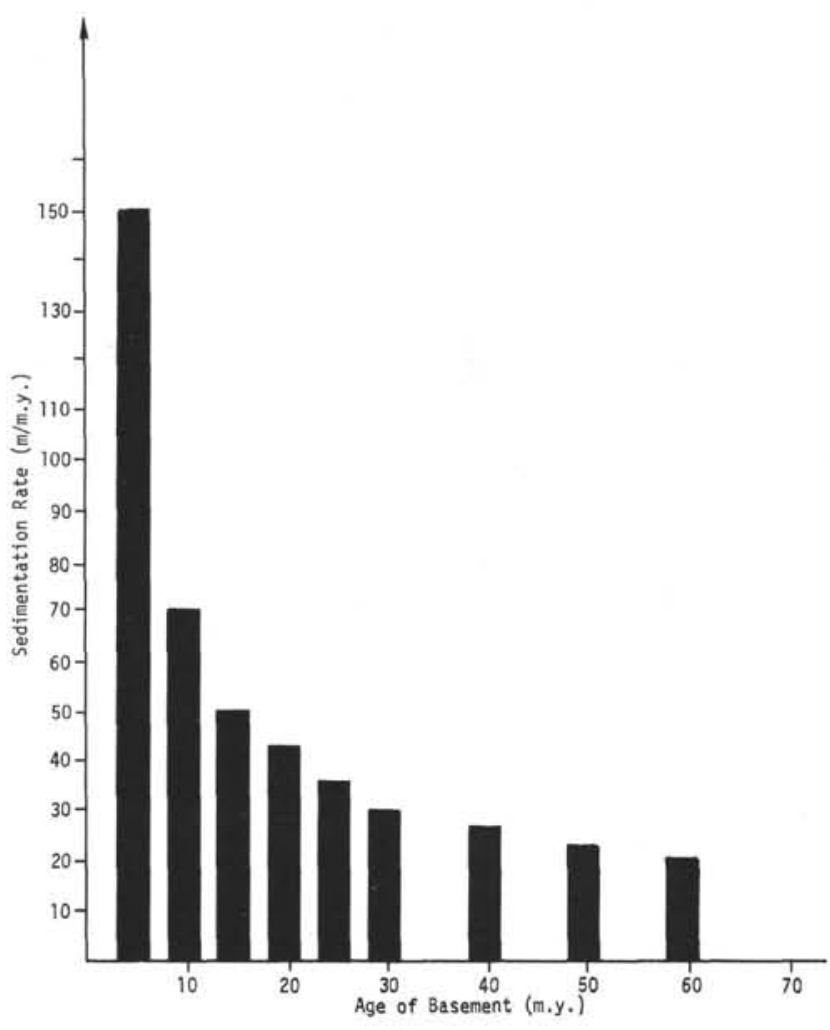

Figure 55a. Minimum sedimentation rates for the maintenance of similar water depth through time /subsidence of crust $=$ sediment accumulation).

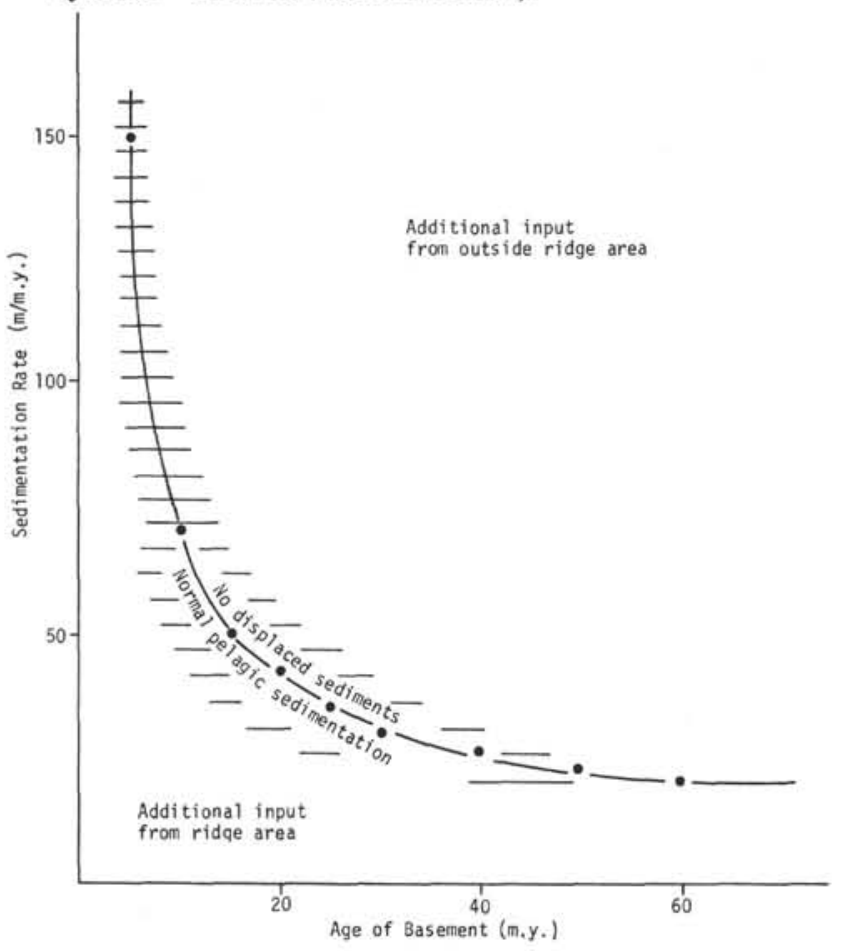

Figure 55b. Presumable source areas for displaced material depending on subsidence of crust and sedimentation rates. Only valid for suspension following topography in the open ocean and above basement of same spreading cycle.
2) There is a high organic carbon content, commonly a hydrogen sulfide odor, and patches of bitumen are present (Site 231).

3) They contain abundant authigenic minerals, especially pyrite.

4) There is a high content of shallow-water-derived material as well as pteropods and mollusc larvae in the same horizons.

5) They contain poorly preserved calcareous fossils (except in horizons with shallow-water-derived sediment), despite the fact that the water depth was not extremely great.

6) Although sedimentation rates do not change considerably (Einsele and Werner, 1968), burrows and primary sedimentary structures show inhomogeneity while the macroscopic appearance of the sediments is very homogeneous.

7) Benthic autochthonous fossils (foraminifera, echinoids) as well as remains of fishes are frequent to abundant throughout the whole sedimentary sequence which points to the high productivity of this area since the middle Miocene.

Beside these characteristics, the following features are common for all three sites:

1) The total sedimentation rates range between 40 and $90 \mathrm{~m} / \mathrm{m} . \mathrm{y}$. (Figure 56). The bulk of the sediments of these three sites consists of calcareous nannofossil ooze.

2) The calcareous fossils are better preserved during Miocene (only Sites 231 and 232) and Quaternary than during Pliocene.

3) Siliceous remains of both benthic and planktonic organisms have revealed a similar distribution pattern (they are bonded to the fine-grained parts of the sedimentary column and thus are not redeposited), suggesting that this pattern is likely due to differential preservation.

4) Plant debris occurs ubiquitously at all sites, but is especially enriched in uppermost Miocene at Site 232. Otherwise, its abundance decreases generally from Sites 231 to 233 .

5) The composition and preservation of the shallowwater-derived material are very unhomogeneous suggesting distinct source areas.

Almost 600 meters of middle Miocene to Recent sediments overlie oceanic basaltic basement at Site 231 . The sediments directly above basaltic basement are truly hemipelagic without any shallow-water input suggesting that a small but well-developed oceanic basin with a centrally elevated ridge already existed in middle Miocene times (Figure 59).

A terrigenous, presumably airborne, fraction occurs in all samples. Its characteristic components are quartz, mica, dolomite rhombs, and few other mineral grains. Its grain size is in the lowermost range of the sand fraction. Since material $>63 \mu$ comprises only a few percent of the total, it seems reasonable to assume that the bulk of the windtransported material has not been examined here due to its finer grain size (Füchtbauer and Müller, 1970).

Quartz/mica ratios may depend strongly on water and wind transport, since they are always much higher in coarse horizons with shallow-water-derived sediments. In general, quartz/mica ratios have decreased since upper Miocene 


\section{J. THIEDE}

(Figure 10). This might be a good indicator for the increasing size of the Gulf of Aden (Figure 59).

The terrigenous components which occur together with shallow-water fossils consist of big (up to $0.5-1.0 \mathrm{~mm}$ ) rounded and polished quartz grains, mica, rock fragments, and reworked older fossiliferous sediments. Coarse-grained layers with high proportions of shallow-water-derived components (rock fragments and reworked older fossiliferous sediments, benthic molluscs and their larval stages, pteropods all associated with higher quartz/mica ratios) are frequent in Pliocene and Pleistocene sediments. The occurrence of shallow-water-derived components in older and in more fine-grained sediments as well, precludes a purely paleoclimatic interpretation for this continuous detrital input from the shelf or upper continental slope (Figure 9). The composition and preservation of the shallow-water-derived material is inhomogeneous which suggests several source areas. Conversely, the bulk of the fine-grained terrigenous clastic grains is very homogeneous in composition.

The bulk of the sedimentary components are biogenic and pelagic in origin. Planktonic foraminifera are better

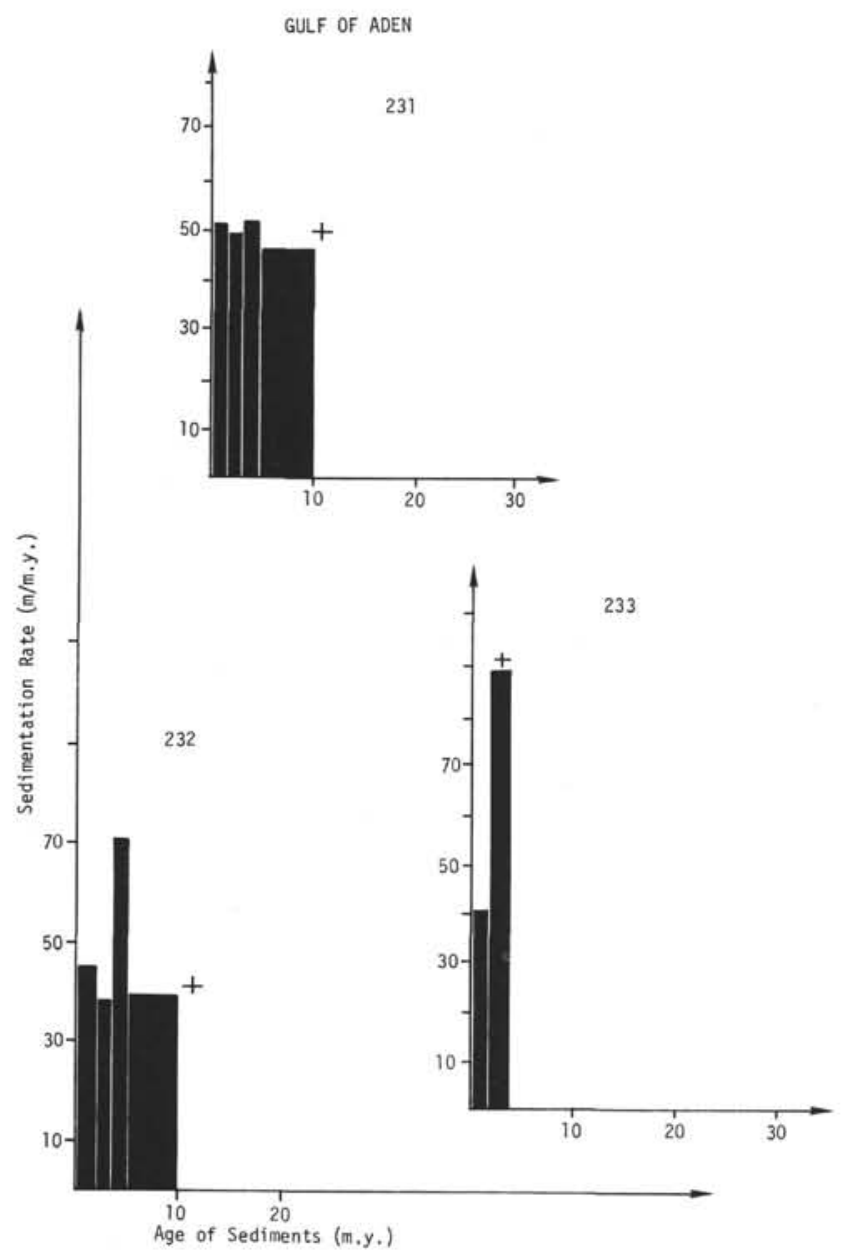

Figure 56. Sedimentation rates in the Gulf of Aden, the Somali Basin, and the central Indian Ocean. Crosses indicate first occurrences of shallow derived fossils. preserved during upper Miocene and Pleistocene than during Pliocene suggesting, along with the preservation pattern of the siliceous fossils, that the reduced oxygen content in the northern Indian Ocean (Wyrtki, 1971) was subject to major fluctuations (Schott et al., 1970; Stackelberg, 1972). This might be correlated to the almost synchronous appearance or disappearance of burrowing/ mottling in the sediments (Figure 7, see Olausson and Olsson, 1969).

The shallow-water-derived fossils indicate a source area between 150 and 400 meters (Stubbings, 1939). They appear earlier in the sediments than expected suggesting a transport along the basin as well as across. Benthic autochthonous fossils (foraminifera, echinoids, as well as remains of fishes) are frequent to abundant throughout the whole sedimentary sequence, which indicates high organic productivity since the middle Miocene.

The sedimentary sequences penetrated on either side of the Alula-Fartak Trench are similar to that at Site 231 in many respects. Therefore only the points which are considerably different from Site 231 will be mentioned.

The basal sediments of Site 232 consist of massive, fossiliferous, quartzose sandstone and nanno oozes at upper Miocene age. The oldest sediments at Site 233, where the drilling was terminated after having penetrated a diabase sill on the eastern flank of the trench, are lower Pliocene in age. This supports the results of Ramsay and Funnell, 1969, who dated sediments from the walls of the trench.

Shallow-water-derived fossils (except plant debris) occur throughout Site 232 but only in upper Pliocene sediments at Site 233, thus indicating that sediments could pass across

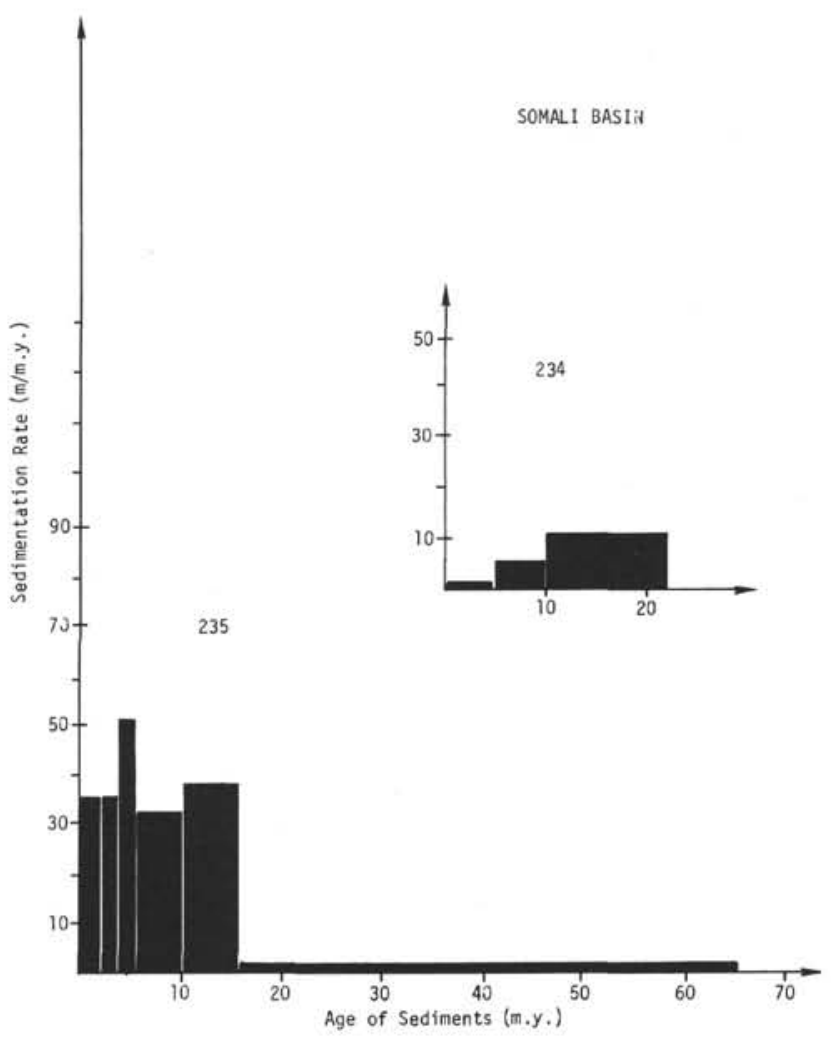

Figure 56. (Continued). 


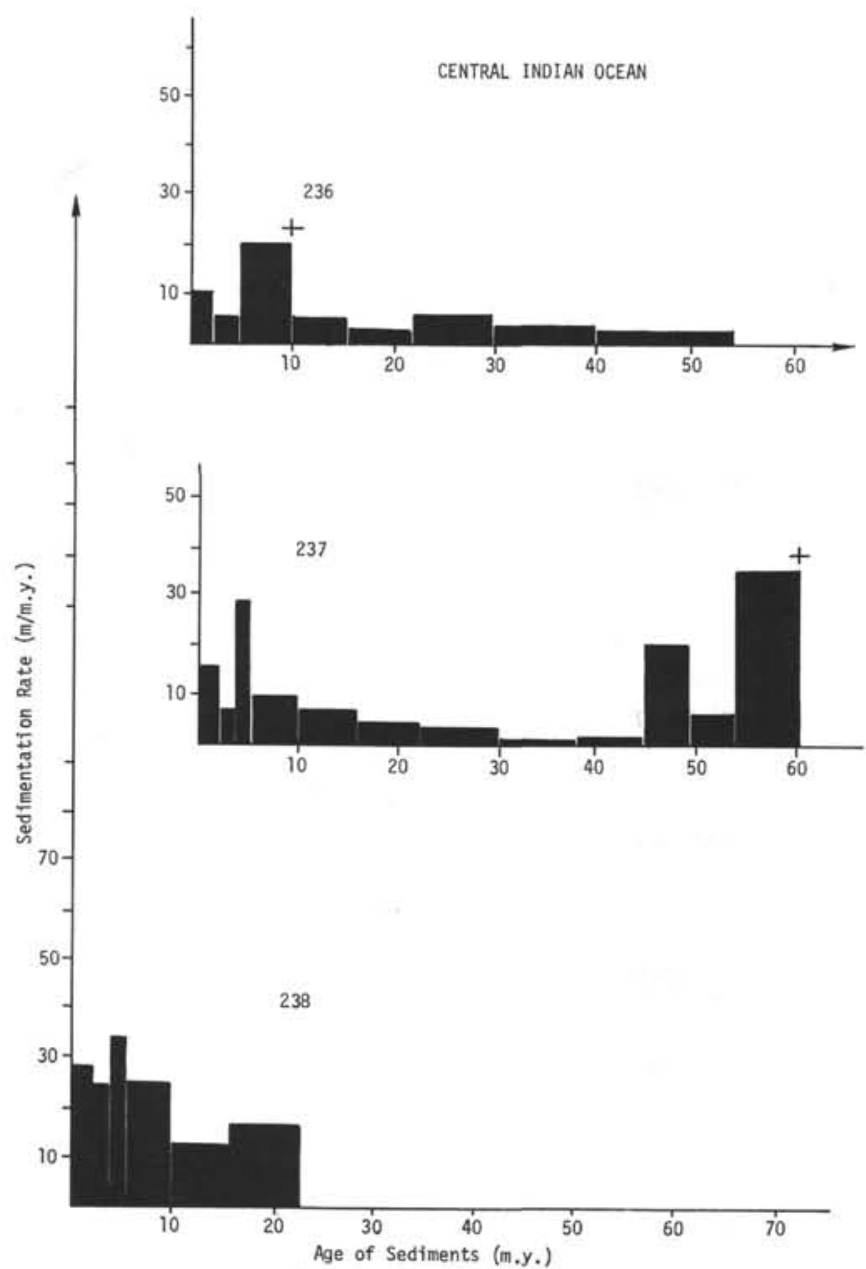

Figure 56. (Continued).

the region now occupied by the Alula-Fartak Trench at that time. Foraminifera, however, do not support this theory. Rock fragments are found in upper Pliocene and Pleistocene samples at Site 232. Volcanic ashes consisting of almost colorless glass similar to those at Site 231 occur in lower Pliocene sediments of all Gulf of Aden sites. However, their number decreases in an easterly direction.

High pore-water salinities and the occurrence of gypsum in the basal sediment at Site 232 suggest the presence of older evaporite-bearing formations below the section cored. Paleoclimatological evidence for arid conditions has been proven for Miocene (Azzaroli, 1968, Azzaroli and Fois, 1964) and Pleistocene times. Knowledge about Pliocene climate is much more scanty. The decrease in abundance of plankton (foraminifera) might be due to climatic fluctuations.

\section{Somali Basin Sites}

Somali Basin sediments were recovered at two sites: Site 234 west of Chain Ridge and Site 235 east of Chain Ridge. Reflection seismic records showed sequences of stratified sediments with an intermediate layer of seismically transparent deposits continuous over great distances (Bunce et al., 1966). The results at both sites revealed considerably distinct geological environments on either side of Chain
Ridge despite their regionality. Important differences between these sites have been tabulated in Table 13, thus this table needs only the addition of the following statements.

Terrigenous detritus from the coarse fractions at both sites differ mainly with respect to quartz/mica ratios (Figure 30), although these minerals are assumed to be mostly wind transported. Sorting and redeposition of these minerals by water cannot be excluded.

It seems remarkable that the oldest sediments at Site 235 are quite similar to those at Site 234 (although these are considerably younger). Although plant debris is almost missing in the lowermost part of 235 and in all of 234 , it is found frequently in the post-middle Miocene sediment at Site 235. It might be interpreted that the sites were located in a continuous basin before this lithologic break at Site 235 or that both sites had similar and then later, different sources of redeposited sediments.

Manganese nodules and crusts are restricted to Site 234 Pliocene and upper Miocene sediments and have also been found in stratigraphically similar levels on the eastern flank of Chain Ridge (Pimm et al., 1972). They indicate a well-oxygenated environment of low sedimentation rate which is characteristic for the elevated Chain Ridge and the western part of the Somali Basin. Although these components are restricted to the uppermost cores of this site, pyrite and zeolites are the characteristic authigenic minerals found below the occurrence of the manganese nodules and crusts. Authigenic pyrite and zeolites are also characteristic at Site 235 .

The higher calcium carbonate content at Site 235, in spite of its greater water depth, indicates that the better preservation of calcareous fossils is related to redeposition of this material from shallow areas by current (either from the direction of Chain Ridge or preferably, due to its greater bulk regionally, from or through Carlsberg Ridge). Siliceous fossils are better preserved at Site 235 than at Site 234 due to higher sedimentation rates (Schrader, 1972a).

Determining the source area of the displaced sediments is a problem. It seems clear from the lithological differences of the sediments on either side of Chain Ridge that the deposits could not have had the same source area, at least not since uppermost middle Miocene. The stratified upper sequence west of Chain Ridge thickens to the east and north but terminates abruptly at Chain Ridge (Bunce et al., 1967) requiring a northern source and the presence of Chain Ridge. The transparent sequence thickens toward the continent to the west and is more clearly stratified here and sloping upward at Chain Ridge which might indicate synsedimentary movements (Bunce et al., 1967).

In conclusion, a northwestern source can be accepted for these sediments. This suggestion can be substantiated by the occurrence of canyons on the Somalia continental margin (Ulrich, 1968) and the occurrence of fossil erosional features at the mouth of the Gulf of Aden and in Somalia (Laughton, 1966). The similarity of the terrigenous components to those of the Gulf of Aden has to be noted. This assumption may also apply to the pre-upper Miocene sediments at Site 235 , but do not fit with the findings in the younger sediments of this site.

Although the sediments east and west of Chain Ridge appear to be rather uniform (Bunce et al., 1967), the 
post-uppermost middle Miocene sediments at Site 235 are different. The different composition of the terrigenous coarse-fraction components associated with the occurrence of plant debris and the presence of bivalve fragments since upper Pliocene suggests a source area other than either Chain or Carlsberg ridges. The parallelity of the occurrence of shallow-water-derived material in upper Pliocene sediment at Site 232 might be an important clue for the solution of this problem. Thus, one has to seek a source area close to the mouth of the Gulf of Aden (Laughton, 1966) which seems to be supported by the occurrence of bivalve fragments. However, the suggestion of Ewing et al., 1963, of a passage of Indus and Ganges cone sediments through Carlsberg Ridge cannot be rejected. A detailed seismic reflection study is needed to solve this problem. The evolution of Owen Fracture Zone and Chain Ridge might bear this missing link (Matthews, 1966).

The type of pelagic basal Upper Cretaceous sediment at Site 235 also suggests that the Somalia Basin must have existed at that time as a wide ocean basin. This does not support the hypothesis of McElhinny (1970) that India and Madagascar maintained their proximity until Late Cretaceous.

\section{Central Indian Ocean Sites}

The three DSDP sites in the central Indian Ocean offer insight into problems of sedimentation in a tropical ocean. Two of these sites are situated west of Carlsberg-Central Indian Ridge (Sites 236 and 237) and one east of the Central Indian Ridge south of Chagos-Laccadive Ridge. They lie therefore on pieces of ocean floor belonging to different plates. Sites 236 and 238 are situated above magnetic anomalies in part recognizable as to age and strike (Site 236) as shown by Fisher et al., 1971. The basement below 237 on the saddle between Saya de Malha Bank and the Seychelles is unknown, but seems not to be normal oceanic basement because it lacks clear magnetic anomalies. For further structural details of the area covered by these three sites, see Fisher et al. (1967, 1968, and 1971).

Site 236 was supposed to penetrate sediment down to oceanic basement belonging to magnetic anomaly 27 (?) (early Paleocene). The oldest recovered sediment was upper Paleocene. The section penetrated consisted of nanno oozes/chalk and clays (in lower Miocene and upper Oligocene).

These clays do suggest that the site was situated at that time below the calcium carbonate compensation depth. There is a surprising time correlation of the preservation of calcareous fossils to the shifts of spreading rates and directions. Oscillation of the sea floor due to these shifts might also control the position of this site relative to the calcium carbonate compensation depth.

A certain portion of the terrigenous clastic components in the coarse fraction of the sediments seems to have been transported by wind, others come together with shallowwater fossils presumably from Seychelles Bank. Volcanic ashes were found mainly in Oligocene and Miocene sediments.

The occurrence of frequent, well-defined, coarse-grained horizons with well-preserved calcareous components in a fine-grained matrix of poorly preserved calcareous fossils indicates that a high portion of these sediments is redeposited. The source of these sediments must have been, during pre-upper Miocene times, an area of purely pelagic sediments, and during upper Miocene and Pliocene, Seychelles Bank or a similar area, which is shallow enough to produce the registered fossils and which consists of continental crust. The appearance of shallow-water-derived components during upper Miocene is in striking time coincidence with similar findings at Site 235 and in the Gulf of Aden (Figure 59).

High proportions of well-preserved siliceous fossils (Figure 41) suggest that this site was situated, at least since Eocene, under or very near the high production belt of the equatorial divergences (Riedel, 1971). Major fluctuations in the presence of the siliceous fossils might be either due to differences of the preservation or to relative movements of this belt.

Site 237 is situated today in only 1640 meters of water between the Seychelles and Saya de Malha. The layered sediments (Bunce et al., 1966) were penetrated down to lower Paleocene and are pelagic throughout (despite a previously expected thick coralline and glauconite-rich sequence).

Shallow-water-derived fossils were found only in Paleocene and upper Oligocene sediments. However, these

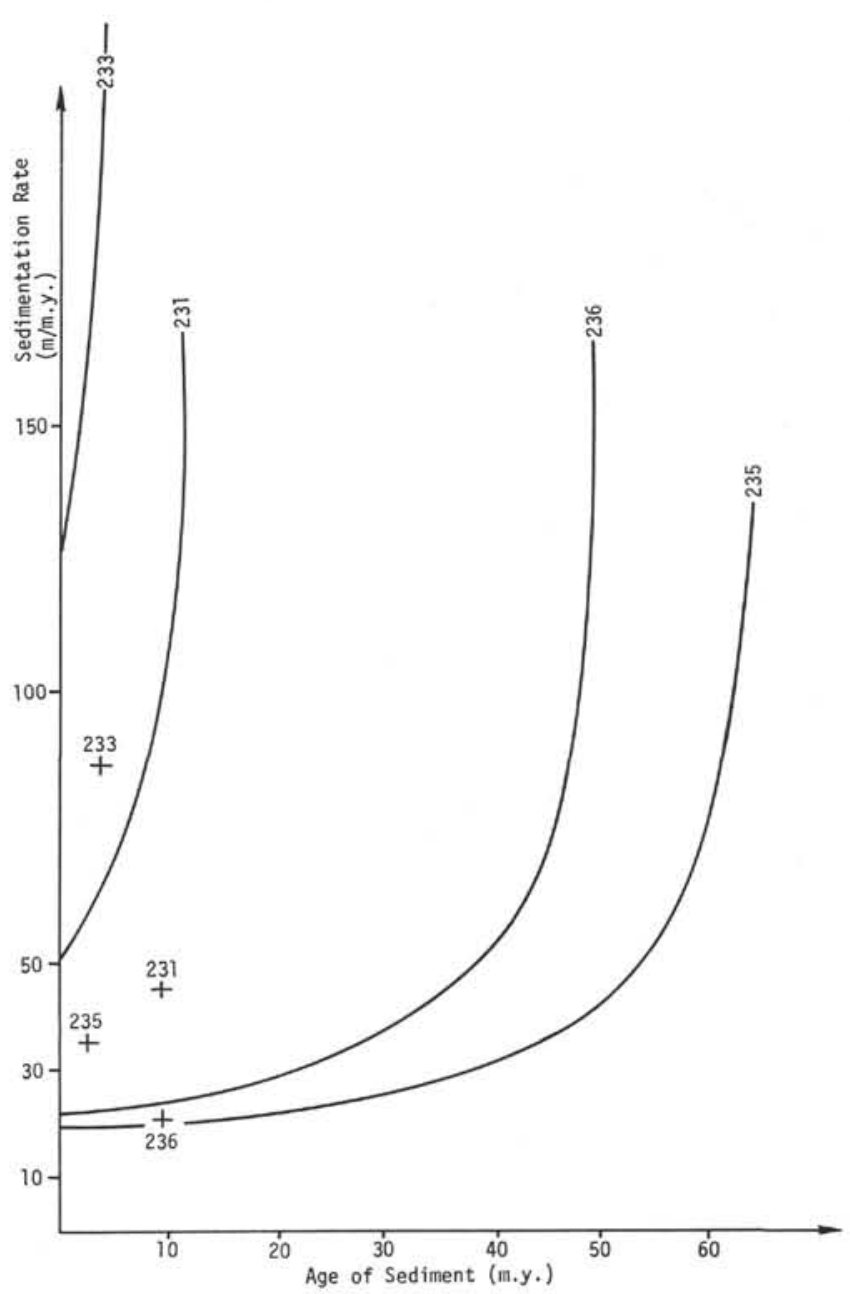

Figure 57a. Correlation of the first occurrence of shallow water derived components and of sedimentation rates of "mother" sediments (curves are segments of Figure $55 B)$. 


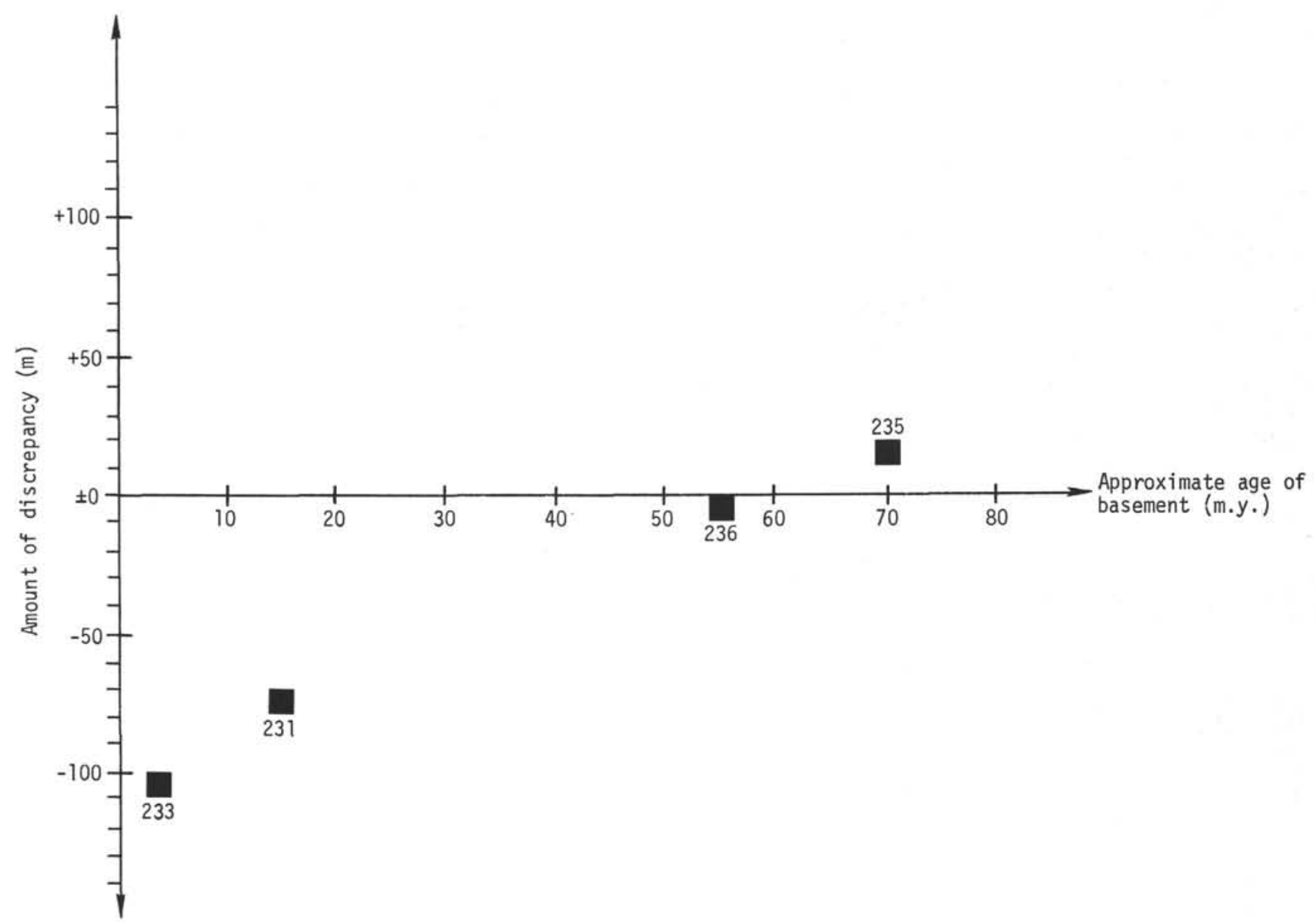

Figure 57b. Discrepancy of expected minimum sedimentation rates and actually found values versus age of basement of sites.

fossils (algal crusts, large benthic foraminifera) do not allow inferences concerning a specific shallow site to be made. Since they only occur in thin horizons intercalated in a recrystallized matrix of presumably nanno chalk, they do not offer any indication of the water depth into which these shallow-water fossils were redeposited, although it could not have been very shallow (at least several hundred meters; compare Vincent et al., this volume.

The preservation of planktonic foraminifera offers several possibilities for interpreting paleodepths. They indicate that the water depth has not changed considerably since lower/upper Oligocene (rather coarse-grained sediments: winnowed?). Their poor preservation in older (not winnowed?) sediments might be either due to very shallow water depths (would this be consistent with the finer grain sizes of these sediments?) or to water depths of about 4000 meters (Figure 51), still well above the calcium carbonate compensation depth. Critical times for these possible movements seem to be middle Eocene to lower Oligocene.

Siliceous fossils do not occur frequently before Eocene time. Fluctuations in their abundance are very similar to Site 236 and indicate either a similar pattern of $\mathrm{SiO}_{2}$ preservation as found at Site 236 or rather simultaneous relative movements of both sites to the high production belt under the equatorial divergences (Riedel, 1971). The position of Sites 236 and 237 in the equatorial area is not consistent with India's supposed south-north movement in the Late Cretaceous - early Tertiary (McElhinny, 1970), since the basal sediments of both sites also require an open-oceanic environment.

The upper Oligocene to Recent sediments of Site 238 on the margin of the Central Indian Ridge, within or very close to the Argo Fracture Zone, are entirely highly pelagic.

Since the site never was deeper than the calcium carbonate compensation depth, all calcareous components are well preserved. The consistency of this site through time with age/depth constancy is proven by the increasingly better preservation of calcareous particles with increasing age of sediments. The basement today is much higher than expected from subsidence curves, possibly due to the proximity to, or perhaps occurrence within the Argo Fracture Zone (see Engel and Fisher, 1969, figure 1).

The increasing abundance of siliceous components demonstrates (if this is not interpreted as a phenomenon of preservation) the relative movement of the crust below this site closer to the equatorial high production belt. Siliceous fossils occur frequently since uppermost lower Miocene.

The basal sediments are metalliferous and contain components of volcanic origin and authigenic minerals, a result of posteruptive volcanic activity along the transform fault while this site was still close to the rifting area. The volcanic input decreases in younger sediment, as the crust at this site moves away from the active rift.

It seems important to note that a high proportion of the sediments at all sites are displaced (Parker, 1971) in close agreement with the structural movement of the oceanic 
TABLE 13

Differences Between Site 234 (West of Chain Ridge) and Site 235 (East of Chain Ridge)

\begin{tabular}{|c|c|c|}
\hline & Site 234 & Site 235 \\
\hline Water depth (m) & 4738 & 5146 \\
\hline $\begin{array}{l}\text { Basin } \\
\text { boundaries }\end{array}$ & $\begin{array}{l}\text { Continental margin } \\
\text { with canyons } \\
\text { (Ulrich, 1968) west } \\
\text { and north, Chain } \\
\text { Ridge southeast, } \\
\text { open to southwest }\end{array}$ & $\begin{array}{l}\text { Chain Ridge northwest, } \\
\text { Carlsberg Ridge north- } \\
\text { east, open to the south }\end{array}$ \\
\hline Basement & $\begin{array}{l}\text { Unknown, not } \\
\text { reached, oldest dated } \\
\text { sediments } \\
\text { Oligocene }\end{array}$ & $\begin{array}{l}\text { Basaltic, Upper } \\
\text { Cretaceous }\end{array}$ \\
\hline Sediments & $\begin{array}{l}\text { Clays and nanno } \\
\text { clays, overlain by } \\
\text { nanno ooze. Very } \\
\text { fine-grained in } \\
\text { the whole basin } \\
\text { (Muller, 1967) }\end{array}$ & $\begin{array}{l}\text { Nanno oozes and } \\
\text { nanno clays }\end{array}$ \\
\hline $\begin{array}{l}\text { Sedimentation } \\
\text { rates }(\mathrm{m} / \mathrm{m} . \mathrm{y} .)\end{array}$ & $\begin{array}{l}\text { Decreasing from } \\
>10 \mathrm{~m} \text { during } \\
\text { lower and middle } \\
\text { Miocene to }<2 \mathrm{~m} \\
\text { during Plio/ } \\
\text { Pleistocene }\end{array}$ & $\begin{array}{l}<2 \mathrm{~m} \text { Upper } \\
\text { Cretaceous to } \\
\text { lower Miocene } \\
\text { (hiatus?) } \\
30-50 \mathrm{~m} \text { since } \\
\text { middle Miocene }\end{array}$ \\
\hline $\begin{array}{l}\text { Coarse fractions } \\
\text { Terrigenous } \\
\text { Components }\end{array}$ & $\begin{array}{l}\text { Quartz >Mica } \\
\text { (Upper Oligo- } \\
\text { cene to Recent) }\end{array}$ & $\begin{array}{l}\text { Quartz > Mica } \\
\text { (Upper Cretaceous } \\
\text { to Miocene) } \\
\text { Quartz < Mica } \\
\text { (Miocene-Recent) }\end{array}$ \\
\hline $\begin{array}{l}\text { Calcareous } \\
\text { plankton }\end{array}$ & Poorly preserved & $\begin{array}{l}\text { Moderately to well } \\
\text { preserved }\end{array}$ \\
\hline $\begin{array}{l}\text { Siliceous } \\
\text { fossils }\end{array}$ & $\begin{array}{l}\text { Very poorly } \\
\text { preserved }\end{array}$ & $\begin{array}{l}\text { Moderately } \\
\text { preserved }\end{array}$ \\
\hline Fish remains & Very frequent & Common to seldom \\
\hline $\begin{array}{l}\text { Shallow-water- } \\
\text { derived fossils }\end{array}$ & None & $\begin{array}{l}\text { Fragments of bivalves } \\
\text { in upper Pliocene and } \\
\text { Pleistocene sediments, } \\
\text { frequent plant debris } \\
\text { since middle Miocene }\end{array}$ \\
\hline
\end{tabular}

crust and ruled by an equilibrium between subsidence of crust and total sedimentation rates (Figure 55). Shallowwater-derived components have been found surprisingly contemporaneous in a number of sites in late Tertiary sediments (Figure 57). The fragmentation of planktonic foraminifera appears to be a refined tool for the determination of paleodepths (Figure 47).

\section{ACKNOWLEDGMENTS}

My participation in Leg 24 of the Deep Sea Drilling Project and the subsequent laboratory work were supported by the National Science Foundation and the "Deutsche Forschungsgemeinschaft."

The results of this study draw extensively also on data produced by the Leg 24 shipboard scientific party (Chief scientists: E.T. Bunce from Woods Hole Oceanographic Institution, Woods Hole, Mass. and R. L. Fisher, Scripps Institution of Oceanography, La Jolla, California). The sample preparation was mainly done in the laboratories of Geological Institutes of the Universities of Bergen, Norway and Aarhus, Denmark in collaboration with very helpful assistants of these institutions. Aarhus University also liberated me from all other duties during Leg 24 which is gratefully acknowledged.

F. Werner (Geological Institute, University of Kiel, Germany) helped in impregnating the sediment samples for thin sections. G. Pautot (Centre Oœéanologique de Bretagne, Brest, France) allowed me to use his Indian Ocean map (see Figure 58). I obtained the CHAIN samples through E. T. Bunce from Woods Hole Oceanographic Institution, the ANTIPODE samples through R. L. Fisher and P. B. Helms of Scripps Institution of Oceanography. Thin sections of a number of consolidated sedimentary rocks made onboard by L. Dmitriev were used for certain micrographs (as indicated in the figure and plate descriptions).

The invaluable assistance from all members of the Deep Sea Drilling shipboard party of Leg 24 is specially mentioned and acknowledged.

\section{REFERENCES}

Azzaroli, A., 1968. On the evolution of the Gulf of Aden: Internatl. Geol. Congr., 23rd, v. 1 p. 125-134.

Azzaroli, A. and Fois, V., 1964. Geological outlines of the northern end of the Horn of Africa: Internatl. Geol. Congr. 22nd Proc., v. 4, p. 293-314.

Belyaeva, N. V., 1970. Distribution of planktonic foraminiferal tests in sediments from the rift zone of the Indian Ocean: Okeanologia, v. 10 p. 681-685.

Berger, W. H., 1968. Planktonic foraminifera: selective solution and paleoclimatic interpretation: Deep-Sea Res., v. 15, p. 31-43. 1970. Planktonic foraminifera: Selective solution and the lysocline: Marine Geol., v. 8, p. 111-138. 1971. Sedimentation of planktonic foraminifera: Marine Geol., v. 11, p. 325-358. , 1972. Deep sea carbonates: dissolution facies and age depth constancy: Nature, v. 236, p. 392-395. , 1973. Cenozoic sedimentation in the Eastern Tropical Pacific: Geol. Soc. Am. Bull., v. 84, p. 1941-1954.

Berger, W. H. and von Rad U. 1972. Cretaceous and Cenozoic sediments from the Atlantic Ocean In Hayes, D. E., Pimm, A. C. et al., Initial Reports of the Deep Sea Drilling Project, v. 14: Washington (U.S. Government Printing Office), p. 787-954.

Berggren, W. A. 1972. A Cenozoic time-scale - some implications for regional geology and paleobiogeography: Lethaia, v. 5, p. 195-215.

Beydoun, Z. R., 1970. Southern Arabia and northern Somalia: comparative geology: Phil. Trans. Roy. Soc. London, Ser. A, v. 267, p. 267-292.

Bunce, E. T., Bowin, C. O., and Chase, R. L., 1966. Preliminary results of the 1964 cruise of R.V. Chain to the Indian Ocean: Phil. Trans. Roy. Soc. London Ser. A, v. 259 , p. $218-226$.

Bunce, E. T., Langseth, M. G., Chase, R. L., and Ewing, M., 1967. Structure of the western Somali Basin: J. Geophys. Res., v. 72, p. 2547-2555.

Casey, R. E., 1971. Radiolarians as indicators of past and present water-masses: In Funnell, B. M. and Riedel, W. R. (Eds.), The micropalaeontology of oceans: Cambridge (Cambridge University Press), p. 331-341.

Einsele, G. and Werner, F., 1968. Zusammensetzung, Gefüge und mechanische Eigenschaften rezenter Sedimente vom Nildelta, Roten Meer und Golf von Aden: "Meteor" Forsch.-Ergebn., C., v. 1, p. 21-42. 


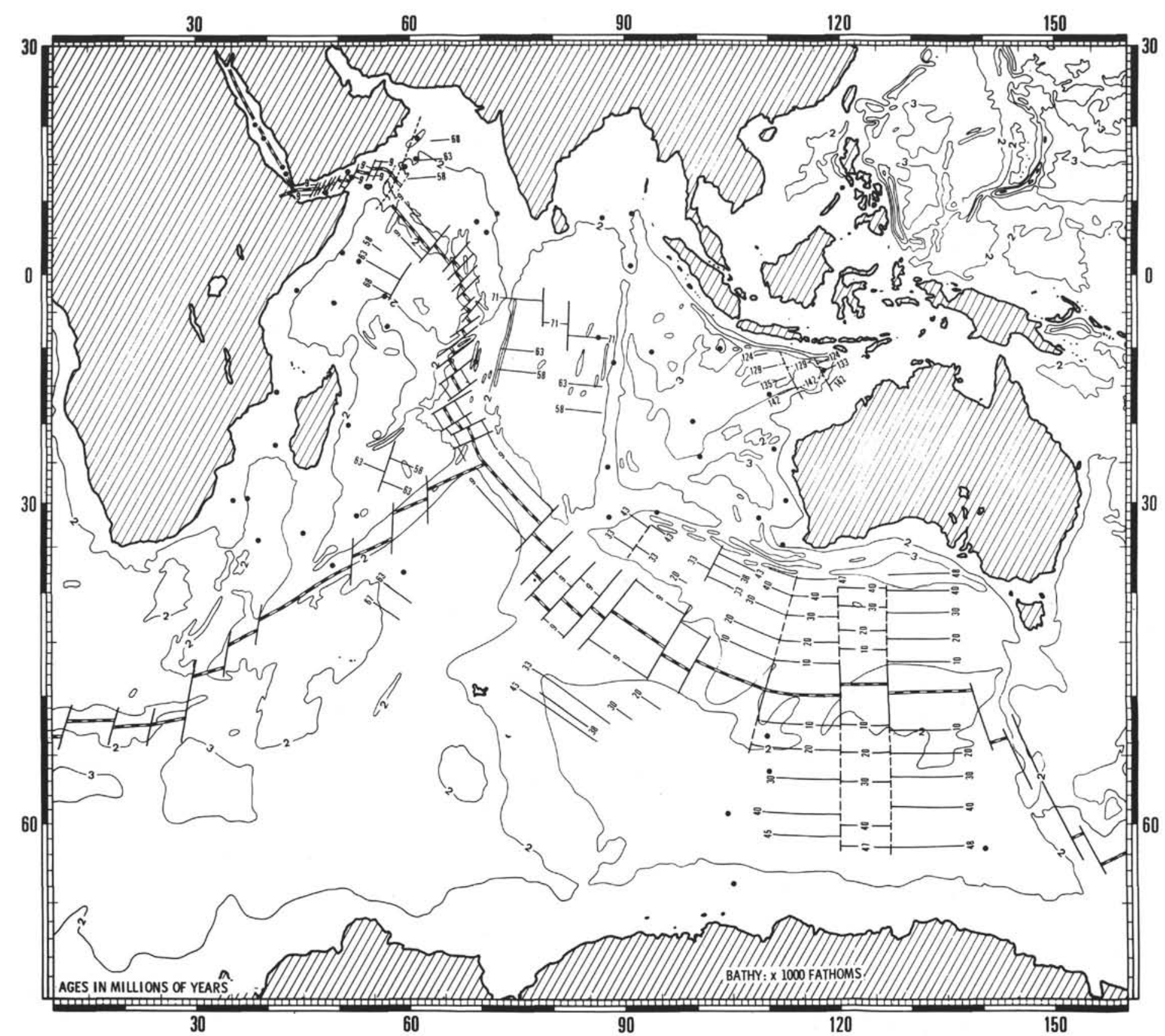

Figure 58. Situation of all Indian Ocean Deep-Sea Drilling Project drill sites (G. Pautot, personal communication). 

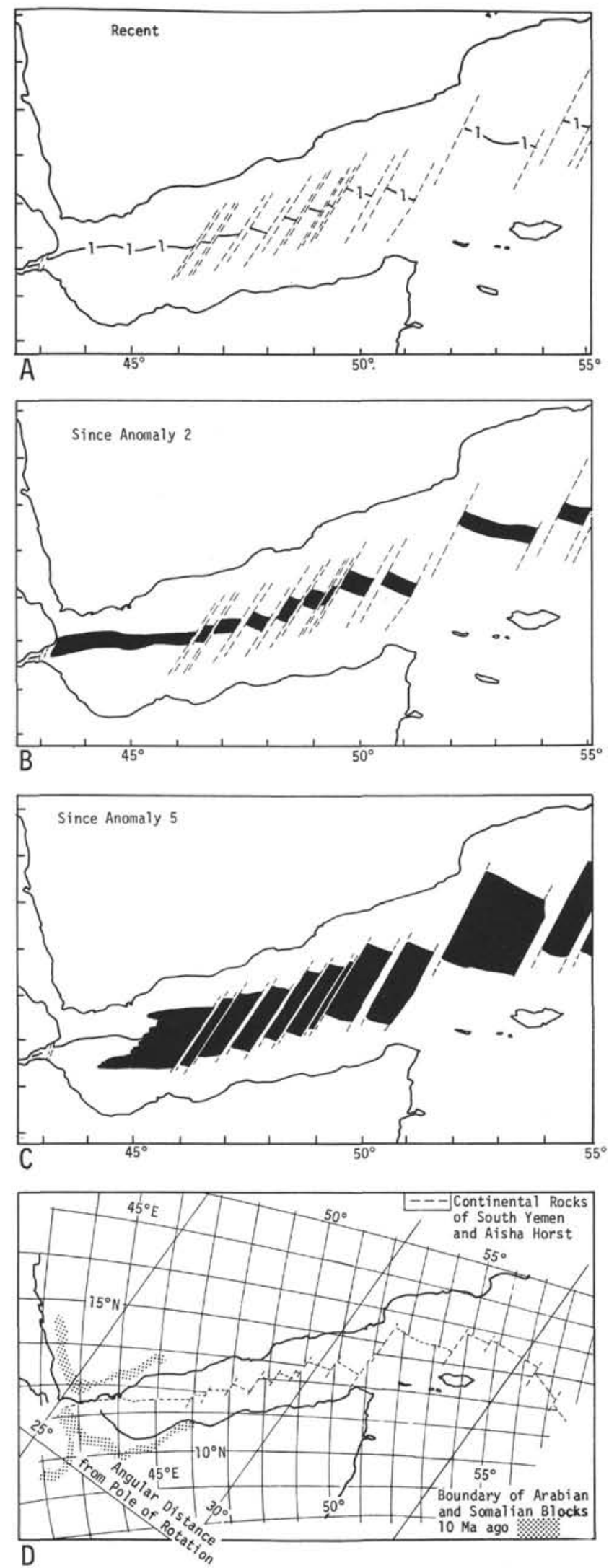

Figure 59. Development of the Gulf of Aden since Middle Miocene 'after Laughton et al., 1970)(A) Recent stage;

(B) oceanic crust formed since anomaly 2 (in black);

(C) oceanic crust formed since anomaly 5 (in black);

(D) paleogragraphic situation about 10 Mio. yrs. age.
Engel, G. G. and Fisher, R. L., 1969. Lherzolite, Anorthosite, Gabbro and Basalt Dredged from the Mid-Indian Ocean Ridge: Science, v. 166, p. 1136-1141.

Ewing, M., Eittreim, S., Truchan, M., and Ewing, J. I., 1963. Sediment distribution in the Indian Ocean: Deep-Sea Res., v. 16, p. 231-248.

Fisher, R. L. (Ed.), 1964. Preliminary results of Scripps Institution of Oceanography investigations in the Indian Ocean during Expedition Monsoon and Lusiad 1960-1963: Scripps Inst. Oceanogr., Ref. 64-19, p. 1-237.

Fisher, R. L., Bunce, E. T., Cernock, P. J., Clegg, D. C., Cronan, D. S., Damiani, V. V., Dimitriev, L., Kinsman, D. J. J., Roth, P. H., Thiede, J., and Vincent, E. S., 1972. Deep Sea Drilling Project in dodo land: Geotimes, v. 17, p. 17-21.

Fisher, R. L., Engel, G. G., and Hilde, T.W.C., 1968. Basalts dredged from the Amirante Ridge, western Indian Ocean: Deep-Sea Res., v. 15, p. 521-534.

Fisher, R. L., Johnson, G. L., and Heezen, B. C., 1967. Mascarene Plateau, western Indian Ocean: Geol. Soc. Am. Bull., v. 78, p. 1247-1266.

Fisher, R. L., Sclater, J. G., and McKenzie, D. P., 1971. Evolution of the Central Indian Ridge, western Indian Ocean: Geol. Soc. Am. Bull., v. 82, p. 553-562.

Füchtbauer, H. and Müller, G., 1970. Sedimente Sedimentgesteine: Stuttgart.

Goldberg, E. D. and Griffin, J. J., 1970. The sediments of the northern Indian Ocean: Deep-Sea Res., v. 17, p. 513-537.

Grimsdale, T. F. and von Morkhoven, F.P.C. M., 1955. The ratio between pelagic and benthonic foraminifera as a means of estimating depth of deposition of sedimentary rocks: World Petrol. Congr. 44th Proc., v. 4, p. 473-491.

Herman, Y., 1971. Vertical and horizontal distribution of pteropods in Quaternary sequences. In Funnell, B. M. and Riedel, W. R. (Eds.), The micropalaeontology of oceans: Cambridge (Cambridge University Press), p. 463-486.

Kozlova, O. G., 1971. The main features of diatom and silico-flagellate distribution in the Indian Ocean. In Funnell, B. M. and Riedel, W. R. (Eds.), The micropalaeontology of oceans: Cambridge (Cambridge University Press), p. 271-275.

Kudrass, H. R., 1973. Sedimentation am Kontinentalrand vor Portugal und Marokko im Spätpleistozän und Holozän: "Meteor" Forsch.-Ergebn., C, v. 13 p. 1-63.

Laughton, A. S., 1966. The Gulf of Aden: Phil. Trans. Roy. Soc. London, Ser. A, v. 259, p. 150-171.

Laughton, A. S., Whitmarsh, R. B., and Jones, M. T., 1970. The evolution of the Gulf of Aden: Phil. Trans. Roy. Soc. London, Ser. A, v. 267, p. 227-266.

Lisitzin, A. P., 1971. Distribution of siliceous microfossils in suspension and bottom sediments. In Funnell, B. M. and Riedel, W. R. (Eds.), The micropalaeontology of oceans: Cambridge (Cambridge University Press), p. 173-195.

Matthews, D. H., 1966. The Owen Fracture Zone and the northern end of the Carlsberg Ridge: Phil. Trans. Roy. Soc. London, Ser. A, v. 259, p. 177-186.

McElhinny, M. W., 1970. Formation of the Indian Ocean: Nature, v. 228, p. 977-979.

McKenzie, D. and Sclater, J. G., 1971. The evolution of the Indian Ocean since the Late Cretaceous: Geophys. J. Roy. Astron. Soc., v. 25, p. 437-528.

Müller, C. 1967. The $\mathrm{HCl}$ soluble iron, manganese, and copper contents of Recent Indian Ocean sediments off 
the Eastern Coast of Somalia: Mineral Depos., v. 2, p. 54-61.

Olausson, E. and Olsson, J. U., 1969. Varve stratigraphy in a core from the Gulf of Aden: Palaeogeogr., Palaeoclimat., Palaeoecol., v. 6, p. 87-193.

Parker, F. L., 1971. Distribution of planktonic foraminifera in Recent deep-sea sediments. In Funnell, B. M. and Riedel, W. R. (Eds.), The micropalaeontology of oceans: Cambridge (Cambridge University Press), p. 289-307.

Petrushevskaya, M. G., 1971. Radiolaria in the plankton and Recent sediments from the Indian Ocean and Antarctic: In Funnel, B. M. and Riedel, W. R. (Eds.), The micropalaeontology of oceans: Cambridge (Cambridge University Press), p. 319-329.

Pimm, A. C., Burroughs, R. H., and Bunce, E. T., 1972. Oligocene sediments near Chain Ridge, northwest Indian Ocean: structural implications: Marine Geol., v. 13, p. M14-M18.

Puri, H. S., 1971. Distribution of ostracods in the oceans. In Funnell, B. M. and Riedel, W. R. (Eds.), The micropalaeontology of oceans: Cambridge (Cambridge University Press), p. 163-169.

Ramsay, T. S. and Funnell, B. M., 1969. Upper Tertiary microfossils from the Alula Fartak Trench, Gulf of Aden: Deep-Sea Res., v. 16, p. 25-43.

Riedel, W. R., 1971. The occurrence of pre-Quaternary radiolaria in deep-sea sediments. In Funnell, B. M. and Riedel, W. R. (Eds.), The palaeontology of oceans: Cambridge (Cambridge University Press), p. 567-594.

Sarnthein, M., 1971. Oberflächensedimente im Persischen Golf und Golf von Oman II. Quantitative Komponentenanalyse der Grobfraktion: "Meteor" Forsch.-Ergebn., C, v. 5, p. $1-113$.

Schott, W., Stackelberg, U., von Eckhardt, F. J., Mattiat, B., Peters, J., and Zobel, B., 1970. Geologische Untersuchungen an Sedimenten des indischpakistanischen Kontinentalrandes (Arabisches Meer): Geol. Rdsch., v. 60 , p. $264-275$.

Schrader, H. J., 1971a. Kieselsäureskelette in Sedimenten des ibero-marokkanischen Kontinentalrandes und angrenzender Tiefsee-Ebenen: "Meteor" Forsch:Ergebn., C., v. 8, p. 10-36.

1971 b. Ursache and Ergebnis der Auflösung von Kieselskeletten in den oberen Sedimentbereichen am Beispiel zweier Kernprofile vor Marokko und Portugal: Plankt. Conf. Proc. 2nd, v. 2, p. 1149-1155.
Sclater, J. G. and Detrick, R., 1973. Elevation of mid-ocean ridges and the basement age of JOIDES Deep Sea Drilling sites: Geol. Soc. Am. Bull., v. 84, p. 1547-1554.

Sclater, J. G., Anderson, R. N., and Bell, M. L. 1971. Elevation of ridges and the evolution of central eastern Pacific: J. Geophys. Res., v. 76, p. 7888-7915.

Shor, G. C. and Pollard, D. D., 1963. Seismic investigations of Seychelles and Saya de Malha banks, northwest Indian Ocean: Science, v. 142, p. 48-49.

Simpson, E., Schlich, R., Leclaire, L., Moore, C., Girdley, W. A., White, S. M., Vallier, T., Müller, C., Zobel, B., Sigal, J., Gieskes, J., and Marshall, B. V., 1972. Leg 25, DSDP western Indian Ocean: Geotimes, v. 17, p. 21-24.

Stubbings, H. G., 1939. The marine deposits of the Arabian Sea: Sci. Rept. John Murray Expedit., 1933-1934, v. 3, p. 32-158.

Thiede, J., 1973a. Planktonic foraminifera in hemipelagic sediments: Shell preservation off Portugal and Morocco: Geol. Soc. Am. Bull., v. 84, p. 2749-2754.

1973b. Sedimentation rates of planktonic and benthic foraminifera in sediments from the Atlantic continental margin of Portugal and Morocco: "Meteor" Forsch.-Ergebn., C, v. 16, p. 1-18.

Ulrich, J., 1968. Die Echolotungen des Forschungsschiffes "Meteor" im Arabischen Meer während der Internationalen Indischen Ozean Expedition: "Meteor" Forsch.Ergebn., C, v. 1, p. 1-13.

Van Andel, T. H. and Bukry, D., 1973. Basement ages and basement depths in the Eastern Equatorial Pacific from Deep Sea Drilling Project Legs 5, 8, 9 and 16: Geol. Soc. Am. Bull., v. 84, p. 2361-2370.

von Stackelberg, U., 1972. Faziesverteilung in Sedimenten des indisch-pakistanischen Kontinentalrandes (Arabisches Meer): “Meteor"' Forsch-Ergebn., C, v. 9, p. $1-73$.

Whitmarsh, R. B., Weser, O., Ali, S., Boudreaux, J. E., Fleisher, R. L., Jipa, D., Kidd, R. B., Mallik, T. K., Matter, H., Nigrini, C., Siddiquie, H. N., and Stoffers, P., 1972. Deep-Sea Drilling Project in the Arabian Sea: Geotimes, v. 17 , p. 22-24.

Wyrtki, K. (Ed.), 1971. Oceanographic atlas of the international Indian Ocean expedition: Washington (U.S. Government Printing Office). 


\section{PLATE 1}

Sediments at Site 231 off Somalia (smear slides).

Figure 1

Sample 1-1, $115 \mathrm{~cm}$. Quaternary sediment consists mainly of debris of biogenic skeletons (Radiolaria, diatoms, foraminifera) and terrigenous mineral grains. The matrix is dominated by coccoliths.

Figures 2, 3 Sample $3-2,80 \mathrm{~cm}$. Quaternary nannofossil ooze with debris and shells of foraminifera (mainly planktonic).

Figure 4

Sample 3-4, $120 \mathrm{~cm}$. Quaternary nannofossil ooze with debris and shells of foraminifera. Remark big benthic foraminifera.

Figure 5 Sample 21-2, $108 \mathrm{~cm}$. Lower Miocene, many horizons at Site 231 contain big terrigenous mineral grains, partly well rounded. Remark large dolomite rhomb. Matrix consists mainly of coccoliths.

Figure 6 Sample 35-5, $100 \mathrm{~cm}$. Upper Miocene nannofossil ooze with high proportion of terrigenous components. Remark typical discoasters. 
PLATE 1

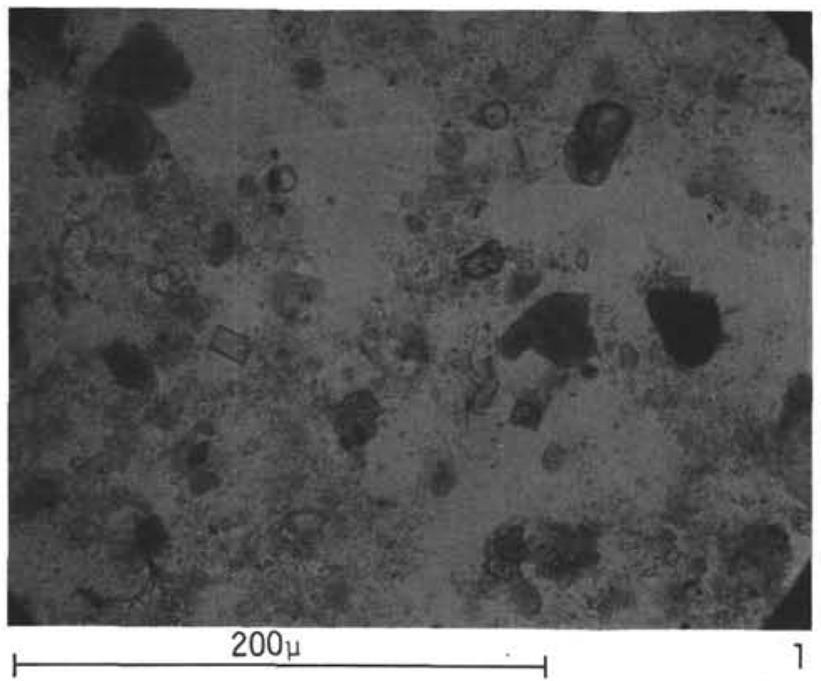

$231-1-7-115$

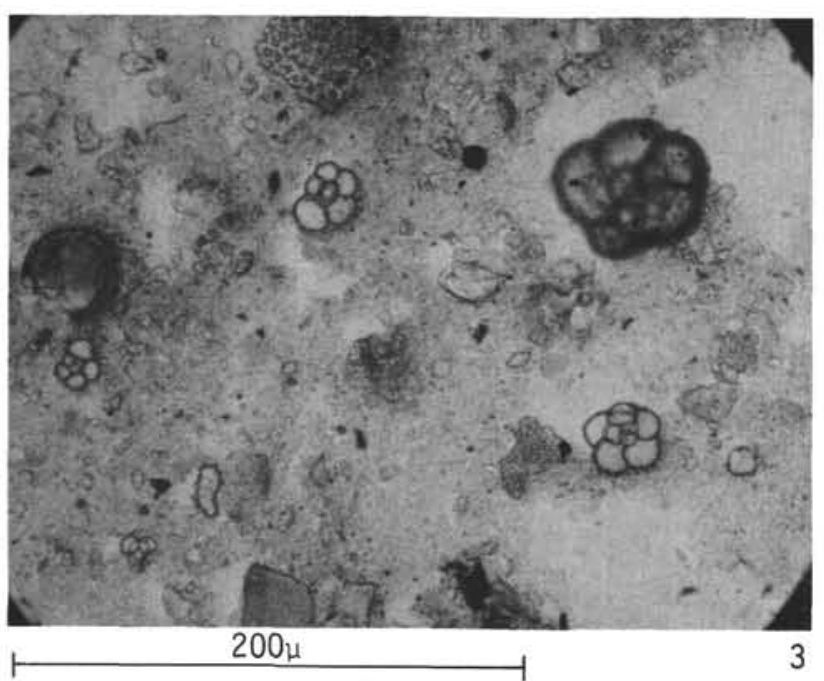

$231-3-2-80$

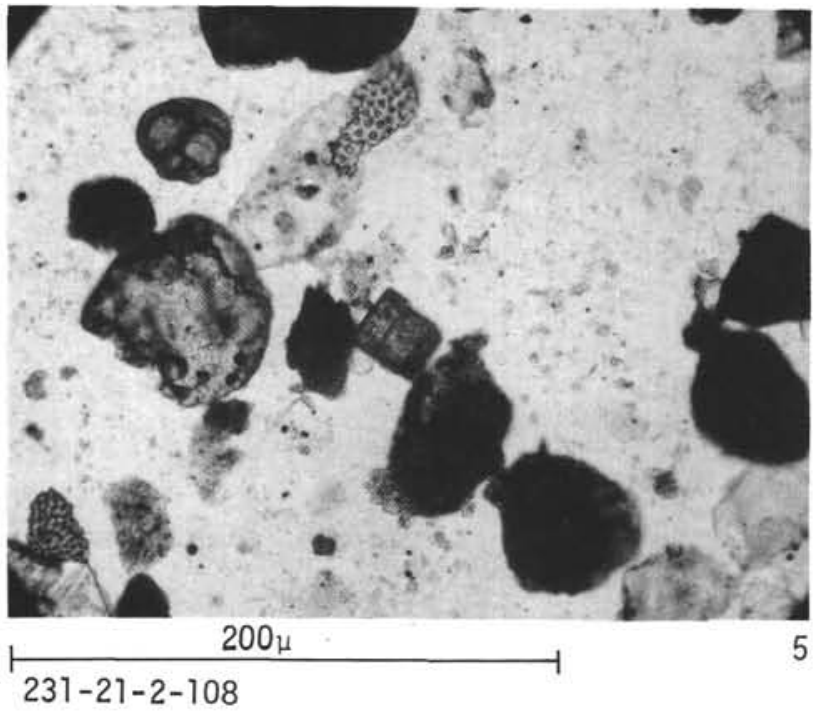

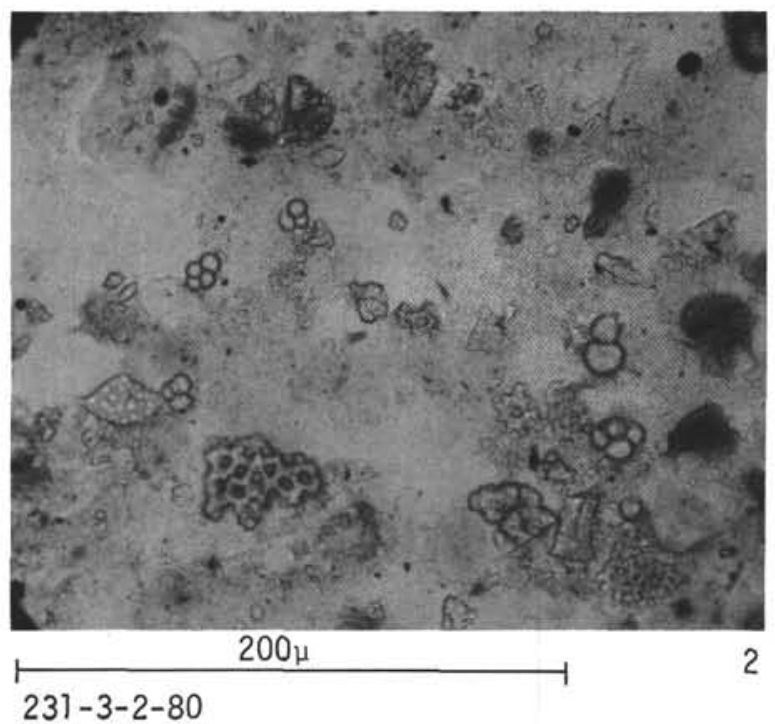
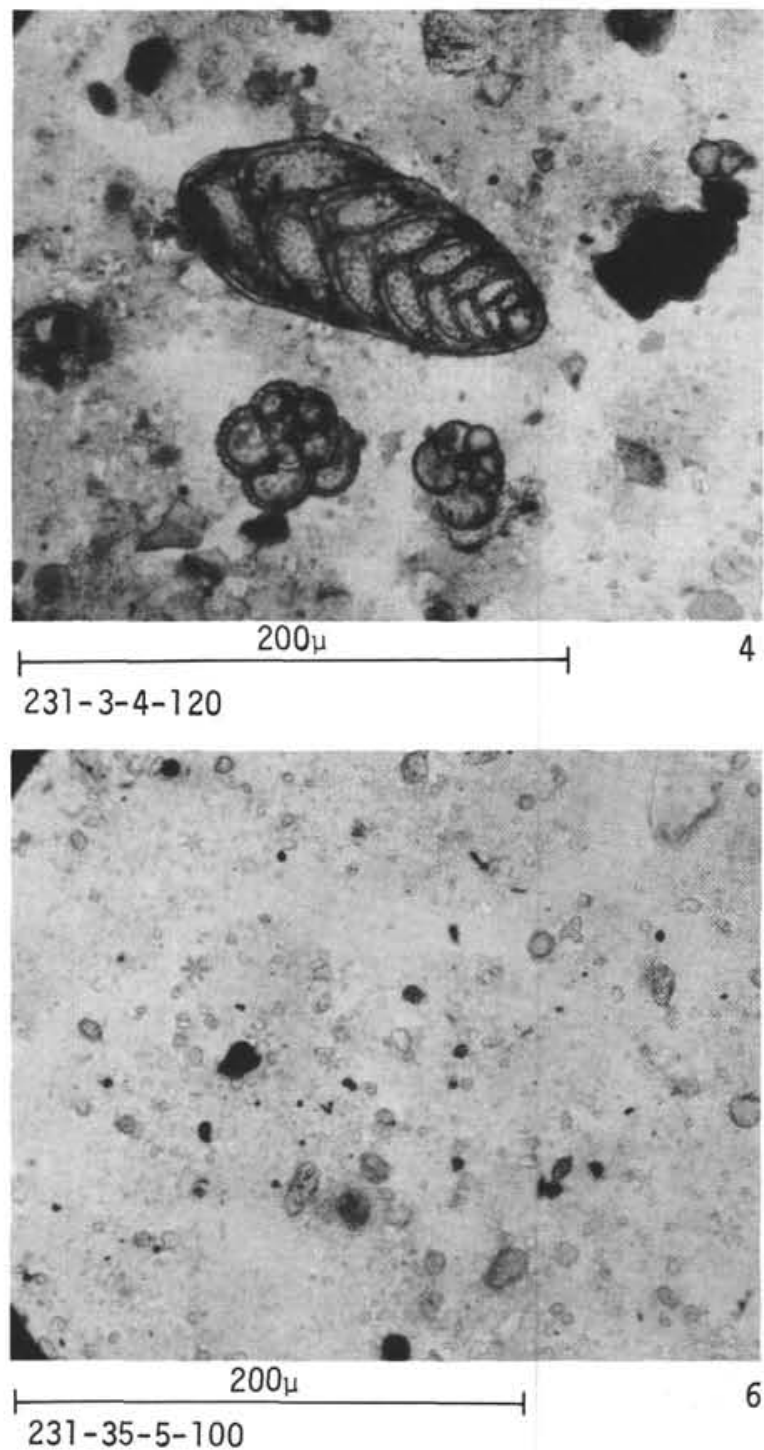


\section{PLATE 2}

Sediments at Site 231. Biogenic activity characterizes in some horizons the otherwise apparently very homogeneous sediments of the Gulf of Aden. Four types of burrows have been found.

Figure 1

Figure 3
Sample 44-1, 77-100 cm; a plane-like horizontal type, rather undifferentiated, the planes of burrowing are $0.5-1.0 \mathrm{~cm}$ thick; tube-like burrows, $0.5-1.0 \mathrm{~cm}$ in diameter, with homogeneous infilling, either of the same sediment as surrounding (many times only to be recognized because of pyrite coatings) or of sediment, which is different from the surrounding sediment either due to different texture or different color.

Sample 53-2,77-100 cm; tube-like burrows $0.5-1.0 \mathrm{~cm}$ in diameter, with typical internal structures.

Sample 53-6, 77-99 cm; small tube-like burrows $1-2 \mathrm{~mm}$ in diameter, occurring in discrete horizons. Burrowing can be of such an intensity that only cloud-like structures are preserved.

Sample 58-6, 101-124 cm. 
Plate 2
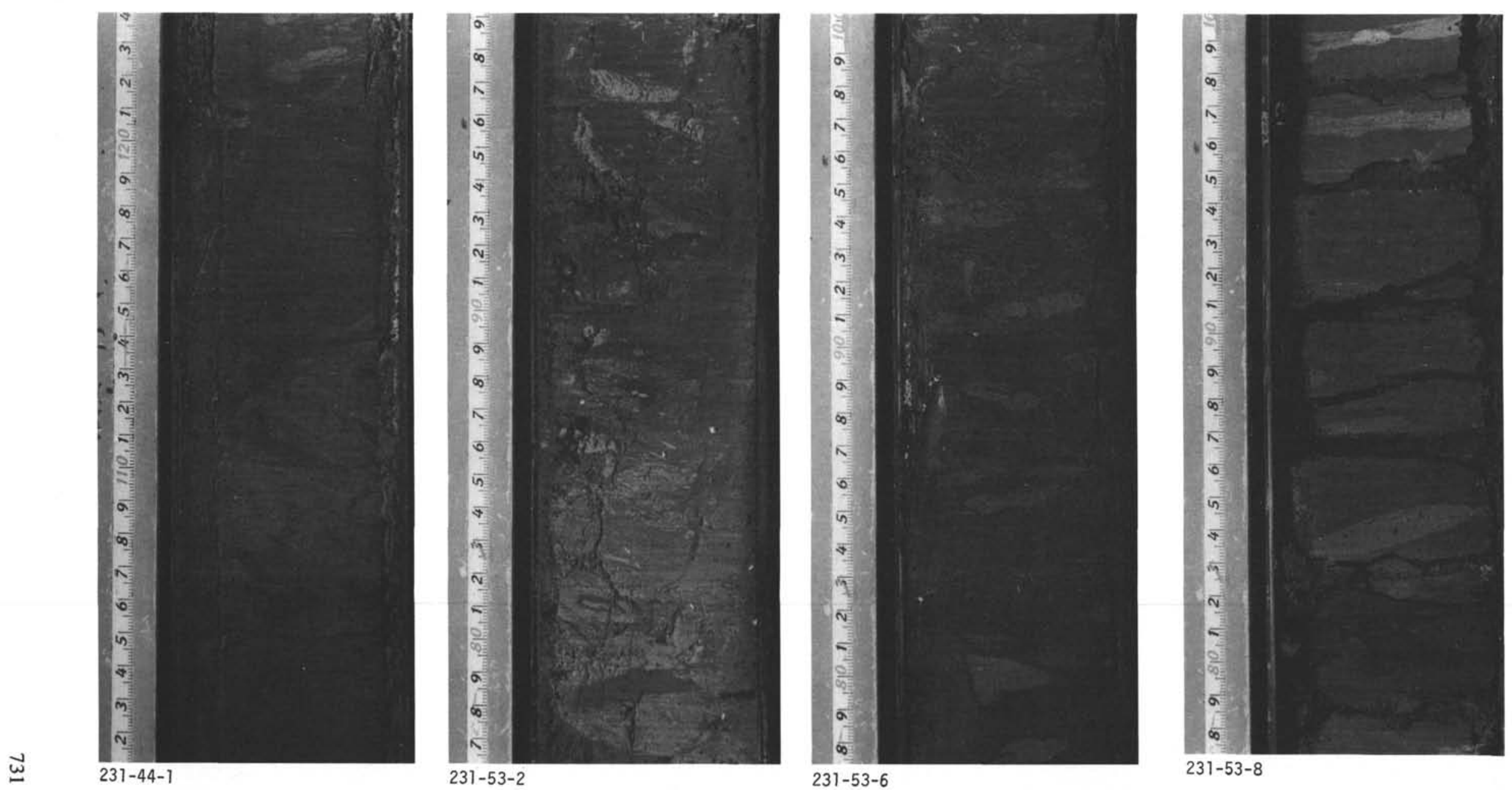

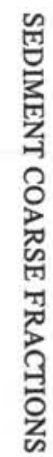




\section{PLATE 3}

Basal sediments of Hole 232A.

Figure 1 Sample $15 \mathrm{~A}-2,55-59 \mathrm{~cm}$. Thin section; upper Miocene terrigenous sediments mainly composed of angular quartz fragments dispersed in a clayey pyritic matrix.

Figures 2, 3 Sample 17A, CC. Shipboard thin section; upper Miocene fine-grained quartzitic sandstone composed mainly of angular to round quartz grains and a small percentage of heavy minerals.

Figures 4-6 Sample 27A-100 cm. Shipboard thin section; upper Miocene quartzitic sandstone, presumably representing the acoustic basements on the northwestern flank of the Gulf of Aden. Remark diverse mineral composition of quartz, silicates, and carbonates.

4. Rounded basic volcanic fragments.

5. Fragments of fossils.

6. Foraminiferal shell. 


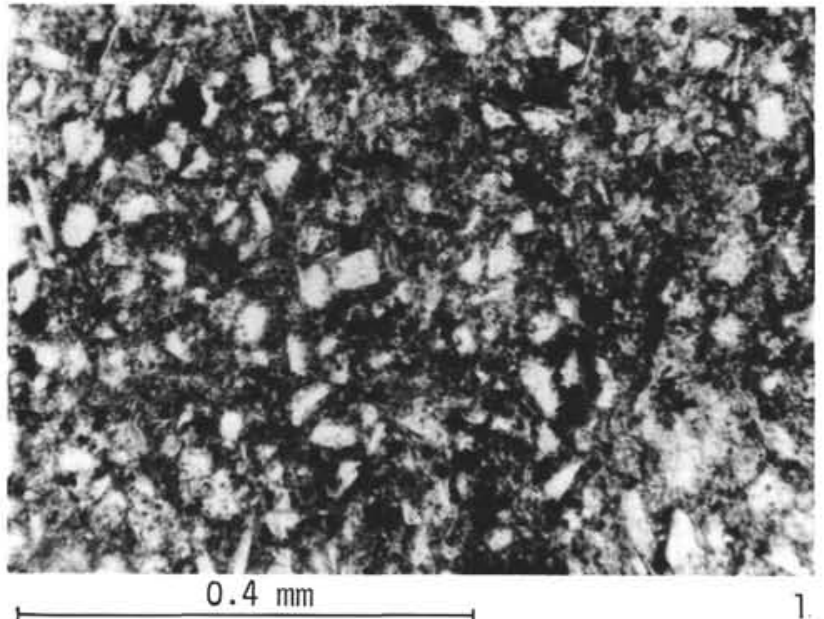

$232 A-15-2(55-59)$

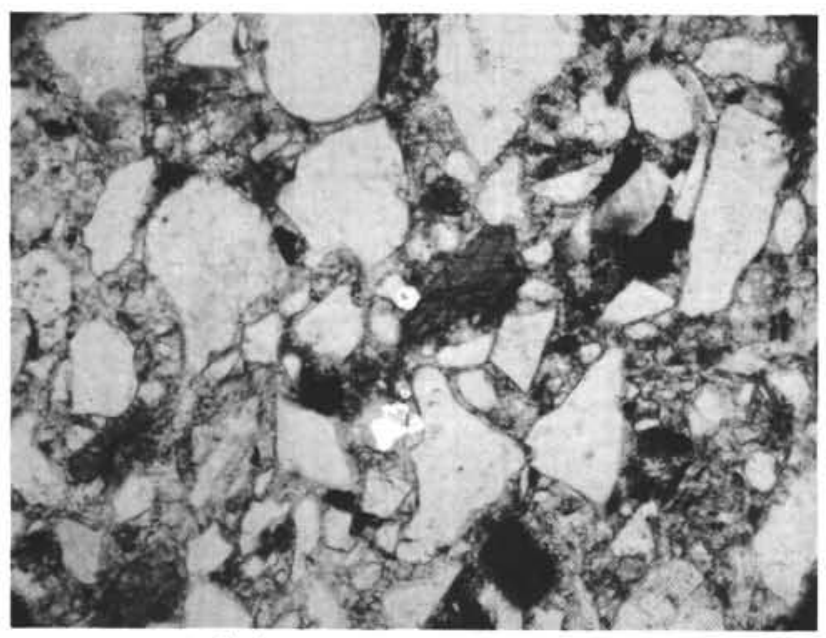

232A-17-CC

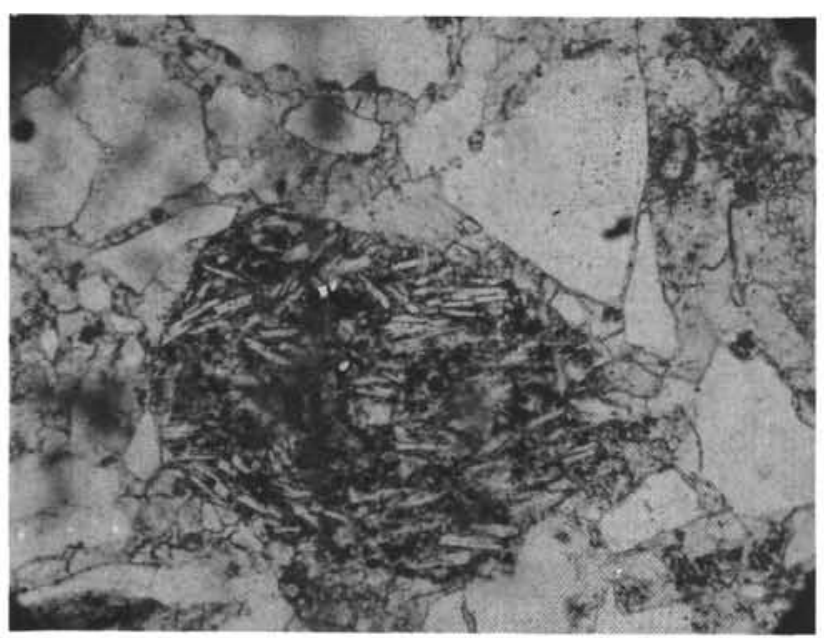

$0.2 \mathrm{~mm}$

$232 A-27-1$
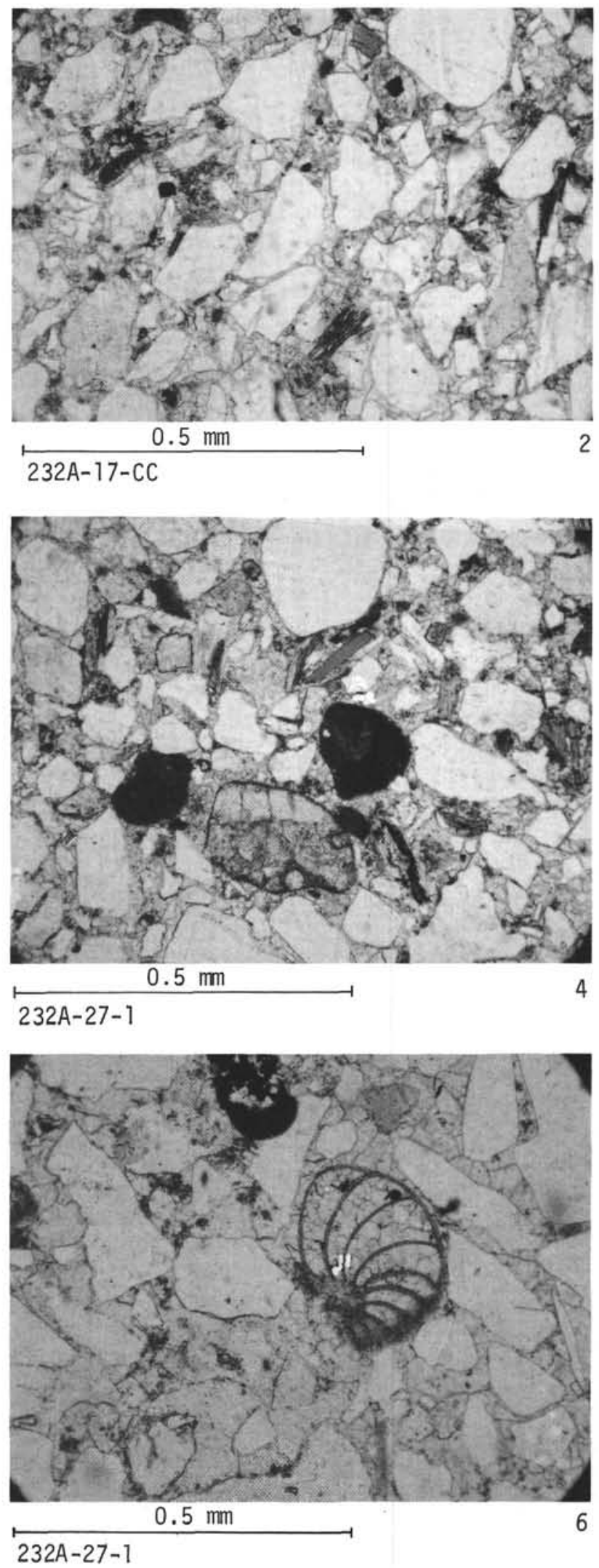


\section{PLATE 4}

Sediments at Site 233. Smear slides.

Figures 1,2 Sample 1-3, $90 \mathrm{~cm}$. Quaternary sandy nanno ooze. Matrix consists mainly of coccoliths. These sandy horizons contain a major portion of calcareous shells and terrigenous material.

Figure 3 Sample 1-4, $140 \mathrm{~cm}$. Quaternary nanno ooze with major portion of siliceous tests and sponge spicules. Remark dolomite rhomb with core.

Figure 4 Sample $7-1,80 \mathrm{~cm}$. Quaternary nanno ooze with major portion of siliceous tests and sponge spicules.

Figure 5 Sample $8-2,130 \mathrm{~cm}$. Quaternary nanno ooze.

Figure 6 Sample 10-4, $80 \mathrm{~cm}$. Homogeneous upper Pliocene nanno ooze. 
PLATE 4

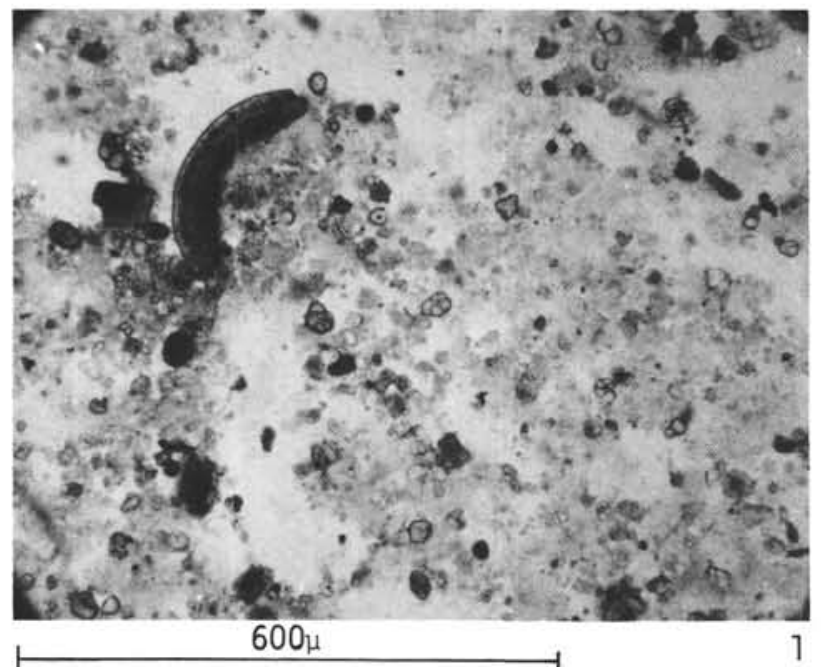

233-1-3-90

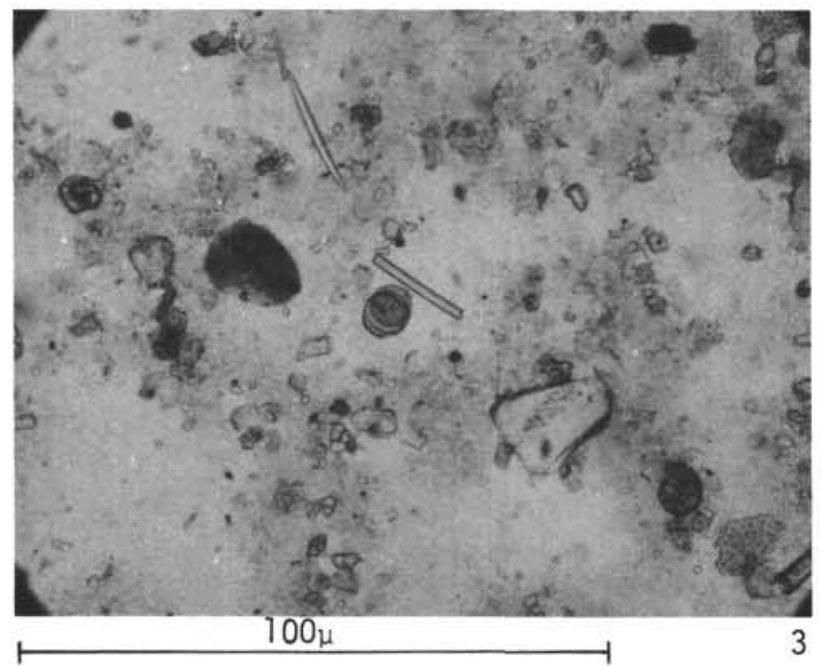

233-1-4-40

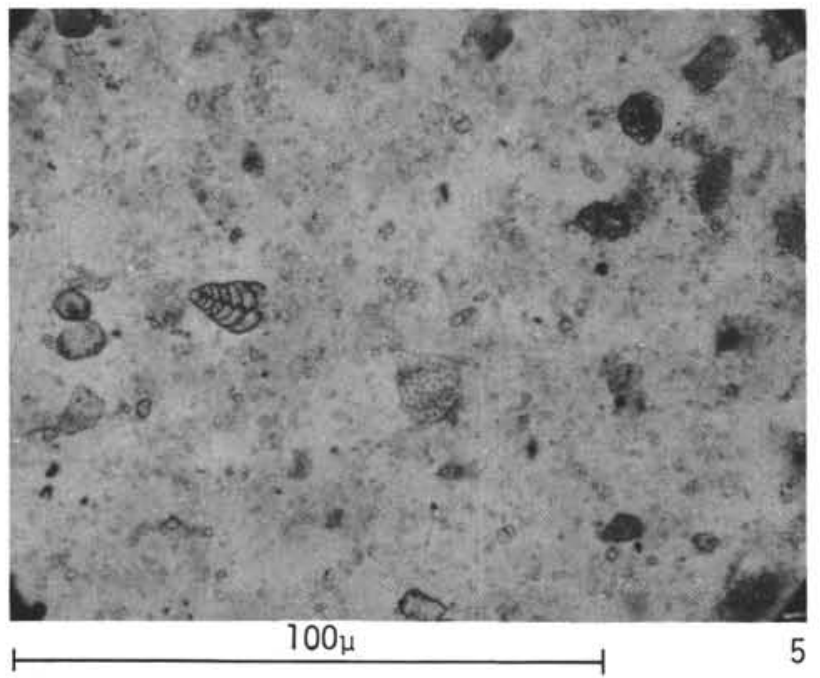

$233-8-2-130$

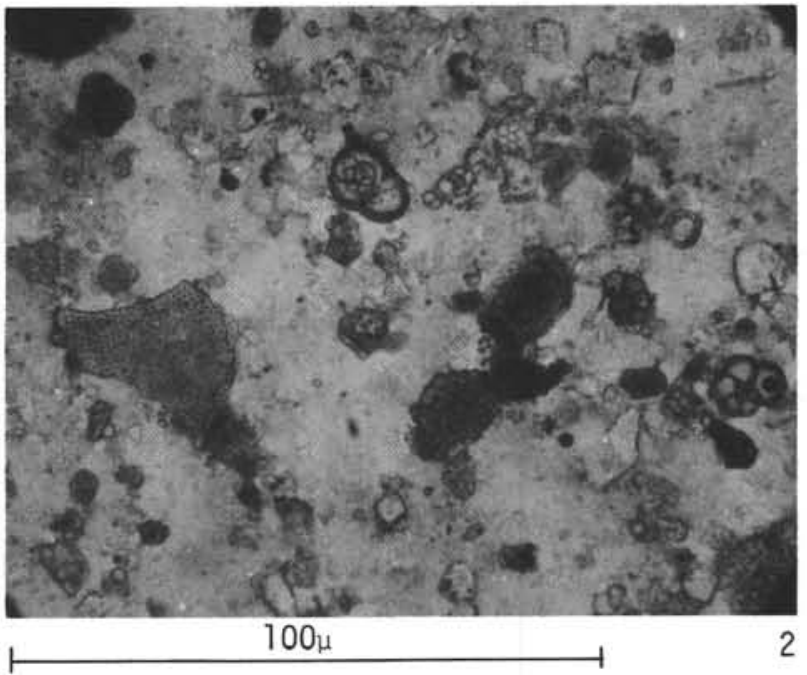

233-1-3-90

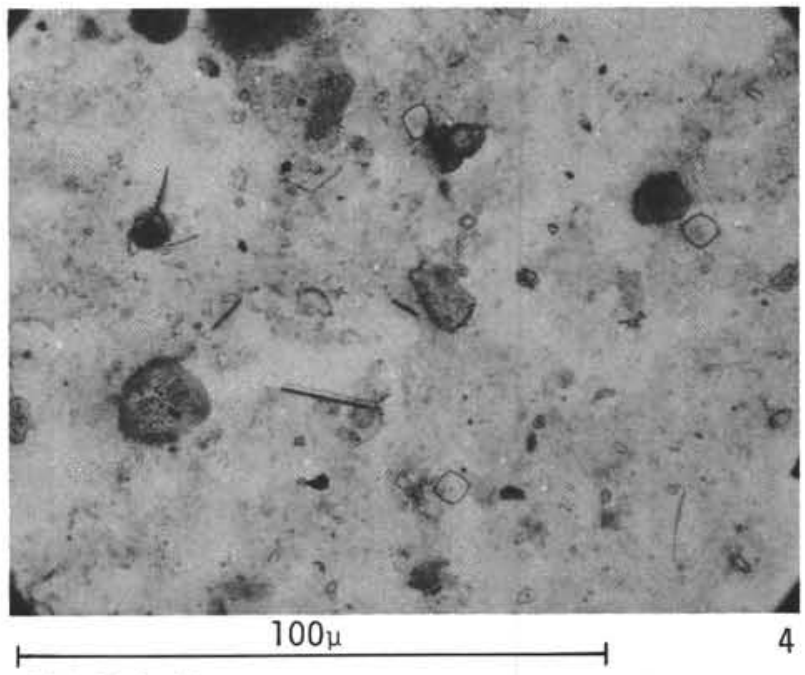

233-7-1-80

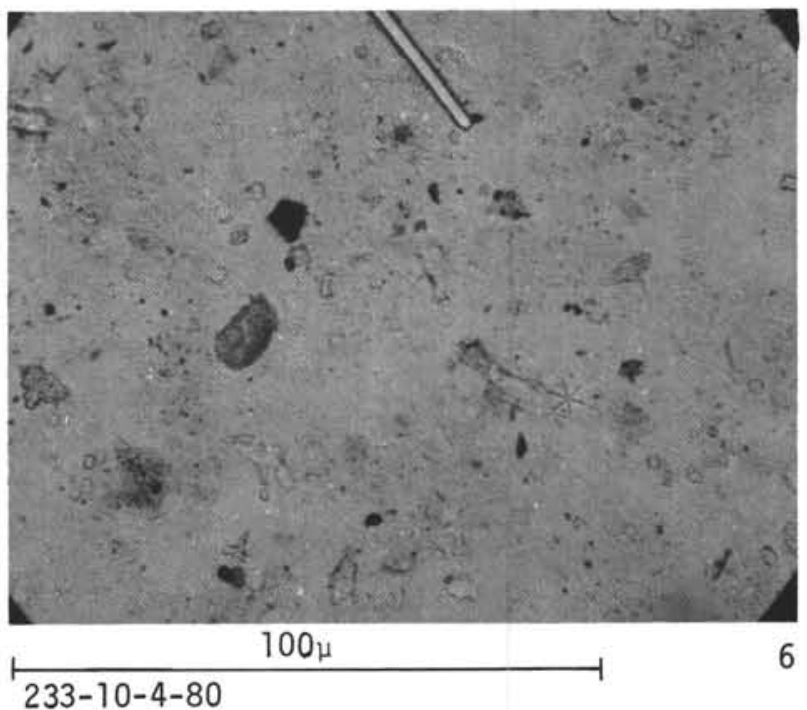




\section{PLATE 5}

Sediments at Site 233. Smear slides.

Figure 1 Sample $20-4,80 \mathrm{~cm}$. Upper Pliocene nanno ooze with siliceous components. Remark dolomite rhomb with typical core.

Figure 2 Sample 13-3, $80 \mathrm{~cm}$. Upper Pliocene nanno ooze with discoasters, dolomite rhombs, and a certain fraction of terrigenous minerals.

Figure 3 Sample $15-4,80 \mathrm{~cm}$. Upper Pliocene nanno ooze with broken skeletons of siliceous organisms.

Figure 4 Sample $16-3,80 \mathrm{~cm}$. Upper Pliocene nanno ooze, rich in discoasters, with a certain portion of terrigenous material.

Figure 5 Sample 5A-3, $48 \mathrm{~cm}$. Lowermost upper Pliocene nanno ooze (matrix) with big terrigenous grain of quartz and heavy minerals.

Figure 6 Sample 7A-5, $80 \mathrm{~cm}$. Lower Pliocene silt nanno ooze. 


\section{PLATE 5}
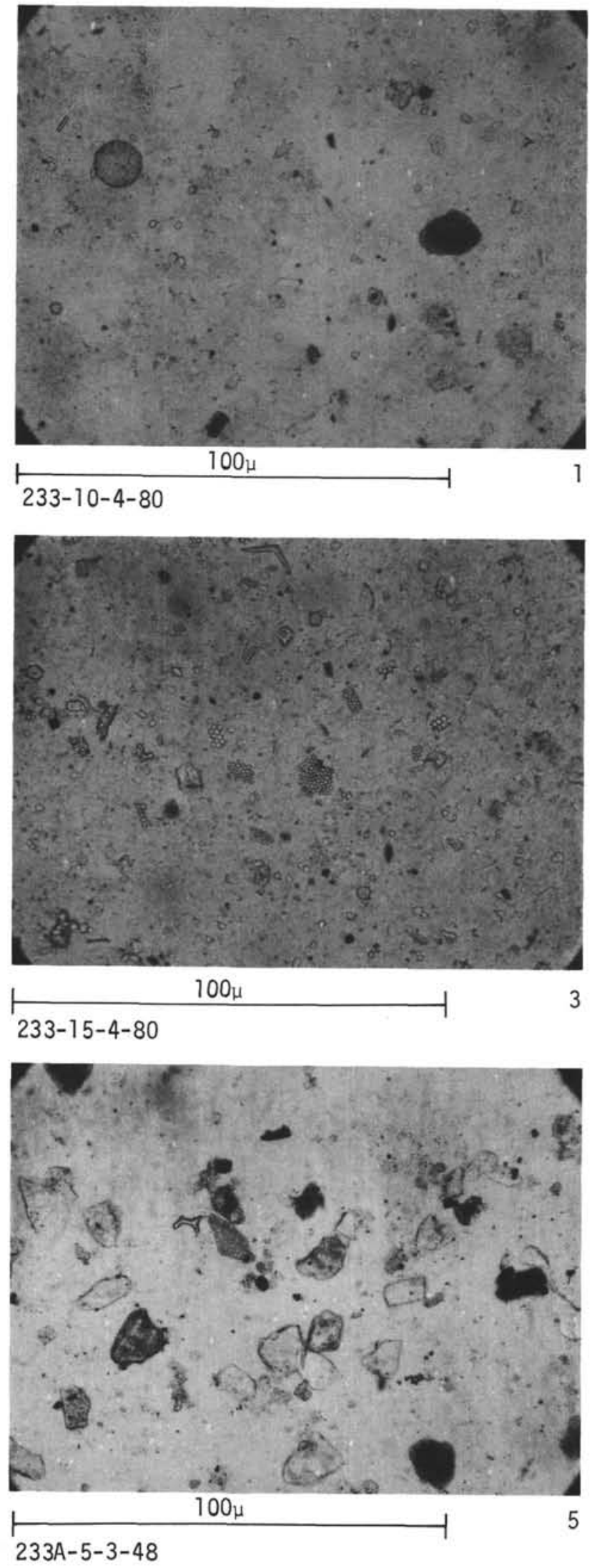
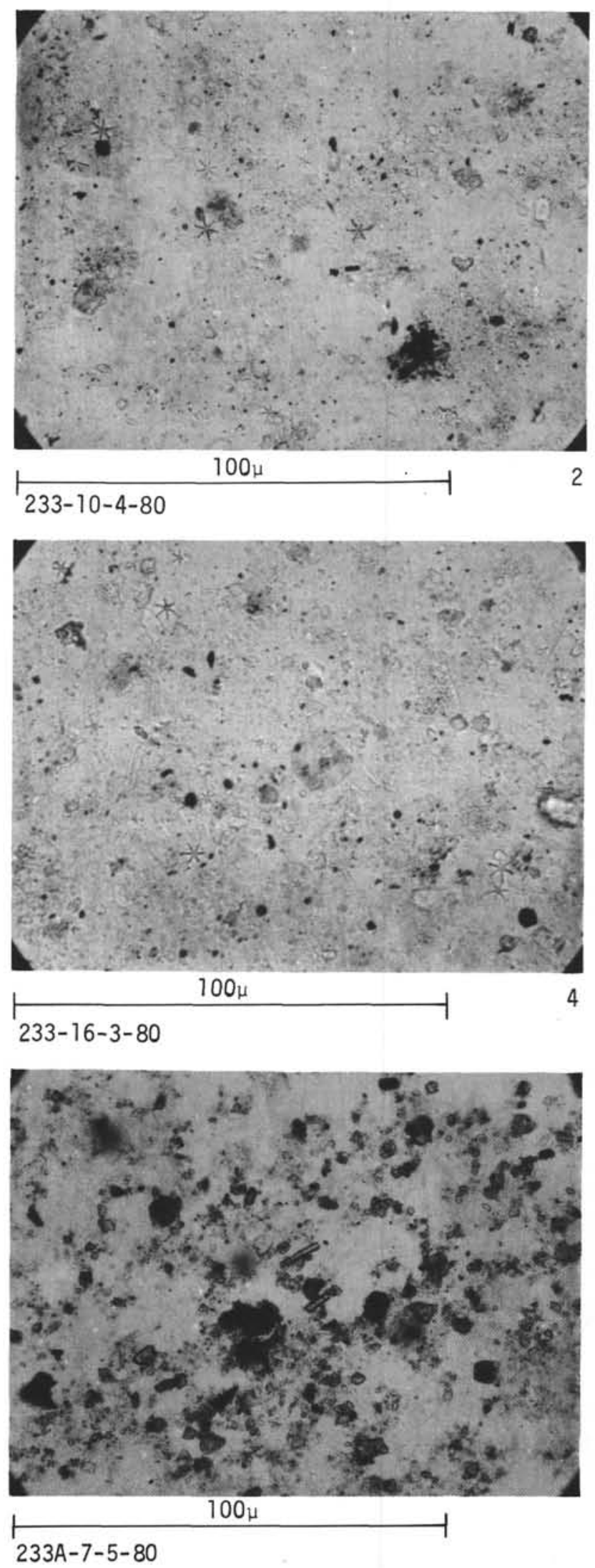


\section{PLATE 6}
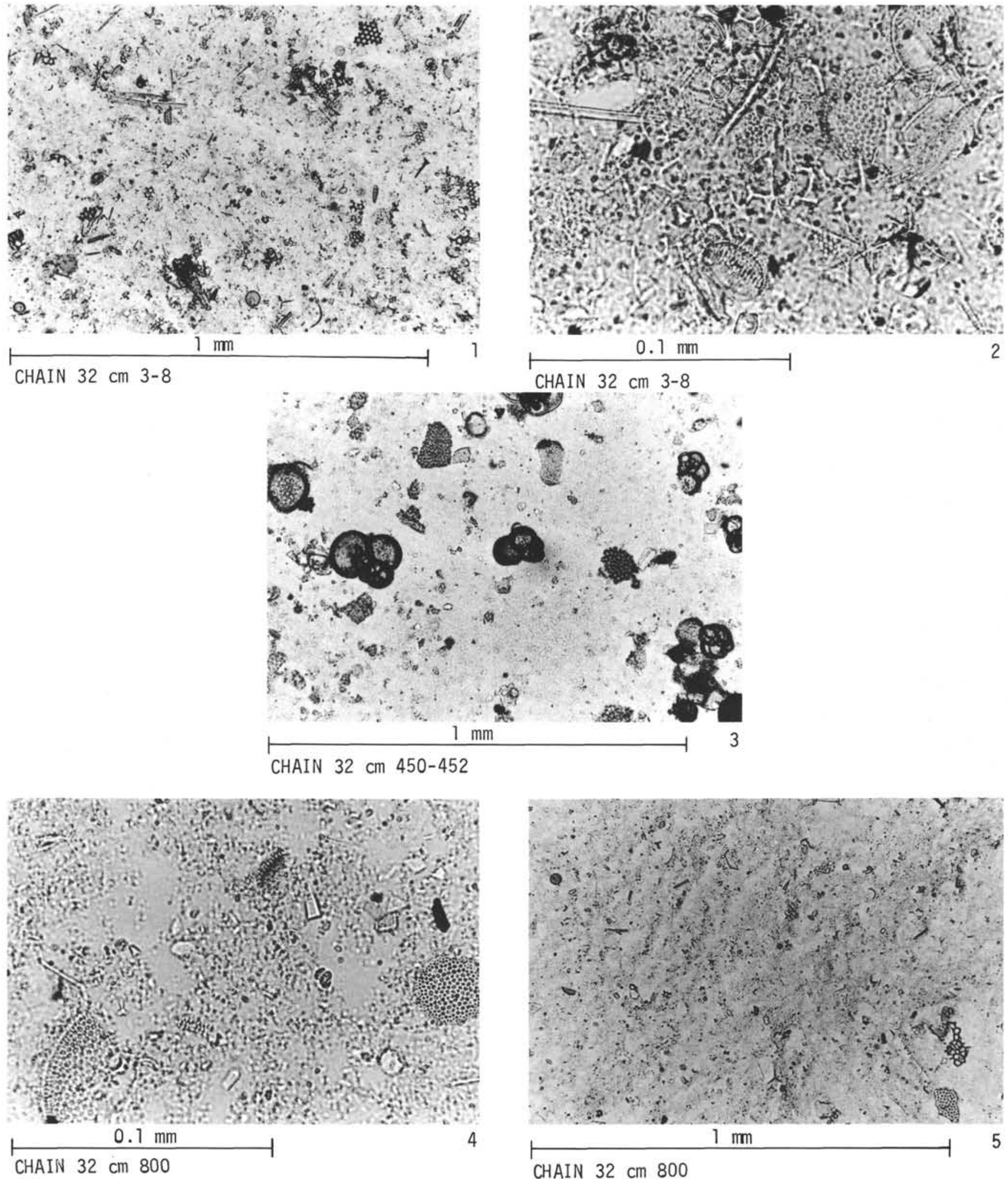

Surface and subsurface sediments at Site 235 (smear slides).

Figures 1,2 Chain 100/32 P cm 3-8. Dominantly siliceous skeletons: diatoms, fragments of Radiolaria, sponge spicules.

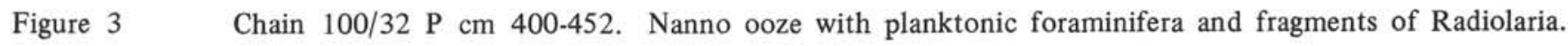
Figures 4, 5 Chain $100 / 32 \mathrm{P} \mathrm{cm} \mathrm{800.} \mathrm{Nanno} \mathrm{ooze} \mathrm{with} \mathrm{high} \mathrm{proportion} \mathrm{of} \mathrm{siliceous} \mathrm{skeletons.}$ 
PLATE 7
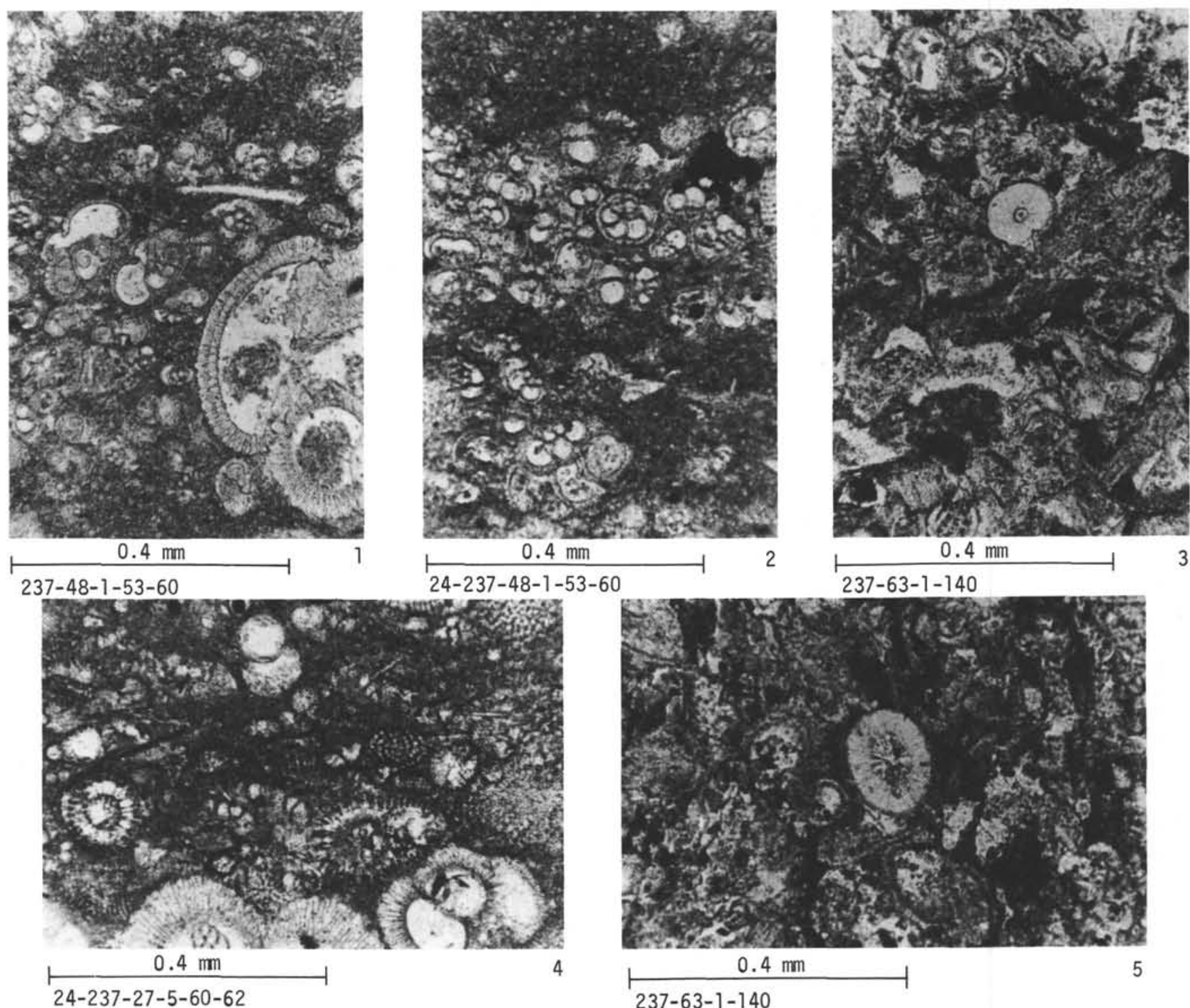

$0.4 \mathrm{~mm}$

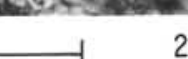

$237-63-1-140$

Sediments at Site 237 (all thin sections).

Figures 1, 2 Sample 48-1, 53-60 cm. Upper Paleocene foraminiferal nannofossil chalk. The planktonic foraminifera are well preserved and are found enriched in thin layers wedging out to the site (resembling small lenses).

Figures 3, 5 Sample $63-1,140 \mathrm{~cm}$. Paleocene chalk with excellent preserved Radiolaria.

Figure 4

Sample 27-5, 60-62 cm. Middle Eocene nannofossil ooze very rich in thick-walled planktonic foraminifera and well-preserved Radiolaria. 


\section{PLATE 8}

Sediments of Site 238 (thin sections).

Figures 1-3 Sample 48-2, 40-44 cm. Lower Miocene/upper Oligocene nannofossil chalk with many planktonic foraminifera, which are found in small lens-formed units.

Figure 4 Sample 50-3, 25-30 cm. Upper Oligocene nannofossil chalk.

Figures 5,6 Sediment inclusions in the basalt. Heavily recrystallized nannofossil (?) chalk.

5. Sample $60-3,1 \mathrm{~cm}$.

6. Sample $64-1,6 \mathrm{~cm}$. Glassy rim of the basalt. 

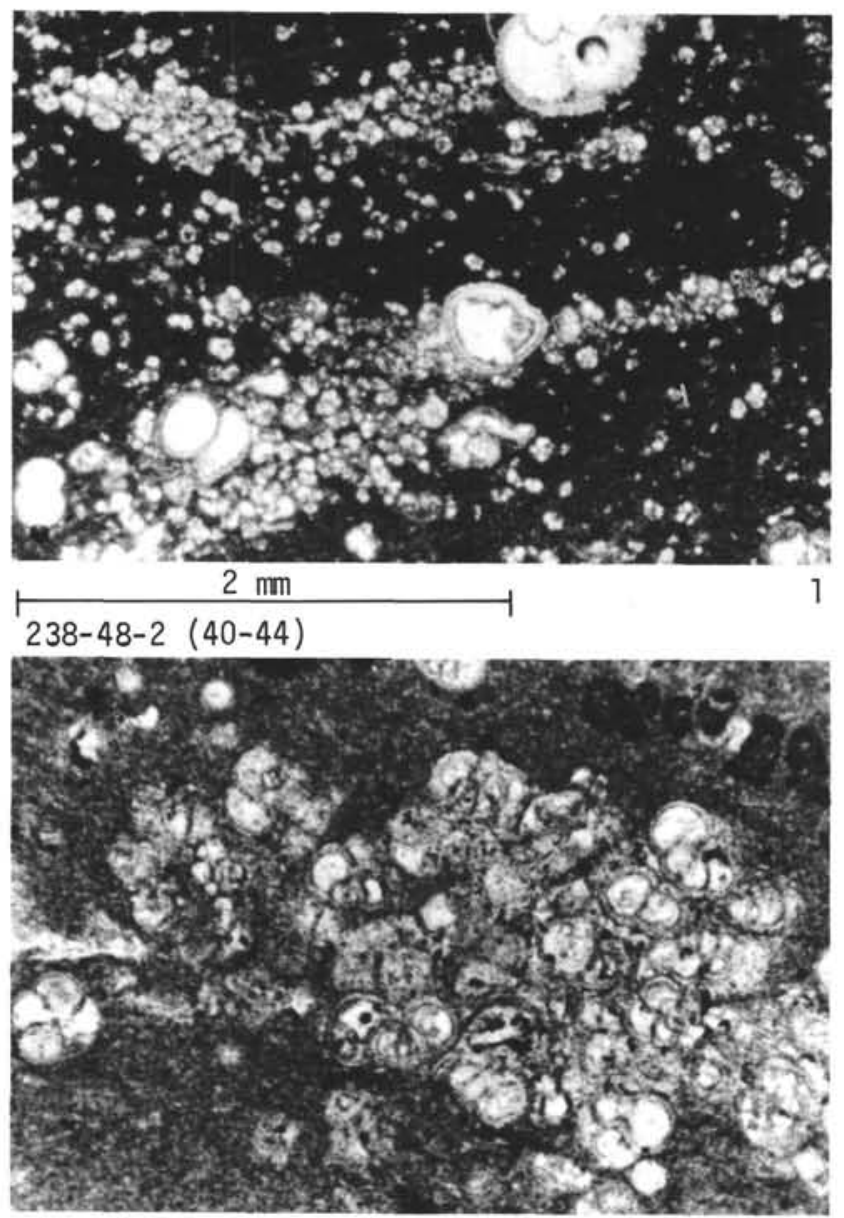

24-238-48-2 (40-44)

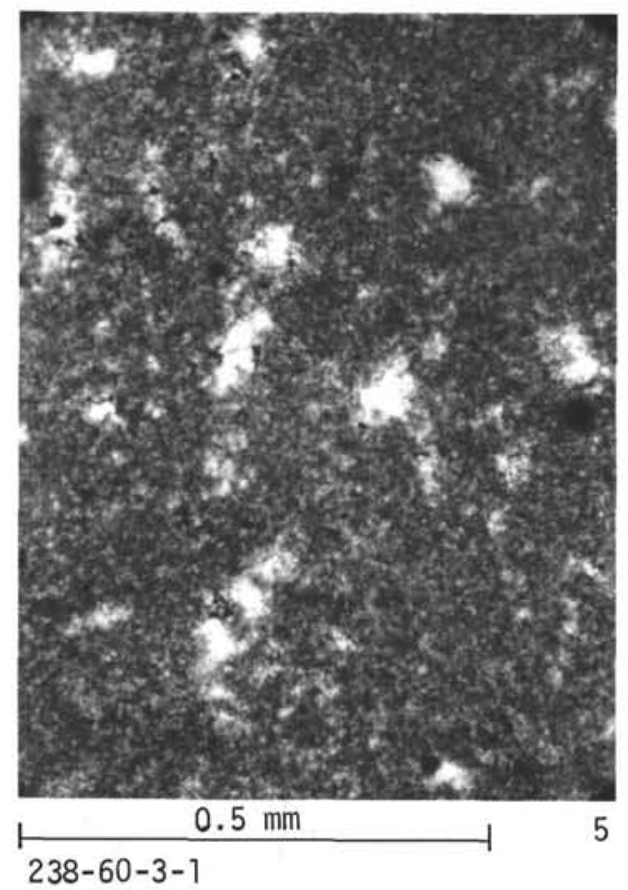

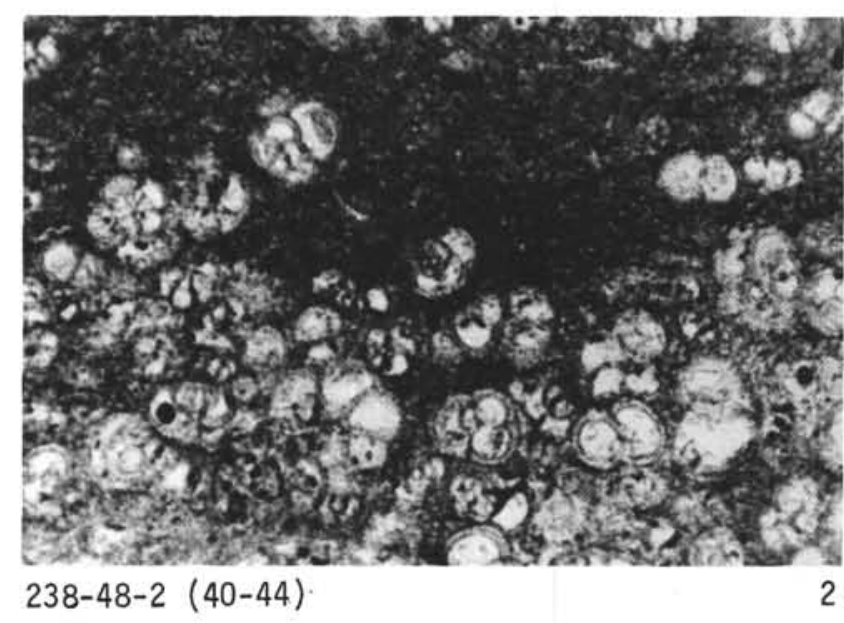
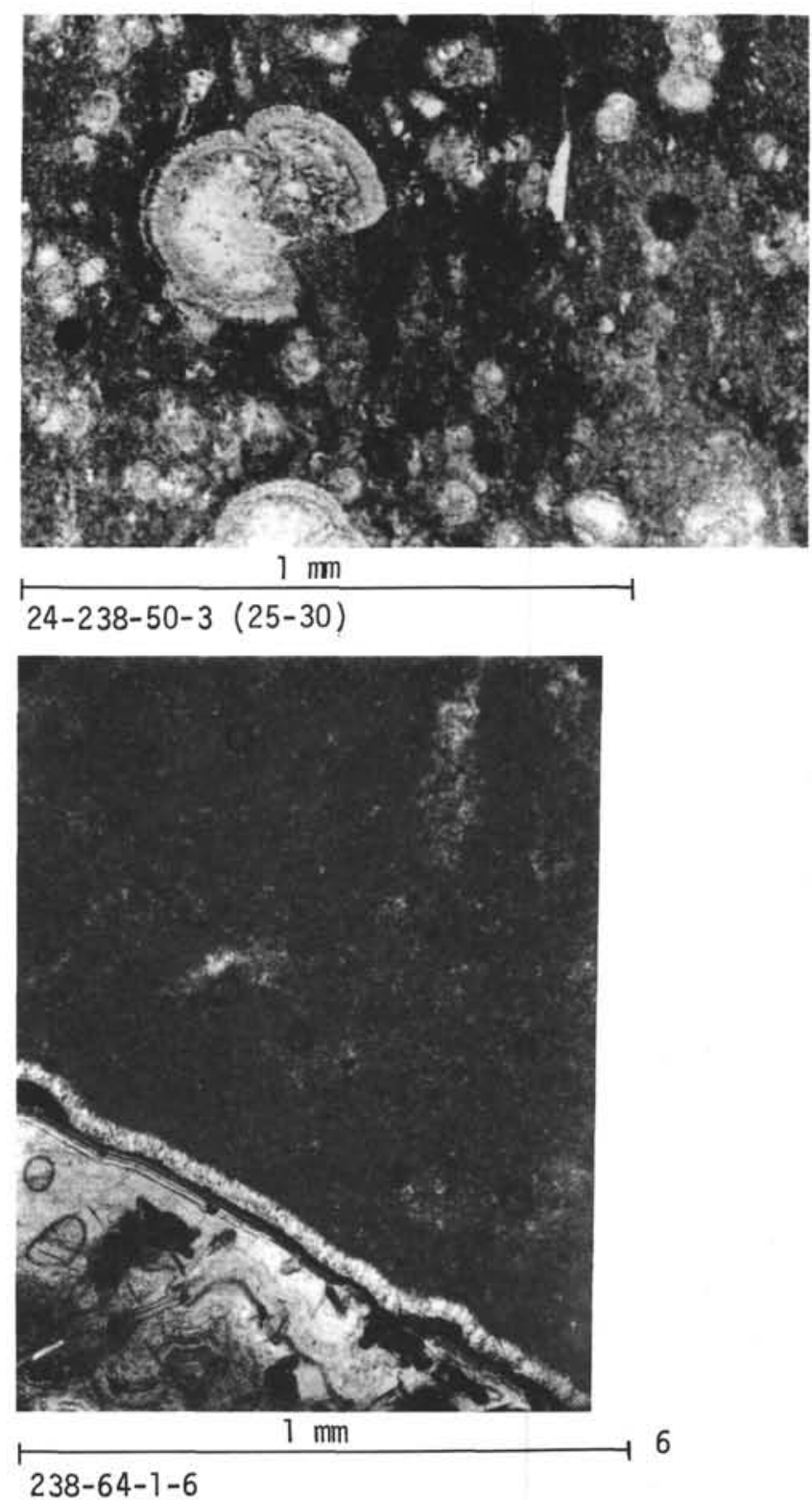


\section{PLATE 9}

Sediment inclusions in the basaltic basement of Site 238 (shipboard thin sections).

Figures 1-3 Lower Oligocene (?) heavily recrystallized nannofossil chalk with fragments and tests of foraminifera.

1. Sample $57-3,6 \mathrm{~cm}$.

2. Sample $57-2,6 \mathrm{~cm}$.

3. Sample 57-56.

Figures 4-6 Lower Oligocene (?) heavily recrystallized nannofossil chalk with few recognizable fossil fragments. Pelletlike structures are of unknown origin. Sample 58-4, $6 \mathrm{~cm}$.

4. Glassy rim of the basalt. 


\section{PLATE 9}

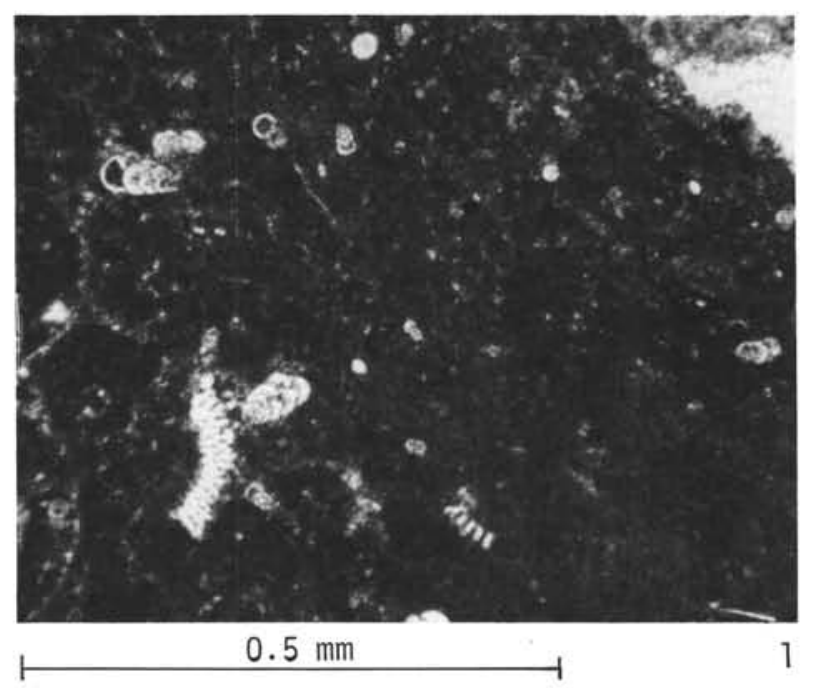

$238-57-3-6$
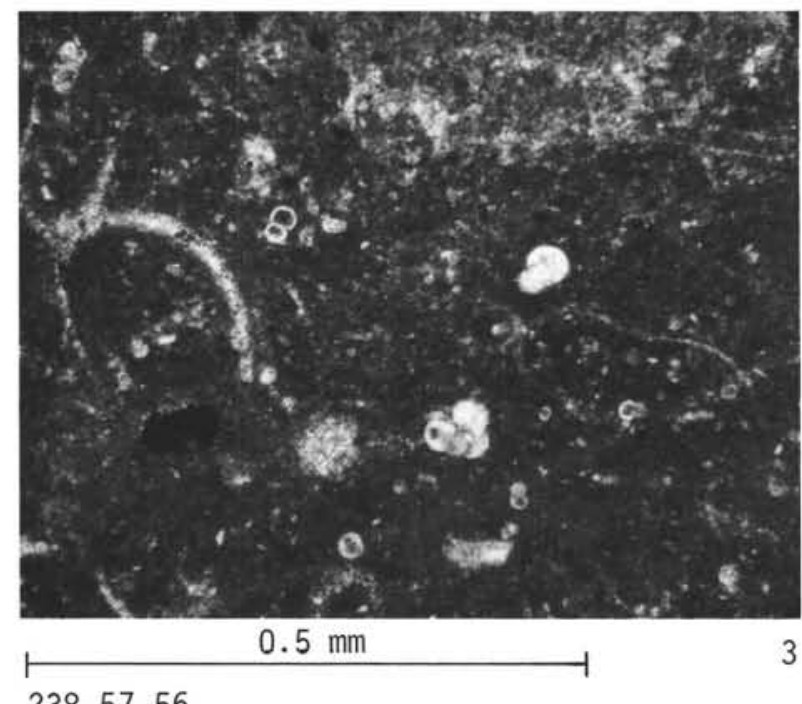

\section{$238-57-56$}

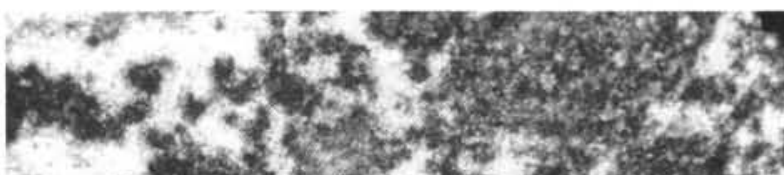

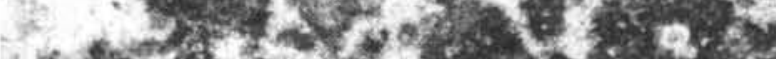

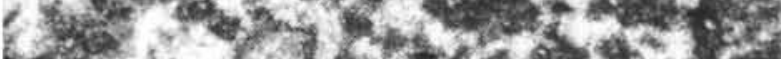

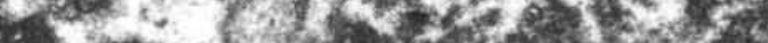

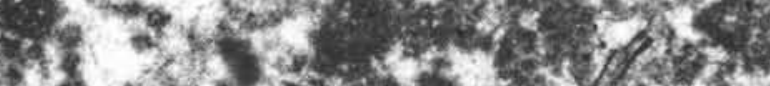

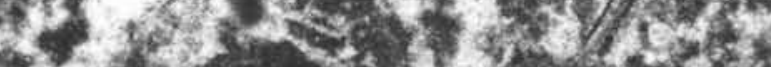

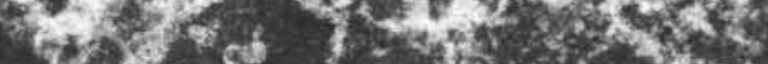

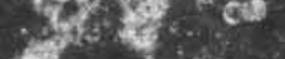

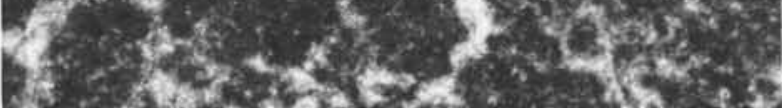
$1 \mathrm{~mm}$

$238-58-4-6$

$$
1 \mathrm{~mm}
$$

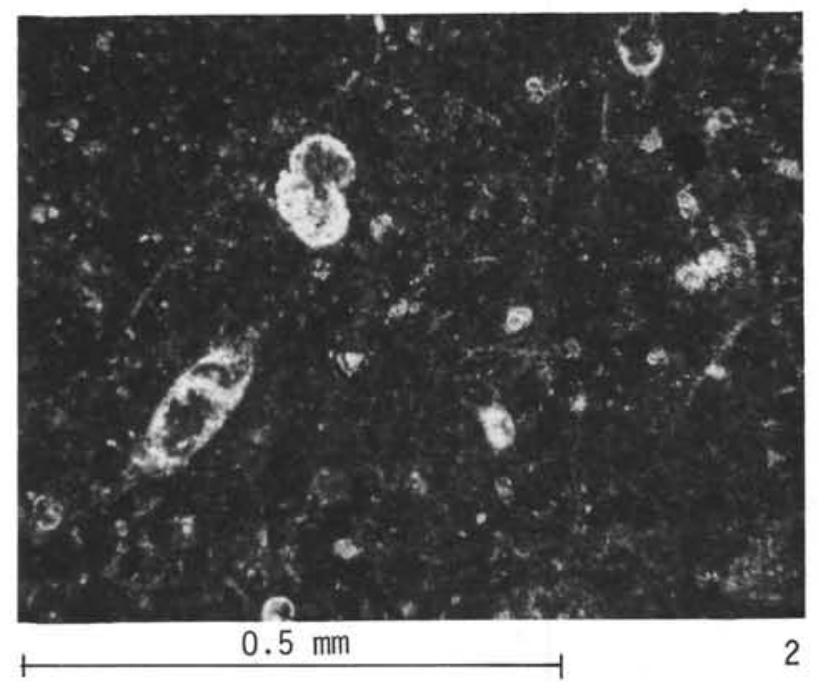

238-57-2-6
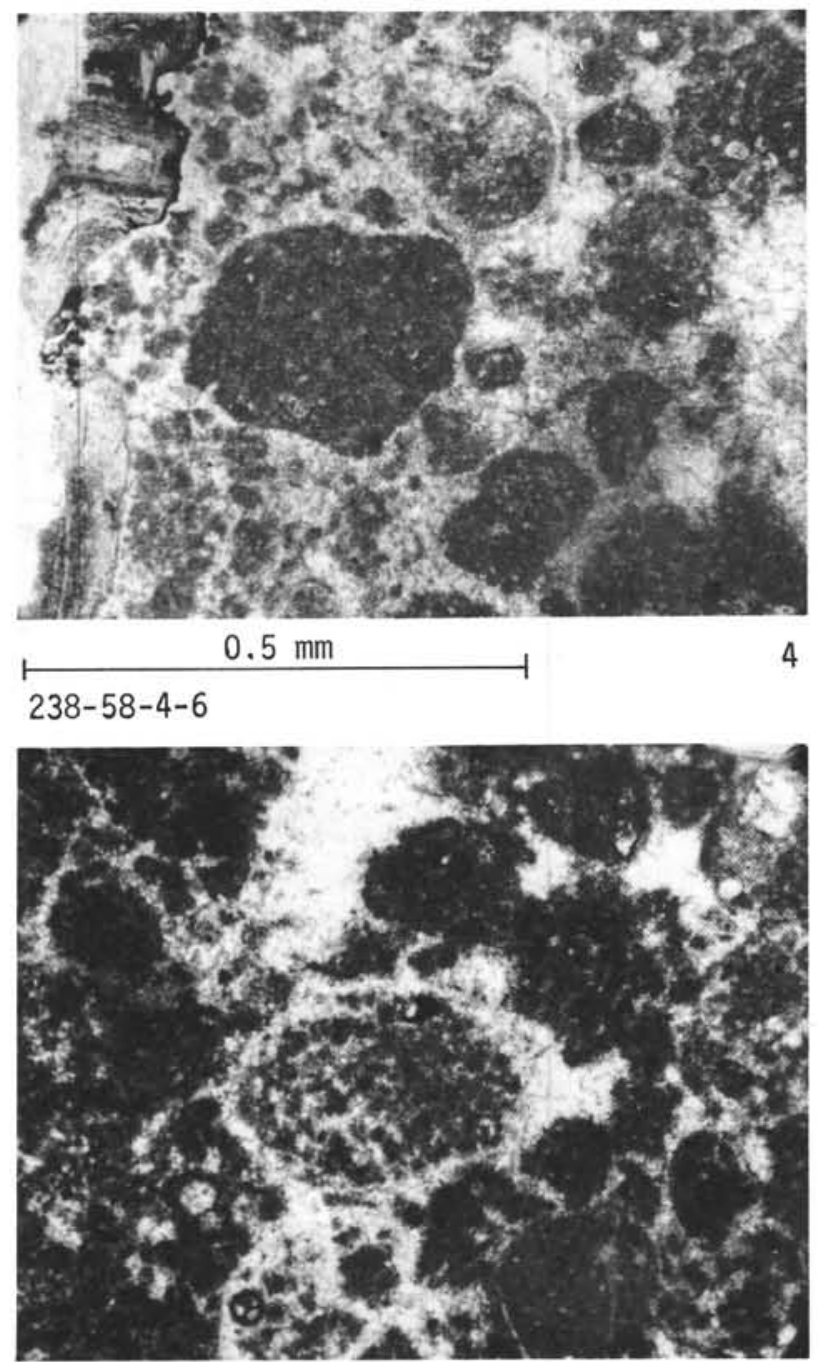

$238-58-4-6$ 


\section{J. THIEDE}

APPENDIX A

Data of Coarse Fraction Analysis

APPENDIX A

Data of Coarse Fraction Analy sis of CHAIN and ANTIPODE Stations Close to DSDP Leg 24 Drill Sites

\begin{tabular}{|c|c|c|c|c|c|c|c|c|c|c|c|c|c|c|c|c|c|c|c|c|c|c|c|c|c|}
\hline Samples & 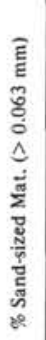 & $\begin{array}{l}\frac{y}{5} \\
\text { है } \\
82\end{array}$ & 这 & 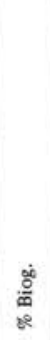 & $\frac{\overrightarrow{\mathrm{v}}}{\underline{E}}$ & 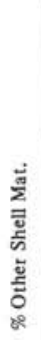 & 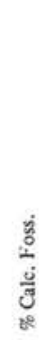 & 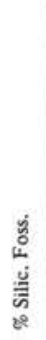 & 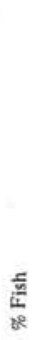 & 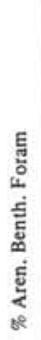 & $\begin{array}{l}\frac{n}{5} \\
\frac{0}{0} \\
\frac{0}{2} \\
\frac{d}{2} \\
0 R\end{array}$ & 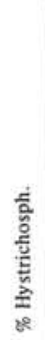 & 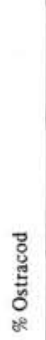 & 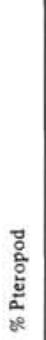 & 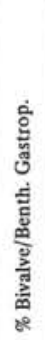 & 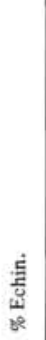 & 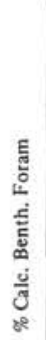 & 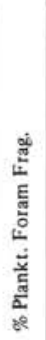 & 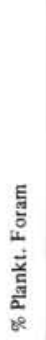 & 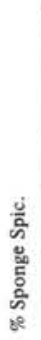 & 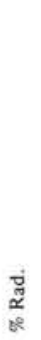 & 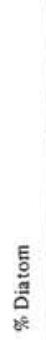 & 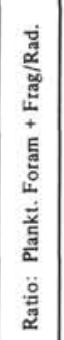 & 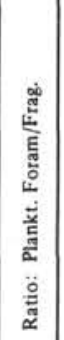 & 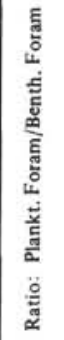 \\
\hline $\begin{array}{l}\text { ANTP } 120,0-50 \mathrm{~cm} \\
\text { ANTP } 142,0-30 \mathrm{~cm} \\
\text { ANTP } 146,0-50 \mathrm{~cm} \\
\text { ANTP } 150,0-50 \mathrm{~cm}\end{array}$ & & & & $\begin{array}{l}100 \\
100 \\
100 \\
100\end{array}$ & & $\begin{array}{l}\mathrm{Tr} \\
\mathrm{Tr}\end{array}$ & $\begin{array}{r}92 \\
46 \\
100 \\
94\end{array}$ & $\begin{array}{r}8 \\
54 \\
6 \\
6\end{array}$ & $\begin{array}{l}\mathrm{Tr} \\
\mathrm{Tr}\end{array}$ & & & & & $\mathrm{Tr}$ & & $\mathrm{Tr}$ & $\begin{array}{l}\mathrm{Tr} \\
\mathrm{Tr} \\
\mathrm{Tr} \\
\mathrm{P}\end{array}$ & $\begin{array}{l}49 \\
17 \\
34 \\
68 \\
\end{array}$ & $\begin{array}{l}43 \\
29 \\
65 \\
22 \\
\end{array}$ & $\begin{array}{l}\mathrm{Tr} \\
\mathrm{P} \\
\mathrm{P} \\
\end{array}$ & $\begin{array}{r}8 \\
43 \\
5 \\
\end{array}$ & 8 & $\begin{array}{r}12 . \\
1 . \\
18 .\end{array}$ & $\begin{array}{r}.9 \\
1.7 \\
1.9 \\
33 . \\
\end{array}$ & $\begin{array}{r}112 . \\
58 . \\
68 . \\
11 . \\
\end{array}$ \\
\hline CHN $100-30,0-7 \mathrm{~cm}$ & 9 & $\mathrm{Tr}$ & & 100 & & & 16 & 84 & & & & & & $P$ & & & $\mathrm{Tr}$ & 9 & 4 & $\mathrm{Tr}$ & 83 & & .2 & .4 & 6. \\
\hline CHN $100-30,110 \mathrm{~cm}$ & 87 & $\mathrm{Tr}$ & & 99 & & $\operatorname{Tr}$ & 85 & 14 & $\mathrm{Tr}$ & & & & $\mathrm{Tr}$ & 18 & & $\mathrm{Tr}$ & 6 & 25 & 35 & 3 & 11 & & 5.5 & 1.4 & 6.5 \\
\hline $\begin{array}{l}\text { CHN } 100-30 \\
1108 \mathrm{~cm}\end{array}$ & $\mathbf{P}$ & $\mathrm{Tr}$ & & 99 & & $\operatorname{Tr}$ & 39 & 60 & $\mathrm{Tr}$ & & & & & & & P & & 35 & $\mathbf{P}$ & $\mathbf{P}$ & 59 & & .6 & .07 & 1.3 \\
\hline CHN $100-32,3-8 \mathrm{~cm}$ & $\mathbf{P}$ & & & 100 & & & $\mathbf{P}$ & 98 & & & & & & & & $\mathrm{Tr}$ & & $\mathrm{P}$ & $\mathrm{Tr}$ & $\operatorname{Tr}$ & 97 & & .02 & 3 & 1. \\
\hline $\begin{array}{l}\text { CHN } 100-32 \\
450-452 \mathrm{~cm}\end{array}$ & 42 & $\mathbf{P}$ & & 98 & & $\operatorname{Tr}$ & 67 & 33 & $\mathrm{Tr}$ & & & & & & & $\mathrm{Tr}$ & P & 30 & 35 & $\mathrm{P}$ & 31 & & 2.1 & 1.2 & 18. \\
\hline CHN $100-32,800 \mathrm{~cm}$ & $\mathrm{Tr}$ & 3 & $\mathrm{Tr}$ & 96 & $\mathrm{Tr}$ & $\mathbf{P}$ & 35 & 64 & $\mathrm{Tr}$ & & $\mathrm{Tr}$ & & & & & & $\mathrm{Tr}$ & 7 & 27 & 4 & 60 & & .6 & 4. & 36. \\
\hline
\end{tabular}


APPENDIX $A_{2}$

Data of Coarse Fraction Analysis of DSDP Leg 24 Drill Sites

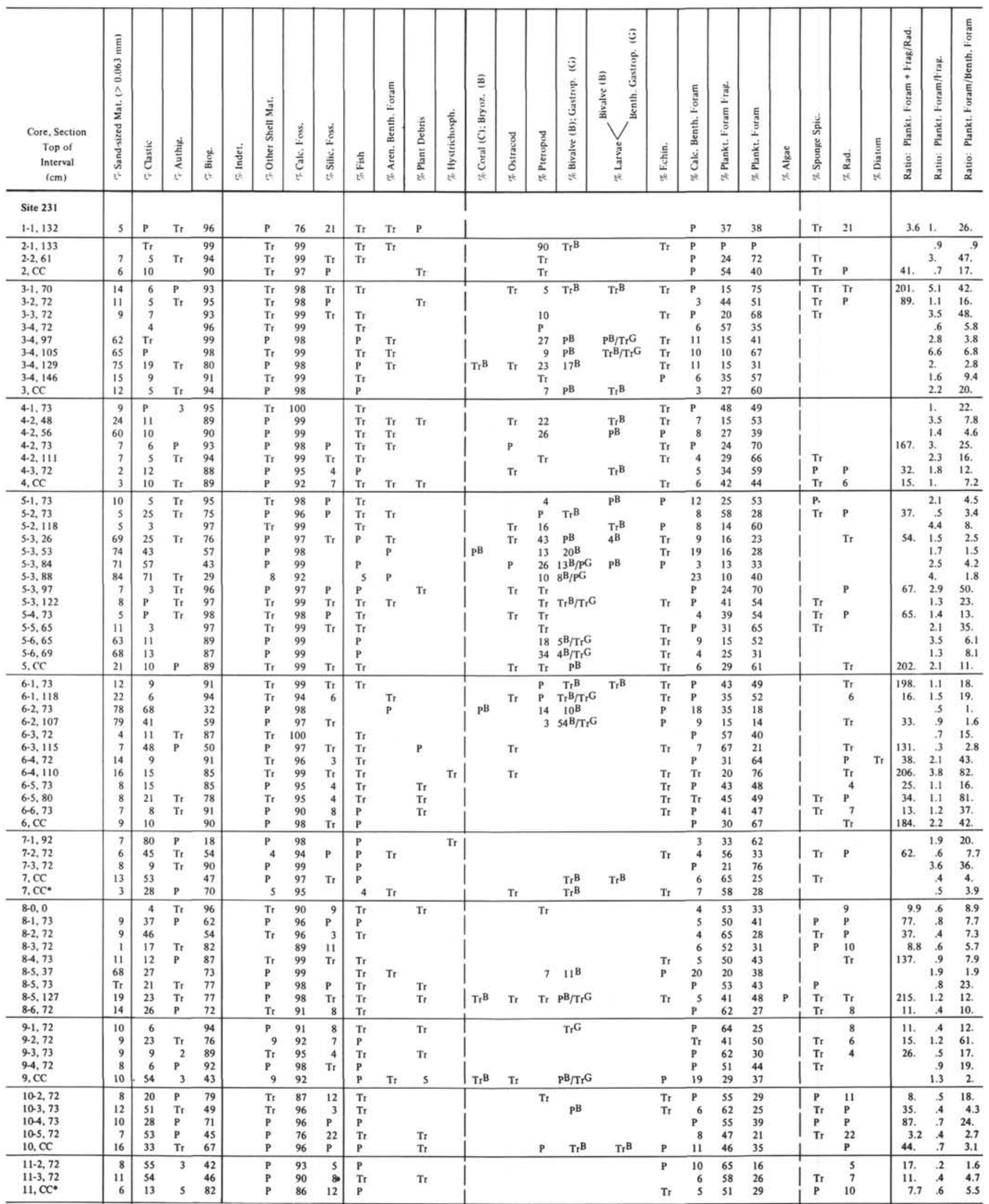




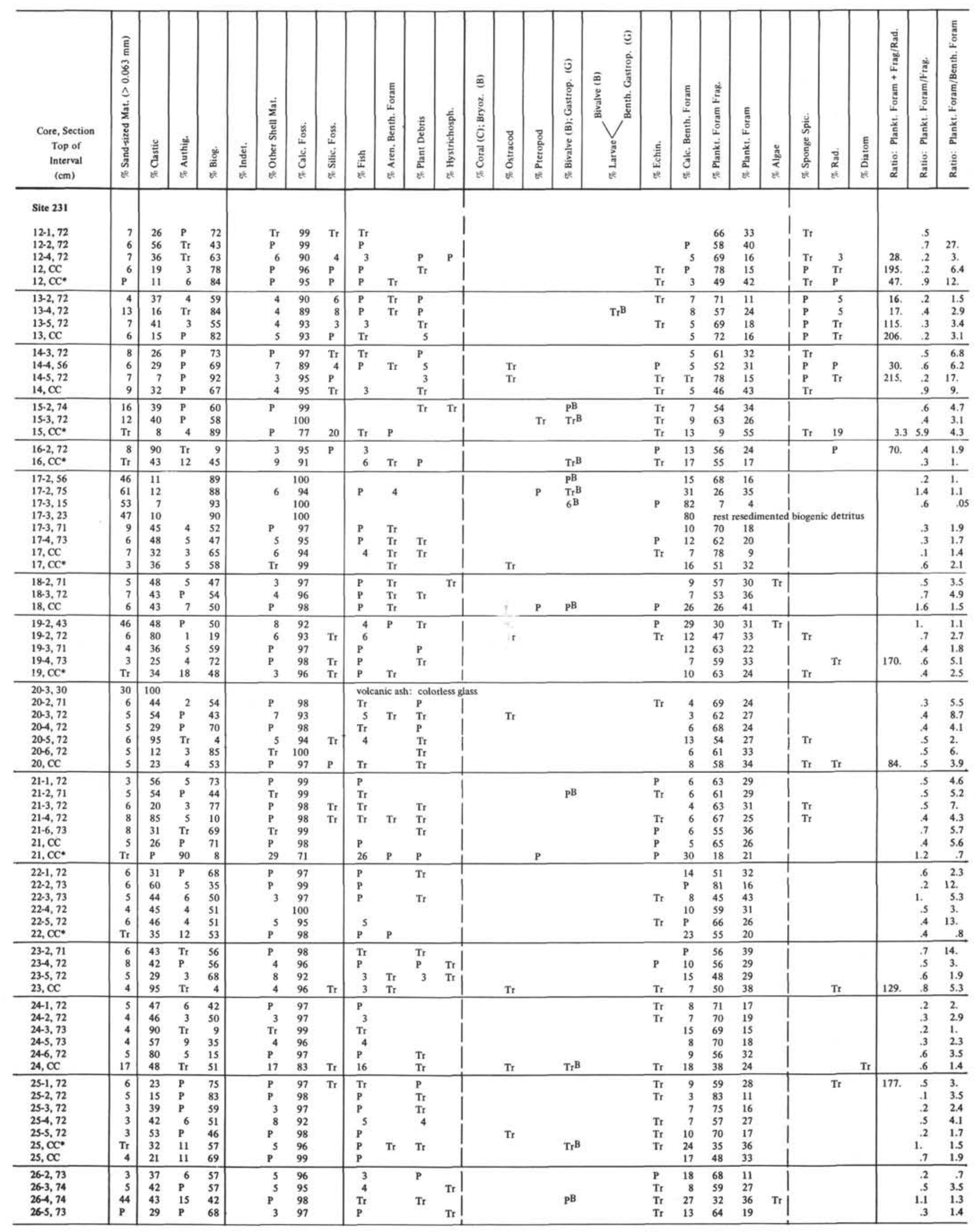




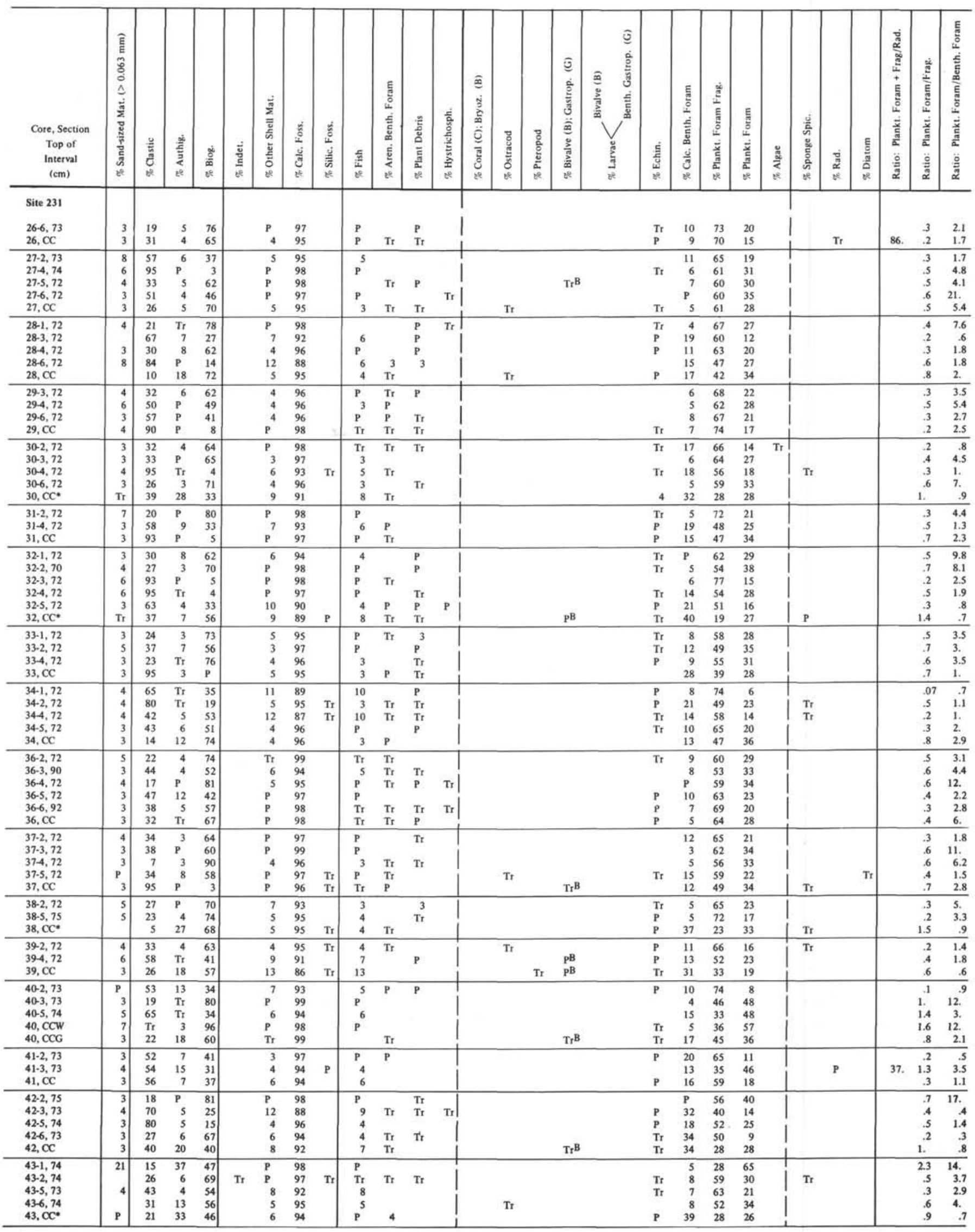




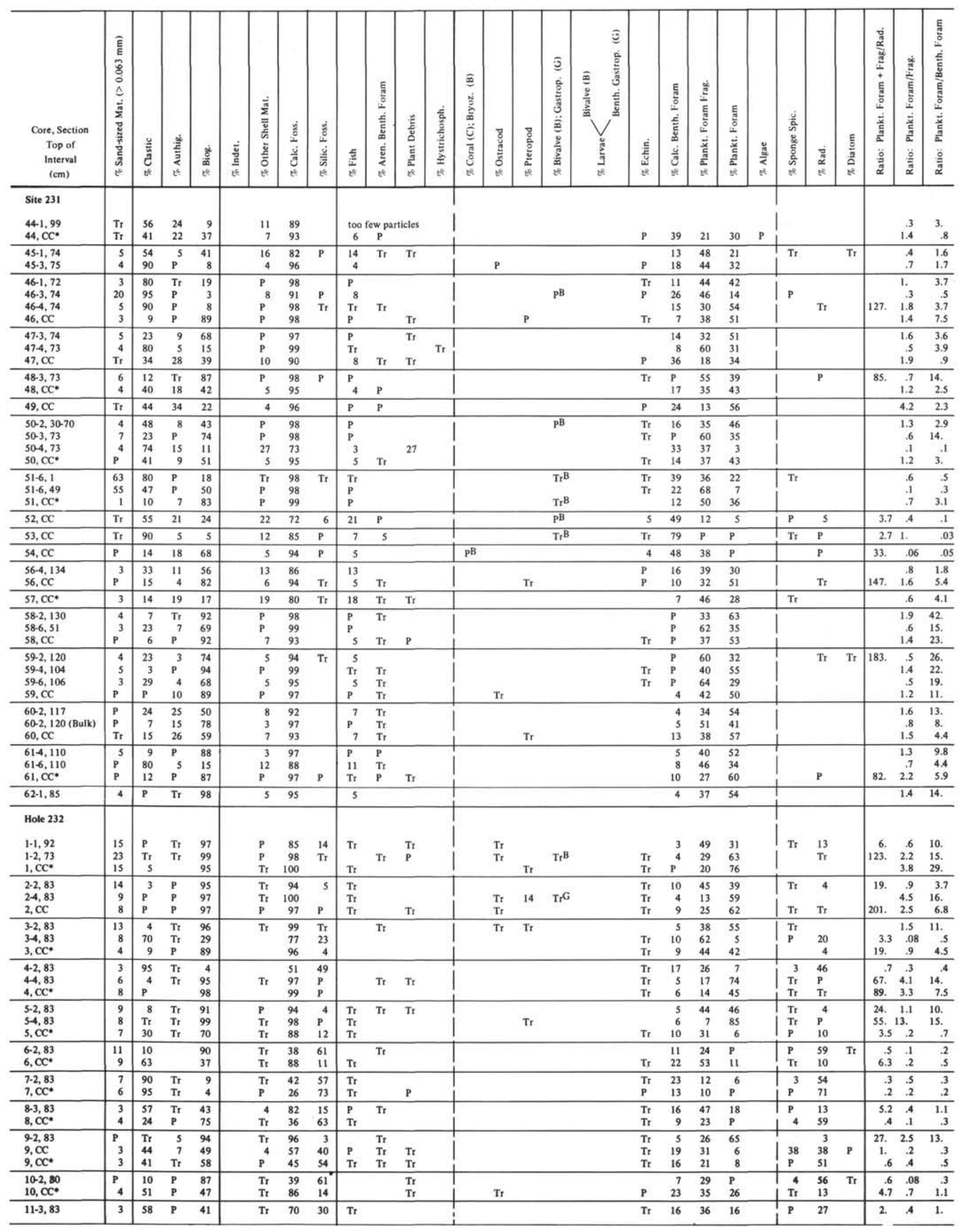




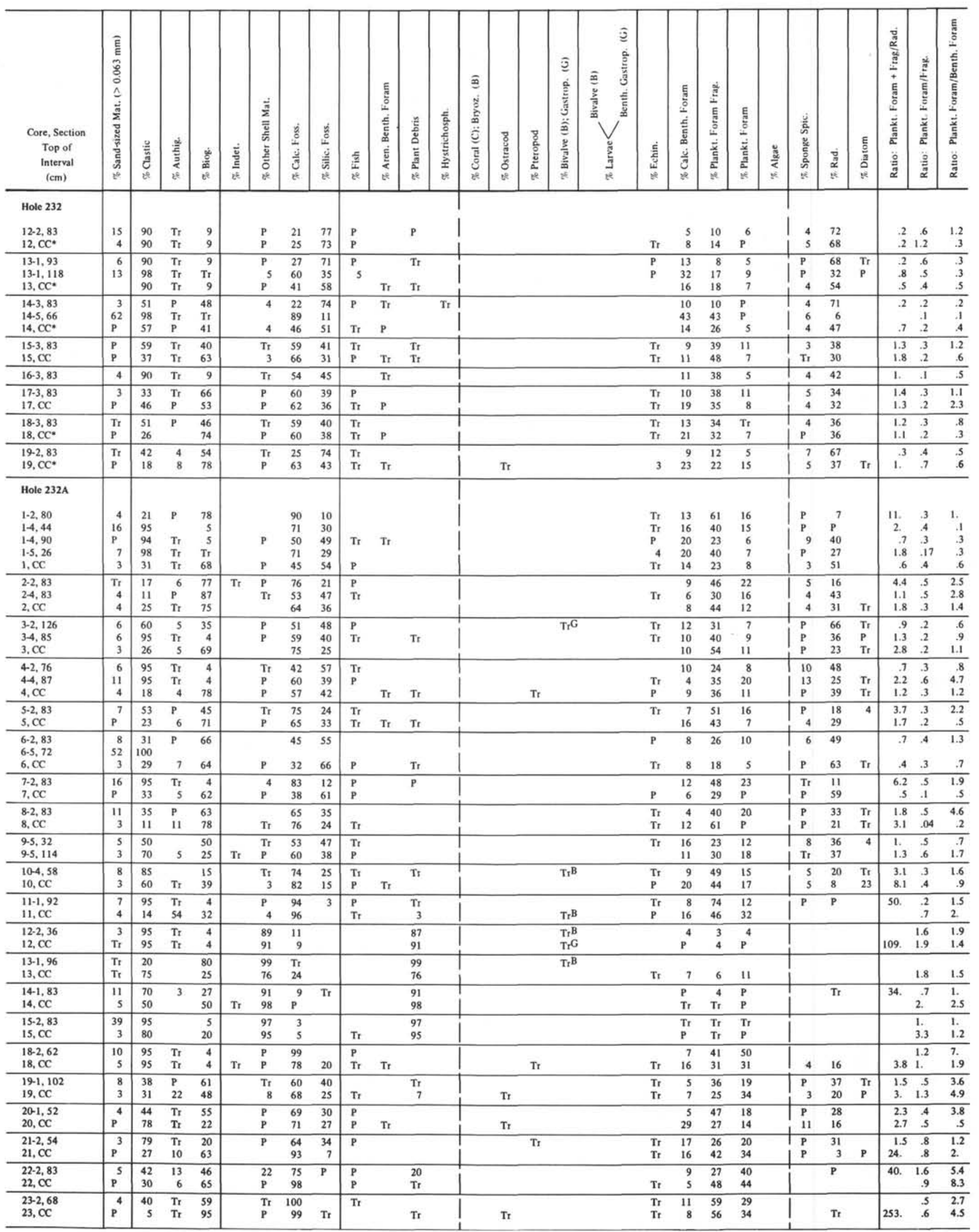




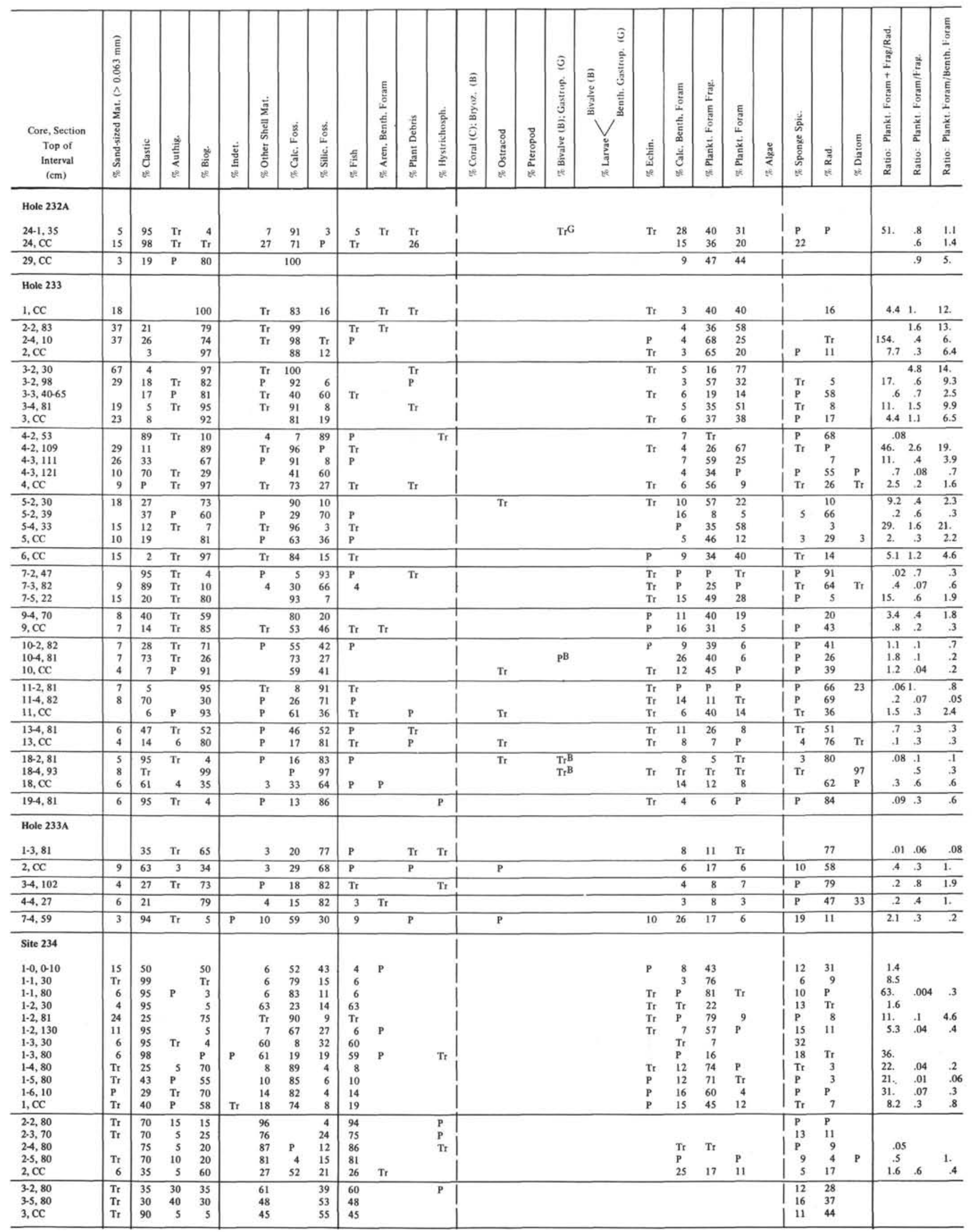




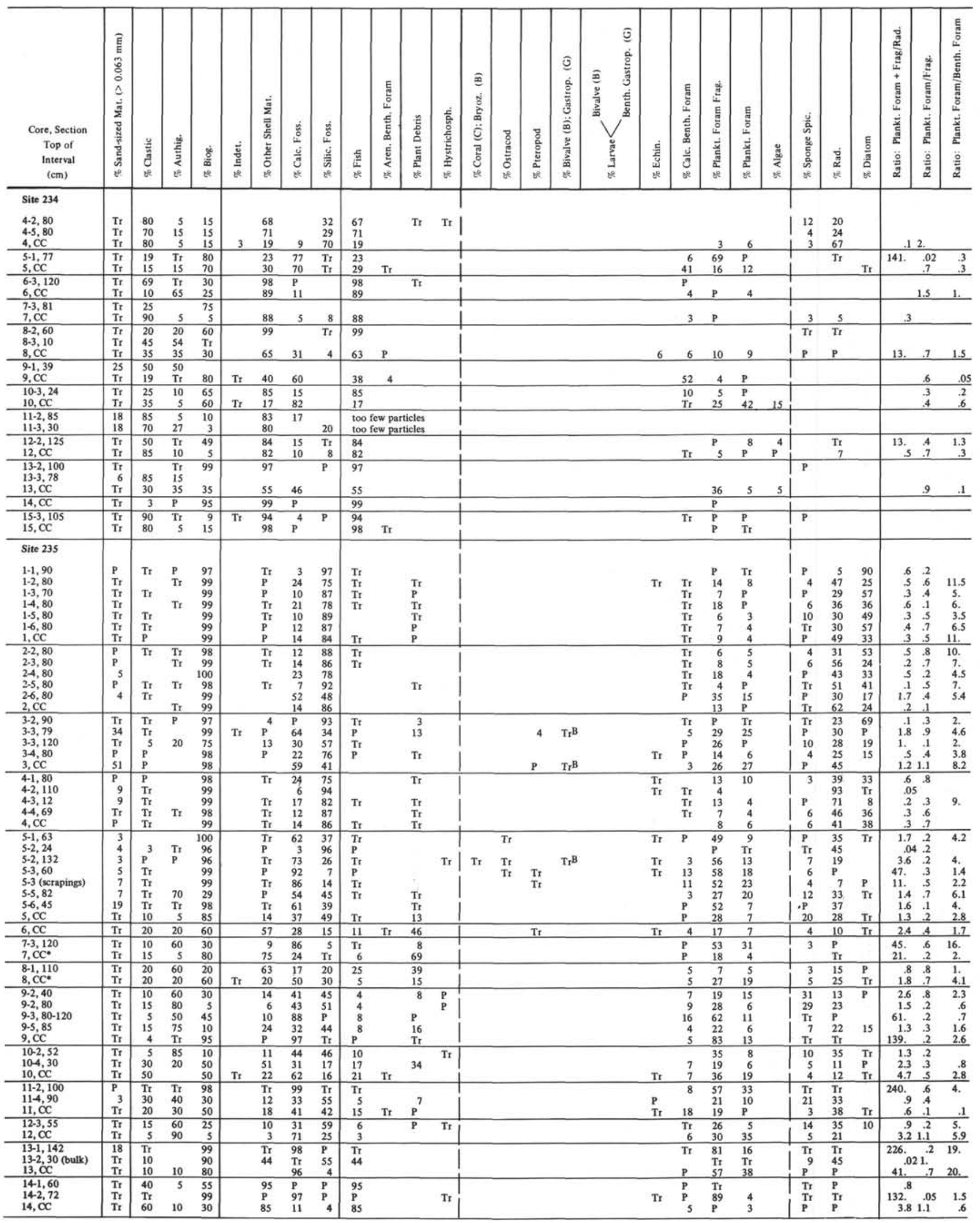




\begin{tabular}{|c|c|c|c|c|c|c|c|c|c|c|c|c|c|c|c|c|c|c|c|c|c|c|c|c|c|c|c|c|}
\hline $\begin{array}{c}\text { Core, Section } \\
\text { Top of } \\
\text { Interval } \\
\text { (cm) }\end{array}$ & 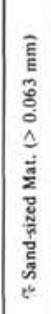 & 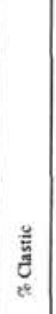 & 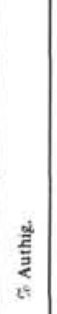 & 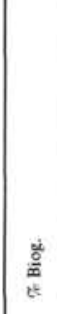 & 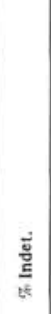 & 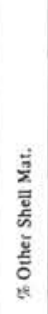 & 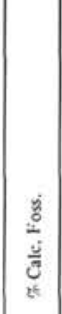 & 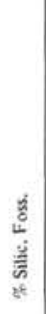 & 竞 & 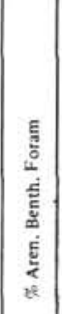 & 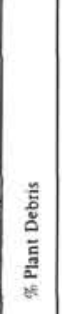 & 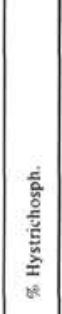 & 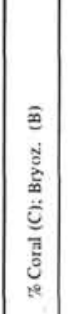 & 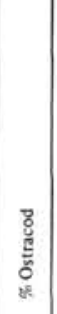 & 总 & 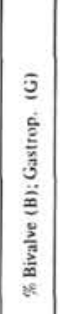 & 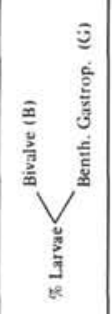 & 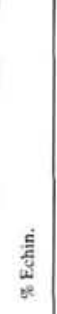 & 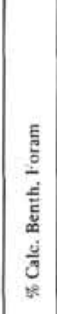 & 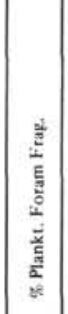 & 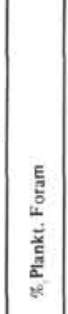 & $\begin{array}{l}\frac{0}{2} \\
\frac{3}{2} \\
2\end{array}$ & 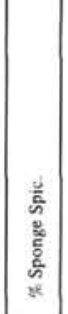 & 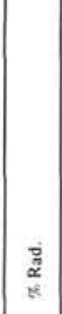 & 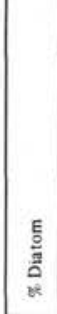 & 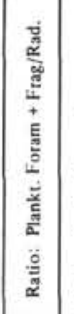 & 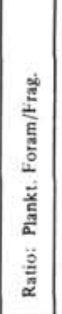 & 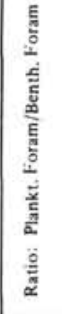 \\
\hline Site 235 & & & & & & & & & & & & & & & & & & & & & & & & & & & & \\
\hline $15, \mathrm{CC}$ & $\mathrm{T}_{\mathrm{t}}$ & 60 & $\mathrm{Tr}$ & 39 & & 13 & 47 & 40 & 11 & & $P$ & & & & $\mathrm{Tr}$ & & & & 4 & 22 & 21 & & 8 & 32 & & 1.3 & 1. & 6. \\
\hline $16-1,120$ & $T_{t}$ & 70 & 25 & 5 & & 55 & 6 & 38 & 55 & & & & & & & & & & & 5 & $P$ & & 4 & 34 & & .2 & .2 & \\
\hline $\begin{array}{l}\text { Site } 236 \\
\\
1-1,104 \\
1-2,10 \\
1-2,75 \\
1 \cdot 3,39 \\
1-4,6 \\
1, \text { CC }\end{array}$ & $\begin{array}{l}6 \\
9 \\
7 \\
6 \\
5 \\
4\end{array}$ & & & $\begin{array}{l}100 \\
100 \\
100 \\
100 \\
100 \\
100\end{array}$ & & $\begin{array}{l}T_{r} \\
T_{r} \\
T_{r}\end{array}$ & $\begin{array}{r}42 \\
31 \\
9 \\
10 \\
3 \\
21\end{array}$ & $\begin{array}{l}59 \\
68 \\
91 \\
90 \\
96 \\
79\end{array}$ & $\begin{array}{l}\mathrm{Tr} \\
\mathrm{Tr} \\
\mathrm{Tr}\end{array}$ & $\mathrm{T}_{t}$ & & & & & 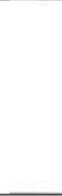 & & & $\mathrm{Tr}$ & $\begin{array}{l}\mathrm{Tr} \\
\mathrm{Tr} \\
\mathrm{Tr} \\
\mathrm{Tr} \\
\mathrm{Tr}\end{array}$ & $\begin{array}{r}38 \\
26 \\
5 \\
6 \\
\mathrm{P} \\
17 \\
\end{array}$ & $\begin{array}{c}4 \\
5 \\
3 \\
3 \\
3 \\
\mathrm{Tr} \\
\mathrm{P}\end{array}$ & & $\begin{array}{l}\mathrm{Tr} \\
\mathrm{P} \\
\mathrm{P} \\
5 \\
\mathrm{P} \\
\mathrm{P} \\
\mathrm{P}\end{array}$ & $\begin{array}{l}43 \\
53 \\
85 \\
80 \\
91 \\
77 \\
\end{array}$ & $\begin{array}{r}15 \\
14 \\
5 \\
5 \\
4\end{array}$ & $\begin{array}{l}1 . \\
.6 \\
.1 \\
.1 \\
.03 \\
.3\end{array}$ & $\begin{array}{l}.1 \\
.2 \\
.6 \\
.5 \\
.2 \\
.2\end{array}$ & $\begin{array}{l}6 . \\
7 . \\
5 . \\
1 . \\
4 .\end{array}$ \\
\hline $\begin{array}{l}2-1,70 \\
2 \cdot 1,148 \\
2, \mathrm{CC}\end{array}$ & $\begin{array}{l}7 \\
9 \\
9\end{array}$ & & & $\begin{array}{l}100 \\
100 \\
100\end{array}$ & & $\begin{array}{l}\mathrm{p} \\
\mathrm{T} t\end{array}$ & $\begin{array}{l}38 \\
87 \\
89\end{array}$ & $\begin{array}{l}62 \\
12 \\
11\end{array}$ & $\begin{array}{l}\mathrm{P} \\
\mathrm{T}\end{array}$ & & & & & $\mathrm{Tr}$ & & & & $\begin{array}{l}\mathrm{Tr} \\
\mathrm{Tr}\end{array}$ & $\begin{array}{l}\mathrm{Tr} \\
\mathrm{P} \\
\mathrm{P}\end{array}$ & $\begin{array}{l}32 \\
78 \\
62\end{array}$ & $\begin{array}{r}6 \\
6 \\
25\end{array}$ & & $\begin{array}{l}3 \\
\mathrm{Tr} \\
\mathrm{Tr}\end{array}$ & $\begin{array}{l}54 \\
11 \\
10\end{array}$ & 4 & $\begin{array}{l}.7 \\
7.8 \\
8.5\end{array}$ & $\begin{array}{l}.2 \\
.1 \\
.4\end{array}$ & $\begin{array}{c}19 . \\
2.6 \\
18 .\end{array}$ \\
\hline $\begin{array}{l}3-1,36 \\
3-1,78 \\
3-2,55 \\
3-2,66 \\
3-2,78 \\
3-2,100 \\
3-2,118 \\
3-3,11 \\
3, \mathrm{CC} \\
\end{array}$ & \begin{tabular}{|l|}
10 \\
66 \\
81 \\
81 \\
11 \\
11 \\
11 \\
11 \\
\end{tabular} & $\begin{array}{l}\mathrm{T} t \\
\mathrm{~T}_{t}\end{array}$ & $\begin{array}{l}\mathrm{P} \\
\mathrm{P}\end{array}$ & $\begin{array}{r}100 \\
100 \\
98 \\
100 \\
99 \\
100 \\
100 \\
100 \\
100 \\
\end{array}$ & $\mathrm{Tr}_{\mathrm{r}}$ & $\begin{array}{l}\mathrm{Tr} \\
\mathrm{Tr} \\
\\
\mathrm{Tr} \\
\mathrm{Pr} \\
\mathrm{Tr} \\
\mathrm{Tr}\end{array}$ & $\begin{array}{r}64 \\
100 \\
99 \\
99 \\
100 \\
100 \\
98 \\
100 \\
98 \\
\end{array}$ & $\begin{array}{l}35 \\
\mathrm{Tr} \\
\mathrm{Tr} \\
\mathrm{Tr} \\
\mathrm{Tr} \\
\mathrm{P} \\
\mathrm{P}\end{array}$ & $\begin{array}{l}\mathrm{Tr} \\
\mathrm{Tr} \\
\\
\mathrm{Tr} \\
\mathrm{P} \\
\mathrm{Tr} \\
\mathrm{Tr}\end{array}$ & & & & $\mathrm{Tr}_{\mathrm{r}} \mathrm{C}$ & $\begin{array}{l}\mathrm{Tr} \\
\mathrm{Tr}\end{array}$ & 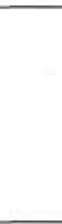 & & & $\begin{array}{l}\mathrm{Tr} \\
\mathrm{Tr} \\
\mathrm{Tr} \\
\mathrm{Tr}\end{array}$ & $\begin{array}{c}\mathrm{Tr} \\
\mathrm{Tr} \\
4 \\
\mathrm{P} \\
\mathrm{P} \\
\mathrm{Tr} \\
\mathrm{P} \\
\mathrm{P} \\
\mathrm{P}\end{array}$ & $\begin{array}{l}51 \\
64 \\
56 \\
32 \\
44 \\
49 \\
91 \\
73 \\
66 \\
\end{array}$ & $\begin{array}{r}12 \\
36 \\
38 \\
63 \\
52 \\
50 \\
6 \\
23 \\
29 \\
29\end{array}$ & & $\begin{array}{l}\mathrm{P} \\
\mathrm{Tr} \\
\mathrm{Tt}\end{array}$ & $\begin{array}{l}\mathrm{Tr} \\
\mathrm{Tr}\end{array}$ & $\mathrm{Tr}$ & $\begin{array}{r}226 . \\
264 . \\
\\
125 . \\
78 .\end{array}$ & $\begin{array}{l}.2 \\
.6 \\
.7 \\
2 . \\
1.2 \\
1 . \\
.06 \\
.3 \\
.4 \\
\end{array}$ & $\begin{array}{c}32 . \\
94 . \\
9.1 \\
21 . \\
18 . \\
120 . \\
3.3 \\
15 . \\
12 . \\
\end{array}$ \\
\hline $\begin{array}{l}4-1,65 \\
4-2,113 \\
4-3,33 \\
4-4,70 \\
4-4,113 \\
4-5,101 \\
4, \mathrm{CC}\end{array}$ & \begin{tabular}{|l|}
30 \\
11 \\
57 \\
33 \\
$\mathrm{P}$ \\
$\mathrm{P}$ \\
$\mathrm{S}$ \\
\end{tabular} & $\begin{array}{l}\mathrm{Tr} \\
\mathrm{Tr} \\
\mathrm{Tr} \\
\mathrm{Tr} \\
\mathrm{P}\end{array}$ & $\mathrm{Tr}$ & $\begin{array}{r}99 \\
100 \\
100 \\
100 \\
100 \\
99 \\
100 \\
\end{array}$ & $\mathrm{Tr}$ & $\begin{array}{l}\mathrm{Tr} \\
\mathrm{Tr} \\
\mathrm{P} \\
5 \\
\mathrm{Tr}\end{array}$ & $\begin{array}{r}97 \\
99 \\
100 \\
100 \\
98 \\
95 \\
99 \\
\end{array}$ & $\begin{array}{l}\mathrm{P} \\
\mathrm{Tr} \\
\mathrm{Tr} \\
\mathrm{Tr} \\
\mathrm{Tr} \\
\end{array}$ & $\begin{array}{l}\mathrm{Tr} \\
\mathrm{Tr} \\
\mathrm{P} \\
{ }_{5} \\
\mathrm{Tr}\end{array}$ & $\mathrm{Tt}$ & & & & $\mathrm{Tr}$ & & & & $\begin{array}{l}\mathrm{P} \\
\mathrm{Tr} \\
\mathrm{Tr}\end{array}$ & $\begin{array}{r}6 \\
3 \\
\mathrm{Tr}^{2} \\
7 \\
4 \\
6 \\
8 \\
\end{array}$ & $\begin{array}{l}53 \\
76 \\
43 \\
62 \\
64 \\
75 \\
49 \\
\end{array}$ & $\begin{array}{l}37 \\
20 \\
56 \\
30 \\
30 \\
15 \\
42 \\
\end{array}$ & & $\begin{array}{l}\mathrm{P} \\
\mathrm{Tr} \\
\mathrm{Tr} \\
\mathrm{Tr}\end{array}$ & $\begin{array}{l}\mathrm{Tr} \\
\mathrm{Tr}\end{array}$ & & \begin{tabular}{|l}
252. \\
211.
\end{tabular} & $\begin{array}{r}.7 \\
.3 \\
1.3 \\
.5 \\
.5 \\
.2 \\
.9 \\
\end{array}$ & $\begin{array}{c}6.2 \\
6 . \\
94 . \\
4.1 \\
7.3 \\
2.5 \\
5.4 \\
\end{array}$ \\
\hline $\begin{array}{l}5-1,93 \\
5-1,125 \\
5-2,11 \\
5-3,89 \\
5-3,118 \\
5-4,62 \\
5-6,80 \\
5, C C\end{array}$ & \begin{tabular}{|c|}
89 \\
$\mathrm{Tt}$ \\
3 \\
86 \\
$\mathrm{Tr}$ \\
46 \\
\end{tabular} & $\begin{array}{c}4 \\
\mathrm{~T} r \\
\mathrm{Tr} \\
\mathrm{Tr} \\
5 \\
\mathrm{P} \\
\mathrm{Tr} \\
\mathrm{Tr}\end{array}$ & & $\begin{array}{r}96 \\
99 \\
100 \\
99 \\
95 \\
98 \\
100 \\
100 \\
\end{array}$ & Tr & $\begin{array}{c}\mathrm{Tr} \\
5 \\
4 \\
\mathrm{Tr} \\
16 \\
\mathrm{Tr} \\
\mathrm{Tr} \\
\mathrm{Tr}\end{array}$ & $\begin{array}{r}99 \\
95 \\
96 \\
100 \\
84 \\
100 \\
99 \\
99\end{array}$ & $\begin{array}{ll}\mathrm{Tr} \\
\mathrm{Tr}\end{array}$ & $\begin{array}{c}\mathrm{Tr} \\
5 \\
4 \\
4 \\
16 \\
\mathrm{Tr} \\
\mathrm{Tr} \\
\mathrm{Tr}\end{array}$ & $\mathrm{Tr}_{\mathrm{r}}$ & & & $\mathrm{Tr}^{\mathrm{B}}$ & $\begin{array}{l}\mathrm{Tr} \\
\mathrm{Tr} \\
\mathrm{Tr}\end{array}$ & $\mathrm{Tr}$ & & & $\begin{array}{l}\mathrm{Tr} \\
\mathrm{Tr} \\
\mathrm{Tr} \\
\mathrm{Tr} \\
\mathrm{Tr} \\
\mathrm{Tr} \\
\mathrm{Tr} \\
\mathrm{Tr}\end{array}$ & $\begin{array}{l}{ }^{5} \\
\mathrm{P}^{7} \\
\mathrm{P}^{3} \\
\mathrm{P}^{5} \\
\mathrm{P}^{2} \\
\mathrm{P}\end{array}$ & \begin{tabular}{|l|}
18 \\
74 \\
91 \\
5 \\
68 \\
30 \\
36 \\
16 \\
16
\end{tabular} & $\begin{array}{l}74 \\
14 \\
\mathrm{P} \\
89 \\
9 \\
64 \\
64 \\
50 \\
80\end{array}$ & $\mathrm{Tr}$ & Tr & $\mathrm{Tr}$ & & $\begin{array}{r}183 . \\
15 \\
\\
\\
\\
\end{array}$ & $\begin{array}{l}. \\
.2 \\
.03 \\
19 . \\
.1 \\
2.2 \\
1.6 \\
4.9\end{array}$ & $\begin{array}{c}16 . \\
2 . \\
11.5 \\
27 . \\
4 . \\
12 . \\
26 . \\
37 . \\
\end{array}$ \\
\hline $\begin{array}{l}6-1,18 \\
6-1,106 \\
6-2,38 \\
6-3,74 \\
6-3,134 \\
6-4,68 \\
6-5,40 \\
6, C c\end{array}$ & \begin{tabular}{|c}
11 \\
68 \\
13 \\
3 \\
62 \\
72 \\
78 \\
4 \\
\end{tabular} & $\begin{array}{l}\mathrm{Tr} \\
\mathrm{Tr}\end{array}$ & $\begin{array}{l}7 \\
{ }^{\mathrm{P}} \\
\mathrm{Tr}\end{array}$ & $\begin{array}{r}100 \\
100 \\
100 \\
93 \\
100 \\
99 \\
99 \\
100 \\
\end{array}$ & $T_{r}$ & $\begin{array}{l}\mathrm{P} \\
\mathrm{Tr} \\
48 \\
\mathrm{Tr} \\
\mathrm{P}\end{array}$ & $\begin{array}{r}99 \\
100 \\
99 \\
52 \\
100 \\
99 \\
100 \\
98 \\
\end{array}$ & $\begin{array}{l}\mathrm{Tr} \\
\mathrm{Tr} \\
\mathrm{Tr}\end{array}$ & $\begin{array}{l}\mathrm{P} \\
\mathrm{Tt} \\
48 \\
\mathrm{Tt} \\
\mathrm{P}\end{array}$ & & & & $\mathrm{T}_{r} \mathrm{~B}$ & $\begin{array}{l}\text { Tr } \\
\text { Tr } \\
\text { Tr }\end{array}$ & & & & $\begin{array}{l}\mathrm{P} \\
\mathrm{P} \\
\mathrm{Tr} \\
\mathrm{Tr}\end{array}$ & 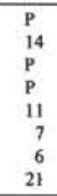 & $\begin{array}{l}82 \\
45 \\
83 \\
43 \\
38 \\
36 \\
21 \\
36\end{array}$ & $\begin{array}{r}14 \\
39 \\
14 \\
7 \\
49 \\
54 \\
73 \\
41\end{array}$ & & $\mathrm{Tr}$ & $\begin{array}{l}\mathrm{Tr} \\
\mathrm{Tr}\end{array}$ & & $\begin{array}{l}260 . \\
213 .\end{array}$ & $\begin{array}{l}.2 \\
.9 \\
.2 \\
.2 \\
1.3 \\
1.5 \\
3.5 \\
1.1 \\
\end{array}$ & $\begin{array}{c}7.6 \\
2.8 \\
6.4 \\
2.4 \\
4.7 \\
7.3 \\
12 . \\
1.9 \\
\end{array}$ \\
\hline $\begin{array}{l}7-1,68 \\
7-2,70 \\
7-3,58 \\
7-4,80 \\
7-5,35 \\
7-5,98 \\
7-6,39 \\
7, \mathrm{CC}\end{array}$ & \begin{tabular}{|r}
3 \\
22 \\
77 \\
54 \\
$\mathrm{Tr}$ \\
62 \\
58 \\
14 \\
\end{tabular} & $\begin{array}{c}\mathrm{Tr} \\
\\
\mathrm{Tr} \\
5 \\
\mathrm{Tr}\end{array}$ & $\begin{array}{l}\mathrm{Tr} \\
\mathrm{P} \\
\mathrm{Tr} \\
\mathrm{Tr} \\
\mathrm{Tr} \\
\mathrm{Tr} \\
\end{array}$ & $\begin{array}{r}98 \\
100 \\
99 \\
99 \\
94 \\
99 \\
100 \\
99 \\
9\end{array}$ & & $\begin{array}{c}4 \\
\mathrm{Tr} \\
\mathrm{Tr} \\
\mathrm{Tr} \\
6 \\
\mathrm{Tr} \\
\mathrm{Tr} \\
\mathrm{Tr} \\
\mathrm{Tr}\end{array}$ & $\begin{array}{l}96 \\
99 \\
99 \\
98 \\
93 \\
99 \\
97 \\
99 \\
\end{array}$ & $\begin{array}{l}\mathrm{Tr} \\
\mathrm{P} \\
\mathrm{Tr} \\
\mathrm{P} \\
\mathrm{Tr} \\
\mathrm{Tr} \\
\mathrm{P}\end{array}$ & $\begin{array}{c}3 \\
\mathrm{Tr}_{\mathrm{t}} \\
\mathrm{Tr} \\
\mathrm{Tr} \\
6 \\
\mathrm{Tr} \\
\mathrm{Tr} \\
\mathrm{Tt} \\
\mathrm{Tt}\end{array}$ & $T_{r}$ & & & & $\begin{array}{l}T_{t} \\
T_{t}\end{array}$ & & & & $\begin{array}{l}\mathrm{Tr} \\
\mathrm{Tr} \\
\mathrm{Tr} \\
\mathrm{P} \\
\mathrm{Pr} \\
\mathrm{Tr} \\
\mathrm{P} \\
\mathrm{P} \\
\end{array}$ & $\begin{array}{c}4 \\
\mathrm{P}^{4} \\
8 \\
8 \\
5 \\
9 \\
\mathrm{P} \\
9 \\
9\end{array}$ & $\begin{array}{l}83 \\
62 \\
46 \\
69 \\
80 \\
42 \\
29 \\
54 \\
\end{array}$ & $\begin{array}{r}8 \\
33 \\
45 \\
19 \\
8 \\
47 \\
64 \\
35 \\
\end{array}$ & & $\begin{array}{l}\mathrm{P} \\
\mathrm{Tr} \\
\mathrm{P} \\
\mathrm{Tr} \\
\mathrm{P}\end{array}$ & $\begin{array}{l}\mathrm{Tr} \\
\mathrm{Tr}\end{array}$ & & $\begin{array}{r}98 . \\
238 .\end{array}$ & $\begin{array}{r}.1 \\
.5 \\
1 . \\
.3 \\
.1 \\
1.1 \\
2.1 \\
.7 \\
\end{array}$ & $\begin{array}{c}1.9 \\
13 . \\
5.7 \\
2.4 \\
1.5 \\
5 . \\
23 . \\
3.9 \\
\end{array}$ \\
\hline $\begin{array}{l}8-1,85 \\
8-2,114 \\
8-3,22 \\
8-3,74 \\
8-4,43 \\
8-4,106 \\
8-5,146 \\
8-6,66 \\
8, C C\end{array}$ & \begin{tabular}{|c|}
61 \\
20 \\
45 \\
Tr \\
50 \\
59 \\
36 \\
10 \\
9 \\
\end{tabular} & $\begin{array}{l}\mathrm{Tr} \\
\mathrm{Tt} \\
\mathrm{Tr}\end{array}$ & $\begin{array}{l}\mathrm{Tr} \\
\mathrm{Tr}\end{array}$ & $\begin{array}{r}100 \\
100 \\
100 \\
99 \\
99 \\
100 \\
100 \\
100 \\
99\end{array}$ & & $\begin{array}{l}7 \\
\mathrm{Tr} \\
\mathrm{Tr} \\
\mathrm{P} \\
\mathrm{P}\end{array}$ & $\begin{array}{r}97 \\
100 \\
95 \\
91 \\
98 \\
97 \\
87 \\
98 \\
100 \\
\end{array}$ & $\begin{array}{l}\mathrm{P} \\
\mathrm{Tr} \\
5 \\
\mathrm{P} \\
\mathrm{P} \\
\mathrm{P} \\
12 \\
\mathrm{Tr} \\
\mathrm{Tr}\end{array}$ & $\begin{array}{l}7 \\
T_{t} \\
\text { Trt } \\
\text { Trt } \\
\text { P }\end{array}$ & & $\begin{array}{l}\mathrm{Tr} \\
\mathrm{Tr}\end{array}$ & & & $\begin{array}{l}\mathrm{Tr} \\
\mathrm{Tr} \\
\mathrm{Tr}\end{array}$ & & & & $\begin{array}{l}\mathrm{Tr} \\
\mathrm{Tr} \\
\mathrm{Tr} \\
\mathrm{Tr} \\
\mathrm{Tr} \\
\mathrm{Tr} \\
\mathrm{Tr}\end{array}$ & $\begin{array}{c}\mathrm{P} \\
8 \\
8 \\
4 \\
47 \\
17 \\
\mathrm{P} \\
\mathrm{P} \\
10 \\
4 \\
4\end{array}$ & $\begin{array}{l}49 \\
53 \\
39 \\
82 \\
38 \\
41 \\
56 \\
42 \\
52 \\
\end{array}$ & $\begin{array}{l}49 \\
38 \\
46 \\
4 \\
41 \\
53 \\
29 \\
40 \\
43 \\
\end{array}$ & & $\begin{array}{l}\mathrm{P} \\
\mathrm{Tr} \\
\mathrm{S} \\
\mathrm{P} \\
\mathrm{P} \\
\mathrm{P} \\
\mathrm{P} \\
\mathrm{Tr} \\
\mathrm{Tr}\end{array}$ & $\begin{array}{c}\mathrm{Tr} \\
\mathrm{Tr} \\
6\end{array}$ & 4 & $\begin{array}{r}216 . \\
23 . \\
14 .\end{array}$ & $\begin{array}{l}1 . \\
.7 \\
1.2 \\
.05 \\
1.1 \\
1.3 \\
.5 \\
.9 \\
.8 \\
\end{array}$ & $\begin{array}{c}30 . \\
4.9 \\
5.6 \\
.9 \\
2.4 \\
21 . \\
21 . \\
3.8 \\
12 . \\
\end{array}$ \\
\hline $\begin{array}{l}9-1,118 \\
9-2,121 \\
9-3,124 \\
9-4,84 \\
9-5,30\end{array}$ & \begin{tabular}{|r|}
6 \\
42 \\
62 \\
65 \\
3 \\
\end{tabular} & $\begin{array}{l}\mathrm{T}_{\mathrm{r}} \\
\mathrm{P}\end{array}$ & $\mathrm{P}^{4}$ & $\begin{array}{r}100 \\
100 \\
100 \\
96 \\
97\end{array}$ & & $\begin{array}{l}\mathrm{Tr} \\
\mathrm{Tr} \\
22\end{array}$ & $\begin{array}{l}97 \\
97 \\
94 \\
98 \\
26\end{array}$ & \begin{tabular}{|l|}
$\mathrm{P}$ \\
3 \\
5 \\
$\mathrm{P}$ \\
52 \\
\end{tabular} & $\begin{array}{l}\mathrm{Tr} \\
\mathrm{Tr} \\
22\end{array}$ & & $\mathrm{Tt}$ & & & $\begin{array}{l}\text { Trt } \\
\text { Tr }\end{array}$ & & & & $\begin{array}{l}\mathrm{Tr} \\
\mathrm{Tr} \\
\mathrm{Tr}\end{array}$ & $\begin{array}{r}6 \\
11 \\
7 \\
5 \\
9 \\
\end{array}$ & $\begin{array}{l}57 \\
54 \\
50 \\
46 \\
13\end{array}$ & $\begin{array}{r}34 \\
35 \\
36 \\
45 \\
4 \\
\end{array}$ & & $\begin{array}{l}\mathrm{P} \\
3 \\
4 \\
\mathrm{P} \\
43 \\
\end{array}$ & $\begin{array}{c}\mathrm{Tr} \\
\mathrm{Tr} \\
9 \\
9\end{array}$ & & \begin{tabular}{|c|}
83. \\
186. \\
\end{tabular} & $\begin{array}{l}.6 \\
.7 \\
.7 \\
1.3 \\
.3\end{array}$ & $\begin{array}{l}5.5 \\
5.6 \\
5.4 \\
9.2 \\
.5 \\
\end{array}$ \\
\hline $\begin{array}{l}10-2,113 \\
10-3,94 \\
10-4,7 \\
10-5,77 \\
10,0 \mathrm{C}\end{array}$ & \begin{tabular}{|r}
3 \\
4 \\
100 \\
$\mathrm{Tr}$
\end{tabular} & $\mathrm{Tr}$ & $\mathrm{Tr}$ & $\begin{array}{r}100 \\
100 \\
100 \\
100 \\
99 \\
\end{array}$ & & $\begin{array}{l}\mathrm{Tr} \\
\mathrm{P} \\
\mathrm{Tr} \\
5 \\
\mathrm{Tr}\end{array}$ & $\begin{array}{l}92 \\
94 \\
98 \\
70 \\
94 \\
\end{array}$ & \begin{tabular}{|c|}
7 \\
5 \\
$P^{2}$ \\
25 \\
5 \\
\end{tabular} & $\begin{array}{c}\mathrm{Tr} \\
\mathrm{P} \\
\mathrm{Tr} \\
\mathrm{S} \\
\mathrm{Tr} \\
\end{array}$ & $\mathrm{Tr}$ & & & & $\mathrm{Tr}_{\mathrm{r}}$ & & & & $\mathrm{Tr}$ & $\begin{array}{r}6 \\
6 \\
7 \\
4 \\
11 \\
\end{array}$ & $\begin{array}{l}45 \\
59 \\
44 \\
62 \\
31 \\
\end{array}$ & $\begin{array}{r}41 \\
28 \\
47 \\
3 \\
33 \\
53\end{array}$ & & $\begin{array}{l}\mathrm{S} \\
\mathrm{P} \\
\mathrm{P} \\
14 \\
4 \\
\end{array}$ & $\begin{array}{l}{ }^{3} \\
\mathrm{P}^{2} \\
\mathrm{Tr} \\
12 \\
\mathrm{P}\end{array}$ & & \begin{tabular}{|c|}
29. \\
54. \\
167. \\
5.6 \\
57. \\
\end{tabular} & $\begin{array}{c}.9 \\
.5 \\
1.1 \\
.05 \\
1.7 \\
\end{array}$ & $\begin{array}{l}7.3 \\
4.7 \\
6.6 \\
.8 \\
5 . \\
\end{array}$ \\
\hline $\begin{array}{l}11-1,65 \\
11-1,125 \\
11-2,88 \\
11, C C\end{array}$ & \begin{tabular}{|c|}
3 \\
11 \\
$\mathrm{P}$ \\
$\mathrm{Tr}$
\end{tabular} & $T_{r}$ & $\begin{array}{l}\mathrm{Tr} \\
\mathrm{P} \\
\mathrm{Tr} \\
\mathrm{P}\end{array}$ & $\begin{array}{r}100 \\
99 \\
99 \\
98\end{array}$ & & $\begin{array}{c}\mathrm{Tr} \\
\mathrm{Ti} \\
4 \\
\mathrm{P}\end{array}$ & $\begin{array}{l}92 \\
94 \\
65 \\
85\end{array}$ & $\begin{array}{r}7 \\
4 \\
31 \\
14\end{array}$ & $\begin{array}{l}\mathrm{Tr} \\
\mathrm{Tr} \\
4 \\
\mathrm{P}\end{array}$ & & & & & & & & & $\begin{array}{l}\mathrm{Tr} \\
\mathrm{Tr} \\
\mathrm{Tr}\end{array}$ & $\begin{array}{r}10 \\
4 \\
5 \\
8\end{array}$ & $\begin{array}{l}48 \\
70 \\
44 \\
15\end{array}$ & $\begin{array}{l}33 \\
22 \\
16 \\
61\end{array}$ & & $\begin{array}{l}6 \\
4 \\
7 \\
5\end{array}$ & $\begin{array}{l}\text { P } \\
24 \\
9\end{array}$ & & \begin{tabular}{c|}
68. \\
2.5 \\
8.8
\end{tabular} & $\begin{array}{r}.7 \\
.3 \\
.4 \\
4.1\end{array}$ & $\begin{array}{l}3.2 \\
5.6 \\
3.5 \\
7.4\end{array}$ \\
\hline
\end{tabular}




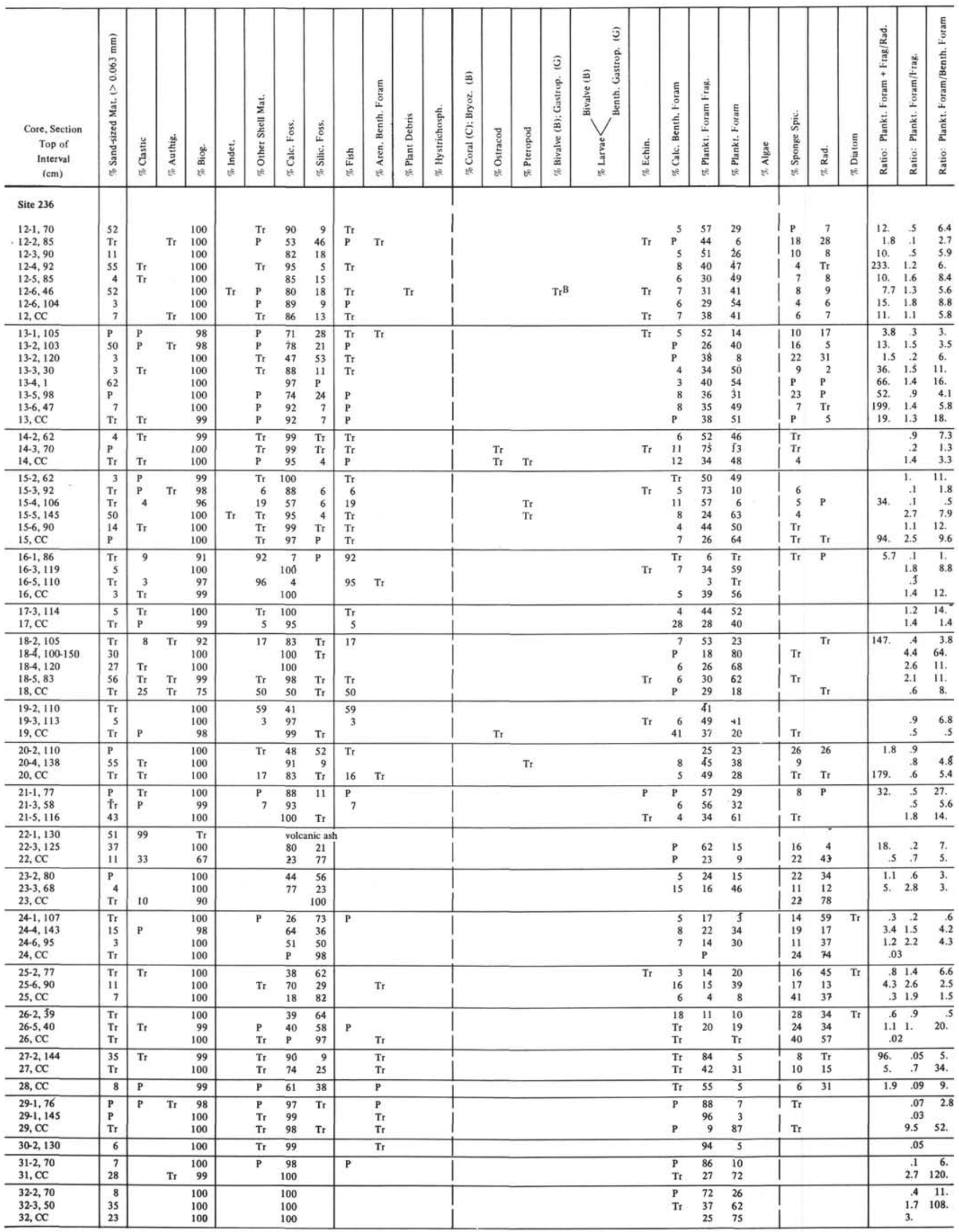




\begin{tabular}{|c|c|c|c|c|c|c|c|c|c|c|c|c|c|c|c|c|c|c|c|c|c|c|c|c|c|c|c|c|}
\hline $\begin{array}{c}\text { Core, Section } \\
\text { Top of } \\
\text { Interval } \\
\text { (cm) }\end{array}$ & 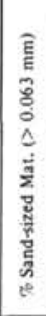 & 起 & 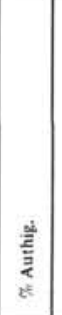 & 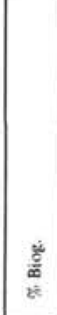 & $\frac{\bar{u}}{\frac{u}{\varepsilon}}$ & 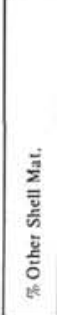 & 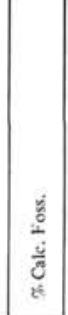 & 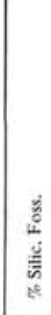 & $\frac{5}{2}$ & 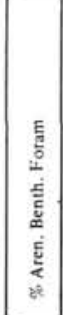 & 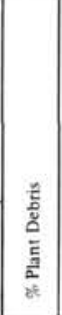 & 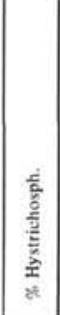 & 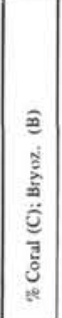 & 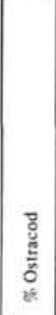 & 总 & 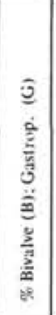 & 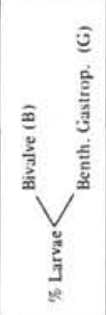 & 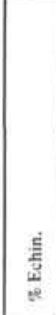 & 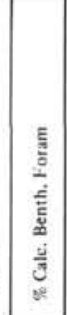 & 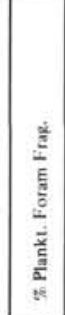 & 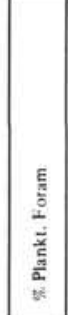 & $\frac{\underline{u}}{\frac{2}{2}}$ & 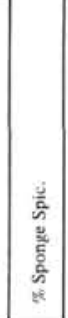 & 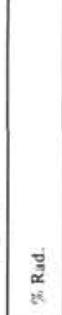 & 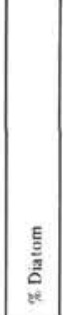 & 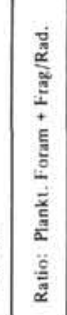 & 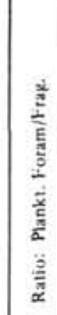 & 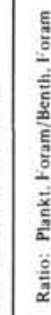 \\
\hline $\begin{array}{l}\text { Site } 236 \\
33-2,23 \\
33-3.40 \\
33-3,107\end{array}$ & $\begin{array}{l}42 \\
36 \\
33\end{array}$ & Tr & $\begin{array}{l}\mathrm{T}_{\mathrm{r}} \\
\mathrm{T}_{\mathrm{r}}\end{array}$ & $\begin{array}{r}99 \\
100 \\
99\end{array}$ & & $T_{t}$ & $\begin{array}{r}100 \\
100 \\
99\end{array}$ & $\mathrm{Tr}$ & Tr & & & & & & $\mathrm{Tr}_{\mathrm{r}}$ & & & & $\begin{array}{l}\mathrm{Tr} \\
\mathrm{Tr} \\
\mathrm{Tr}\end{array}$ & $\begin{array}{l}10 \\
13 \\
56\end{array}$ & $\begin{array}{l}89 \\
86 \\
42\end{array}$ & & $\mathrm{Tr}$ & & & & $\begin{array}{r}9.3 \\
6.7 \\
.8\end{array}$ & $\begin{array}{r}93 . \\
200 . \\
54 .\end{array}$ \\
\hline $\begin{array}{l}\text { Site 237 } \\
1-1,73 \\
1-2,85 \\
1-3,65 \\
1-4,85 \\
1, C C\end{array}$ & \begin{tabular}{|l|}
80 \\
78 \\
84 \\
79 \\
56 \\
\end{tabular} & & & $\begin{array}{l}100 \\
100 \\
100 \\
100 \\
100\end{array}$ & & & $\begin{array}{l}100 \\
100 \\
100 \\
100 \\
100\end{array}$ & & & & & & & $\mathrm{Tr}$ & & & & $\begin{array}{l}\mathrm{Tr} \\
\mathrm{Tr} \\
\mathrm{Tr} \\
\mathrm{Tr} \\
\mathrm{Tr}\end{array}$ & $\begin{array}{l}\mathrm{Tr} \\
\mathrm{Tr}\end{array}$ & $\begin{array}{l}9 \\
50 \\
58 \\
62 \\
40\end{array}$ & $\begin{array}{l}91 \\
50 \\
42 \\
38 \\
59\end{array}$ & & & & & & $\begin{array}{r}10 . \\
1 . \\
.7 \\
.6 \\
1.5\end{array}$ & $\begin{array}{r}85 . \\
147 .\end{array}$ \\
\hline $\begin{array}{l}2-1,85 \\
2-2,85 \\
2, \mathrm{CC}\end{array}$ & \begin{tabular}{|l|}
92 \\
94 \\
85 \\
\end{tabular} & & & $\begin{array}{l}100 \\
100 \\
100 \\
\end{array}$ & & $\mathrm{Tr}$ & $\begin{array}{l}100 \\
100 \\
100 \\
\end{array}$ & & Tr & & & & & $\mathrm{Tr}$ & & & & $\begin{array}{l}\mathrm{Tr} \\
\mathrm{Tr} \\
\mathrm{Tr}\end{array}$ & $\begin{array}{l}\mathrm{Tr} \\
\mathrm{Tr}\end{array}$ & $\begin{array}{r}33 \\
9 \\
12 \\
\end{array}$ & $\begin{array}{l}66 \\
90 \\
86 \\
\end{array}$ & & & & & & $\begin{array}{r}2 . \\
10 . \\
7 .\end{array}$ & $\begin{array}{l}53 . \\
259 .\end{array}$ \\
\hline $3, \mathrm{CC}$ & 39 & & & 100 & & & 100 & $\mathrm{Tr}_{\mathrm{r}}$ & & & & & & & & & & $\mathrm{Tr}$ & & 91 & 9 & & $\mathrm{Tr}$ & & & & .1 & \\
\hline $\begin{array}{l}4-1,85 \\
4-2,65 \\
4-3,85 \\
4-4,85 \\
4-5,85 \\
4-6,85 \\
4, C C\end{array}$ & \begin{tabular}{|l|}
58 \\
62 \\
58 \\
51 \\
63 \\
66 \\
63
\end{tabular} & & & $\begin{array}{l}100 \\
100 \\
100 \\
100 \\
100 \\
100 \\
100\end{array}$ & & & $\begin{array}{l}100 \\
100 \\
100 \\
100 \\
100 \\
100 \\
100\end{array}$ & $\begin{array}{l}\mathrm{Tr} \\
\mathrm{Tr} \\
\mathrm{Tr}\end{array}$ & & & & & & $\begin{array}{l}\mathrm{Tr} \\
\mathrm{Tr} \\
\mathrm{Tr} \\
\mathrm{Tr}\end{array}$ & $\mathrm{Tr}$ & & & $\begin{array}{l}\mathrm{Tr} \\
\mathrm{Tr} \\
\mathrm{Tr} \\
\mathrm{Tr}\end{array}$ & $\begin{array}{l}\mathrm{Tr} \\
\mathrm{Tr} \\
\mathrm{Tr} \\
\mathrm{Tr} \\
\mathrm{Tr} \\
\mathrm{P}\end{array}$ & $\begin{array}{l}44 \\
70 \\
31 \\
38 \\
33 \\
25 \\
20\end{array}$ & $\begin{array}{l}55 \\
30 \\
67 \\
61 \\
67 \\
75 \\
79\end{array}$ & & $\begin{array}{l}\mathrm{Tr} \\
\mathrm{Tr}\end{array}$ & Tr & & 400. & $\begin{array}{l}1.3 \\
.4 \\
2.1 \\
1.6 \\
2 . \\
3 . \\
4.2\end{array}$ & $\begin{array}{r}150 . \\
81 . \\
187 . \\
300 . \\
74 .\end{array}$ \\
\hline $\begin{array}{l}5-1,85 \\
5-2,75 \\
5-3,85 \\
5-5,85 \\
5,0 C \\
\end{array}$ & \begin{tabular}{|l|}
62 \\
62 \\
66 \\
61 \\
75 \\
\end{tabular} & & & $\begin{array}{l}100 \\
100 \\
100 \\
100 \\
100\end{array}$ & & $\mathrm{Tr}$ & $\begin{array}{r}100 \\
100 \\
99 \\
100 \\
99\end{array}$ & $\begin{array}{l}\mathrm{Tr} \\
\mathrm{Tr} \\
\mathrm{Tr}\end{array}$ & \begin{tabular}{|l}
$\mathrm{Tr}$ \\
\end{tabular} & & & & & $\mathrm{Tr}$ & & & & $\mathrm{Tr}$ & $\begin{array}{l}\mathrm{Tr} \\
\mathrm{Tr} \\
\mathrm{Tr} \\
\mathrm{Tr} \\
\mathrm{Tr}\end{array}$ & $\begin{array}{l}44 \\
63 \\
13 \\
25 \\
32 \\
\end{array}$ & $\begin{array}{l}55 \\
36 \\
86 \\
75 \\
66 \\
\end{array}$ & & $\begin{array}{l}\mathrm{Tr} \\
\mathrm{Tr} \\
\mathrm{Tr}\end{array}$ & $\begin{array}{l}\mathrm{Tr} \\
\mathrm{Tr}\end{array}$ & & $\begin{array}{l}241 . \\
293 .\end{array}$ & $\begin{array}{l}1.3 \\
.6 \\
6.5 \\
3 . \\
2.1 \\
\end{array}$ & $\begin{array}{r}250 . \\
51 . \\
300 . \\
99 .\end{array}$ \\
\hline $\begin{array}{l}6-1,85 \\
6-2,85 \\
6-3,85 \\
6-4,85 \\
6-5,85 \\
5-6,85 \\
6, \mathrm{CC}\end{array}$ & \begin{tabular}{|l|}
45 \\
40 \\
41 \\
48 \\
49 \\
51 \\
49 \\
\end{tabular} & & & $\begin{array}{l}100 \\
100 \\
100 \\
100 \\
100 \\
100 \\
100\end{array}$ & & $\begin{array}{l}\mathrm{Tr} \\
\mathrm{Tr} \\
\mathrm{Tr} \\
\mathrm{Tr}\end{array}$ & $\begin{array}{r}98 \\
89 \\
99 \\
100 \\
98 \\
98 \\
99\end{array}$ & $\begin{array}{l}\mathrm{P} \\
10 \\
\mathrm{Tr} \\
\mathrm{P} \\
\mathrm{P} \\
\mathrm{P}\end{array}$ & \begin{tabular}{|l}
$\mathrm{Tr}$ \\
$\mathrm{Tr}$ \\
$\mathrm{Tr}$ \\
$\mathrm{Tr}$
\end{tabular} & Tr & & & & & & & & $\mathrm{Tr}$ & $\begin{array}{l}\mathrm{Tr} \\
\mathrm{Tr} \\
\mathrm{Tr} \\
\mathrm{Tr} \\
\mathrm{Tr} \\
\mathrm{Tr} \\
\mathrm{P}\end{array}$ & $\begin{array}{l}28 \\
50 \\
14 \\
11 \\
21 \\
23 \\
44 \\
\end{array}$ & $\begin{array}{l}70 \\
39 \\
84 \\
89 \\
76 \\
76 \\
53 \\
\end{array}$ & & $\begin{array}{l}\mathrm{Tr} \\
\mathrm{Tr} \\
\mathrm{Tr} \\
\mathrm{Tr} \\
\mathrm{Tr} \\
\mathrm{Tr} \\
\mathrm{Tr}\end{array}$ & $\begin{array}{l}\mathrm{p} \\
{ }^{\prime} \\
\mathrm{Tr} \\
\mathrm{Tr} \\
\mathrm{P} \\
\mathrm{Tr}\end{array}$ & & $\begin{array}{c}70 . \\
9.4 \\
350 . \\
101 . \\
65 . \\
96 . \\
\end{array}$ & $\begin{array}{l}.5 \\
.8 \\
6 . \\
8 . \\
3.4 \\
3.3 \\
1.2\end{array}$ & $\begin{array}{r}250 . \\
66 . \\
300 . \\
400 . \\
119 . \\
500 . \\
26 .\end{array}$ \\
\hline $\begin{array}{l}7-1,85 \\
7-2,85 \\
7-3,85 \\
7-4,85 \\
7-5,85 \\
7-6,85 \\
7, \mathrm{CC}\end{array}$ & \begin{tabular}{|l|}
64 \\
67 \\
67 \\
64 \\
62 \\
62 \\
62 \\
\end{tabular} & & & $\begin{array}{l}100 \\
100 \\
100 \\
100 \\
100 \\
100 \\
100\end{array}$ & & $\begin{array}{l}\mathrm{Tr} \\
\\
\mathrm{Tr} \\
\mathrm{Tr} \\
\mathrm{Tr} \\
\mathrm{Tr}\end{array}$ & $\begin{array}{r}100 \\
99 \\
98 \\
99 \\
98 \\
99 \\
97\end{array}$ & $\begin{array}{l}\mathrm{Tr} \\
\mathrm{Tr} \\
\mathrm{P} \\
\mathrm{Tr} \\
\mathrm{Tr} \\
\mathrm{P} \\
\mathrm{P}\end{array}$ & \begin{tabular}{|l} 
Tr \\
\\
Tr \\
Tr \\
Tr \\
Tr
\end{tabular} & & & & & & & & & $\begin{array}{l}\mathrm{Tr} \\
\mathrm{Tr}\end{array}$ & $\begin{array}{l}\mathrm{Tr} \\
5 \\
\mathrm{Tr} \\
\mathrm{P} \\
\mathrm{Pr} \\
\mathrm{Tr}\end{array}$ & $\begin{array}{l}20 \\
40 \\
43 \\
20 \\
44 \\
41 \\
15\end{array}$ & $\begin{array}{l}80 \\
60 \\
51 \\
79 \\
52 \\
57 \\
81\end{array}$ & & $\begin{array}{l}\mathrm{Tr} \\
\mathrm{Tr}\end{array}$ & $\begin{array}{l}\mathrm{Tr} \\
\mathrm{Tr} \\
\mathrm{P} \\
\mathrm{Tr} \\
\mathrm{Tr} \\
\mathrm{Tr} \\
\mathrm{P}\end{array}$ & & $\begin{array}{r}500 . \\
167 . \\
71 . \\
250 . \\
97 . \\
111 . \\
49 .\end{array}$ & $\begin{array}{l}4 . \\
1.5 \\
1.2 \\
4 . \\
1.2 \\
1.4 \\
5.3\end{array}$ & $\begin{array}{r}300 . \\
21 . \\
200 . \\
26 . \\
64 . \\
123 .\end{array}$ \\
\hline $\begin{array}{l}8-1,85 \\
8-2,85 \\
8-3,85 \\
8-4,85 \\
8-5,85 \\
8-6,85 \\
8, \mathrm{CC} \\
\end{array}$ & \begin{tabular}{|l|l}
61 \\
49 \\
65 \\
52 \\
56 \\
62 \\
\end{tabular} & $\mathrm{Tr}$ & & $\begin{array}{l}100 \\
100 \\
100 \\
100 \\
100 \\
100 \\
100 \\
\end{array}$ & & $\begin{array}{l}\mathrm{Tr} \\
\mathrm{Tr} \\
\mathrm{Tr}\end{array}$ & $\begin{array}{r}100 \\
99 \\
89 \\
99 \\
96 \\
93 \\
99 \\
\end{array}$ & $\begin{array}{r}\mathrm{Tr} \\
\mathrm{Tr} \\
11 \\
\mathrm{Tr} \\
3 \\
7 \\
\mathrm{Tr} \\
\mathrm{Tr}\end{array}$ & $\begin{array}{l}\mathrm{Tr} \\
\mathrm{Tr} \\
\mathrm{Tr}\end{array}$ & & & & & Tr & & & & $\begin{array}{l}\mathrm{Tr} \\
\mathrm{Tr} \\
\mathrm{Tr} \\
\mathrm{Tr} \\
\mathrm{Tr}\end{array}$ & $\begin{array}{r}\mathrm{Tr} \\
\mathrm{Tr} \\
\mathrm{Tr} \\
4 \\
4 \\
\mathrm{Tr} \\
\mathrm{Tr}\end{array}$ & $\begin{array}{l}25 \\
33 \\
45 \\
14 \\
41 \\
52 \\
40\end{array}$ & $\begin{array}{l}74 \\
66 \\
42 \\
85 \\
50 \\
41 \\
60\end{array}$ & & $\begin{array}{l}\mathrm{Tr} \\
\mathrm{Tr} \\
\mathrm{Tr} \\
\mathrm{Tr} \\
\mathrm{Tr}\end{array}$ & $\begin{array}{r}\mathrm{Tr} \\
\mathrm{Tr} \\
11 \\
\mathrm{Tr} \\
3 \\
6 \\
\mathrm{Tr}\end{array}$ & & $\begin{array}{r}400 . \\
450 . \\
8 . \\
350 . \\
29 . \\
15 . \\
250 .\end{array}$ & $\begin{array}{l}3 . \\
2 . \\
.9 \\
6 . \\
1.2 \\
.8 \\
1.5\end{array}$ & $\begin{array}{r}300 . \\
50 . \\
300 . \\
13 . \\
137 . \\
150 .\end{array}$ \\
\hline $\begin{array}{l}9-1,85 \\
9-2,85 \\
9-3,85 \\
9-4,85 \\
9-5,85 \\
9-6,85 \\
9, \mathrm{CC}\end{array}$ & \begin{tabular}{|l|}
55 \\
60 \\
59 \\
60 \\
63 \\
59 \\
61 \\
\end{tabular} & & & $\begin{array}{l}100 \\
100 \\
100 \\
100 \\
100 \\
100 \\
100\end{array}$ & & $\mathrm{Tr}$ & $\begin{array}{r}98 \\
99 \\
100 \\
98 \\
98 \\
100 \\
98 \\
99\end{array}$ & $\begin{array}{l}\mathrm{P} \\
\mathrm{Tr} \\
\mathrm{Tr} \\
\mathrm{P} \\
\mathrm{P} \\
\mathrm{P}\end{array}$ & \begin{tabular}{|l|l|} 
Tr \\
\end{tabular} & & & & & $\begin{array}{l}\text { Tr } \\
\text { Tr } \\
\text { Tr }\end{array}$ & & & & $\begin{array}{l}\mathrm{Tr} \\
\mathrm{Tr} \\
\mathrm{Tr} \\
\mathrm{Tr}\end{array}$ & $\begin{array}{l}\mathrm{Tr} \\
\mathrm{Tr} \\
\mathrm{Tr} \\
\mathrm{P} \\
\mathrm{Tr} \\
\mathrm{Tr} \\
\mathrm{Tr}\end{array}$ & $\begin{array}{r}33 \\
30 \\
9 \\
38 \\
14 \\
38 \\
26 \\
\end{array}$ & $\begin{array}{l}65 \\
70 \\
90 \\
58 \\
85 \\
60 \\
72\end{array}$ & & $\begin{array}{l}\mathrm{Tr} \\
\mathrm{Tr} \\
\mathrm{Tr} \\
\mathrm{Tr}\end{array}$ & $\begin{array}{l}\mathrm{P} \\
\mathrm{Tr} \\
\mathrm{Tr} \\
\mathrm{P} \\
\mathrm{P} \\
\mathrm{Pr}\end{array}$ & & $\begin{array}{r}75 . \\
150 . \\
550 . \\
49 . \\
79 . \\
137 . \\
\end{array}$ & $\begin{array}{l}2 . \\
2.3 \\
10 . \\
1.5 \\
6 . \\
1.6 \\
2.8 \\
\end{array}$ & $\begin{array}{l}200 . \\
210 . \\
250 . \\
37 . \\
300 . \\
201 .\end{array}$ \\
\hline $\begin{array}{l}10-2,82 \\
10-5,85 \\
10, \mathrm{cC}\end{array}$ & \begin{tabular}{|l|}
47 \\
31 \\
44
\end{tabular} & & & $\begin{array}{l}100 \\
100 \\
100\end{array}$ & & $\begin{array}{l}\mathrm{Tr} \\
\mathrm{Tr} \\
\mathrm{Tr}\end{array}$ & $\begin{array}{l}99 \\
94 \\
88\end{array}$ & $\begin{array}{r}\text { Tr } \\
6 \\
11\end{array}$ & \begin{tabular}{|l|}
$\mathrm{Tr}$ \\
$\mathrm{Tr}$ \\
$\mathrm{Tr}$
\end{tabular} & $\mathrm{Tr}$ & & & & Tr & & & & $\mathrm{Tr}$ & $\begin{array}{l}\mathrm{T}_{\mathrm{r}} \\
\mathrm{T}_{\mathrm{r}} \\
\mathrm{P}\end{array}$ & $\begin{array}{l}20 \\
56 \\
34\end{array}$ & $\begin{array}{l}78 \\
38 \\
52\end{array}$ & & $\begin{array}{l}\mathrm{Tr} \\
\mathrm{Tr}\end{array}$ & $\begin{array}{r}\mathrm{Tr} \\
5 \\
11\end{array}$ & $\mathrm{Tr}_{\mathrm{r}}$ & \begin{tabular}{|c|}
250. \\
20. \\
8.2
\end{tabular} & $\begin{array}{r}4 . \\
1.5\end{array}$ & $\begin{array}{r}200 . \\
67 . \\
31 .\end{array}$ \\
\hline $\begin{array}{l}11-2,85 \\
11-5,85 \\
11, \propto C\end{array}$ & $\begin{array}{l}51 \\
52 \\
41\end{array}$ & & & $\begin{array}{l}100 \\
100 \\
100\end{array}$ & & $\begin{array}{l}\mathrm{Tr} \\
\mathrm{Tr}\end{array}$ & $\begin{array}{l}99 \\
99 \\
97\end{array}$ & $\begin{array}{l}\text { Tr } \\
\text { Tr } \\
P\end{array}$ & $\begin{array}{l}\text { Tr } \\
\text { Tr }\end{array}$ & & & & & & & & & $\begin{array}{l}\mathrm{Tr} \\
\mathrm{Tr}\end{array}$ & $\begin{array}{l}\mathrm{Tr} \\
\mathrm{Tr} \\
\mathrm{P}\end{array}$ & $\begin{array}{l}49 \\
30 \\
33\end{array}$ & $\begin{array}{l}49 \\
69 \\
61\end{array}$ & & $\begin{array}{l}\mathrm{Tr} \\
\mathrm{Tr} \\
\mathrm{Tr}\end{array}$ & $\begin{array}{l}\mathrm{Tr} \\
\mathrm{Tr} \\
\mathrm{P}\end{array}$ & & \begin{tabular}{|c|}
200. \\
250. \\
40.
\end{tabular} & $\begin{array}{l}1 . \\
2.3 \\
1.9\end{array}$ & $\begin{array}{c}200 . \\
350 . \\
32 .\end{array}$ \\
\hline $\begin{array}{l}12-2,85 \\
12-5,85 \\
12, \propto C\end{array}$ & \begin{tabular}{|l}
35 \\
43 \\
58 \\
\end{tabular} & & & $\begin{array}{l}100 \\
100 \\
100\end{array}$ & & $\begin{array}{l}\mathrm{Tr} \\
\mathrm{Tr}\end{array}$ & $\begin{array}{l}98 \\
97 \\
97\end{array}$ & $\begin{array}{l}\mathrm{P} \\
\mathrm{P} \\
{ }_{4}\end{array}$ & \begin{tabular}{|l|}
$\mathrm{Tr}$ \\
$\mathrm{Tr}$
\end{tabular} & & & & & & & & & $\begin{array}{l}\mathrm{Tr} \\
\mathrm{Tr}\end{array}$ & $\begin{array}{l}\mathrm{Tr}_{\mathrm{r}} \\
\mathrm{Tr} \\
\mathrm{Tr}\end{array}$ & $\begin{array}{l}39 \\
39 \\
24\end{array}$ & $\begin{array}{l}58 \\
58 \\
72\end{array}$ & & $\begin{array}{l}\mathrm{Tr} \\
\mathrm{Tr}\end{array}$ & $\begin{array}{l}\mathrm{P} \\
\mathrm{P} \\
4\end{array}$ & & \begin{tabular}{|l}
50. \\
50. \\
28.
\end{tabular} & $\begin{array}{l}1.5 \\
1.5 \\
3 .\end{array}$ & $\begin{array}{l}150 . \\
300 . \\
103 .\end{array}$ \\
\hline $\begin{array}{l}13-2,85 \\
13-5,85 \\
13, \mathrm{CC}\end{array}$ & \begin{tabular}{|l}
58 \\
36 \\
58
\end{tabular} & & & $\begin{array}{l}100 \\
100 \\
100\end{array}$ & & $\mathrm{Tr}$ & $\begin{array}{r}100 \\
99 \\
100\end{array}$ & $\begin{array}{l}\mathrm{Tr} \\
\mathrm{Tr}\end{array}$ & Tr & & & & & & & & & $\mathrm{Tr}$ & $\begin{array}{l}\mathrm{Tr}_{\mathrm{T}} \\
\mathrm{Tr}\end{array}$ & $\begin{array}{l}20 \\
44 \\
22\end{array}$ & $\begin{array}{l}80 \\
55 \\
77\end{array}$ & & $\begin{array}{l}\mathrm{Tr} \\
\mathrm{Tr}\end{array}$ & $\mathrm{Tr}$ & & 250. & $\begin{array}{l}4 . \\
1.2 \\
3.4\end{array}$ & $\begin{array}{l}400 . \\
195 .\end{array}$ \\
\hline $\begin{array}{l}14-2,85 \\
145,85 \\
14, \mathrm{CC}\end{array}$ & \begin{tabular}{|l|}
50 \\
70 \\
60 \\
\end{tabular} & & & $\begin{array}{l}100 \\
100 \\
100\end{array}$ & & & $\begin{array}{l}100 \\
100 \\
100\end{array}$ & $\mathrm{Tr}_{\mathrm{T}}$ & & & & & & & & & & $\begin{array}{l}\mathrm{T}_{\mathrm{t}} \\
\mathrm{Tr}\end{array}$ & $\begin{array}{l}\mathrm{Tr} \\
\mathrm{Tr}\end{array}$ & $\begin{array}{l}25 \\
17 \\
20\end{array}$ & $\begin{array}{l}74 \\
84 \\
80\end{array}$ & & $\mathrm{Tr}$ & & & & $\begin{array}{l}3 . \\
5 . \\
4.1\end{array}$ & $\begin{array}{l}300 . \\
167 .\end{array}$ \\
\hline $15-2,85$ & 58 & & & 100 & & $\mathrm{Tr}$ & 100 & & \begin{tabular}{|l|} 
Tr \\
\end{tabular} & & & & & & & & & & Tr & 40 & 60 & & & & & & 1.5 & 150. \\
\hline $\begin{array}{l}16-2,85 \\
16-5,85 \\
16, \mathrm{CC}\end{array}$ & \begin{tabular}{|l|}
41 \\
50 \\
48
\end{tabular} & & & $\begin{array}{l}100 \\
100 \\
100\end{array}$ & & $\begin{array}{l}\mathrm{Tr} \\
\mathrm{Tr}\end{array}$ & $\begin{array}{l}100 \\
100 \\
100\end{array}$ & & \begin{tabular}{|l} 
Tr \\
Tr
\end{tabular} & & & & & $\operatorname{Tr}$ & Tr & & & $\begin{array}{l}\mathrm{Tr} \\
\mathrm{Tr}\end{array}$ & $\begin{array}{l}\mathrm{Tr} \\
\mathrm{Tr} \\
\mathrm{Tr}\end{array}$ & $\begin{array}{r}20 \\
9 \\
24\end{array}$ & $\begin{array}{l}79 \\
90 \\
76\end{array}$ & & & & & & $\begin{array}{c}4 . \\
10 . \\
3.1\end{array}$ & $\begin{array}{l}200 . \\
225 . \\
226 .\end{array}$ \\
\hline
\end{tabular}




\begin{tabular}{|c|c|c|c|c|c|c|c|c|c|c|c|c|c|c|c|c|c|c|c|c|c|c|c|c|c|c|c|c|}
\hline $\begin{array}{l}\text { Core, Section } \\
\text { Top of } \\
\text { Interval } \\
(\mathrm{cm})\end{array}$ & 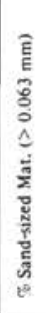 & 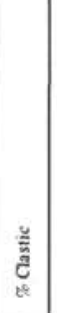 & 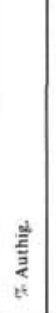 & $\frac{c}{\frac{c}{m}}$ & 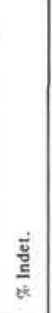 & 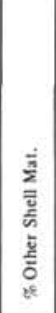 & \begin{tabular}{l|} 
हैं \\
वे. \\
है \\
है
\end{tabular} & 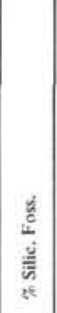 & $\frac{5}{\frac{5}{2}}$ & 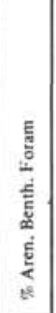 & 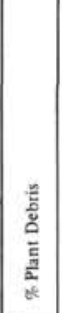 & 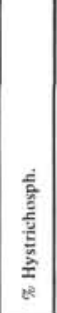 & 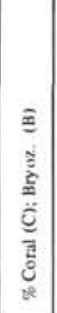 & $\begin{array}{l}\text { o } \\
\frac{\mathrm{d}}{3} \\
\text { of } \\
\text { of }\end{array}$ & 总 & 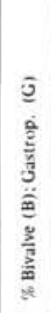 & 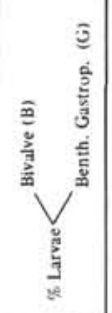 & 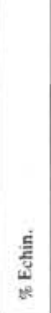 & 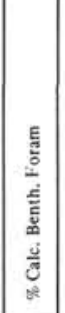 & 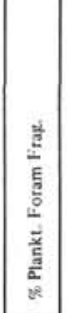 & 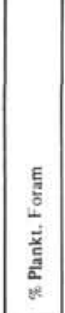 & 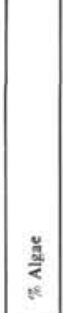 & 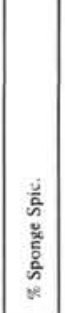 & 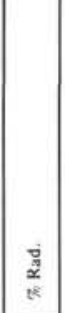 & 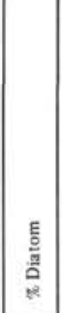 & 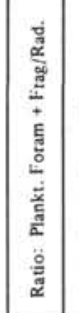 & 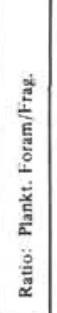 & 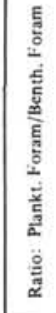 \\
\hline $\begin{array}{l}\text { Sito } 237 \\
17-2,85 \\
17-5,90 \\
17, \mathrm{CC}\end{array}$ & 39 & & & $\begin{array}{l}100 \\
100 \\
100 \\
\end{array}$ & & $\mathrm{Tr}$ & $\begin{array}{l}100 \\
100 \\
100\end{array}$ & $\mathrm{Tr}$ & Tr & & & & & $\operatorname{Tr}$ & & & & $\mathrm{Tr}$ & $\begin{array}{l}\mathrm{Tr} \\
\mathrm{Tr}\end{array}$ & $\begin{array}{l}49 \\
49 \\
10\end{array}$ & $\begin{array}{l}50 \\
50 \\
89\end{array}$ & & & $\mathrm{Tr}$ & & 26. & $\begin{array}{l}1 . \\
1 . \\
9 .\end{array}$ & $\begin{array}{l}60 . \\
61 .\end{array}$ \\
\hline $\begin{array}{l}18-2,85 \\
18-5,85 \\
18, \mathrm{CC}\end{array}$ & $\begin{array}{l}60 \\
57 \\
50\end{array}$ & & & $\begin{array}{l}100 \\
100 \\
100\end{array}$ & & $\begin{array}{l}\mathrm{T} t \\
\mathrm{Tt}\end{array}$ & $\begin{array}{r}99 \\
100 \\
100\end{array}$ & \begin{tabular}{c|}
$\mathrm{Tr}$ \\
$\mathrm{Tr}$
\end{tabular} & & & & & & & & & & $\begin{array}{l}\mathrm{Tr} \\
\mathrm{Tr}\end{array}$ & $\begin{array}{l}\mathrm{Tr} \\
\mathrm{Tr}\end{array}$ & $\begin{array}{l}35 \\
30 \\
15\end{array}$ & $\begin{array}{l}64 \\
69 \\
85\end{array}$ & & $\begin{array}{l}\mathrm{Tr} \\
\mathrm{Tr}\end{array}$ & & & & $\begin{array}{l}1.8 \\
2.3 \\
5.6\end{array}$ & $\begin{array}{l}144 . \\
350 .\end{array}$ \\
\hline $\begin{array}{l}19 \cdot 2,85 \\
19 \cdot 5,85 \\
19 . \mathrm{CC}\end{array}$ & $\begin{array}{l}43 \\
51 \\
43 \\
\end{array}$ & & & $\begin{array}{l}100 \\
100 \\
100 \\
\end{array}$ & & $\begin{array}{l}\mathrm{Tr} \\
\mathrm{Tr} \\
\mathrm{Tr}\end{array}$ & $\begin{array}{r}100 \\
99 \\
100\end{array}$ & $\begin{array}{l}\mathrm{Tr} \\
\mathrm{Tr}\end{array}$ & $\begin{array}{l}\text { Trt } \\
\text { Tr } \\
\text { Tr }\end{array}$ & & & & & $\mathrm{Tr}$ & & & & $\begin{array}{l}\mathrm{Tr} \\
\mathrm{Tr}\end{array}$ & $\begin{array}{l}\mathrm{Tr} \\
\mathrm{Tr} \\
\mathrm{Tr}\end{array}$ & $\begin{array}{l}20 \\
11 \\
18\end{array}$ & $\begin{array}{l}79 \\
87 \\
81\end{array}$ & & Tr & $\mathrm{Tr}$ & & 299. & $\begin{array}{l}4 . \\
8 . \\
4.5\end{array}$ & $\begin{array}{l}400 . \\
400 . \\
299 .\end{array}$ \\
\hline $\begin{array}{l}20-2,85 \\
20-5,85 \\
20, C C\end{array}$ & $\begin{array}{l}42 \\
36 \\
34\end{array}$ & & & $\begin{array}{l}100 \\
100 \\
100\end{array}$ & & $\begin{array}{l}\mathrm{Tr} \\
\mathrm{Tr}\end{array}$ & $\begin{array}{r}100 \\
100 \\
99\end{array}$ & $\mathrm{Tr}$ & $\begin{array}{l}\text { Tr } \\
\text { Ir }\end{array}$ & & & & & & & & & $\begin{array}{l}\mathrm{Tr} \\
\mathrm{Tr}\end{array}$ & $\begin{array}{l}\mathrm{Tr} \\
\mathrm{Tr} \\
\mathrm{P}\end{array}$ & $\begin{array}{l}26 \\
14 \\
16\end{array}$ & $\begin{array}{l}73 \\
85 \\
82\end{array}$ & & & $\mathrm{Tr}$ & & 195. & $\begin{array}{l}.8 \\
6 . \\
5.1\end{array}$ & $\begin{array}{r}105 . \\
150 . \\
65 .\end{array}$ \\
\hline $\begin{array}{l}21-2,85 \\
21-5,85 \\
21, \mathrm{CC}\end{array}$ & $\begin{array}{l}29 \\
26 \\
27\end{array}$ & & & $\begin{array}{l}100 \\
100 \\
100\end{array}$ & & $\begin{array}{l}\mathrm{Tr} \\
\mathrm{Tr} \\
\mathrm{Tr}\end{array}$ & $\begin{array}{r}99 \\
100 \\
100\end{array}$ & $\mathrm{Tt}$ & $\begin{array}{l}\mathrm{Tr} \\
\mathrm{Tr} \\
\mathrm{Tr}\end{array}$ & $\mathrm{Tr}$ & & & & $\mathrm{Tr}_{\mathrm{r}}$ & & & & $\begin{array}{l}\mathrm{Tr} \\
\mathrm{Tr}\end{array}$ & $\begin{array}{l}\mathrm{Tr} \\
\mathrm{Tr} \\
\mathrm{Tr}\end{array}$ & $\begin{array}{l}20 \\
17 \\
34\end{array}$ & $\begin{array}{l}80 \\
82 \\
65\end{array}$ & & $\mathrm{Tr}$ & & & & $\begin{array}{l}4 . \\
5 . \\
1.9\end{array}$ & $\begin{array}{l}400 . \\
167 . \\
131 .\end{array}$ \\
\hline $\begin{array}{l}22-2,85 \\
22, \mathrm{CC}\end{array}$ & $\begin{array}{l}25 \\
20\end{array}$ & & & $\begin{array}{l}100 \\
100\end{array}$ & & $\begin{array}{l}\mathrm{Tr} \\
\mathrm{Tr}\end{array}$ & $\begin{array}{l}100 \\
100\end{array}$ & $\begin{array}{ll}\mathrm{Tr} \\
\end{array}$ & $\begin{array}{l}\mathrm{Tr} \\
\mathrm{Tr}\end{array}$ & & & & & $T_{r}$ & & & & & $\begin{array}{c}\mathrm{Tr} \\
4\end{array}$ & $\begin{array}{l}30 \\
60\end{array}$ & $\begin{array}{l}69 \\
36\end{array}$ & & & $\mathrm{Tr}$ & & 350. & $\begin{array}{r}2.3 \\
.6\end{array}$ & $\begin{array}{r}70 . \\
9 .\end{array}$ \\
\hline $\begin{array}{l}23-2,85 \\
23-5,85 \\
23, \mathrm{CC}\end{array}$ & $\begin{array}{l}6 \\
6 \\
9\end{array}$ & & & $\begin{array}{l}100 \\
100 \\
100\end{array}$ & & $\begin{array}{l}\mathrm{Tr} \\
\mathrm{Tr} \\
\mathrm{P}\end{array}$ & $\begin{array}{l}99 \\
99 \\
97\end{array}$ & $\begin{array}{l}\mathrm{Tr} \\
\mathrm{Tr}\end{array}$ & $\begin{array}{l}\text { Tr } \\
\text { Tr } \\
\text { P }\end{array}$ & $\operatorname{Tr}$ & & & & $\begin{array}{l}\mathrm{Tr} \\
\mathrm{P} \\
\mathrm{Tr}\end{array}$ & & & & $\mathrm{Tr}$ & $\begin{array}{c}7 \\
\mathrm{Tr}_{\mathrm{r}} \\
3\end{array}$ & $\begin{array}{l}58 \\
88 \\
80\end{array}$ & $\begin{array}{l}35 \\
10 \\
13\end{array}$ & & $\begin{array}{l}\mathrm{Tr} \\
\mathrm{Tr}\end{array}$ & & & & $\begin{array}{l}.6 \\
.1 \\
.2 \\
\end{array}$ & $\begin{array}{r}5 . \\
17 . \\
3.5\end{array}$ \\
\hline $\begin{array}{l}24-2,85 \\
24, \mathrm{CC}\end{array}$ & 5 & & & $\begin{array}{l}100 \\
100\end{array}$ & & $\begin{array}{l}\mathrm{P} \\
\mathrm{Tr}\end{array}$ & $\begin{array}{l}96 \\
98\end{array}$ & \begin{tabular}{l|}
$\mathrm{P}$ \\
$\mathrm{Tr}$
\end{tabular} & $\begin{array}{l}\mathrm{P} \\
\mathrm{Tr}\end{array}$ & & & & & $\mathrm{T}_{t}$ & & & & $\mathrm{Tr}$ & $\begin{array}{l}4 \\
5\end{array}$ & $\begin{array}{l}73 \\
48\end{array}$ & $\begin{array}{l}19 \\
45\end{array}$ & & $\mathrm{Tr}$ & $\begin{array}{l}\mathrm{Tr} \\
\mathrm{Tr}\end{array}$ & & $\begin{array}{l}24 . \\
55 .\end{array}$ & $1^{3}$. & $\begin{array}{r}4 . \\
10 .\end{array}$ \\
\hline $\begin{array}{l}25 \cdot 5,85 \\
25, \mathrm{CC}\end{array}$ & 7 & & & $\begin{array}{l}100 \\
100\end{array}$ & $\mathrm{Tr}$ & & $\begin{array}{l}4 \\
5\end{array}$ & \begin{tabular}{l|}
96 \\
95
\end{tabular} & & & & & & & & & & & & $\begin{array}{l}\mathrm{Tr} \\
\mathrm{P}\end{array}$ & $\begin{array}{l}4 \\
3\end{array}$ & & $\begin{array}{l}9 \\
5\end{array}$ & $\begin{array}{l}87 \\
90\end{array}$ & & $\begin{array}{l}.04 \\
.03\end{array}$ & $\begin{array}{l}4 . \\
1.5\end{array}$ & \\
\hline $\begin{array}{l}26-2,85 \\
26, \subset C\end{array}$ & $\begin{array}{r}5 \\
48\end{array}$ & & & $\begin{array}{l}100 \\
100\end{array}$ & & $\mathrm{Tr}$ & $\begin{array}{l}12 \\
P\end{array}$ & \begin{tabular}{l|}
88 \\
99
\end{tabular} & $\mathrm{Tr}$ & & & & & $\mathrm{Tr}$ & & & & & . & 10 & $\begin{array}{l}\mathrm{P} \\
\mathrm{Tr}\end{array}$ & & 8 & $\begin{array}{l}80 \\
99\end{array}$ & & $\begin{array}{l}.2 \\
.01\end{array}$ & .2 & \\
\hline $\begin{array}{l}27.2,90 \\
27, \mathrm{CC}\end{array}$ & $\begin{array}{l}10 \\
12 \\
\end{array}$ & & & $\begin{array}{l}100 \\
100\end{array}$ & & & $\begin{array}{l}10 \\
P\end{array}$ & $\begin{array}{l}90 \\
98 \\
\end{array}$ & & & & & & & & & & & $\mathrm{Tr}$ & $\begin{array}{l}\mathrm{P} \\
\mathrm{P}\end{array}$ & $\begin{array}{r}8 \\
\mathrm{Tr}\end{array}$ & & $\mathrm{P}^{4}$ & $\begin{array}{l}86 \\
97 \\
\end{array}$ & & $\begin{array}{l}.1 \\
.01\end{array}$ & 3.2 & \\
\hline $\begin{array}{l}28-2,95 \\
28-5,85\end{array}$ & $\begin{array}{l}12 \\
14 \\
\end{array}$ & & & $\begin{array}{l}100 \\
100\end{array}$ & & $\mathrm{Tr}$ & $\begin{array}{r}17 \\
8\end{array}$ & \begin{tabular}{l|}
83 \\
92 \\
\end{tabular} & $\mathrm{Tr}$ & & & & & $\begin{array}{l}\mathrm{Tr} \\
\mathrm{Tr}\end{array}$ & & & & & $P$ & $\begin{array}{l}\mathrm{P} \\
\mathrm{Tr}\end{array}$ & $\begin{array}{r}12 \\
7\end{array}$ & & $\begin{array}{r}8 \\
21 \\
\end{array}$ & $\begin{array}{l}75 \\
71 \\
\end{array}$ & & .2 & $\begin{array}{c}4.4 \\
10 .\end{array}$ & 6. \\
\hline $\begin{array}{l}29-2,60 \\
29-2,95 \\
29-5,95\end{array}$ & $\begin{array}{r}14 \\
19 \\
9\end{array}$ & $\mathrm{Tr}$ & & $\begin{array}{l}100 \\
100 \\
100\end{array}$ & & $\mathrm{Tr}$ & $\begin{array}{l}5 \\
8 \\
9\end{array}$ & \begin{tabular}{l|}
95 \\
92 \\
91
\end{tabular} & Tr & & & & & & & & & & $\mathrm{Tr}$ & $\begin{array}{l}\mathrm{Tr} \\
\mathrm{P} \\
\mathrm{Tr}\end{array}$ & $\begin{array}{l}4 \\
7 \\
8\end{array}$ & & $\begin{array}{r}9 \\
5 \\
18\end{array}$ & $\begin{array}{l}86 \\
87 \\
73\end{array}$ & & $\begin{array}{l}.06 \\
.09 \\
.1\end{array}$ & $\begin{array}{l}5 . \\
5.8 \\
8.8\end{array}$ & 69. \\
\hline $\begin{array}{l}30-2,75 \\
30-5,110\end{array}$ & $\begin{array}{r}12 \\
9\end{array}$ & & & $\begin{array}{l}100 \\
100\end{array}$ & & & $\begin{array}{l}5 \\
5\end{array}$ & \begin{tabular}{l|}
95 \\
95
\end{tabular} & & & & & & & & & & & $T r$ & $\begin{array}{l}\mathrm{Tr} \\
\mathrm{Tr}\end{array}$ & $\begin{array}{l}4 \\
4\end{array}$ & & $\begin{array}{r}9 \\
16\end{array}$ & $\begin{array}{l}86 \\
79\end{array}$ & & $\begin{array}{l}.06 \\
.06\end{array}$ & $\begin{array}{l}5 . \\
5 .\end{array}$ & 25. \\
\hline $31-1,80$ & 10 & & & 100 & & $T_{r}$ & 5 & 95 & $\mathrm{~T}_{\mathrm{t}}$ & & & & & & & & & $\mathrm{Tr}$ & $\mathrm{Tr}$ & $\mathrm{Tr}$ & 4 & & 19 & 76 & & .05 & 10. & 20. \\
\hline $\begin{array}{l}32-3,40 \\
32-5,65 \\
32, \mathrm{CC}\end{array}$ & \begin{tabular}{|r|}
7 \\
6 \\
16
\end{tabular} & & & $\begin{array}{l}100 \\
100 \\
100\end{array}$ & & $\begin{array}{l}\mathrm{Tr} \\
\mathrm{Tr} \\
\mathrm{Tr}\end{array}$ & $\begin{array}{r}6 \\
53 \\
99\end{array}$ & $\begin{array}{l}94 \\
46 \\
\mathrm{Tr}_{\mathrm{r}}\end{array}$ & $\begin{array}{l}\mathrm{Tr} \\
\mathrm{Tr} \\
\mathrm{Tr}\end{array}$ & & & & & $\begin{array}{l}\mathrm{Tr} \\
\mathrm{Tr}\end{array}$ & & & & $\mathrm{Tr}$ & $\mathrm{P}$ & $\begin{array}{c}\mathrm{Tr} \\
9 \\
46\end{array}$ & $\begin{array}{r}5 \\
41 \\
53\end{array}$ & & $\begin{array}{c}19 \\
8 \\
\operatorname{Tr}\end{array}$ & $\begin{array}{l}75 \\
38 \\
\mathrm{Tr}\end{array}$ & & $\begin{array}{c}1.08 \\
1.3 \\
315 .\end{array}$ & $\begin{array}{l}5.5 \\
4.7 \\
1.1\end{array}$ & 15. \\
\hline $36-1,130$ & 10 & & & 100 & & $\mathrm{Tr}$ & 99 & $\mathrm{Tr}$ & Tr & & & & & & & & & $\mathrm{Tr}$ & $\mathrm{Tr}$ & 62 & 37 & & & $\mathrm{Tr}$ & & 200. & .6 & 150. \\
\hline $37-1,130$ & 13 & & & 100 & & $\mathrm{Tr}$ & 99 & $\mathrm{Tr}$ & Tr & & & & & & & & & & & 69 & 30 & & $\mathrm{Tr}$ & $\mathrm{Tr}_{\mathrm{r}}$ & & 75. & 4 & 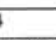 \\
\hline $38-1,90$ & 15 & $\mathrm{Tr}$ & & 99 & & $\mathrm{Tr}$ & 98 & $P$ & $\mathrm{Tr}$ & & & & & & & & & $\mathrm{Tr}$ & $\mathrm{Tr}$ & 78 & 20 & & $\mathrm{Tr}$ & $\mathrm{Tr}$ & & 20. & 3 & 100. \\
\hline $41-1,70$ & 35 & & & 100 & & & 100 & $\mathrm{Tr}$ & & & & & & & & & & & $\mathrm{Tr}$ & 79 & 20 & & $\mathrm{Tr}$ & $\mathrm{Tr}_{\mathrm{r}}$ & & 500. & 3 & 33. \\
\hline $\begin{array}{l}44-2,95 \\
44-3,90\end{array}$ & 35 & P & $\begin{array}{l}P \\
P\end{array}$ & $\begin{array}{l}97 \\
96\end{array}$ & & $\begin{array}{l}\mathrm{Tr} \\
\mathrm{Tr}\end{array}$ & $\begin{array}{l}97 \\
99\end{array}$ & \begin{tabular}{l|}
$\mathrm{P}$ \\
$\mathrm{P}$
\end{tabular} & $\begin{array}{l}\mathrm{Tr} \\
\mathrm{Tr}\end{array}$ & & & & & $\mathrm{Tr}$ & & & & $\begin{array}{l}\mathrm{Tr} \\
\mathrm{Tr}\end{array}$ & $\begin{array}{l}\mathrm{Tr} \\
\mathrm{P}\end{array}$ & $\begin{array}{l}72 \\
39\end{array}$ & $\begin{array}{l}24 \\
58\end{array}$ & & $\begin{array}{l}\mathrm{P} \\
\mathrm{P}\end{array}$ & & & & $\begin{array}{r}3 \\
1.5\end{array}$ & $\begin{array}{l}25 . \\
38 .\end{array}$ \\
\hline $45-1,70$ & 41 & $\mathrm{Tr}$ & $\mathrm{Tr}$ & 99 & & $\mathrm{Tr}$ & 100 & $\mathrm{Tr}$ & Tr & & & & & & & & & $\mathrm{Tr}$ & 4 & 48 & 47 & & $\mathrm{Tr}$ & & & & 1. & 12 . \\
\hline $47 \cdot 2,120$ & 35 & $P$ & $P$ & 97 & & $P$ & 98 & $\mathrm{Tr}$ & $\mathbf{P}$ & & & & & & & & & & 3 & 63 & 32 & & Tr & & & & 5 & 510. \\
\hline $50-1,75$ & 18 & $\mathrm{Tr}$ & & 100 & & $P$ & 99 & & Tr & $\mathrm{Tr}$ & & $\mathrm{Tr}$ & & $\mathrm{Tr}$ & & & & $\mathrm{Tr}$ & $P$ & 71 & 25 & & & & & & 4 & 14. \\
\hline 60 (Decant) & 10 & 5 & $P$ & 94 & & $\mathrm{Tr}$ & 100 & & $\mathrm{Tr}$ & & & & & & & & & & $P$ & 73 & 24 & & & & & & 3 & 310. \\
\hline $62, \mathrm{CC}$ (Decant) & 70 & $\mathrm{Tr}_{\mathrm{r}}$ & $\mathrm{Tr}$ & 99 & & & 100 & $\mathrm{Tr}$ & & & & & & & & & & & Tr & 96 & 4 & & $\mathrm{Tr}$ & & & & .04 & 46. \\
\hline $\begin{array}{l}\text { Site } 238 \\
1-1,75 \\
1-2,85 \\
1-3,85 \\
14,90 \\
1-5,75 \\
1-6,85 \\
1, \mathrm{CC}\end{array}$ & $\begin{array}{r}69 \\
71 \\
71 \\
51 \\
36 \\
7 \\
24\end{array}$ & & $\mathrm{Tr}$ & \begin{tabular}{r|}
100 \\
100 \\
99 \\
100 \\
100 \\
100 \\
100
\end{tabular} & & $\mathrm{Tr}$ & $\begin{array}{r}100 \\
98 \\
100 \\
79 \\
67 \\
73 \\
37\end{array}$ & $\begin{array}{l}\mathrm{P} \\
\mathrm{Tr} \\
21 \\
33 \\
28 \\
63\end{array}$ & $\mathrm{Tr}$ & & & & & & & & & $\mathrm{Tr}$ & $\begin{array}{l}\mathrm{Tr} \\
\mathrm{Tr} \\
\mathrm{Tr} \\
\mathrm{Tr} \\
\mathrm{Tr} \\
\mathrm{Tr}\end{array}$ & $\begin{array}{l}80 \\
39 \\
10 \\
30 \\
40 \\
54 \\
28\end{array}$ & $\begin{array}{r}20 \\
58 \\
90 \\
49 \\
27 \\
18 \\
9\end{array}$ & & $\begin{array}{l}\mathrm{Tr} \\
\mathrm{Tr} \\
\mathrm{Tr} \\
\mathrm{Tr}\end{array}$ & $\begin{array}{l}\mathrm{P} \\
\mathrm{Tr} \\
20 \\
27 \\
9 \\
52\end{array}$ & $\begin{array}{r}\mathrm{Tr} \\
7 \\
18 \\
11\end{array}$ & \begin{tabular}{|c}
50. \\
450. \\
4. \\
2.5 \\
8. \\
.7
\end{tabular} & $\begin{array}{r}3 \\
1.5 \\
9 . \\
1.7 \\
.7 \\
.3 \\
.3\end{array}$ & $\begin{array}{r}50 . \\
150 . \\
225 . \\
250 . \\
100 . \\
25 .\end{array}$ \\
\hline $\begin{array}{l}2-1,90 \\
2-2,85 \\
2-3,90 \\
24,105 \\
2-6,75 \\
2, \mathrm{CC}\end{array}$ & $\begin{array}{r}35 \\
39 \\
7 \\
74 \\
47 \\
40 \\
\end{array}$ & & & $\begin{array}{l}100 \\
100 \\
100 \\
100 \\
100 \\
100\end{array}$ & & $\mathrm{Tr}$ & $\begin{array}{l}\mathrm{P} \\
49 \\
65 \\
99 \\
92 \\
90\end{array}$ & \begin{tabular}{c|}
99 \\
51 \\
35 \\
$\mathrm{P}$ \\
8 \\
10
\end{tabular} & $\mathrm{Tr}$ & & & & & & & & & $\mathrm{Tr}$ & $\begin{array}{l}\mathrm{Tr} \\
\mathrm{Tr} \\
\mathrm{Tr} \\
\mathrm{Tr} \\
\mathrm{Tr}\end{array}$ & $\begin{array}{l}\mathrm{Tr} \\
39 \\
32 \\
74 \\
71 \\
34 \\
34\end{array}$ & $\begin{array}{l}\mathrm{Tr} \\
10 \\
32 \\
25 \\
21 \\
56\end{array}$ & & $\begin{array}{l}\mathrm{Tr} \\
\mathrm{Tr}\end{array}$ & $\begin{array}{r}9 \\
10 \\
32 \\
\mathrm{Tr} \\
7 \\
9\end{array}$ & \begin{tabular}{r|}
89 \\
39 \\
3 \\
$\mathrm{Tr}$ \\
$\mathrm{Tr}$
\end{tabular} & $\begin{array}{c}.1 \\
s . \\
2 . \\
100 . \\
13 . \\
10 .\end{array}$ & $\begin{array}{r}5 . \\
.3 \\
1 . \\
.3 \\
3 \\
1.7\end{array}$ & $\begin{array}{r}10 . \\
25 . \\
100 . \\
150 . \\
83 .\end{array}$ \\
\hline $\begin{array}{l}3-1,85 \\
3-3,85 \\
3-5,85\end{array}$ & $\begin{array}{l}35 \\
57\end{array}$ & & & $\begin{array}{l}100 \\
100 \\
100\end{array}$ & & $\mathrm{Tr}$ & $\begin{array}{l}83 \\
83 \\
82\end{array}$ & \begin{tabular}{l|}
17 \\
17 \\
18
\end{tabular} & $\mathrm{Tr}$ & & & & & & & & & & $\begin{array}{l}\mathrm{Tr} \\
\mathrm{Tr} \\
\mathrm{Tr}\end{array}$ & $\begin{array}{l}58 \\
66 \\
53\end{array}$ & $\begin{array}{l}25 \\
17 \\
29\end{array}$ & & $\begin{array}{l}\mathrm{Tr} \\
\mathrm{Tr}\end{array}$ & $\begin{array}{l}13 \\
13 \\
12\end{array}$ & \begin{tabular}{l|}
3 \\
3 \\
6
\end{tabular} & $\begin{array}{l}6.3 \\
6.3 \\
5 .\end{array}$ & $\begin{array}{l}.4 \\
.3 \\
.6\end{array}$ & $\begin{array}{r}75 . \\
50 . \\
250 .\end{array}$ \\
\hline
\end{tabular}




\begin{tabular}{|c|c|c|c|c|c|c|c|c|c|c|c|c|c|c|c|c|c|c|c|c|c|c|c|c|c|c|c|c|}
\hline $\begin{array}{l}\text { Core, Section } \\
\text { Top of } \\
\text { Interval } \\
\text { (cm) }\end{array}$ & 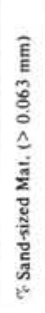 & 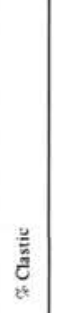 & 章 & 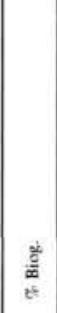 & $\frac{\vec{u}}{\underline{\underline{E}}}$ & 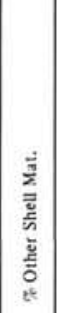 & 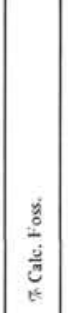 & 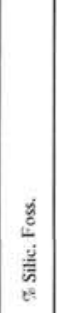 & $\frac{5}{2}$ & 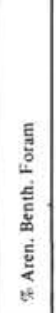 & 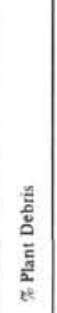 & 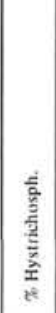 & 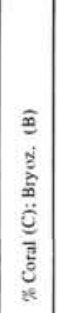 & 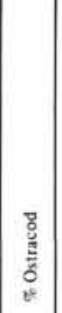 & 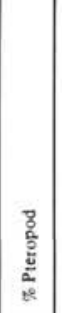 & 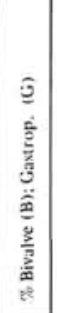 & 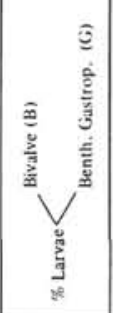 & $\frac{5}{\frac{5}{5}}$ & 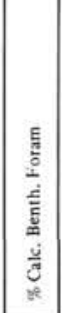 & 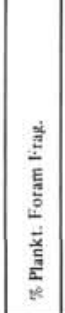 & 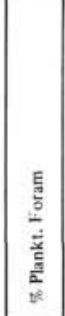 & 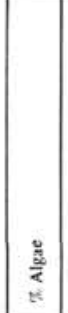 & 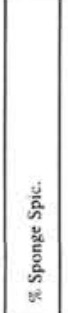 & 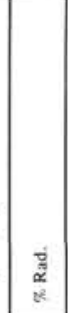 & 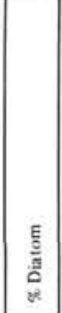 & 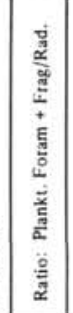 & 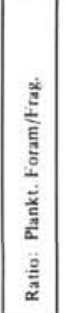 & 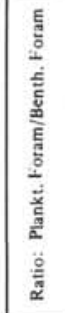 \\
\hline Site 238 & & & & & & & & & & & & & & & & & & & & & & & & & & & & \\
\hline $\begin{array}{l}4-1,85 \\
4-3,108 \\
4-5,84 \\
4, C C\end{array}$ & $\begin{array}{l}48 \\
47 \\
38 \\
36\end{array}$ & & & $\begin{array}{l}100 \\
100 \\
100 \\
100\end{array}$ & & $\begin{array}{l}\mathrm{Tr} \\
\mathrm{Tr} \\
\mathrm{Tr}\end{array}$ & $\begin{array}{l}80 \\
96 \\
91 \\
97\end{array}$ & $\begin{array}{r}11 \\
4 \\
9 \\
\mathbf{P}\end{array}$ & $\begin{array}{l}\mathrm{Tr} \\
\mathrm{Tr} \\
\mathrm{Tr}\end{array}$ & & & & & & & & & & $\begin{array}{l}\mathrm{Tr} \\
\mathrm{Tr} \\
\mathrm{Tr}\end{array}$ & $\begin{array}{l}36 \\
57 \\
76 \\
48\end{array}$ & $\begin{array}{l}53 \\
38 \\
15 \\
48\end{array}$ & & $\begin{array}{l}\mathrm{Tr} \\
\mathrm{Tr} \\
\mathrm{Tr}\end{array}$ & $\begin{array}{l}9 \\
4 \\
8 \\
P\end{array}$ & $\begin{array}{l}\mathrm{P} \\
\mathrm{Tr} \\
\mathrm{P} \\
\mathrm{T} t\end{array}$ & $\begin{array}{l}10 . \\
25 . \\
12 . \\
50 .\end{array}$ & $\begin{array}{r}1.5 \\
.7 \\
.3 \\
1 .\end{array}$ & $\begin{array}{l}300 . \\
200 \\
125 .\end{array}$ \\
\hline $\begin{array}{l}5-2,78 \\
5-4,23\end{array}$ & $\begin{array}{l}58 \\
48\end{array}$ & & & $\begin{array}{l}100 \\
100\end{array}$ & & & $\begin{array}{l}90 \\
27\end{array}$ & $\begin{array}{l}10 \\
73\end{array}$ & & & & & & & & & & & $\begin{array}{l}\mathrm{Tr} \\
\mathrm{Tr}\end{array}$ & $\begin{array}{l}63 \\
P\end{array}$ & $\begin{array}{l}27 \\
24\end{array}$ & & $\mathrm{Tr}$ & $\begin{array}{r}9 \\
24\end{array}$ & \begin{tabular}{l|}
$\mathrm{Tr}$ \\
48
\end{tabular} & \begin{tabular}{|c|}
10. \\
1.1
\end{tabular} & $10^{4}$ & $\begin{array}{r}75 . \\
100 .\end{array}$ \\
\hline $\begin{array}{l}6-1,90 \\
6-2,110 \\
6-4,85 \\
6, \mathrm{CC}\end{array}$ & $\begin{array}{l}34 \\
41 \\
31 \\
28\end{array}$ & $P$ & & $\begin{array}{l}100 \\
100 \\
100 \\
99\end{array}$ & & & $\begin{array}{l}83 \\
95 \\
75 \\
90\end{array}$ & \begin{tabular}{r|}
17 \\
5 \\
25 \\
10
\end{tabular} & & & & & & & & & & $\mathrm{Tr}$ & $\begin{array}{l}\mathrm{Tr} \\
\mathrm{Tr} \\
\mathrm{Tr} \\
\mathrm{Pr}\end{array}$ & $\begin{array}{l}69 \\
47 \\
50 \\
30\end{array}$ & $\begin{array}{l}14 \\
47 \\
25 \\
58 \\
\end{array}$ & & $\begin{array}{l}\mathrm{Tr} \\
\mathrm{Tr} \\
\mathrm{Tr} \\
\mathrm{Tr}\end{array}$ & $\begin{array}{r}14 \\
5 \\
12 \\
9\end{array}$ & \begin{tabular}{l|}
$\mathrm{P}$ \\
12
\end{tabular} & $\begin{array}{r}6 . \\
20 . \\
6 . \\
10 .\end{array}$ & $\begin{array}{l}.2 \\
1.5 \\
2 .\end{array}$ & $\begin{array}{c}100 . \\
200 \\
100 \\
40\end{array}$ \\
\hline $\begin{array}{l}7.3,80 \\
7.5,120 \\
7, C C\end{array}$ & $\begin{array}{l}39 \\
42 \\
38\end{array}$ & & & $\begin{array}{l}100 \\
100 \\
100\end{array}$ & & $\mathrm{Tr}$ & $\begin{array}{l}86 \\
90 \\
90\end{array}$ & \begin{tabular}{l|}
14 \\
10 \\
10
\end{tabular} & $\mathrm{Tr}$ & & & & & & & & & & $\begin{array}{l}\mathrm{Tr} \\
\mathrm{Tr} \\
\mathrm{Tr}\end{array}$ & $\begin{array}{l}55 \\
40 \\
30\end{array}$ & $\begin{array}{l}31 \\
50 \\
60\end{array}$ & & $\begin{array}{l}\mathrm{Tr} \\
\mathrm{Tr} \\
\mathrm{Tr}\end{array}$ & $\begin{array}{r}9 \\
10 \\
10\end{array}$ & 5 & $\begin{array}{l}9.2 \\
9 . \\
9 .\end{array}$ & $\begin{array}{l}.6 \\
1.3 \\
2 .\end{array}$ & $\begin{array}{l}200 . \\
125 . \\
150 .\end{array}$ \\
\hline $\begin{array}{l}8 \cdot 2,85 \\
8, \mathrm{CC}\end{array}$ & $\begin{array}{l}41 \\
40\end{array}$ & & & $\begin{array}{l}100 \\
100\end{array}$ & & $\mathrm{Tr}$ & $\begin{array}{l}94 \\
94\end{array}$ & $\begin{array}{l}6 \\
6\end{array}$ & $\mathrm{Tr}$ & & & & & & & & & & $\begin{array}{l}\mathrm{Tr} \\
\mathrm{Tr}\end{array}$ & $\begin{array}{l}60 \\
62\end{array}$ & $\begin{array}{l}35 \\
31\end{array}$ & & $\mathrm{Tr}$ & $\begin{array}{l}5 \\
6\end{array}$ & $\mathrm{Tr}$ & $\begin{array}{l}20 . \\
15 .\end{array}$ & $\begin{array}{l}.6 \\
.5\end{array}$ & $\begin{array}{l}5150 . \\
100 .\end{array}$ \\
\hline $\begin{array}{l}9 \cdot 1,35 \\
9, \mathrm{CC}\end{array}$ & $\begin{array}{l}39 \\
45\end{array}$ & & & $\begin{array}{l}100 \\
100\end{array}$ & & $\mathrm{Tr}$ & $\begin{array}{l}95 \\
94\end{array}$ & $\begin{array}{l}5 \\
6\end{array}$ & $\mathrm{Tr}$ & & & & & & & & & & $\begin{array}{l}\mathrm{Tr} \\
\mathrm{Tr}\end{array}$ & $\begin{array}{l}59 \\
47\end{array}$ & $\begin{array}{l}35 \\
47\end{array}$ & & $\begin{array}{l}\mathrm{Tr} \\
\mathrm{Tr}\end{array}$ & $\begin{array}{l}5 \\
6\end{array}$ & $\begin{array}{l}\mathrm{Tr} \\
\mathrm{Tr}\end{array}$ & $\begin{array}{l}20 . \\
17 .\end{array}$ & $1^{.6}$ & $\begin{array}{l}150 . \\
250 .\end{array}$ \\
\hline $\begin{array}{l}10-1,50 \\
10-3,78 \\
10-5,78 \\
10, \mathrm{cC}\end{array}$ & $\begin{array}{l}32 \\
35 \\
41 \\
28\end{array}$ & & & $\begin{array}{l}100 \\
100 \\
100 \\
100\end{array}$ & & $\mathrm{Tr}$ & $\begin{array}{l}98 \\
96 \\
98 \\
98\end{array}$ & \begin{tabular}{l|}
$\mathrm{P}$ \\
${ }^{4}$ \\
$\mathrm{P}$ \\
$\mathrm{P}$
\end{tabular} & $\mathrm{Tr}$ & & & & & & & & & $\mathrm{T}_{\mathrm{r}}$ & $\begin{array}{l}\mathrm{Tr} \\
\mathrm{Tr} \\
\mathrm{Tr}\end{array}$ & $\begin{array}{l}59 \\
64 \\
39 \\
49\end{array}$ & $\begin{array}{l}39 \\
32 \\
58 \\
48\end{array}$ & & $\begin{array}{l}\mathrm{Tr} \\
\mathrm{Tr}\end{array}$ & $\begin{array}{l}\mathrm{P}^{\mathrm{P}} \\
{ }^{4} \mathrm{P}^{\mathrm{P}} \\
\mathrm{P}\end{array}$ & $\mathrm{Tr}$ & $\begin{array}{l}50 . \\
20 . \\
50 . \\
50 .\end{array}$ & $\begin{array}{l}.7 \\
\text { is } \\
\text { i.s } \\
1 .\end{array}$ & $\begin{array}{l}200 . \\
300 . \\
250 .\end{array}$ \\
\hline $\begin{array}{l}111-1,69 \\
11-3,84 \\
11-5,100 \\
11, c c\end{array}$ & $\begin{array}{l}37 \\
33 \\
37 \\
32\end{array}$ & & & $\begin{array}{l}100 \\
100 \\
100 \\
100\end{array}$ & & $\begin{array}{l}\mathrm{Tr} \\
\mathrm{Tr}\end{array}$ & $\begin{array}{l}82 \\
90 \\
92 \\
99\end{array}$ & $\begin{array}{l}18 \\
10 \\
7 \\
P\end{array}$ & $\mathrm{Tr}$ & & & & & & & & & $\mathrm{Tr}$ & $\begin{array}{l}\mathrm{Tr} \\
\mathrm{Tr} \\
\mathrm{Tr}\end{array}$ & $\begin{array}{l}33 \\
36 \\
37 \\
29\end{array}$ & $\begin{array}{l}49 \\
54 \\
55 \\
69\end{array}$ & & $\mathrm{Tr}$ & $\begin{array}{r}16 \\
9 \\
6 \\
\mathrm{Tr}\end{array}$ & $\begin{array}{l}\mathrm{P} \\
\mathrm{Tr} \\
\mathrm{P}\end{array}$ & $\begin{array}{c}10 . \\
17 . \\
100 .\end{array}$ & $\begin{array}{l}1.5 \\
1.5 \\
1.5 \\
2.3\end{array}$ & $\begin{array}{l}500 . \\
500 . \\
5175 .\end{array}$ \\
\hline $\begin{array}{l}12-1,85 \\
12-3,85 \\
12-5,80 \\
12, c \mathrm{cc}\end{array}$ & $\begin{array}{l}33 \\
33 \\
22 \\
24\end{array}$ & & & $\begin{array}{l}100 \\
100 \\
100 \\
100\end{array}$ & & $\mathrm{Tr}$ & $\begin{array}{l}95 \\
88 \\
82 \\
95\end{array}$ & $\begin{array}{r}4 \\
12 \\
18 \\
5\end{array}$ & Tr & & & & & & & & & $\mathrm{Tr}$ & $\begin{array}{l}\mathrm{P} \\
\mathrm{Tr} \\
\mathrm{Tr} \\
\mathrm{Tr}\end{array}$ & $\begin{array}{l}11 \\
52 \\
16 \\
16\end{array}$ & $\begin{array}{l}52 \\
35 \\
66 \\
79\end{array}$ & & $\begin{array}{l}\mathrm{Tr} \\
\mathrm{Tr} \\
\mathrm{Tr}\end{array}$ & $\begin{array}{r}4 \\
9 \\
16 \\
5\end{array}$ & $\begin{array}{l}4 \\
\mathrm{Tr} \\
\mathrm{Tr}\end{array}$ & \begin{tabular}{|c|}
23. \\
10. \\
5. \\
20.
\end{tabular} & $\begin{array}{l}1.3 \\
4.7 \\
5 .\end{array}$ & $\begin{array}{c}25 . \\
200 . \\
400 . \\
500 .\end{array}$ \\
\hline $\begin{array}{l}13-1,50 \\
13-2,85 \\
13-3,85 \\
13-5,85 \\
13, \mathrm{CC}\end{array}$ & $\begin{array}{l}20 \\
20 \\
16 \\
28\end{array}$ & & & $\begin{array}{l}100 \\
100 \\
100 \\
100 \\
100\end{array}$ & & $\begin{array}{l}\mathrm{Tr} \\
\mathrm{Tr}\end{array}$ & $\begin{array}{l}95 \\
90 \\
94 \\
82 \\
96\end{array}$ & \begin{tabular}{r|}
5 \\
10 \\
6 \\
18 \\
$P$
\end{tabular} & $\mathrm{Tr}$ & & & & & $\mathrm{Tr}$ & & & & & $\begin{array}{l}\mathrm{Tr} \\
\mathrm{Tr} \\
\mathrm{P}\end{array}$ & $\begin{array}{l}32 \\
20 \\
39 \\
57 \\
19\end{array}$ & $\begin{array}{l}63 \\
70 \\
55 \\
24 \\
79\end{array}$ & & $\mathrm{Tr}$ & $\begin{array}{c}4 \\
10 \\
6 \\
16 \\
P\end{array}$ & P & $\begin{array}{l}23 . \\
9 . \\
15 . \\
5 . \\
25 .\end{array}$ & $\begin{array}{l}2 . \\
3.5 \\
1.4 \\
.4 \\
4 .\end{array}$ & $\begin{array}{r}300 . \\
350 . \\
15 .\end{array}$ \\
\hline $\begin{array}{l}14-1,85 \\
14-2,65 \\
14-3,85 \\
14-5,85 \\
14, \propto C\end{array}$ & $\begin{array}{l}54 \\
67 \\
79 \\
73 \\
45\end{array}$ & & & $\begin{array}{l}100 \\
100 \\
100 \\
100 \\
100 \\
\end{array}$ & & $\mathrm{Tr}$ & $\begin{array}{r}100 \\
100 \\
100 \\
100 \\
99\end{array}$ & $\mathrm{Tr}$ & $\mathrm{Tr}$ & & & & & & & & & & $\begin{array}{l}\mathrm{Tr} \\
\mathrm{Tr} \\
\mathrm{Tr}\end{array}$ & $\begin{array}{r}75 \\
62 \\
9 \\
91 \\
9\end{array}$ & $\begin{array}{l}25 \\
37 \\
91 \\
9 \\
90\end{array}$ & & Tr & $\mathrm{Tr}$ & & 110. & $\begin{array}{r}.3 \\
.6 \\
10 . \\
10 . \\
1 .\end{array}$ & $\begin{array}{l}150 . \\
500 \\
500 .\end{array}$ \\
\hline $\begin{array}{l}15-1,85 \\
15-3,85 \\
15-5,90 \\
15, \propto C\end{array}$ & $\begin{array}{r}8 \\
27 \\
25 \\
29\end{array}$ & & & $\begin{array}{l}100 \\
100 \\
100 \\
100\end{array}$ & & $\begin{array}{l}\mathrm{Tr} \\
\mathrm{Tr}\end{array}$ & $\begin{array}{l}91 \\
89 \\
99 \\
99\end{array}$ & $\begin{array}{r}9 \\
11 \\
\mathrm{Tr} \\
\mathrm{P}\end{array}$ & $\mathrm{Tr}$ & Tr & & & & $\mathrm{Tr}$ & & & & $\mathrm{Tr}$ & $\begin{array}{l}\mathrm{Tr} \\
\mathrm{Tr} \\
\mathrm{Tr} \\
\mathrm{Tr}\end{array}$ & $\begin{array}{l}36 \\
44 \\
20 \\
49\end{array}$ & $\begin{array}{l}54 \\
44 \\
79 \\
49\end{array}$ & & $\begin{array}{l}\mathrm{Tr} \\
\mathrm{Tr} \\
\mathrm{Tr}\end{array}$ & $\begin{array}{r}99 \\
11 \\
\mathrm{Tr} \\
\mathrm{Tr}\end{array}$ & & $\begin{array}{r}10 . \\
8 . \\
17 . \\
100\end{array}$ & $\begin{array}{l}1.5 \\
1 . \\
4 . \\
1 .\end{array}$ & $\begin{array}{l}300 . \\
200 . \\
400 \\
250\end{array}$ \\
\hline $\begin{array}{l}16-1,85 \\
16-3,20 \\
16-5,85 \\
16, \mathrm{cC}\end{array}$ & $\begin{array}{l}23 \\
28 \\
42\end{array}$ & & & $\begin{array}{l}100 \\
100 \\
100 \\
100\end{array}$ & & $\begin{array}{l}\mathrm{Tr} \\
\mathrm{Tr} \\
\mathrm{Tr}\end{array}$ & $\begin{array}{r}91 \\
92 \\
100 \\
99\end{array}$ & $\begin{array}{r}9 \\
8 \\
P\end{array}$ & $\begin{array}{l}\mathrm{Tr} \\
\mathrm{Tr} \\
\mathrm{Tr}\end{array}$ & & & & & & & & & $\mathrm{Tr}$ & $\begin{array}{l}\mathrm{Tr} \\
\mathrm{Tr} \\
\mathrm{Tr}\end{array}$ & $\begin{array}{l}76 \\
46 \\
60 \\
37\end{array}$ & $\begin{array}{l}15 \\
46 \\
40 \\
61\end{array}$ & & Tr & $\begin{array}{c}8 \\
7 \\
\mathrm{Tr}\end{array}$ & $\begin{array}{l}\mathrm{P} \\
\mathrm{Tr}\end{array}$ & $\begin{array}{c}12 . \\
13 . \\
100\end{array}$ & $\begin{array}{l}.2 \\
1.7 \\
1.7\end{array}$ & $\begin{array}{l}100 . \\
100 \\
25 .\end{array}$ \\
\hline $\begin{array}{l}17-1,85 \\
17-3,85 \\
17.5,85 \\
17, \mathrm{cC}\end{array}$ & $\begin{array}{l}17 \\
29 \\
21\end{array}$ & & & $\begin{array}{l}100 \\
100 \\
100 \\
100\end{array}$ & $\mathrm{Tr}$ & $\begin{array}{l}\mathrm{Tr} \\
\mathrm{Tr} \\
\mathrm{Tr}\end{array}$ & $\begin{array}{l}97 \\
88 \\
93 \\
88\end{array}$ & \begin{tabular}{r|}
$p$ \\
11 \\
7 \\
11
\end{tabular} & $\begin{array}{l}\mathrm{Tr} \\
\mathrm{Tr} \\
\mathrm{Tr}\end{array}$ & $\mathrm{Tr}$ & & & & & & & & $\mathrm{Tr}$ & $\begin{array}{l}\mathrm{Tr} \\
\mathrm{Tr} \\
\mathrm{Tr}\end{array}$ & $\begin{array}{l}39 \\
66 \\
62 \\
55\end{array}$ & $\begin{array}{l}58 \\
22 \\
31 \\
33\end{array}$ & & Tr & 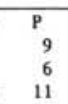 & $\begin{array}{l}\mathrm{Tr} \\
\mathrm{P} \\
\mathrm{Tr}\end{array}$ & $\begin{array}{l}50 . \\
10 . \\
15 . \\
8 .\end{array}$ & $\begin{array}{l}1.5 \\
.3 \\
5 \\
.6\end{array}$ & $\begin{array}{c}300 \\
50 . \\
150 .\end{array}$ \\
\hline $\begin{array}{l}18-2,85 \\
18-5,85 \\
18, \subset C\end{array}$ & 12 & & & $\begin{array}{l}100 \\
100 \\
100\end{array}$ & $\pi$ & $\begin{array}{l}\mathrm{Tr} \\
\mathrm{Tr}\end{array}$ & $\begin{array}{l}97 \\
96 \\
96\end{array}$ & \begin{tabular}{r|}
$\mathrm{P}$ \\
4 \\
4
\end{tabular} & $\mathrm{Tr}$ & & & & & $\begin{array}{l}\mathrm{Tr} \\
\mathrm{Tr}\end{array}$ & & & & & $\begin{array}{l}\mathrm{Tr} \\
\mathrm{Tr} \\
\mathrm{Tr}\end{array}$ & $\begin{array}{l}24 \\
43 \\
26\end{array}$ & $\begin{array}{l}72 \\
53 \\
69\end{array}$ & & $\begin{array}{l}\mathrm{Tr} \\
\mathrm{Tr} \\
\mathrm{Tr}\end{array}$ & $\begin{array}{l} \\
3 \\
4\end{array}$ & $\mathrm{Tr}$ & $\begin{array}{l}40 . \\
30 . \\
28 .\end{array}$ & $\begin{array}{l}3.3 \\
1.3 \\
2.7\end{array}$ & $\begin{array}{l}100 \\
250 \\
200\end{array}$ \\
\hline $\begin{array}{l}19 \cdot 2,88 \\
19-5,85 \\
19, \mathrm{CC}\end{array}$ & $\begin{array}{l}24 \\
24\end{array}$ & $\mathrm{Tr}$ & & $\begin{array}{l}100 \\
100 \\
100\end{array}$ & & & $\begin{array}{r}95 \\
89 \\
100\end{array}$ & \begin{tabular}{r|}
5 \\
11
\end{tabular} & & & & & & & & & & $\mathrm{Tr}$ & $\begin{array}{l}\mathrm{Tr} \\
\mathrm{Tr}\end{array}$ & $\begin{array}{c}47 \\
36 \\
9\end{array}$ & $\begin{array}{l}47 \\
54 \\
90\end{array}$ & & Tr & $\begin{array}{l}5 \\
9\end{array}$ & P & $\begin{array}{l}20 . \\
10 .\end{array}$ & $\begin{array}{l}1 . \\
1.5 \\
10 .\end{array}$ & $\begin{array}{r}67 . \\
250 .\end{array}$ \\
\hline $\begin{array}{l}20-2,85 \\
20-5,85 \\
20,0 \mathrm{C}\end{array}$ & $\begin{array}{l}35 \\
21 \\
30\end{array}$ & & & $\begin{array}{l}100 \\
100 \\
100\end{array}$ & & $\begin{array}{l}\mathrm{Tr} \\
\mathrm{Tr}\end{array}$ & $\begin{array}{l}98 \\
98 \\
99\end{array}$ & $\begin{array}{l}\mathrm{P}^{2} \\
\mathrm{Tr}\end{array}$ & $\begin{array}{l}\mathrm{Tr} \\
\mathrm{Tr}\end{array}$ & $\mathrm{Tr}$ & & & & & & & & $\mathrm{Tr}$ & $\begin{array}{l}\mathrm{Tr} \\
\mathrm{Tr} \\
\mathrm{Tr}\end{array}$ & $\begin{array}{l}24 \\
24 \\
44\end{array}$ & $\begin{array}{l}73 \\
73 \\
55\end{array}$ & & $\begin{array}{l}\mathrm{Tr} \\
\mathrm{Tr}\end{array}$ & $\begin{array}{l}\mathrm{P} \\
\mathrm{P} \\
\mathrm{Tr}\end{array}$ & & \begin{tabular}{|c|}
44. \\
80. \\
225.
\end{tabular} & $\begin{array}{l}3 . \\
3 . \\
1.3\end{array}$ & $\begin{array}{c}150 . \\
150 . \\
83 .\end{array}$ \\
\hline $\begin{array}{l}21-2,85 \\
21-5,85 \\
21, C C\end{array}$ & $\begin{array}{l}34 \\
20\end{array}$ & & & $\begin{array}{l}100 \\
100 \\
100\end{array}$ & & $\begin{array}{l}\mathrm{Tr} \\
\mathrm{Tr}\end{array}$ & $\begin{array}{l}99 \\
78 \\
80\end{array}$ & \begin{tabular}{l|}
$\mathrm{P}$ \\
22 \\
20
\end{tabular} & $\begin{array}{l}\mathrm{Tr} \\
\mathrm{Tr}\end{array}$ & & & & & & & & & & $\begin{array}{l}\mathrm{Tr} \\
\mathrm{Tr}\end{array}$ & $\begin{array}{l}39 \\
50 \\
45\end{array}$ & $\begin{array}{l}59 \\
29 \\
34\end{array}$ & & $\begin{array}{l}\mathrm{Tr} \\
\mathrm{Tr}\end{array}$ & $\begin{array}{l}\mathrm{Tr} \\
20 \\
20\end{array}$ & $\mathbf{P}$ & $\begin{array}{c}100 \\
3.5 \\
4 .\end{array}$ & $\begin{array}{r}1.5 \\
.6 \\
.8\end{array}$ & $\begin{array}{r}150 . \\
40 .\end{array}$ \\
\hline $\begin{array}{l}22-2,95 \\
22-5,85 \\
22, \mathrm{CC}\end{array}$ & $\begin{array}{l}18 \\
28\end{array}$ & & & $\begin{array}{l}100 \\
100 \\
100\end{array}$ & & $\begin{array}{l}\mathrm{Tr} \\
\mathrm{Tr}\end{array}$ & $\begin{array}{l}90 \\
94 \\
97\end{array}$ & $\begin{array}{l}10 \\
p^{6}\end{array}$ & $\begin{array}{l}\mathrm{Tr} \\
\mathrm{Tr}\end{array}$ & & & & & $\mathrm{Tr}$ & & & & & $\begin{array}{l}\mathrm{Tr} \\
\mathrm{Tr} \\
\mathrm{Tr}\end{array}$ & $\begin{array}{r}59 \\
28 \\
9\end{array}$ & $\begin{array}{l}30 \\
66 \\
87\end{array}$ & & $\begin{array}{l}\mathrm{Tr} \\
\mathrm{Tr}\end{array}$ & $\begin{array}{l}10 \\
6 \\
p\end{array}$ & $\mathrm{Tr}$ & $\begin{array}{l}9 . \\
17 . \\
37 .\end{array}$ & $\begin{array}{r}.5 \\
2.3 \\
10 .\end{array}$ & $\begin{array}{c}75 . \\
117 . \\
167 .\end{array}$ \\
\hline $\begin{array}{l}23-2,90 \\
23-5,85 \\
23, \propto C\end{array}$ & $\begin{array}{l}21 \\
18\end{array}$ & & $\mathrm{Tr}$ & $\begin{array}{l}100 \\
100 \\
100\end{array}$ & & $\begin{array}{l}\mathrm{Tr} \\
\mathrm{Tr}\end{array}$ & $\begin{array}{l}94 \\
80 \\
98\end{array}$ & $\begin{array}{r}6 \\
20 \\
2\end{array}$ & - ${ }_{\mathrm{Tr}}^{\mathrm{Tr}}$ & & & & & & & & & & $\begin{array}{l}\mathrm{Tr} \\
\mathrm{Tr}\end{array}$ & $\begin{array}{l}66 \\
40 \\
36\end{array}$ & $\begin{array}{l}28 \\
40 \\
62\end{array}$ & & $\mathbf{T r}$ & $\begin{array}{l}6 \\
20 \\
P\end{array}$ & $\begin{array}{l}\mathrm{Tr} \\
\mathrm{Tr}\end{array}$ & $\begin{array}{c}17 . \\
4 . \\
55 .\end{array}$ & $\begin{array}{l}{ }^{4} \\
1 . \\
1.8\end{array}$ & $\begin{array}{l}200 . \\
175 .\end{array}$ \\
\hline $\begin{array}{l}24-2,84 \\
24-5,85 \\
24, \propto C\end{array}$ & $\begin{array}{l}10 \\
38\end{array}$ & & $\mathrm{Tr}_{\mathrm{r}}$ & $\begin{array}{l}100 \\
100 \\
100\end{array}$ & & & $\begin{array}{l}100 \\
100 \\
100\end{array}$ & $\begin{array}{l}\mathrm{Tr} \\
\mathrm{Tr}\end{array}$ & & & & & & & & & & & $\begin{array}{l}\mathrm{Tr} \\
\mathrm{Tr} \\
\mathrm{Tr}\end{array}$ & $\begin{array}{r}20 \\
30 \\
9\end{array}$ & $\begin{array}{l}80 \\
70 \\
91\end{array}$ & & $\mathrm{Tr}$ & $\mathbf{T r}$ & & 500. & $\begin{array}{c}4 . \\
2.3 \\
10 .\end{array}$ & $\begin{array}{l}400 . \\
350 . \\
500 .\end{array}$ \\
\hline
\end{tabular}




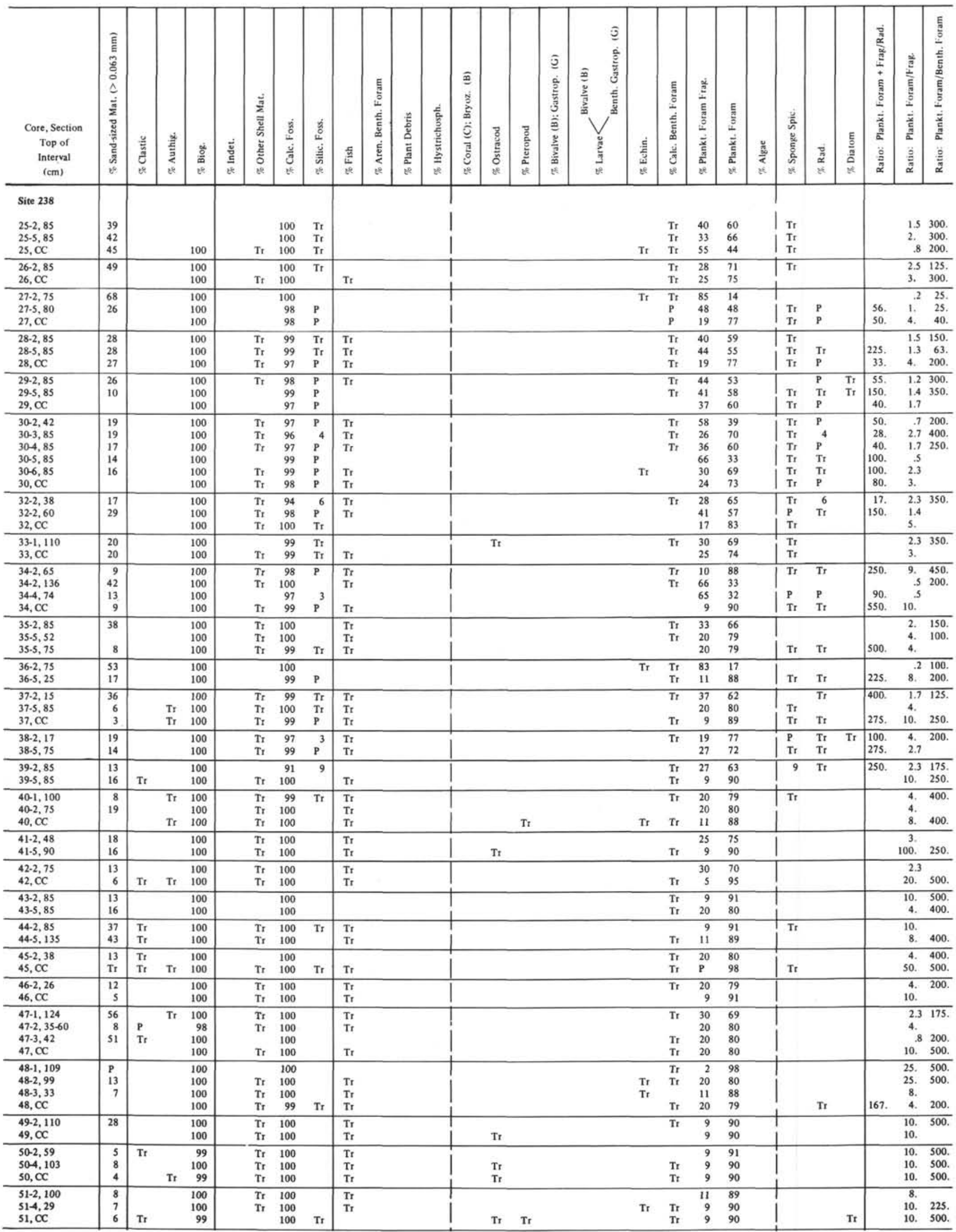




\section{J. THIEDE}

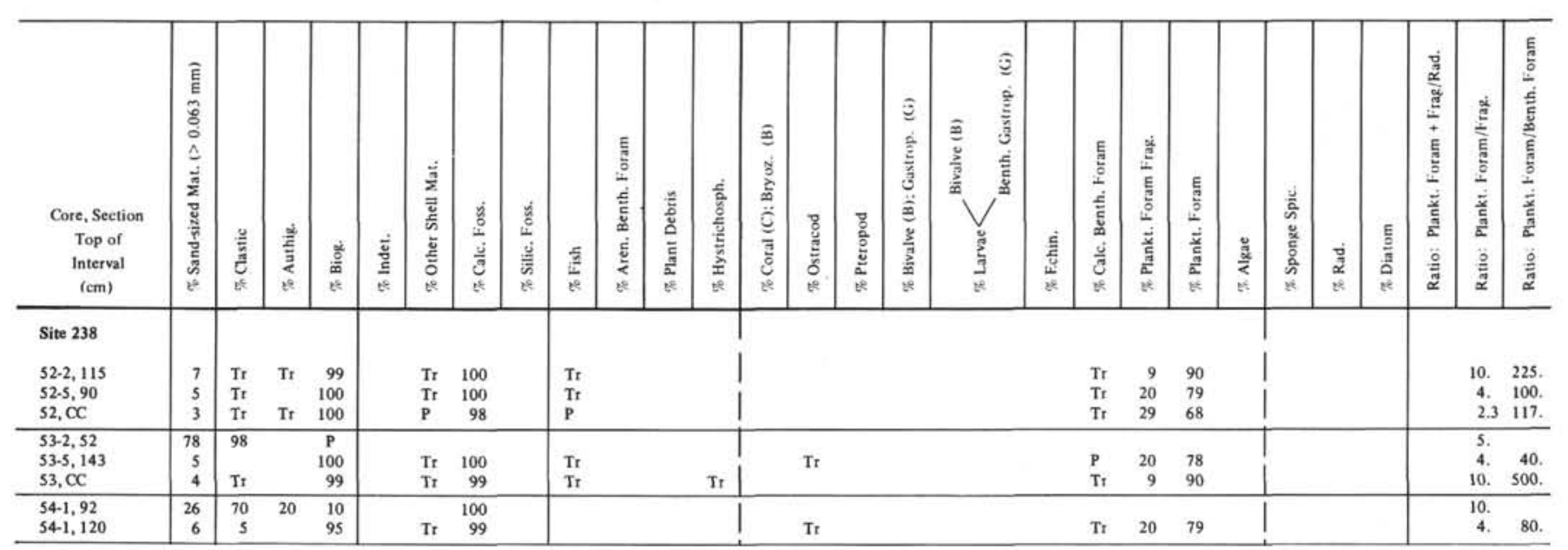


APPENDIX

Smear Slide Data, Leg 24

\begin{tabular}{|c|c|c|c|c|c|c|c|c|c|c|c|c|c|}
\hline $\begin{array}{c}\text { Core, Section } \\
\text { Top of } \\
\text { Interval } \\
(\mathrm{cm})\end{array}$ & 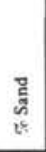 & $\begin{array}{l}\overrightarrow{\bar{F}} \\
\text { है }\end{array}$ & 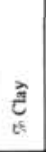 & 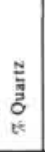 & 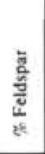 & $\sum_{\text {E }}^{g}$ & 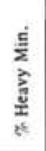 & 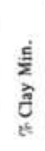 & 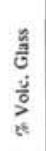 & 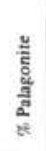 & 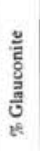 & 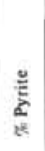 & 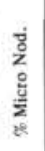 \\
\hline Site 231 & & & & & & & & & & & & & \\
\hline $1-1,115$ & 5 & 40 & s5 & 2 & 1 & & 1 & & 2 & & & & \\
\hline $2 \cdot 2,72$ & 6 & 30 & 65 & 2 & 1 & 1 & $i$ & & 2 & & & & \\
\hline 2,00 & 5 & 45 & so & 5 & 2 & 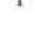 & 2 & & 1 & & & 1 & \\
\hline $3-2,80$ & 10 & 30 & 60 & 5 & & 1 & 1 & & 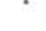 & & 1 & 1 & \\
\hline 34,120 & $\begin{array}{l}100 \\
50\end{array}$ & 25 & 25 & 50 & 1 & 1 & 1 & & & & 1 & 2 & \\
\hline 34,140 & 30 & 35 & 35 & 5 & 1 & 1 & 1 & & & & & $i$ & \\
\hline $4-2,54$ & 40 & 30 & 30 & 10 & & i & i & & & & & i & \\
\hline $1-2,120$ & 5 & 40 & s5 & 5 & & 1 & 2 & & & & & 1 & \\
\hline $5-1,95$ & 5 & 40 & 55 & 5 & & 2 & $i$ & & 2 & & & 2 & \\
\hline $5.2,120$ & 5 & 45 & so & 2 & & & & & & & & 2 & \\
\hline $5.2,145$ & 70 & 45 & 45 & 20 & 5 & 2 & 5 & & & & & & \\
\hline $5.3,90$ & 50 & 25 & 25 & 10 & 2 & & 5 & & & & & & \\
\hline $5-5,80$ & 5 & 20 & 75 & 5 & & & 1 & & & & & & \\
\hline $6-1,105$ & 30 & 30 & 40 & 10 & & 1 & 1 & & & & & 2 & \\
\hline $6-2,100$ & 60 & 20 & 20 & 5 & 2 & & 2 & & & & & & \\
\hline $6 \cdot 2,147$ & 10 & 40 & 50 & 10 & & & 2 & & & & & 2 & \\
\hline 64,100 & 2 & 40 & 50 & 1 & & 2 & & & & & & $i$ & \\
\hline $7.3,80$ & 5 & 40 & 55 & 2 & & 1 & 1 & & & & & i & \\
\hline $7-3,102$ & 60 & 20 & 20 & 5 & & $x^{\prime}$ & 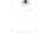 & & & & & 5 & \\
\hline $8-1,80$ & 10 & 40 & 50 & 5 & 2 & 1 & 1 & & & & & 2 & \\
\hline $8-2,80$ & 5 & 40 & 50 & 1 & 2 & I & . & & & & & $i$ & \\
\hline $8-3,80$ & 5 & 45 & 50 & 2 & 1 & 1 & 1 & & & & & 1 & \\
\hline 84,91 & 40 & 30 & 30 & 5 & 2 & 1 & 1 & & & & & 5 & \\
\hline $8-5,35$ & 40 & 40 & $\begin{array}{l}30 \\
30\end{array}$ & 20 & 5 & & 1 & & & & & 5 & \\
\hline $9-2,90$ & 5 & 40 & s5 & 5 & 1 & & & & & & & 2 & \\
\hline $9-5,90$ & 3 & 45 & 52 & 5 & 2 & 2 & & & & & & 2 & \\
\hline $10-1,100$ & 3 & 40 & 57 & 2 & & & & & & & & & \\
\hline $10-4,80$ & 3 & 35 & 62 & 5 & 1 & & & & & & & 1 & \\
\hline $11-3,80$ & 5 & 45 & so & 10 & i & 2 & & & & & & 2 & \\
\hline $12-2,80$ & 5 & 40 & 55 & 20 & 1 & & 2 & & 1 & & & 1 & \\
\hline $12-4,40$ & 5 & 20 & 75 & 20 & & & 5 & & 2 & & & 2 & \\
\hline $13.3,80$ & 5 & 25 & 70 & 20 & 2 & & & & & & & & \\
\hline $14-2,80$ & 2 & 28 & 70 & 5 & & & 1 & & & & & 1 & \\
\hline $14-4,80$ & 5 & 20 & 75 & 5 & & & & & & & & 2 & \\
\hline $15-1,90$ & 5 & 25 & 70 & 20 & 5 & & 5 & & 5 & & & 2 & \\
\hline $15-3,20$ & 40 & 30 & 30 & 10 & 2 & & 2 & & & & & & \\
\hline $14-4,80$ & 3 & 27 & 70 & 5 & & 1 & & & 2 & & & 5 & \\
\hline $17-1,100$ & 3 & 27 & 70 & 20 & 5 & & 2 & & & & & 5 & \\
\hline $17-2,100$ & 25 & 40 & 35 & 10 & & & 1 & & & & & & \\
\hline $18-2,80$ & 5 & 35 & 60 & 5 & & & i & & & & & 2 & \\
\hline $19 \cdot 2,44$ & 30 & 35 & 35 & 10 & $s$ & & 5 & & & & & & \\
\hline $19-3,90$ & 5 & 35 & 60 & 5 & 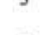 & 1 & $i$ & & & & & 1 & \\
\hline $20-2,31$ & 50 & 25 & 25 & 1 & 5 & 1 & 1 & & 90 & & & 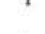 & \\
\hline $20-3,30$ & 5 & 35 & 60 & 2 & 2 & & 1 & & & & & 1 & \\
\hline $21-2,22$ & so & 30 & ${ }_{20}^{20}$ & 2 & 2 & & 1 & & 95 & & & 1 & \\
\hline $21-2,108$ & 40 & 30 & 30 & so & 10 & & 2 & & & & & 5 & \\
\hline $21-4,100$ & 5 & 35 & 60 & 5 & 2 & 1 & & & 1 & & & 1 & \\
\hline $22-1,88$ & 60 & 25 & 15 & 3 & 2 & & 1 & & 95 & & & & \\
\hline $22-5,40$ & 5 & 25 & 70 & 2 & 2 & & & & 2 & & & & \\
\hline $23-5,19$ & 5 & 60 & 35 & 2 & 2 & & & 90 & & & & & \\
\hline $24-2,10$ & 30 & 40 & 30 & 20 & 10 & & 2 & & & & & 1 & \\
\hline $24-4,100$ & 5 & 40 & 60 & 5 & 2 & & 2 & & & & & 2 & \\
\hline $25-4,100$ & 5 & 30 & 65 & 2 & 1 & & & & & & & 2 & \\
\hline $26-4,75$ & 40 & 30 & 30 & 30 & 5 & & & & & & & 5 & \\
\hline $28-4,80$ & 2 & 45 & 53 & 1 & 1 & & & & & & & & \\
\hline $29-4,100$ & 5 & 45 & 50 & 5 & 2 & & 1 & & & & & 1 & \\
\hline $30-3,96$ & 10 & 40 & 50 & 2 & 1 & & i & & 1 & & & 2 & \\
\hline $31-4,100$ & 5 & 30 & 65 & 1 & i & 1 & i & & & & & 2 & \\
\hline $32-4,80$ & 5 & 45 & 50 & i & i & i & & & & & & $i$ & \\
\hline $33-5,100$ & 2 & 25 & 70 & i & & i & 1 & & & & & i & \\
\hline $34-4,100$ & 5 & 25 & 70 & 2 & & & 2 & & 1 & & & & \\
\hline $35-2,80$ & 5 & 25 & 70 & 2 & 2 & & 1 & & 1 & & & 1 & \\
\hline $36-2,110$ & 3 & 30 & 70 & & & & $i$ & & & & & 1 & \\
\hline $37-3,73$ & 2 & 25 & 70 & 1 & 1 & & 1 & & 1 & & & 2 & \\
\hline $38-3,100$ & 5 & 25 & 70 & 2 & 1 & & 1 & & 1 & & & 2 & \\
\hline $39-3,100$ & i & 30 & 70 & 2 & & 1 & 2 & & $i$ & & & 2 & \\
\hline $40-2,80$ & 5 & 30 & 65 & 2 & 1 & & i & & & & & $i$ & \\
\hline $41-3,100$ & 3 & 27 & 70 & 2 & 1 & & 1 & & & & & 2 & \\
\hline $42-5,100$ & 2 & 28 & 70 & 1 & & & 1 & & & & & 1 & \\
\hline $43-5,100$ & 3 & 30 & 65 & 2 & & 1 & & & & & & 1 & \\
\hline 441,90 & 5 & 30 & 65 & 5 & 2 & & 1 & & 1 & 10 & & 5 & \\
\hline $45-3,120$ & 2 & 20 & 75 & & 1 & & 1 & & & & & & \\
\hline $46-6,90$ & 40 & 30 & 30 & 30 & 5 & & 1 & & & & & 2 & \\
\hline $47 \cdot 3,100$ & 3 & 27 & 70 & 1 & & & 1 & & & & & 1 & \\
\hline $48-3,80$ & 2 & 20 & 75 & i & & 1 & & & & & & i & \\
\hline $50-1,97$ & 30 & 40 & 30 & 15 & 5 & 1 & 3 & & & & & 2 & \\
\hline $50-3,100$ & 3 & 47 & 80 & 2 & 1 & & & & 1 & & & & \\
\hline $51-6,50$ & 30 & 35 & 35 & 20 & 5 & 1 & 3 & & & & & 5 & \\
\hline $52-3,80$ & 3 & 27 & 70 & 2 & & & 1 & & 1 & & & 1 & \\
\hline $53-3,80$ & 2 & 23 & 75 & 1 & & & i & & $i$ & & & i & \\
\hline $54-2,100$ & 2 & 28 & 70 & 1 & & & 1 & & & & & 1 & \\
\hline $55-2,80$ & 5 & 40 & 60 & 2 & & & 1 & & 1 & & & 1 & \\
\hline $56-3,90$ & 3 & so & so & & & 1 & 1 & & & & & 1 & \\
\hline
\end{tabular}




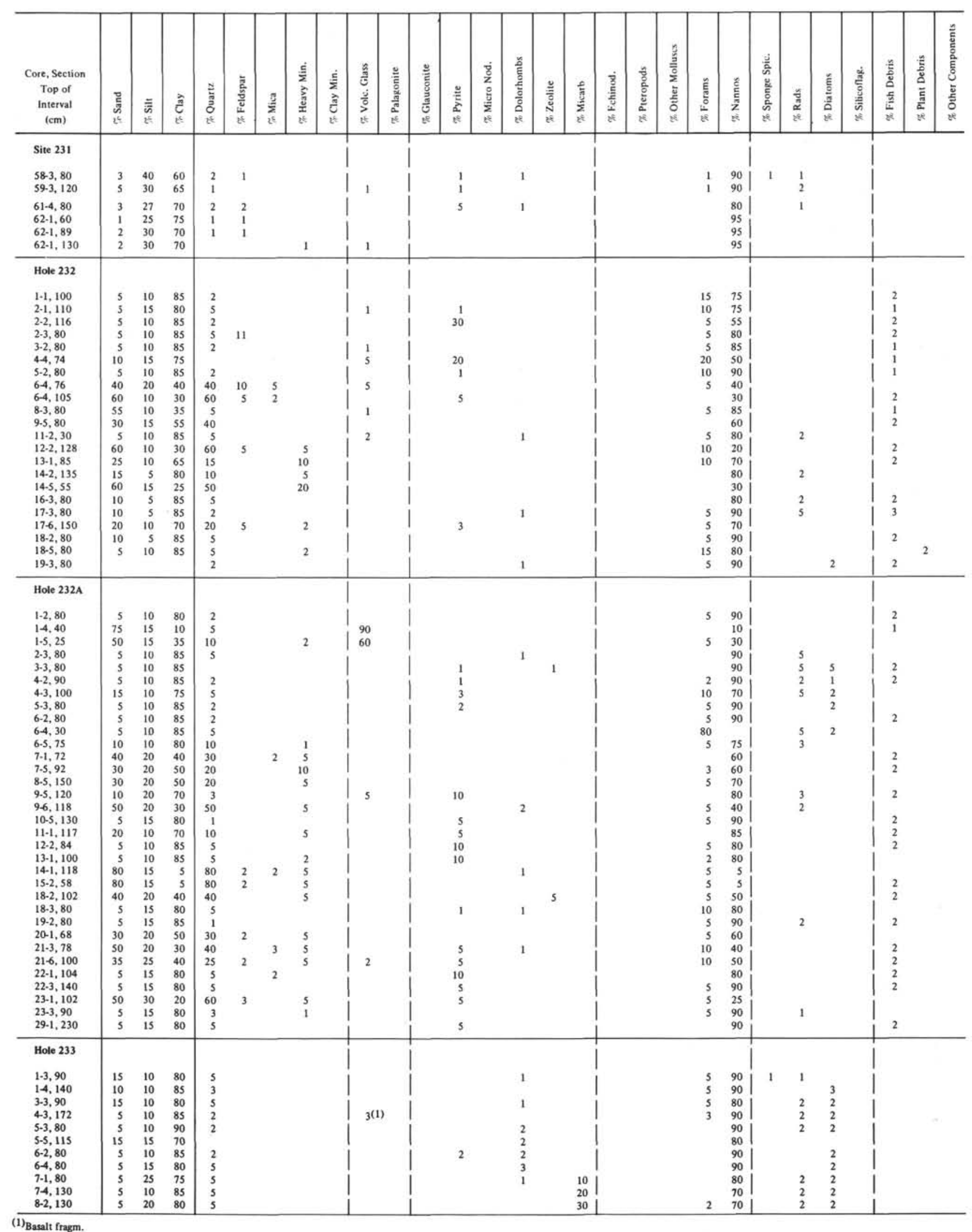




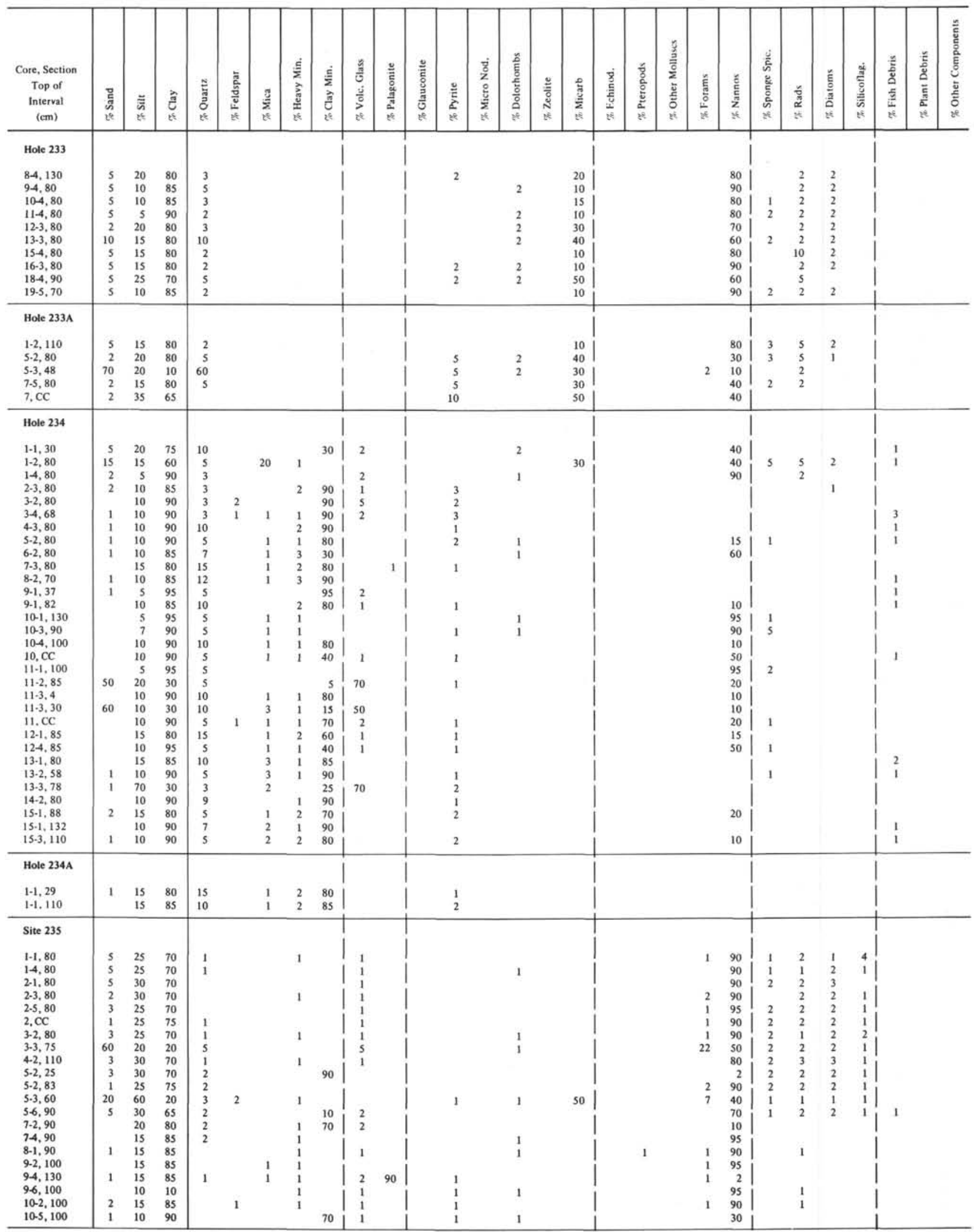




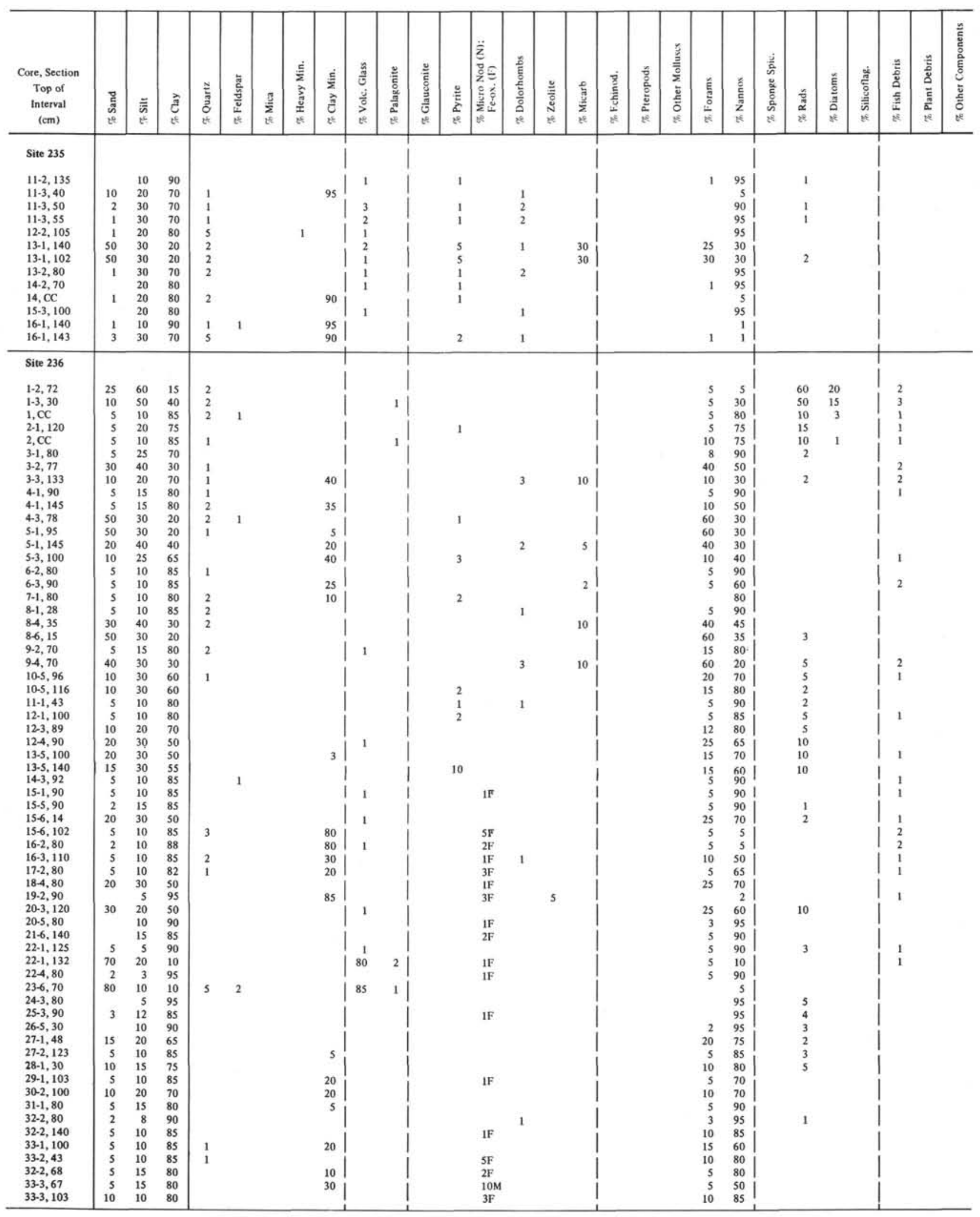




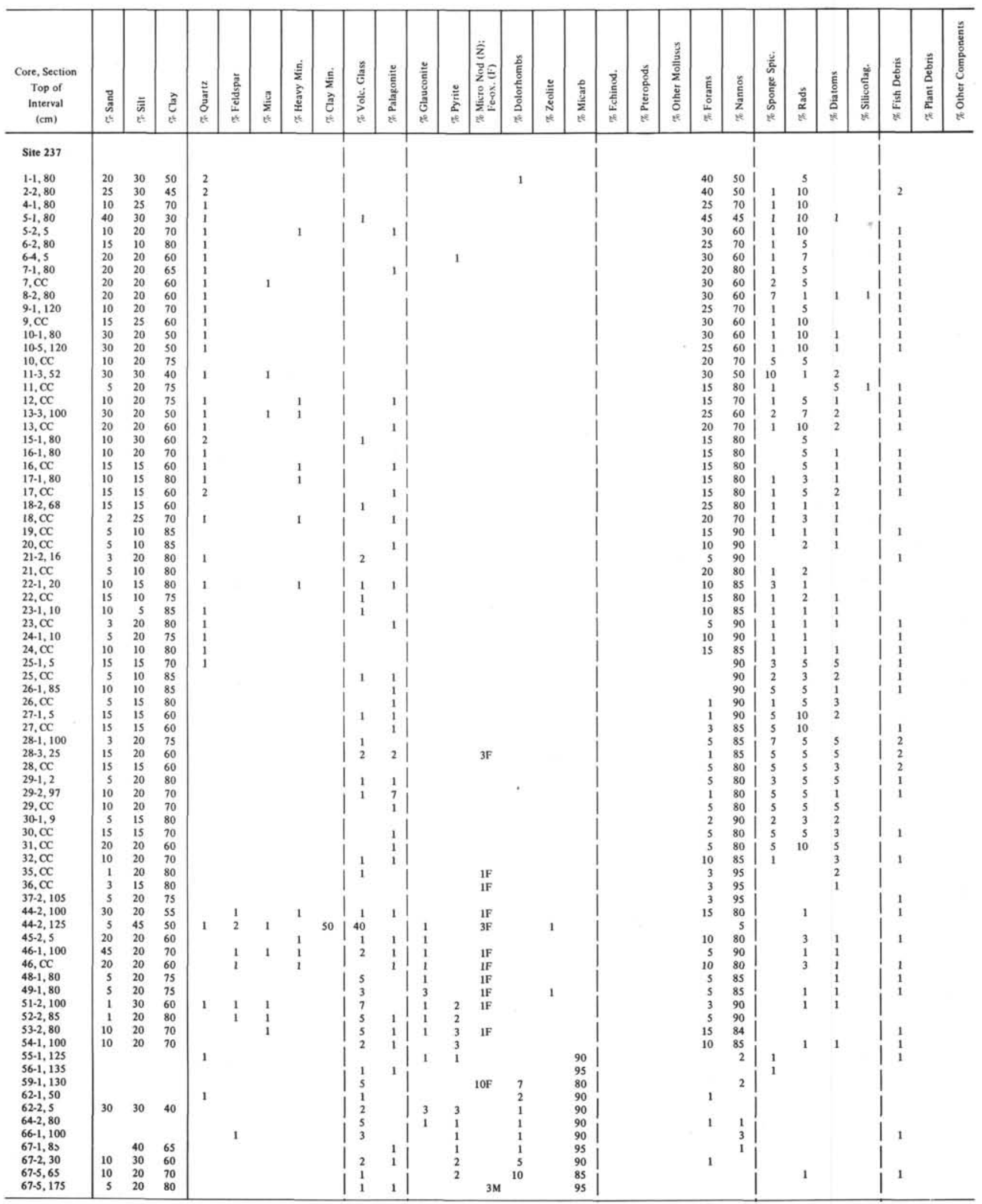




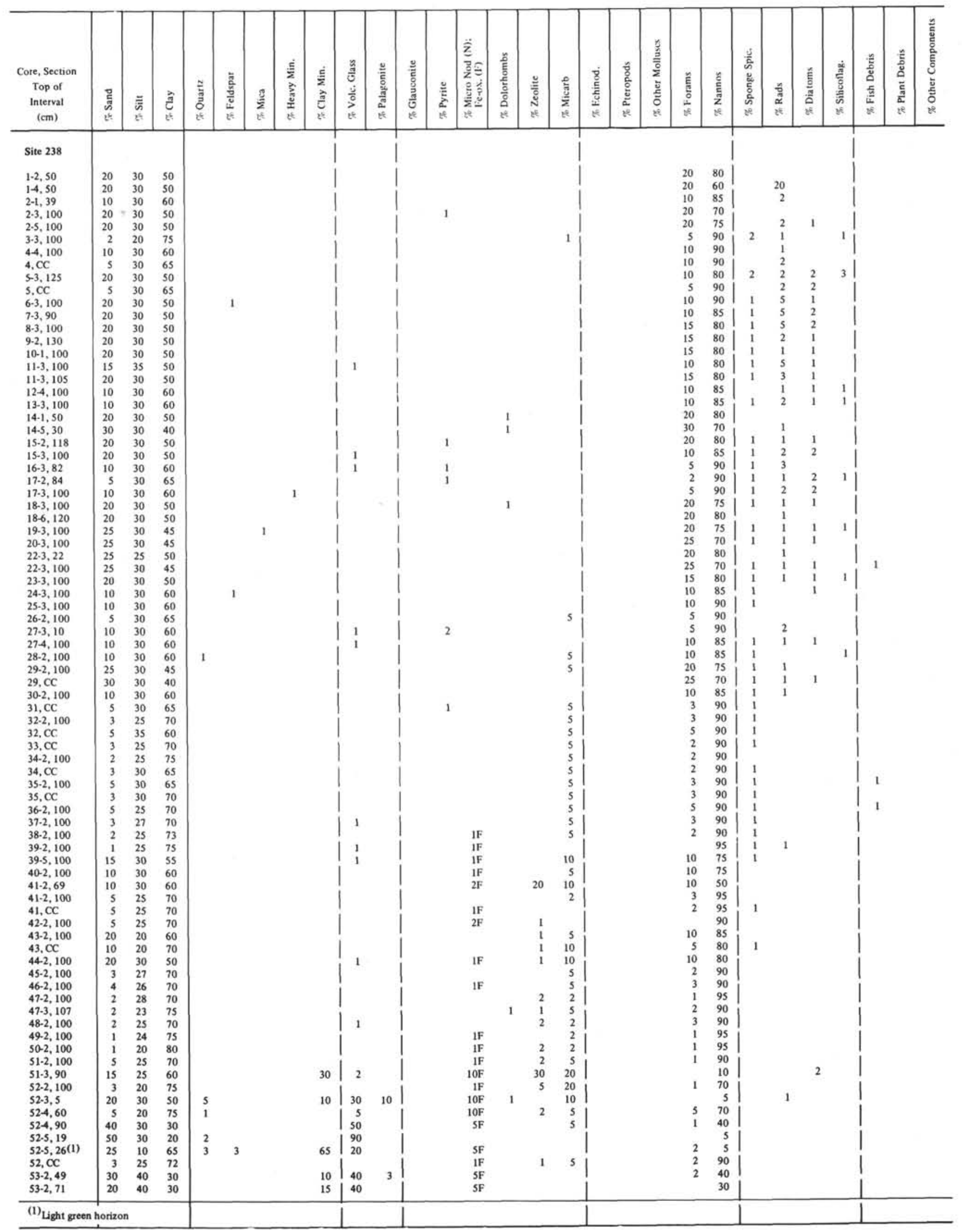




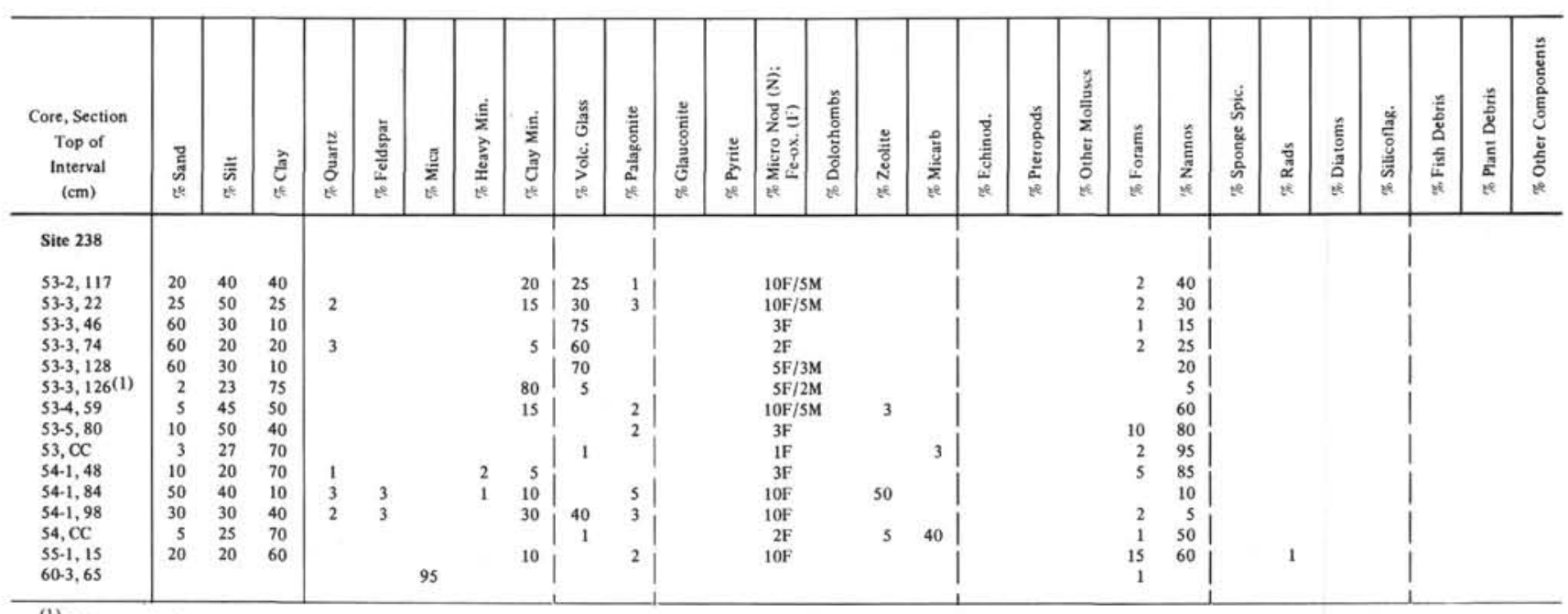

(1) Light green horizon

Note: Analyses were made by shipboard sedimentologists D. J. Cronan, V. V. Damiani, D. J. J. Kinsman, and J. Thiede, Grain-size, carbon-carbonate, and X-ray mineralogy data can be found in Appendix I. II, and Chapter 18; this volume, respectively. 